\author{
UNIVERSIDADE DE SÃO PAULO \\ ESCOLA DE ARTES, CIÊNCIAS E HUMANIDADES \\ PROGRAMA DE PÓS-GRADUAÇÃO EM MUDANÇA SOCIAL E PARTICIPAÇÃO \\ POLÍTICA
}

MICHELLE BORGES MIRANDA

Mais do que rua, camisinha e gel: TransCidadania, a experiência de um programa para travestis e transexuais na cidade de São Paulo.

São Paulo

2018 
MICHELLE BORGES MIRANDA

\title{
Mais do que rua, camisinha e gel: TransCidadania, a experiência de um programa para travestis e transexuais na cidade de São Paulo.
}

\author{
Versão Corrigida
}

Dissertação apresentada à Escola de Artes, Ciências e Humanidades da Universidade de São Paulo para obtenção do título de Mestre em Ciências pelo Programa de Pós-graduação em Mudança Social e Participação Política.

Versão corrigida Contendo as alterações solicitadas pela comissão julgadora no dia 22 de novembro de 2018. A versão original encontra-se em acervo reservado na Biblioteca da EACH/USP e na Biblioteca Digital de Teses e Dissertações da USP (BDTD), de acordo com a Resolução CoPGr 6018, de 13 de outubro de 2011.

Área de Concentração:

Governo Aberto e Participação Política

Orientador:

Prof. Dr. Jorge Alberto Machado

Co-orientador:

Prof. Dra. Elizabete Franco Cruz

São Paulo 
Autorizo a reprodução e divulgação total ou parcial deste trabalho, por qualquer meio convencional ou eletrônico, para fins de estudo e pesquisa, desde que citada a fonte.

\section{CATALOGAÇÃO-NA-PUBLICAÇÃO \\ (Universidade de São Paulo. Escola de Artes, Ciências e Humanidades. Biblioteca) CRB 8 - 4936}

Miranda, Michelle Borges

Mais do que rua, camisinha e gel: TransCidadania, a experiência de um programa para travestis e transexuais na cidade de São Paulo / Michelle Borges Miranda ; orientador, Jorge Alberto Machado ; coorientadora, Elizabete Franco Cruz. - 2018 $186 \mathrm{f}$. : il.

Dissertação (Mestrado em Ciências) - Programa de PósGraduação em Mudança Social e Participação Política, Escola de Artes, Ciências e Humanidades, Universidade de São Paulo Versão corrigida

1. Políticas públicas - São Paulo (SP). 2. Direitos sociais - São Paulo (SP). 3. Travestis. 4. Transexualidade. I. Machado, Jorge Alberto, orient. II. Cruz, Elizabete Franco, coorient. III. Título

$$
\text { CDD 22.ed. - } 320.60981611
$$




\section{FOLHA DE APROVAÇÃO}

MIRANDA, Michelle Borges

Mais do que rua, camisinha e gel: TransCidadania, a experiência de um programa para travestis e transexuais na Cidade de São Paulo.

Dissertação apresentada à Escola de Artes, Ciências e Humanidades da Universidade de São Paulo para obtenção do título de Mestre em Ciências do Programa de Pós-Graduação em Mudança Social e Participação Política.

Área de Concentração:

Governo Aberto e Participação Política

Aprovado em: 22 / 11 / 2018.

\section{Banca Examinadora}

Prof. Dra. Claudia Pereira Vianna

Julgamento: Aprovada

Prof. Dra. Vivian Grace Fernandez Davila Urquidi

Julgamento: Aprovada

Prof. Dra. Cláudia Maria Ribeiro

Julgamento: Aprovada
Instituição: FE -USP

Assinatura:

Instituição: $\quad$ EACH-USP

Assinatura:

Instituição: UFLA - Externo

Assinatura: 


\section{DEDICATÓRIA}

Bianca, Sasha Sasá, Dandara, Matheusa e tantas outras pessoas. À travestis, transexuais e não binárias que não tiveram a oportunidade de viver e ser elas mesmas sem que isso custasse suas vidas. Dedico este trabalho a todas elas que me motivam a resistir e acreditar que dias melhores virão. 


\section{AGRADECIMENTOS}

Eu não teria conseguido terminar esse trabalho sem o amor, apoio e carinho de diversas pessoas ligadas ou não a esse caminho do mestrado.

Nomear cada uma delas seria o mínimo a se fazer dado toda gratidão que sinto.

Entretanto, isso não seria factível nesse trabalho.

Ainda sim quero agradece-las de maneira subjetiva... Minha família, minhas amigas(os), meus amores, meus colegas de faculdade e de trabalho, todes, que sempre conseguiam me incentivar, a fim de que eu nunca desistisse desse caminho.

Eu amo cada um vocês e serei sempre imensamente grata, em especial:

Minha mãe Eunice Borges e meu pai Manoel Baldez, pela vida e amor incondicional; Meu orientador Dr $^{\circ}$ Profo $^{\circ}$ Livre Docente Jorge Alberto Machado por confiar em mim e pela amizade sincera;

Minha co-orientadora Elizabeth Cruz pela orientação, carinho e cuidado comigo;

À Symmy Larrat, pela confiança, amizade e carinho;

Todas as pessoas participantes do programa TransCidadania pela acolhida, em especial ao Luciano, Felipe, Amanda, Milena, Ariel, Aline, Christiane que me permitiram escutar e contar suas histórias;

À Clelia Prestes que com força, dedicação, profissionalismo e carinho me ajudou a me manter viva para viver esse momento;

À Sueli Feliziani, minha amiga, meu amor e minha revisora. Que teve paciência e tratou com tanto carinho este trabalho.

Obrigada a todes. 
"Tenho em mim todos os sonhos do mundo". Álvaro de Campos, 15-1-1928 


\section{RESUMO}

MIRANDA, Michelle Borges. Mais do que rua, camisinha e gel: TransCidadania, a experiência de um programa para travestis e transexuais na Cidade de São Paulo. 2018. 186 f. Dissertação (Mestrado em Ciências) - Escola de Artes, Ciências e Humanidades, Universidade de São Paulo, São Paulo, 2018. Versão corrigida.

A literatura sobre direitos humanos nos sugere que todas as pessoas estão protegidas pelos direitos como o de ir e vir, o direito à educação, à moradia, segurança, o direito a um nome, e o direito à saúde. O histórico de conquistas de direitos individuais e sociais no Brasil, segundo grandes autores como por exemplo Chauí (1984), Coutinho (1999) e Benevides (1994), mostra que os setores que não se sentem protegidos pelas convenções e tratados internacionais, saem em luta e defesa de direitos que configuram conquistas também para outros grupos marginalizados. Esta extensão, no entanto, não parece atender pessoas Trans ${ }^{* 1}$, em especial Travestis e Transexuais, que, de acordo com a Transgender Europe, são as maiores vítimas de homicídio no Brasil, e, consequentemente, um dos grupos com menor acesso a políticas públicas. Neste trabalho descrevo e analiso o programa TransCidadania, que surge como tentativa de resposta a esse quadro. Foram analisados os ciclos do programa de acordo com o Ciclo de Políticas Públicas de Mainardes (2001, 2006) em todas as etapas, a criação do programa, a sua implementação. Foram também avaliados seus objetivos e sucessos através dos documentos oficias do programa e balanços cedidos pela Secretaria Municipal de Direitos Humanos e Cidadania e da Coordenação do TransCidadania, analisei os discursos dos gestores e beneficiárias(os) do programa por meio de entrevistas semi-estruturadas. Como resultado desse processo de investigação reflito a partir de olhares de pesquisadores como Foucault (1988), Butler (2003), Bento (2014) e Pelucio (2007) sobre educação, violência física, empregabilidade, conjuntura política, indicadores que se destacaram nas entrevistas, através do mapa temático realizado. E foram levantadas algumas sugestões e impressões colhidas ao longo de todo o processo de investigação do programa TransCidadania.

Palavras-chave: Direitos Sociais. Políticas Públicas. TransCidadania. Travestis. Transexuais.

\footnotetext{
1 De acordo com Jesus (2012): "Conceito "guarda-chuva" que abrange o grupo diversificado de pessoas que não se identificam, em graus diferentes, com o gênero que lhes foi determinado quando de seu nascimento."
} 


\begin{abstract}
MIRANDA, Michelle Borges. More than street, condom and gel: TransCidadania, the experience of a program for transvestites and transsexuals in the City of São Paulo. 2018. 186 p. Dissertation (Master of Science) - School of Arts, Sciences and Humanities, University of São Paulo, São Paulo, 2018. Corrected version.
\end{abstract}

The literature on human rights suggests that we all are protected by rights such as the right to education, housing, security, the right to a name and to have healthcare. The history of achievements of individual and social rights in Brazil, according great authors such as Chauí (1984), Coutinho (1999) and Benevides (1994), shows that social sectors non-protected by the conventions and international treaties had struggling and advocacing for rights and their achievements can be sometimes extended for other marginalized groups. This extension, however, doesn't seem to meet Trans * groups, especially transvestites and transsexuals, which, according to the Transgender Europe, are the biggest victims of LGBTQI homicide in Brazil, and, consequently, one of the groups with less access to public policies and human rights. In this dissertation we describe and analyze the program TransCidadania, which appears to be an attempt to respond to this situation. The programm cycles were analyzed according to the Public Policy Cycle by Mainardes $(2001,2006)$ at all stages: since the creation of the program, it's implementation an results. Were also evaluated their goals and successes through the official program documents and result sheets provided by the Municipal Secretariat of human rights and citizenship and of the coordination of the TransCidadania. We analyzed also the speech of coordinators and beneficiaries (the) on the program by semi-structured interviews. In this investigation we can find perspectives of researchers like Foucault (1988), Butler (2003), Bento (2014) and Pelúcio (2007) on education, physical violence, employability, political context, indicators highlighted in the interviews, through the thematic map. We also raised some suggestions and impressions taken throughout the process.

Keywords: Social rights. Public Policies. TransCidadania. Transvestites. Transexuals 


\section{LISTA DE ILUSTRAÇÕES}

FIGURA 1 RELAÇÃO POR REGIÃO DE NASCIMENTO DAS PESSOAS PARTICIPANTES DO TRANSCIDADANIA.

FIGURA 2 - FLUXOGRAMA DO FUNCIONAMENTO DA ENTRADA DAS PESSOAS PARTICIPANTES NO TRANSCIDADANIA.

FIGURA 3 - FLUXOGRAMA DAS ATIVIDADES ESCOLARES E ACOMPANHAMENTO PEDAGÓGICOS.

FIGURA 4 - BALANÇO DA SÉRIE QUE AS PESSOAS PARTICIPANTES PARARAM OS ESTUDOS ANTES DE INGRESSAREM NO PROGRAMA.

FIGURA 5 BALANÇO ENTRE EVASÃO ESCOLAR E IDADE DAS PESSOAS

PARTICIPANTES ANTES DE INGRESSAREM NO PROGRAMA.

FIGURA 6 GRÁFICO SOBRE EVOLUÇÃO ESCOLAR DAS PARTICIPANTES 


\section{LISTA DE QUADROS}

Quadro 1- Eixos e ações do programa TransCidadania 


\section{LISTA DE SIGLAS E ABREVIATURAS}

ADIN - Ação Direta de Inconstitucionalidade

ANTRA - Associação Nacional de Travestis e Transexuais

APA - Associação de Psiquiatria Norte-Americana

APOGLBT - Associação da Parada do Orgulho LGBT

ATA - Assessoria Técnica e de Planejamento

BSH - Brasil Sem Homofobia

CADS - Coordenadoria da Diversidade Sexual

CADS - Coordenadoria de Assuntos de Diversidade Sexual

CAPS - Centro de Atenção Psicossocial

$\mathrm{CCH}$ - Centro de Referência em Direitos Humanos na Prevenção e Combate à Homofobia

CCLGBT - Centro de Cidadania LGBT

$\mathrm{CDDPH}$ - Conselho de Defesa dos Direitos da Pessoa Humana

CEP - Conselho Federal de Psicologia

CID - Classificação Internacional de Doenças

CIEJA - Centros de Acolhida, Centro Integrado de Educação de Jovens e Adultos

CME - Conselho Municipal de Educação

CNJ - Conselho Nacional de Justiça

Conasp - Conselho Nacional de Segurança Pública

CRM - Conselho Regional de medicina

CRT - Conselho Regional de Terapia

EJA - Educação de Jovens e Adultos

ENEM - Exame Nacional do Ensino Médio

FGTS - Fundo de Garantia por Tempo de Serviço

GEDS - Grupo de Estudos de Direitos e Sexualidade, da Faculdade de Direito da USP GLS - Gays, Lésbicas e Simpatizantes

GTI - Grupo de Terapia Integral

HIV - Vírus da imunodeficiência humana

IBGE - Instituto Brasileiro de Geografia e Estatística

LGBT - Lésbicas, Gays, Bissexuais, Travestis, Transexuais e Transgêneros.

LGBTQIA - Lésbicas, Gays, Bissexuais, Travestis, Transexuais, Transgêneros, Queer, Intersexo e A-genero 
OMS - Organização Mundial da Saúde

ONU - Organização das Nações Unidas

PIA - Plano Individual de Atendimento

PIB - Produto Interno Bruto

PLC - Projeto de lei da Câmara

PNDH - Plano Nacional de Desenvolvimento Humano

PNEDH - Plano Nacional de Educação em Direitos Humanos

POT - Programa Operação Trabalho

PRONATEC - Programa Nacional de Acesso ao Ensino Técnico e Emprego

PRRC - Projeto de Retificação de Registro Civil

PT - Partido dos Trabalhadores

SAE - Sistematização da Assistência de Enfermagem

SHD - Secretaria especial de Direitos Humanos

SMDHC - Secretaria Municipal de Direitos Humanos e Cidadania

SMDTE - Secretaria Municipal do Desenvolvimento, Trabalho e Empreendedorismo

SME - Secretaria Municipal de Educação

STF - Supremo Tribunal Federal

SUS - Sistema Único de Saúde

TGEU - Transgender Europe

UBS - Unidade Básica de Saúde 


\section{SUMÁRIO}

1.1 Caminhos Metodológicos

1.1.1 Análise documental: documentos oficiais e não oficiais sobre o programa Transcidadania.

1.1.2 Observação participante: dos processos e etapas, bem como de atividades do programa em sua sede.

1.1.3 Entrevistas: Mapa temático das entrevistas com gestores e pessoas

participantes do programa

2 UMA BREVE DISCUSSÃO SOBRE GÊNERO, SEXO E SEXUALIDADES

2.1 Norma e contranorma: "o quê" e "por quê" do gênero

2.3 Rubin: a opressão da mulher na divisão do gênero na sociedade

2.3.1. Rubin e o tráfico de mulheres

2.3.2 Pensando o sexo: Rubin e as políticas de controle da sexualidade e do gênero

2.4 Scott: gênero como categoria analítica relacional

2.5 Nicholson contra o fundamentalismo de gênero.

2.6 Butler e o gênero como performance

2.7 Diversidade feita carne: conceitos a respeito de travestilidade e transexualidade. 
3.1 Um breve histórico do movimento de travestis e transexuais no Brasil. 46

3.2 Cidadania e direitos sociais no Brasil

3.3 Definindo direitos e igualdade

3.4 Ordenações da ONU para os membros das Nações Unidas

3.5 Direitos humanos no Brasil: Da ditadura aos Planos Nacionais de Direitos Humanos

3.6 Do Nacional para o Municipal: São Paulo entra para o Raibow Cities Network

4.5. Na trilha da cidadania: passos da luta trans* nos 3 poderes

5.2.1. TransCidadania: um programa Trans*.

5.2.3 Transversalidade, educação e cooperação: formação para atendimento amplo e respeitoso à pessoa *trans 
5.4. Retratos do cotidiano do programa TransCidadania.

5.4.1 Quem são os atendidos nos programas? 93

5.4.2 Quais os tipos de Atendimento do Programa? 95

5.4.3 Educação para a cidadania 101

5.4.4 Acesso a direitos básicos: moradia, saúde e identidade 102

5.5 Os resultados do programa segundo balanço oficial do TransCidadania. 105

6 SOB UM NOVO OLHAR: AS ENTREVISTAS

6.1. O cotidiano e os encontros de um programa pioneiro: Algumas observações. 114

6.2. Para além de indicadores: Análise das entrevistas.

6.2.1 Violência

6.2.2 Educação

6.2.3 Empregabilidade

6.2.4 Direitos, Cidadania e Conjuntura Política

\section{CONSIDERAÇÕES FINAIS}

7.1 Transcidadadia e o Ciclo de Políticas Públicas de Ball

7.1.1 Contexto de Influência: discussão, contexto e demandas 139

7.1.2 Contexto produção de texto: $\quad 140$

7.1.3 Contexto de Prática: Lançamento, escolha dos atores. 140

7.1.4 Contexto de Estratégia Política: avaliação, criação de demandas, recriação 141

7.1.5 Contexto de Resultados: Estatísticas, mas principalmente efeitos e avaliação dos participantes

7.2 Balanço geral dos dois anos

7.3 Relatos e entrevistas

7.4 Novas Questões e avaliação geral

APÊNDICE A: LINKS UTEIS

APÊNDICE B: MAPA TEMÁTICO - ENTREVISTAS COM AS PESSOAS

PARTICIPANTES DO PROGRAMA TRANSCIDADANIA 01 


\section{APRESENTAÇÃO}

Quando me interessei por estudar as políticas públicas voltadas para travestis e transexuais no final do ano de 2014, já compreendia - através de estudos, reportagens, militância e da convivência diária com pessoas LGBTQIA2. - que o cenário dos direitos para essa população era marcado por negligência e violência.

O contexto político brasileiro durante o governo Lula 2003 - 2010 foi um período de tímidas tentativas de organização de políticas para LGBTQIA. O Programa Brasil Sem Homofobia lançado em 2004 mostrava que a pauta LGBTQIA havia ganhado espaço e força dentro da agenda pública. Por outro lado, a não aprovação do projeto de lei PLC122 de criminalização da homofobia ainda mostrava o longo caminho por direitos para a população LGBTQIA em geral.

Em 2011 a Presidente Dilma Rousseff vetou o Kit escolar Escola sem homofobia que pretendia debater com os estudantes assuntos sobre diversidade sexual e homofobia. E, durante o segundo mandato do Governo Dilma Roussef em 2015, travestis e transexuais foram incorporadas na Lei Maria da Penha (11.340/06), lei que protege mulheres vítimas de violência doméstica. No mesmo ano foi criado o Ministério das Mulheres, Igualdade Racial e Direitos Humanos, unindo as Secretarias de Políticas para Mulheres, de Políticas de Promoção da Igualdade Racial e a de Direitos Humanos. Posteriormente, este ministério foi extinto e incorporado como pasta no Ministério de Justiça e Cidadania, criado por Michel Temer, após assumir a presidência da República através de um golpe em 2016. Em 2017, houve novamente um remanejamento, com a criação do Ministério de Direitos Humanos, ainda sob a gestão de Michel Temer.

Pra os fins deste trabalho, utilizaremos a sigla LGBTQIA (Lésbicas, Gays, Bissexuais, Transexuais, Queers, Intersexo, Agêneros) para designar os movimentos, instituições, pessoas e demandas por diversidade gênero e sexualidade. 
O Brasil havia terminado o ano de 2014 como o país no topo do ranking de homicídios de travestis e transexuais no mundo, de acordo com os dados da Transgender Europe, associação internacional que coleta dados sobre violência a pessoas trans*. Apenas no mês de janeiro de 2015, os suicídios e assassinatos de transexuais por motivos transfóbicos atingiram a metade dos números contabilizados no ano de 2014 . O movimento LGBTQIA decidiu, então, que o tema do orgulho LGBTQIA em São Paulo seria a lei João Nery, pelo direito à identidade de gênero. Neste cenário, como uma tentativa de resposta às demandas LGBTQIA - mais especificamente a população trans* - nasce em São Paulo em 2015 o programa de reinserção social de travestis e transexuais em vulnerabilidade social: o TransCidadania.

Minha curiosidade em compreender o programa nasceu das tantas matérias divulgadas em jornais e mídias de grande difusão sobre o projeto. Céleres artigos e resenhas, blogs LGBTQIA, blogs e sites de partidos, organizações de esquerda e direita, antes mesmo da implementação do programa, muitas pessoas, de acordo com o que o jornalista e pesquisador Nelson Neto relata no livro Transcidadania: Práticas e trajetórias de um Programa Transformador, (2017), era comum comentar ou divulgar dados incompletos sobre o programa - apelidado por muitos como "bolsa travestis" o que não permitia perceber o alcance das ações que o programa estava propondo para além da transferência de renda.

Quando me aproximei ao TransCidadania para entender melhor seu funcionamento, procurei analisá-lo sob um olhar crítico. A pergunta "Como se deu o processo de criação e implementação do programa TransCidadania.?" induziu minha curiosidade sobre uma política até então pioneira em São Paulo.

A aproximação com o programa me trouxe diversos sentimentos e suscitou percepções até então não usuais como: o entendimento de que confiança seria pilar fundamental do desenvolvimento do trabalho; o medo de invadir a privacidade das pessoas participantes; medo de que se recusassem participar do trabalho por se sentirem objetos de estudo e não sujeitos em um programa analisado; o olhar duvidoso que pudessem ter em relação aos acadêmicos. Porém, também ao longo do trabalho, pude receber o conforto encorajamento de colegas, orientadores, e envolvidos, que me deram segurança para tomar os passos necessários com a calma requerida. 
Durante o processo de mestrado, a principal pressão não foi o tempo ou os créditos obrigatórios, nem mesmo a vaidade pelas primeiras publicações científicas sobre o programa. A principal pressão foi a angústia que sentia pelas estatísticas ainda crescentes, que saltavam em portais de notícias sobre violência e morte de travestis e transexuais. Elas não apenas evidenciavam a necessidade de programas de cidadania e segurança efetivos para essa população como apontavam o medo constante de perder alguém conhecido do programa. $E$ com isso a pergunta sempre voltava a cabeça: "O programa seria capaz de cumprir seus objetivos? Por quanto tempo?" E, com o passar do tempo, fui elaborando outras, tão importantes quanto: "Como se dará a vida das pessoas participantes durante o programa? E depois?".

Curiosamente, o tempo de vigência do programa inicial de dois anos era exatamente meu prazo de trabalho da dissertação que, assim como o programa, estava em processo de construção. O programa TransCidadania, de acordo com as entrevistas com Alessandro Melchior3, Symmy Larrat4 e da minha observação, nasceu de uma necessidade da população trans* ${ }^{*}$ da vontade dos servidores da Prefeitura de São Paulo envolvidos na Secretária de Direitos Humanos e Cidadania, e, principalmente, do interesse do então prefeito, Fernando Haddad, a fim de atender uma reivindicação do Movimento trans*, mas também de promover e garantir os direitos fundamentais sociais das pessoas trans* ${ }^{*}$ direitos necessários para se pensar na construção de um estado social democrático de direitos.

O TransCidadania foi ganhando forma à medida que ia sendo implementado, corrigindo caminhos, melhorando os aspectos bem-sucedidos, absorvendo críticas como, por exemplo, a localização central que dificultava a participação de pessoas Trans* residentes das demais zonas da cidade (Oeste, Norte, Sul e Leste).

O que poderia ser uma sinalização de novos tempos nas políticas públicas para a população trans* no Brasil, com a conscientização e debate sobre a importância de políticas para esse setor, se viu, entretanto, - assim como várias outras áreas barrada por uma mudança da conjuntura política brasileira.

${ }^{3}$ Coordenador de Políticas LGBT da Secretaria Municipal de Direitos Humanos e Cidadania de São Paulo, durante os anos de $2015-2016$.

${ }^{4}$ Coordenadora do Programa TransCidadania durante 2015 e 2016. 
Em 2016, quando o programa celebrava suas vitórias e se preparava para o desafio de ampliação para 200 pessoas participantes, o país entrou em processo de impeachment de sua presidenta e instabilidade era a palavra do momento. Neste cenário era pessoalmente desafiante lidar com a constante instabilidade do objeto estudado e como isso afetava as análises a serem realizadas.

Quando realizei minhas entrevistas no meio de 2016, não houve sequer uma entrevistada que não temesse pelo retrocesso não apenas do TransCidadania, mas das políticas LGBTQIA como um todo. O final de um ciclo do programa TransCidadania estava se encerrando, haviam muitas conquistas a se comemorar, mas também haviam muitas questões a se pensar, não apenas sobre as pessoas participantes que entravam no programa, mas também sobre as que saíram, principalmente aquelas que não conseguiram alcançar todas as possibilidades que o programa poderia oferecer.

As informações oficiais e os resultados que obtive quando realizei a pesquisa contribuíram para o entendimento do panorama das políticas públicas para pessoas trans* no país, bem com o porquê das opções de caminhos pelos quais o programa TransCidadania decidiu trilhar. Mas, ao longo desses dois anos, minha principal fonte de informação sobre o efeito real do programa se deu em espaços de vivência das pessoas que participam do programa, com as quais criei afinidade, conhecendo suas casas, participando de momentos festivos - celebração de final de ano e casamento -, nas trocas de mensagens sobre preocupações do dia a dia com as pessoas que me permitiram conhecê-las para além do programa.

Pude acompanhar de perto as dificuldades dessa parcela da população e suas estratégias de sobrevivência. Acredito que o conjunto de procedimentos e as interações, tanto procedimentais quanto espontâneas, me permitiram ter uma visão geral e crítica do programa TransCidadania o suficiente para extrair as informações necessárias dos períodos de entrevistas e observação.

Hoje, enquanto finalizo a escrita deste trabalho e pesquiso novidades sobre 0 programa nas redes sociais, me deparo com notícias e fotos de movimentos LGBTQIA que começam a se articular reunindo-se com os novos gestores a fim de convencêlos da importância da continuidade do programa. É evidente a preocupação com as demais travestis e transexuais, as centenas que não tiveram oportunidade de passar pelo programa e que continuam sem acesso às políticas públicas, seus direitos mais básicos e sua efetiva cidadania. 
Por outro lado, consigo enxergar as oportunidades que homens e mulheres ganharam através do programa e seus resultados.

Gostaria de mencionar especialmente um último episódio do qual participei. O casamento de um ex-participante do programa: O choro dele por um sonho realizado, por todo o simbolismo que o casamento possa ter em seu imaginário, mas também pela emoção da vitória de chamado pelo padre por seu nome e ser reconhecido. Durante o casamento vi lágrimas e sorrisos, na festa havia celebração do amor, mas também do direito de ser reconhecido por sua identidade, que, naquele momento, ele alcançava.

Acredito que muito em breve este direito tão básico e tão ansiado será alcançado por todas as travestis e transexuais que o requererem. Isso não parece hoje fácil, mas é possível. Meu desejo é que este trabalho se some ao conjunto de iniciativas acadêmicas e ações de luta dos movimentos e ativistas LGBTQIA, e que contribua para este propósito: a cidadania plena. 


\section{INTRODUÇÃO}

"Você é travesti, você tá em situação de vulnerabilidade, é uma coisa assim, que não tem (Pausa para respiração)... Umas em mais e outras em menos... Eu estou nesse espaço, mas quando o TransCidadania acabar eu volto pra esquina, igual a todas elas. Até que ponto eu sou menos vulnerável que elas?" (Larrat, 2016).

A vulnerabilidade a que se refere a Coordenadora do programa TransCidadania Symmy Larrat em sua fala é a precariedade social em que travestis e transexuais estão expostas pelo preconceito, violência e pela ausência de políticas públicas contínuas que atendam a população trans* (Travestis, transexuais, transgêneros) em suas demandas específicas, como acesso à educação, saúde pública de qualidade, registro de nome sem burocracia, atendimento de saúde especializado. Pois, como mencionam Bento e Pelucio (2012, p. 487) "[...] travestis permanecem invisíveis e silenciadas nas políticas públicas de acesso à seguridade social e cidadania, mas estrategicamente visíveis na argumentação sobre tráfico e exploração".

Segundo o relatório Transrespeito versus Transfobia de 2014 e 2015 da Transgender Europe $^{5}$, o Brasil é o país com o maior número de homicídios de pessoas trans* no mundo, vítimas de transfobia ${ }^{6}$. Esses dados, entretanto, estão longe de refletir a realidade - que é bem mais assustadora -, quando consideramos os dados não oficias que, segundo a associação de defesa dos direitos humanos dos homossexuais no Brasil, chamada Grupo Gay da Bahia7, os dados são maiores do que o registrado pelos órgãos oficiais devido ao não reconhecimento e tipificação dos casos como homofobia, transfobia e lesbofobia.

${ }^{5} \mathrm{O}$ Transgender Europe é uma rede internacional de diversas organizações de pessoas transgêneros, que visam combinar ações e combater a discriminação por transfobia. http://tgeu.org/ link para relatório http://transrespect.org/wp-content/uploads/2015/08/TVT_research-report_ES_.pdf

${ }^{6}$ Trata-se da discriminação, violência ou repugnância contra uma pessoa transgênero.

${ }^{7}$ Grupo Gay da Bahia é a mais antiga associação no Brasil em defesa dos direitos humanos de homossexuais, localizada em Salvador-BA. http://www.ggb.org.br/welcome.html 
Para Bento e Pelúcio (2012, p.569), "apesar das mudanças políticas e sociais em relação às transexualidades e travestilidades, estas ainda são consideradas pela Associação de Psiquiatria Norte-Americana (APA) e pela Organização Mundial da Saúde (OMS) transtornos do comportamento sexual" ${ }^{8}$. A indicação de um aspecto da diversidade de gênero no Catálogo Internacional de doenças tornou a luta por políticas públicas para pessoas trans* ainda mais difícil, e a cura do "transtorno" passaria pela readequação de gênero e não pela eliminação dos desafios psicológicos e mentais causados pela transfobia, pela violência estrutural, e pela disforia. E esta situação era agravada pela insistência de grande parte de gestores em não entender a necessidade de investir em políticas para uma parcela da sociedade que permanece "invisível”. Isto muda agora em 2018 com a identificação dos transtornos de identidade de gênero como transtornos da identidade sexual, colocando o sofrimento mental e a disforia como sintomas a serem tratados, e não a condição de transexual, e tendo o bem-estar e a identificação correta de acordo com o gênero subjetivo e a sua construção como objetivos.

As políticas públicas para a população de travestis e transexuais no Brasil sofrem grande resistência, uma vez que grande parte do setor legislativo é composto de pessoas cisgênero9 ou comprometido com setores fundamentalistas e conservadores que, muitas vezes, protagonizam publicamente cenas reacionárias às pautas LGBTQIA, o que, na prática, impede que iniciativas como a lei PL122/200610 ou o material Escola sem Homofobia11 fossem efetivas.

A América Latina, de modo geral, após décadas de lutas e conquistas dos movimentos LGBTQIA de países do norte, motivados por conflitos como a Revolta de Stonewall em 1969, tem tido significado avanço em ações dos Estados e na aprovação de leis que buscam garantir direitos a estes setores da sociedade.

\footnotetext{
${ }^{8}$ No dia 18 de Junho de 2018, a Organização Mundial de Saúde (OMS) retirou a transexualidade da categoria de "distúrbios mentais" do Código internacional de Doenças (CID) e passou a considerar como incongruência de gênero.

${ }^{9}$ Cisgênero, ou apenas "cis", são pessoas que se conformam com a identidade de gênero determinada ao nascer. Transgêneros são pessoas que não se conformam com esta identidade, passando posteriormente por processos de transição de gênero.

10 Projeto de lei que visava criminalizar a homofobia. Link para o projeto de Lei arquivado em 2015. https://www25.senado.leg.br/web/atividade/materias/-/materia/79604

${ }_{11}$ Material escolar que visava garantir uma educação contra discriminação e preconceito a pessoas LGBTQIA e que foi apelidado de cartilha gay. http://acervo.novaescola.org.br/pdf/kit-gay-escola-sem-homofobia-mec.pdf
} 
A Argentina foi o primeiro país a legalizar o casamento entre pessoas do mesmo sexo, em 2010'2, direito este estendido para estrangeiros em algumas províncias, como Buenos Aires. Em 2012 foi celebrada a lei de igualdade de gênero' ${ }^{13}$, considerada uma das mais modernas no mundo, pois garante à pessoa trans ${ }^{*} \mathrm{o}$ direito de alterar de maneira gratuita toda sua documentação, sem precisar submeter-se a qualquer diagnóstico físico ou psicológico, o que, no Brasil, só foi garantido em Março de 2018 com a decisão do Supremo Tribunal Federal - STF (ISP, 2015) a respeito de retificação em cartórios sem necessidade de laudos médicos e comprovação.

No Uruguai o casamento entre pessoas do mesmo sexo também foi legalizado, dando aos casais os direitos comuns de saúde, previdência, adoção, entre outros que já estavam previstos para casais heterossexuais. Também aprovou o direito de gays servirem nas forças armadas, leis antidiscriminatórias no congresso, o direito de mudança de nome e gênero sem a necessidade de cirurgias e em 2011 ampliou para Travestis e Transexuais, o cartão Uruguai Social, do Ministério de Desenvolvimento Social ${ }^{14}$, dando a população trans* não só o benefício antes existente de bolsa alimentação, mas também a oportunidade de exercer uma atividade remunerada em órgãos públicos.

Outros países da América Latina também buscam a garantia de direitos na esfera legislativa. No Peru, foram aprovadas leis que criminalizam a discriminação de gênero. Alguns ainda discutem os direitos de pessoas LGBTQIA - como é o caso de Cuba e outros, como a Nicarágua, avança na descriminalização da homossexualidade. $\mathrm{O}$ México avança em leis antidiscriminatórias em nível federal e instituiu o dia nacional de combate à homofobia (ISP, 2015).

\footnotetext{
${ }^{12}$ Lei Nacional Argentina $\mathrm{N}^{\circ} 26.618$, com mudança na seção referente ao código civil, dos direitos a relações familiares e da sociedade conjugal.

${ }^{13}$ Lei n 26.743 estabelecida pelo decreto N 773/2012 do poder Executivo Nacional da Argentina no dia 24 de maio de 2012, que assegura a igualdade de gênero para pessoas transexuais.

14 Lei de transferência de renda para pessoas em condição social vulnerável no Uruguai. http://presidencia.gub.uy/comunicacion/comunicacionnoticias/tarjeta-uruguay-social-transproteccion-social Acessado em 4/04/2017.
} 
Ainda há inúmeros avanços a serem alcançados em relação à seguridade social e cidadania da população LGBTQIA, em especial de travestis e transexuais, em diversas dimensões de suas vidas públicas e privadas. A própria luta por esses avanços é, entretanto, reflexo de um processo histórico que envolve reivindicações, tratados, acordos e convenções internacionais - como as iniciativas da ONU em suas campanhas intituladas "Livres e Iguais"15- que visam a incorporação das demandas da população LGBTQIA na formulação de políticas públicas.

No Brasil, o governo federal, em especial a partir de 2004, tem se dado a tarefa de produzir documentos importantes quanto à discussão dos direitos humanos da comunidade LGBTQIA, como o Plano Nacional de Desenvolvimento Humano-3 (PNDH-3), as Conferências Nacionais de Políticas Públicas de LGBTQIA (2008, 2012 e 2016) - realizadas em Brasília para a comunidade discutir o conjunto de suas pautas com figuras governamentais. Porém, tais ações quando comparadas com a realidade de milhares de travestis e transexuais e com a comunidade LGBTQIA como um todo, demonstram a fragilidade das poucas políticas públicas até hoje implementadas.

De acordo com Mello (2012, p. 425) o Brasil vive um momento paradoxal em relação aos direitos humanos da LGBTQIA. Por um lado, tem se conquistado alguns direitos - como o respeito ao nome social - historicamente resguardados da diversidade por uma elite heteronormativa16 e aprofundando o debate público sobre a existência de outras formas de ser e se relacionar. Por outro lado, ainda existe a reação conservadora dessa mesma elite e sua pretensão de perpetuar o extermínio desses sujeitos e seus afetos.

15 No capítulo sobre direitos LGBTQIA, exploro com mais profundidade a cartilha e a campanha da ONU, "Livres e Iguais".

16 A heteronormatividade, de acordo com Petry e Meyer (2011), tem a função de "regular e normatizar modos de ser e de viver, os desejos corporais e a sexualidade de acordo com o que está socialmente estabelecido para as pessoas, numa perspectiva biologicista e determinista, há duas - e apenas duas - possibilidades de locação das pessoas quanto à anatomia sexual humana, ou seja, feminino/fêmea ou masculino/macho". 
Com o intuito de responder a algumas destas demandas históricas da população trans ${ }^{*}$ por direitos, resultado de encontros e reivindicações de movimentos sociais e LGBTQIA, em 2015 a Prefeitura de São Paulo lançou o programa TransCidadania. Ele foi criado através da Coordenadoria de Políticas LGBTQIA ligada à Secretaria Municipal de Direitos Humanos e Cidadania, e visa, de acordo com site 17 da Prefeitura de São Paulo, fortalecer as atividades de colocação profissional, reintegração social e efetivação da cidadania para travestis e transexuais em situação de maior vulnerabilidade.

O programa foi lançado através do Decreto $N^{0} 55.874$, de 29 de janeiro de 2015, dia de comemoração da visibilidade trans ${ }^{*}$ e prevê em seu escopo atividades de formação e capacitação para o mercado de trabalho junto a uma rede de parceiros como a Secretaria de Assistência Social, Secretaria de Educação, Secretaria de Trabalho, Secretaria de Assistência e Desenvolvimento Social, Secretaria de Saúde, Secretaria de Políticas para Mulheres, designando a transferência de renda através de um auxílio financeiro às pessoas participantes do programa por meio do Programa Operação Trabalho (POT18), visando não apenas auxiliar a formação educacional e profissional das pessoas participantes, mas também suas necessidades psicossociais.

O objetivo geral deste trabalho constitui-se em descrever e analisar o programa TransCidadania - um modelo experimental de política pública transversal. Para atingir os objetivos pretendidos, optou-se por realizar uma pesquisa qualitativa 19 e exploratória20. Em virtude disso, optei por utilizar um conjunto de procedimentos metodológicos 21 que possibilitasse liberdade às participantes para expressar seus sentimentos quanto ao objeto estudado, sem limitá-las aos questionamentos feitos pela pesquisadora.

\footnotetext{
17 Site da Prefeitura de São Paulo sobre o programa TransCidadania. http://www.prefeitura.sp.gov.br/cidade/secretarias/trabalho/cursos/operacao trabalho/index.php?p=170430

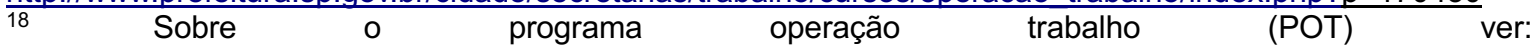
http://www.prefeitura.sp.gov.br/cidade/secretarias/trabalho/cursos/operacao trabalho/index.php?p=610 ${ }^{19}$ Para Knauth (2000), a pesquisa qualitativa "não têm qualquer utilidade na mensuração de fenômenos em grandes grupos, sendo útil para quem busca entender o contexto onde algum fenômeno ocorre. Sendo assim, ela permite a observação de vários elementos simultaneamente em um pequeno grupo. Essa abordagem é capaz de propiciar um conhecimento aprofundado de um evento, possibilitando a explicação de comportamentos."

20 A natureza exploratória de uma pesquisa ocorre quando o estudo envolve técnicas que buscam reunir informações preliminares das situações observadas, seja por meio de levantamento bibliográfico, entrevistas em profundidade, análise de dados secundários, entre outras. Esse conjunto de estratégias busca proporcionar maior conhecimento do objeto em estudo e do fenômeno em si e assim refinar as etapas seguintes (Marconi; Lakatos, 2008).

21 Para realizar esse trabalho busquei olhar também alguns procedimentos metodológicos antropológicos que me serviram de inspiração para o trabalho de campo.
} 


\subsection{Caminhos Metodológicos}

Este trabalho foi realizado em três etapas:

1.1.1 Análise documental: documentos oficiais e não oficiais sobre o programa Transcidadania.

Em todas essas etapas, as experiências foram registradas no diário de campo22, que, posteriormente, cumpriu o propósito de documentar o trabalho de campo e como fonte de dados para as análises realizadas.

A etapa (1) consiste de um procedimento metodológico que visa identificar informações ocorridas em documentos com base nas questões de interesse do trabalho (Lüdke \& André, 1986). Essas informações podem ou não serem complementares às informações obtidas por outras técnicas, revelando aspectos novos de um tema ou problema. Ela é realizada a partir de fontes como tabelas estatísticas, cartas, pareceres, fotografias, atas, relatórios, obras originais, notas, diários, projetos, leis, ofícios, discursos, mapas, testamentos, inventários, informativos, depoimentos orais ou escritos, certidões e outros documentos que podem estar arquivados em repartições públicas, associações, igrejas, hospitais, sindicatos (Santos, 2000).

Segundo Víctora, et al (2000) a análise de documento tem por vantagem:

a forma elaborada do conteúdo e o fato de, uma vez na nossa posse, o documento está disponível para análise. A seleção dos aspectos de interesse junto à fonte documental é mais rápida, garantindo maior controle e domínio por parte do pesquisador (Víctora et al., 2000, p. 72).

22 De acordo com Knauth (2000), o diário de campo tem por função registrar de forma cronológica toda a interação do pesquisador com seu trabalho, registrando observações, experiências e sentimentos. 
Deste modo, foram levantados e analisados materiais públicos relacionados ao programa, documentos oficiais cedidos pela Prefeitura de São Paulo através da Coordenadoria de Políticas LGBTQIA, tais como a Nota Conceitual, Termo de Compromisso do Programa, Decreto de Instauração do Programa, Deliberação do Conselho Municipal de Educação23 quanto aos direitos LGBTQIA e ao direito do uso do nome social nas escolas municipais, Plano Individual de Atendimento (PIA), Ficha de Frequência, livro lançado sobre o TransCidadania pela prefeitura e o balanço oficial do programa.

1.1.2 Observação participante: dos processos e etapas, bem como de atividades do programa em sua sede.

De acordo com Correia (1999, p.31) a observação participante (2) é o contato direto, frequente e prolongado do investigador com os atores sociais, constituindo uma técnica de investigação que usualmente se complementa com a entrevista semiestruturada ou livre e com outras técnicas de análise documental. $\mathrm{O}$ autor entende a técnica de observação participante como o trabalho de campo no seu conjunto, isso é, desde os primeiros contatos do pesquisador com o grupo de pesquisa, quando inicia as negociações, sua chegada, até a conclusão do trabalho.

Essa etapa deu-se na sede do programa TransCidadania e em atividades realizadas pelo programa com as pessoas participantes em espaços públicos da cidade de São Paulo, tais como: aulas públicas sobre direitos e cidadania na Câmara Municipal dos Vereadores São Paulo, aulas na sede do programa TransCidadania entre os meses de Março de 2015 e Dezembro de 2016, com turmas de ambos os anos, e em conversas espontâneas com as pessoas participantes no decorrer das atividades.

1.1.3 Entrevistas: mapa temático das entrevistas com gestores e pessoas participantes do programa.

23 Link para acesso a notícia e lei da deliberação do Conselho Municipal de Educação. http://portal.aprofem.com.br/leitura-conteudo/00000651 
Finalizada a observação (ainda que ela continuasse permeando todas as etapas seguintes), iniciei a etapa (3) de entrevistas semiestruturadas. Por causa do acompanhamento das atividades da turma de 2015 e o processo de ingresso das pessoas participantes de 2016, já me sentia segura para elaborar o quadro das possiveis participantes que fariam parte desta fase. As entrevistas foram feitas a partir de um roteiro previamente formulado, com base nos documentos analisados e nas conclusões tiradas a partir da observação participante. Estas entrevistas ocorreram no segundo semestre de 2016.

Para Triviños (1987, p.152), a entrevista semiestruturada “(...) favorece não só a descrição dos fenômenos sociais, mas também sua explicação e a compreensão de sua totalidade (...)" e, portanto, tende a ter a partir de questionamentos básicos, apoiados em teorias e hipóteses que se relacionam ao tema da pesquisa. Manzini (2003, p. 13) acrescenta que outras questões inerentes às circunstâncias momentâneas à entrevista podem ser complementadas às perguntas principais com o objetivo de fazer emergir informações de forma mais livre, sendo o roteiro, dessa forma, além de um instrumento de coleta de informações básicas, também um modo do pesquisador se organizar durante o processo de interação com o informante.

Foram realizadas 11 entrevistas semiestruturadas: seis pessoas ligadas a equipe do programa (coordenador de Políticas LGBTQIA, coordenadora do Programa TransCidadania, psicóloga do programa, assistente social do Programa, assistente de coordenação e auxiliar administrativa), sendo que destas, uma integrante da equipe também foi participante do TransCidadania. Entre as pessoas participantes, foram entrevistadas cinco pessoas travestis, homens e mulheres trans* ${ }^{*}$ buscando ao máximo abranger as duas turmas, as diferentes condições de moradia, níveis de escolaridade e tratamento psicossocial, formando assim um grupo heterogêneo de participantes.

Esses encontros se deram em dois blocos, às (1) entrevistas das pessoas participantes e as (2) entrevistas do corpo técnico. Elas foram realizadas ao longo do ano de 2016, na sede do programa TransCidadania de acordo com a agenda e disponibilidade dos gestores e das pessoas participantes. As perguntas giraram em torno da constituição do TransCidadania e a visão particular de cada entrevistado sobre o andamento e resultados do programa. 
O primeiro grupo a ser entrevistado foi composto pela equipe técnica. No início de cada entrevista, as pessoas participantes mencionaram suas funções e competência dentro do programa, além de responderem as questões levantadas tanto pelo questionário quanto as que surgiram ao longo da conversa. As entrevistas abordaram, principalmente, a descrição do programa a partir de suas perspectivas, limites, desafios e conquistas alcançadas. Os trechos extraídos dessas entrevistas foram utilizados de modo a validar e complementar o histórico e passos do programa.

As entrevistas com o segundo grupo, composto pelas pessoas participantes do programa, foram realizadas em dias distintos, devido ao horário de atividades do programa Transcidadania que cada uma executava. Nenhuma delas demonstrava se sentir desconfortável com a gravação, na realidade, o desconforto partia de mim, que temia ser invasiva. No total, as gravações desta etapa têm em torno de três horas.

A análise de documentos, a observação participante e as entrevistas somadas à revisão da literatura sobre o tema, serviram para ampliar a visão da pesquisa na análise dos resultados. $\mathrm{E}$, para tratar esse conjunto de informações, buscou-se uma ferramenta que pudesse integrar e relacionar informações e atribuir significado ao objeto estudado, assim, o mapa dialógico mostrou-se um recurso necessário por ser capaz de elucidar passos dados na construção da pesquisa.

De acordo com Okada (2014) apud Conklin (2006):

O mapa dialógico é a representação da discussão por meio de um conjunto de questões ou problemas, possíveis soluções, respostas, prós e contras, anotações, referências e conclusões ou decisões. A conversa é orientada e configurada pela visualização do próprio mapa que representa o diálogo" (p. 214)

O mapa dialógico foi construído com base na transcrição sequencial dos áudios obtidos nas entrevistas. A partir daí um mapa de síntese, ou mapa temático, foi elaborado, destacando os temas abordados em cada fala, sendo eles ligados ou não ao roteiro preestabelecido. Havia, entretanto, a necessidade da sistematização das falas a partir das perguntas do roteiro, para que fosse possível a análise das respostas às perguntas feitas pela pesquisadora. Por fim, o mapa resultante permitiu a visualização dos temas, principalmente em relação às metas do programa, como a educação (eixo central) e outros temas como: violência física, direitos e cidadania empregabilidade e conjuntura política. 
Sendo este trabalho uma pesquisa qualitativa e exploratória, os temas que compuseram o mapa temático foram identificados, também, ao longo das observações e análises de documentos e confirmados nas transcrições sequenciais das entrevistas realizadas e nos discursos analisados. O mapa permitiu sistematizar o processo de interpretação das entrevistas, estabelecer conexões entre as temáticas que emergiram durante as etapas da pesquisa e identificar as categorias dos objetivos analisados.

A pesquisa e os resultados foram divididos e estruturados em cinco capítulos ao longo deste trabalho da seguinte forma:

No segundo capítulo analiso um possível percurso dos conceitos de gênero ao longo da História, com autoras importantes como Beauvoir, Rubin, Scott e Nicholson. Juntamente com algumas aproximações a Foucault e Laqueaur salientando a perspectiva de gênero que adotamos neste trabalho, juntamente com relações importantes com conceitos como sexo, sexualidade, práticas sexuais, política e legalidade.

O terceiro capítulo aborda as noções de Diversidade, Cidadania, de Direitos. Ainda nesse capítulo faço uma breve recuperação do histórico do movimento por diversidade e direitos trans* no Brasil e o situo no debate atual quanto à questão dos direitos das pessoas transexuais e travestis, os conceitos de gênero e o de cidadania. Abordo também um conjunto de legislações, tratados e acordos internacionais e nacionais que tratam sobre os direitos humanos das pessoas LGBTQIA e são as bases do Estado para a promoção de políticas de fim da desigualdade na diversidade de sexo e gênero.

No quarto capítulo, realizo a introdução aos conceitos de Política Pública. Nele apresento elementos para justificar o porquê dela ser utilizada como ferramenta para atender as demandas da população transgênero, dando destaque para travestis e transexuais, no contexto do Estado de Direito e do Direito Internacional e uma possível ferramenta de análise, O Ciclo de Políticas Públicas de Ball. (Mainardes, 2006) $\mathrm{Na}$ quinta sessão temos a descrição e apresentação do programa TransCidadania, tomando-o como uma tentativa do município de São Paulo de responder às demandas de políticas públicas dirigidas a pessoas trans*. Descrevo e busco analisar seu processo de elaboração, criação, cotidiano e o primeiro balanço oficial do programa e apresento o resultado do processo de observação. 
No sexto capítulo, há análise dialógica e a transcrição de trechos de entrevistas com gestores e as participantes, analisando as metas do programa a partir do conjunto dos resultados da pesquisa, e outros indicadores ressaltados pelas pessoas participantes que e influenciaram suas vivências ao longo do programa.

Por fim, nas considerações finais retomo os objetivos do trabalho, e apresento minhas sugestões. 


\title{
2 UMA BREVE DISCUSSÃO SOBRE GÊNERO, SEXO E SEXUALIDADES
}

\begin{abstract}
Tenho as opiniões desmentidas, as crenças mais diversas É que nunca penso nem falo nem ajo... Pensa, fala, age por mim sempre um sonho qualquer meu em que me encarno no momento.

Vem a fala e falo-eu-outro. De meu, só sinto uma incapacidade enorme, um vácuo imenso, uma incompetência ante tudo o que é a vida. Não sei os gestos a acto nenhum real. Nunca aprendi a existir.
\end{abstract}

(Fernando Pessoa)

\subsection{Norma e contranorma: "o quê" e "por quê" do gênero}

A compreensão de gênero que utilizo nesse trabalho vai na contra-mão da lógica binária heteronormativa construída e regente na sociedade atual, que compreende as identidades de gênero como uma correlação coerente e contínua entre sexo biológico e o gênero construído culturalmente, e ainda, o desejo e prática sexual, onde, a partir disso se exclui ou trata como desvio quaisquer das outras identidades.

Por isso, neste capítulo faço uma breve discussão sobre a concepção de gênero, travestilidade e transexualidade que dialoga diretamente com este trabalho, utilizando discussões importantes sobre estudos de gênero tais como (Pedro, 2005; Nicholson, 2000; Scott, 1994; Butler, 2003; Jesus, 2012), porém com o olhar mais focado nos debates sobre transexualidade e travestilidade, cujos trabalhos etnográficos (Pelúcio, 2009; Bento, 2005; Benedetti, 2005; Kulick, 19988; Duque, 2011) contribuíram para uma visão mais ampla sobre as particularidades desse grupo, vivências, experiências e pautas históricas de reivindicação.

Para a teoria contemporânea, gênero é uma relação dialógica de autoconhecimento e reconhecimento de implicações sociais, culturais, psicológicas e biológicas.

Assim, de acordo com Jesus (2012, p.12) gênero teria a ver não com formas fixas do ser, mas com "formas de se identificar e ser identificado(a)". A teórica Linda Nicholson acredita que gênero esteja associado a "estereótipos culturais de personalidade e comportamento", e, "as formas culturalmente variadas de se entender como corpo". 
Defendo que a população humana difere, dentro de si mesma, não só em termos das expectativas sociais sobre pensamos, sentimos e agimos; há também diferenças nos modos como entendemos o corpo. (Nicholson, 2000, p.6)

Esse entendimento pressupõe uma concepção de gênero em oposição ao determinismo biológico e de significado dado das relações de poder, mas também rompe a associação obrigatória sobre corpo, sexo, gênero e prática sexual, o entendendo como construção social sobre o corpo, e principalmente, possibilitaria a reflexão das existências de outros corpos, afastando ainda mais do discurso de gênero do essencialismo biológico (Pedro, 2005, p.90). A noção vigente hoje nos estudos de gênero e sexualidade, contudo, nem sempre se construiu desta forma.

\subsection{A evolução do conceito de gênero}

O conceito de gênero sofreu modificações em seu significado em diversos momentos da história, para expressar os avanços de pensamento sobre os estudos que se desenvolviam. Porém, o conceito sempre esteve atrelado ao questionamento a respeito de se gênero seria a um tempo biológico ou social. Neste percurso se avaliou o conceito de gênero a partir da biologia, da sociedade, da função da mulher na sociedade, das relações dos gêneros já instituídos e atualmente, entre todas estas e as outras possibilidades de gênero e até o além do gênero, ou seja, sua superação. Este movimento se deu, principalmente, em virtude do movimento feminista e de mulheres, que ousou no decorrer da história, especialmente nas décadas de 1970 e 1980, questionar e entender a divisão sexual, e as opressões por gênero que sentiam (Guedes, 1995, p.7; Pedro, 2005, p. 78).

\subsection{Rubin: a opressão da mulher na divisão do gênero na sociedade}

Trataremos a seguir da genealogia do conceito de gênero. 


\title{
2.3.1. Rubin e o tráfico de mulheres
}

Para começar uma genealogia do conceito de gênero, partiremos de um texto de Gayle Rubin, importante antropóloga estadunidense, em seu ensaio intitulado "EI tráfico de mujeres: Notas sobre la economía política del sexo, Nueva antropología", de 1975, que desenvolveu o conceito de "sistema genêro/sexo", onde a autora defende ser o sexo um dado biológico e imutável, e o gênero um conjunto de características socialmente atribuídas a grupos definidos e separados pelo sexo: "El género es una división de los sexos socialmente impuesta. Es un producto de las relaciones sociales de sexualidad" (Rubin, 1986, p. 12). "el conjunto de disposiciones por el que una sociedad transforma la sexualidad biológica en productos de la actividad humana, y en el cual se satisfacen esas necesidades humanas transformadas (Rubin, 1986, p. 97)".

\begin{abstract}
A falta deum termo mais elegante, nomeio este aspecto da vida social de "sistema de sexo/gênero". Adoto como definição preliminar de um 'sistema de sexo/gênero": um conjunto de arranjos através dos quais uma sociedade transforma a sexualidade biológica em produtos da atividade humana, e na qual estas necessidades sexuais transformadas são satisfeitas. (Rubin 1986, p. 97)
\end{abstract}

Para a pesquisadora, gênero não é apenas uma identificação com um sexo, mas um sistema de imposições de comportamentos que obriga e orienta a respeito do desejo sexual, divisão de trabalho, casamento, parentesco e dessa forma oprime mulheres. Este sistema, que a autora vai chamar de sistemas sexo/gênero. Sistemas de sexo/gênero seriam sistemas impostos baseados no sexo genital que criariam condições para a opressão das mulheres, e que tratariam como desviante todo aquele que não se comporta como os padrões normativos sexuais.

Poder-se-ia então parafrasear: o que é uma mulher domesticada? Uma fêmea da espécie. Uma explicação é tão boa quanta a outra: uma mulher é uma mulher. Ela só se toma uma doméstica, uma esposa, uma mercadoria, uma coelhinha, uma prostituta ou ditafone humano em certas relações. Retirada dessas relações, ela não é mais companheira do homem do que o ouro, em si mesmo, é dinheiro... (Rubin 1986 p. 97) 
Estes padrões, como geralmente voltados para a reprodução, para a produção de recursos 24 , eram sempre cisheteronormativos e controlados por homens. Ou seja, a imposição de gênero condicionaria uma estrutura social, que apoia, reproduz e reforça a si mesma, de modo que essa estrutura pareça ser natural pelo reforço interno (Rubin, 1986).

Ao contrario de Beauvoir, Rubin cria que mulheres não eram oprimidas por seu sexo, mas, ao contrário, esta era naturalizada pela imposição do gênero e suas relações de trabalho e parentesco, de forma que mulheres e homens cressem que esse era o destino natural das coisas. E, ainda que Gayle Rubin já entendesse o gênero como algo distinto e não naturalmente dado pelo sexo, sua visão naquele momento ainda fazia uma relação entre sexo e gênero, apontando que a determinação sócio cultural do gênero era dada pela compreensão sócio cultural do que se entendia como sexo. Alguns anos mais tarde, ela vai compreender que as políticas sexuais do gênero não atingem a formação das identidades conhecidas e reforçadas no sistema, como criminalizam e banem todas as outras formas para sua perpetuação, gerando toda uma nova cadeia de opressão baseada na não conformidade.

Etc. O que são então essas relações através das quais uma fêmea torna-se uma mulher oprimida[...] A domesticação das mulheres, sob outras denominações, está largamente discutida [...]. Lendo-se esses trabalhos, começa-se a adquirir o sentido de um aparato social sistemático que toma as fêmeas como matéria-prima e modela as mulheres domesticadas como produtos. [...] Ainda assim, eles fornecem instrumentos conceituais com os quais é possível construir descrições da parte da vida social que o locus da opressão das mulheres, das minorias sexuais e de determinados aspectos da personalidade humana nos indivíduos. (Rubin 1986 p. 97)

2.3.2 Pensando o sexo: Rubin e as políticas de controle da sexualidade e do gênero

24 Rubin acredita que mulheres são compradas, trocadas, dadas e vendidas como recursos reprodutivos, em troca de paz, recursos produtivos como bens em espécie, e como símbolos de aliança reprodutiva nas condições impostas por sistemas sexo/gênero baseados na hierarquia de superioridade dos homens sobre as mulheres. 
É em Thinking Sex: Notes for a Radical Theory of the Politics of Sexuality de 1989 que temos um trabalho mais elaborado e focado em relações sociais contemporâneas sobre sexo e gênero atuando juntos nas identidades e opressões (de Jesús, 2013, p.46.). Nesse artigo a pesquisadora se coloca de maneira a discutir e reconhecer a diversidade sexual como parte do sistema, e que o controle desta também estaria relacionado à manutenção de seus modos de produção e reprodução. Ela agora reflete o gênero relacionando-o com as relações de poder, e não mais como algo que opera a partir da leitura do sexo, tido como natural, mas das noções de conformidade e inconformidade com as leituras sociais do sexo e sempre com base nas práticas sexuais normatizadas.

Essa noção de poder que Gayle Rubin aponta, se percebe ser influenciada pela visão construcionista dos trabalhos de Michael Foucault acerca do Poder.

não tomar o poder como um fenômeno de dominação maciço e homogêneo de um indivíduo sobre os outros, de um grupo sobre os outros, de uma classe sobre as outras, mas ter bem presente que o poder - desde que não seja considerado de muito longe - não é algo que se possa dividir entre aqueles que o possuem e o detêm exclusivamente e aqueles que não o possuem e lhe são submetidos. O poder deve ser analisado como algo que circula, ou melhor, como algo que só funciona em cadeia. Nunca está localizado aqui e ali, nunca está em mãos de alguns, nunca é apropriado como uma riqueza ou um bem. O poder funciona e se exerce em rede. Nas suas malhas, os indivíduos não só circulam, mas estão sempre em posição de exercer este poder, e de sofrer sua ação; nunca são alvos inertes ou consentidos do poder, são sempre centros de transmissão. Em outros termos, o poder não se aplica aos indivíduos, passa por eles (Foucault, 1989 , p. 183). 
com base nessa linha de raciocínio, introduz as proposições: [...] que o poder não é algo que se adquire, arrebate ou compartilhe, algo que se guarde ou deixe escapar; o poder se exerce a partir de inúmeros pontos e em meio a relações desiguais e móveis; que as relações de poder não se encontram em posição de exterioridade com respeito a outros tipos de relações [...] mas lhe são imanentes [...]; que o poder vem de baixo; isto é, não há, no princípio das relações de poder, e como matriz geral, uma oposição binária e global entre os dominadores e os dominados, dualidade que repercute de alto a baixo e sobre grupos cada vez mais restritos até as profundezas do corpo social [...]; que as relações de poder são, ao mesmo tempo, intencionais e não subjetivas. Se, de fato, são inteligíveis, não é porque sejam efeito, em termos de causalidade, mas porque atravessadas de fora a fora por um cálculo: não há poder que se exerça sem uma série de miras e objetivos. Mas isso não quer dizer que resulte da escolha ou da decisão de um sujeito, individualmente [...]; que lá onde há poder há resistência e, no entanto (ou melhor, por isso mesmo) esta nunca se encontra em posição de exterioridade em relação ao poder (Foucault, 1988, p. 104-105).

Para Foucault o poder não é algo fixo, nem proprietário. Ele é fruto de relações estratégicas e instáveis, sendo de caráter dinâmico. Ele não se resume a proibições e obrigações, pois, o poder também pode ser produtivo dadas suas relações. É nessa visão de poder que se ampara o discurso de Gayle Rubin acerca do entendimento do gênero como também produtor e reprodutor de relações de poder, ou seja, embora exista uma classe controlando o poder através de diversos dispositivos25, o poder não é fixo dessa classe.

Para Rubin, a forma de organizar o sistema sexo gênero em apenas uma sexualidade singular permitida, e validada pelo Estado, religiões e instituições faz dele uma forma de poder coercitivo:

A noção de uma sexualidade ideal singular caracteriza a maioria dos sistemas de pensamento sobre o sexo. Para a religião o ideal é o casamento procriativo. Para a psicologia é a heterossexualidade madura. Apesar de se variarem os conteúdos, o formato de um padrão sexual singular é continuamente reconstituído dentro de outros enquadramentos retóricos, incluindo o feminismo e o socialismo. É tão objetivável quanto insistir que todos deveriam ser lésbicas, nãomonogâmicos, ou bizarros, como acreditar que todos deveriam ser heterossexuais, casados ou baunilha - apesar da última série de opiniões ser respaldada por poderes consideravelmente mais coercitivos que os primeiros. (Rubin, 1993, p. 28)

\footnotetext{
${ }^{25}$ Utilizo aqui a noção de dispositivo criada por Michael Foucault em História da sexualidade - Volume I, de 1985 -, onde o mesmo compreende que existe uma rede estabelecendo conexões de discursos entre saberes diferentes entre eles legislações, argumentos científicos, filosóficos, morais, religiosos entre outros. Com a função de responder e orientar a uma questão histórica que é a sexualidade. Outras autoras vão utilizar também os conceitos de tecnologias de gênero, como Teresa de Lauretis,
} 
Poder este que quando em Estados conservadores ou em contato com novas formas de diversidade sexual, fazem com que as leis e o Estado passem a procurar intervir nas práticas sociais e de gênero, contribuindo para a criação dos tabus e do proibido em termo de sexo, gênero, legalidade e direitos. Algumas práticas sexuais levaram às leis de costumes que deflagraram a perseguição a LGBTQIA em Stonewall. Conflito agressivo que se deu entre polícia e comunidade LGBTQIA e que foi iniciado pela travesti Marsha P. Johnson e leis anti-sodomia de forma geral:

O poder coercitivo da lei garante a transmissão dos valores sexuais conservadores com esses tipos de controle sobre a parentalidade e a prática docente. $O$ único comportamento sexual adulto que é legal em todos os estados é a colocação do pênis na vagina no matrimônio. Estatutos de consentimento adulto aperfeiçoam essa situação em menos que metade dos estados. A maioria dos estados prevê penalidades criminais severas para a sodomia consensual, adultério, sedução e incesto adulto. Leis de sodomia variam muito. Em alguns Estados elas se aplicam tanto a parceiros homossexuais como heterossexuais e independem do status marital.

(...) Leis como essas criminalizam o comportamento sexual que é livremente escolhido e avidamente procurado. A ideologia incorporada nelas reflete as hierarquias de valor discutidas acima. Isso é, alguns atos sexuais são considerados como intrinsecamente pervertidos que ninguém deveria ser permitido de praticá-los sob nenhuma circunstância. $O$ fato de indivíduos consentirem ou até mesmo preferirem eles são tomados como evidência adicional da depravação. Este sistema de legislação sexual é similar ao racismo legalizado. A proibição estatal do contato sexual entre pessoas do mesmo sexo, penetração anal e sexo oral faz com que os homossexuais sejam um grupo criminoso negados do privilégio da cidadania total. (Rubin, 1993, 28-29)

\subsection{Scott: gênero como categoria analítica relacional}

Joan Scott também analisa gênero como uma relação de poder e uma categoria analítica que envolve estudos sobre as questões das mulheres, mas também dos homens, levando em consideração outros elementos também como classe e raça. Para a autora gênero é fruto das relações sociais na disputa de poder advindas, que a partir da observação das diferenças entre os sexos (biológico), tenta dar sentido às relações de poder, por onde esse poder é articulado (Scott, 1990, p.14).

De acordo com Scott (1994) seus estudos sobre gênero possuem: 
[...] duas partes e diversas subpartes. Elas são ligadas entre si, mas deveriam ser distinguidas na análise. O núcleo essencial da definição repousa sobre a relação fundamental entre duas proposições: o gênero é um elemento constitutivo de relações sociais fundadas sobre as diferenças percebidas entre os sexos e o gênero é um primeiro modo de dar significado às relações de poder. (Scott 1994, p.21)

Cabe ressaltar que Scott (1994) não defendia gênero como uma forma de categorizar ou refletir diferenças físicas e naturais entre homens e mulheres, ao contrário disto. Como historiadora, acreditava que era necessário ir além e "apontar e modificar as desigualdades entre homens e mulheres", analisando como os gêneros "nascem de uma disputa política e são os meios pelos quais as relações de poder - de dominação e de subordinação - são construídas" e por fim, demostrando com isso como "as hierarquias de gênero são construídas, legitimadas, contestadas e mantidas" (Scott, 1994, p.11-14).

\subsection{Nicholson contra o fundamentalismo de gênero.}

Porém, se por um lado o pensamento de Scott nos impulsiona a análise de gênero como categoria política, Nicholson (2000), apontaria que os estudos continuavam estabelecendo relação entre sexo e gênero, ainda que distinta, que a autora chamou de "fundacionalismo biológico", pois para ela as feministas ainda entendiam o sexo como base na construção do gênero na sociedade.

Tal concepção do relacionamento entre a biologia e a socialização torna possível o que pode ser descrito como uma espécie de noção 'porta casacos' da identidade: o corpo é visto como um tipo de cabide de pé no qual são jogados diferentes artefatos culturais especificamente os relativos à personalidade e comportamento. Tal modelo permitiria às feministas teorizar sobre o relacionamento entre biologia e personalidade aproveitando certas vantagens do determinismo biológico, ao mesmo tempo em que dispensando certas desvantagens. [...] Rótulo essa noção de relacionamento entre corpo, personalidade e comportamento de fundacionalismo biológico (Nicholson, 2000: 12). 
Nicholson (2000) contribui significativamente para pensarmos no corpo biológico como algo complexo que está dentro de uma cultura, uma história. Ela nos possibilita a pensar, por exemplo, nas pessoas travestis e mulheres e homens transexuais, sujeitos com quem dialogamos neste trabalho, uma vez que a autora nos permite enxergar pessoas travestis e transexuais como indivíduos, diferentes de qualquer outra pessoa, assim como todos são todas as pessoas diferentes entre si.

Assim como Nicholson (2000) pensou o sentido da "mulher" nas suas múltiplas subjetividades, podemos utilizar a autora para extravasar seu pensamento para outras áreas do conhecimento sobre gêneros não hegemônicos, a exemplo das pessoas travestis e transexuais:

"Quero sugerir que pensemos no sentido de "mulher" do mesmo jeito que Wittgenstein sugeriu pensarmos o sentido de "jogo", como uma palavra cujo sentido não é encontrado através da elucidação de uma característica específica, mas através da elaboração de uma complexa rede de características" (Nicholson, 2000, p.35).

[...] Assim, essa postura não refuta a ideia de que o corpo bissexuado teve seu importante papel na estruturação da distinção masculino/feminino, e, portanto no sentido de mulher, ao longo de uma parte da história humana. Entretanto ela exige que sejamos claros sobre qual foi exatamente essa parte, e até mesmo dentro dela, sobre os contextos nos quais essa distinção não se aplica. Mais do que isso, por assumir que o sentido de mulher se alterou ao longo do tempo, essa postura assume também que aquelas/es que atualmente defendem formas não tradicionais de compreendê-lo, como os transexuais por exemplo, não podem ser deixados de lado sob a simples alegação de que suas interpretações contradizem os padrões usuais (Nicholson, 2000, p.36).

Com base nos estudos de Laqueur (apud Nicholson, 1994), a autora problematiza o binarismo dos corpos, que refletem discursos sociais produzidos através de interesses e que possuem uma historicidade, e por consequência tende a normatizar gêneros, comportamentos e sexualidades de acordo com preceitos e entendimentos colonialistas sobre o tema. $\mathrm{E}$ a respeito diz: 
E como aqueles que têm poder para fazê-las nas sociedades de origem europeia contemporâneas geralmente são brancos, heterossexuais e profissionais de classe média, tais caracterizações tendem a refletir a predisposição desses grupos (Nicholson, 2000, p.28).

Assim como Linda Nicholson (2000) acreditava que a palavra gênero e mulher não eram categorias fixas, e que ambas transbordavam nos sentidos dados até então, principalmente ao que tangia ao binarismo dos corpos.

\subsection{Butler e o gênero como performance}

A filósofa pós-estruturalista 26 Judith Butler via como um ato autoritário em si categorizar o termo gênero e mulheres, e quaisquer forma de limitar essas compreensões. Tais pesquisadoras afastam o conceito gênero e sexualidade ainda mais do determinismo biológico, entretanto, Judith Butler vai além ao considerar o sexo como um produto "discursivo/cultural" e questiona a relação de gênero como construção cultural e sexo como natural (Butler, 2003, p.25).A obra de Butler (2003) é considerada como precursora e expoente da Teoria Queer, que, segundo Bento (2006):

O termo queer surge como uma interpelação que discute a questão da força e da oposição, da estabilidade e da variabilidade no seio da performatividade. Esse termo tem operado como uma prática linguística cujo propósito tem sido o da degradação do sujeito a que se refere, ou melhor, a constituição desse sujeito mediante esse apelativo degradante. Queer adquire todo seu poder precariamente através da evocação reiterada que o relaciona com acusações, patologias e insultos (Butler, 2002, p. 61 apud Bento, 2006, p. 80-81, grifo no original).

A teoria queer ganhou espaço principalmente dentro dos movimentos trans* por possibilitar o questionamento sobre sexo, sexualidade e gênero que rompesse com a norma padrão heterossexual 27 e com o binário. $E$ foi então possível uma compreensão maior sobre o porquê gênero é uma categoria histórica e dinâmica, podendo ser contestada e reconstruída a cada novo momento histórico. Nesse sentido, a Butler desenvolveu a teoria da performatividade:

\footnotetext{
${ }^{26}$ De acordo com Bueno (2015, p.1) o pós-estruturalismo francês constitui-se em movimentos reflexivos da maior importância na área da filosofia da educação, inspirando inúmeras produções acadêmicas nas últimas décadas. Sendo contemporâneos às décadas de 1950 e 1960, ambos os movimentos apresentam em comum o fato de oporem resistência filosófica a diversos tipos de totalitarismo.

${ }^{27}$ Heterossexual, ou apenas hetero, pessoa que se atrai romântica e sexualmente pelo gênero oposto.
} 
"O gênero é performativo porque é resultante de um regime que regula as diferenças de gênero. Neste regime os gêneros se dividem e se hierarquizam de forma coercitiva" (Butler, 2002, apud Bento 2006, p. 64).

A teoria da performatividade tem gerado bastante discussão dentro de movimentos que se denominam por subversivos. Para Butler existe um processo de reiteração performativo que cria como produto a heterossexualidade como norma padrão, mas também cria outros corpos que ela vai chamar de corpos "abjetos", que é o anormal, sujeito degradado, a referência contrária para que o padrão possa se colocar como normal e bom (Butler, 2005). E essa norma, não apenas se estabelece no imaginário cultural como traz diversas consequências para todos aqueles que ousam a romper com ela.

Entretanto, esses ditos corpos "abjetos" também são sujeitos, falam, possuem necessidades e histórias. Histórias essas que rompem o aspecto individual e se mostram experiências coletivas. E é porque esses outros corpos falam e possuem histórias, que políticas públicas estão sendo cada vez mais reivindicadas para atender essas vozes que lutam por suas demandas históricas do movimento trans*, como é o caso do programa TransCidadania e outros ações que foram/estão sendo realizadas.

\subsection{Diversidade feita carne: conceitos a respeito de travestilidade e transexualidade.}

As experiências da travestilidade 28 e da transexualidade 29 são temáticas de pesquisas desde a década de 1950, aparecendo com mais frequência nos estudos das ciências sociais e da antropologia, tendo ganhado mais visibilidade e centralidade nas pesquisas brasileiras a partir dos anos 2000 (Concilio et. al, 2014).

\footnotetext{
${ }^{28}$ De acordo com Peres (2005, p.26) o conceito de travestilidade contempla a multiplicidade de possibilidades entre as mais variáveis experiências e modos de vida de travestis, a fim de não engessar as possibilidades de vivências, e sim considerando as diversas possibilidades de existência.

${ }^{29}$ Segundo Bento (2008) no livro O que é transexualidade podemos inferir que transexualidade diz respeito a pessoas que buscam legitimidade social ao que se refere às práticas e identidade de gênero, estando esta dissociada da sexualidade.
} 
As travestis e transexuais foram incorporadas ao movimento LGBTQIA Brasileiro nos anos de 1970 e 1990 respectivamente, trazendo consigo demandas específicas destas populações, tendo como ponto de partida as questões relacionadas ao trabalho sexual, à AIDS e seu estigma, e, consequentemente, ao aumento da violência direcionada a elas que, segundo Facchini (2011, p.16), são a ponta mais visível e exposta da comunidade LGBTQIA.

De acordo com Carvalho e Carrara (2013, p. 322) no início da década de 1960 o conceito "travestis" não era tido como uma categoria identitária e sim como uma expressão como: "ter uma travesti", ou um personagem drag, e "estar em travesti", ou seja, estar vestido em um personagem.

"As "bichas" muitas vezes realizavam festas e concursos nos quais se vestiam com indumentárias femininas e assim apareciam "em travesti", prática que era proscrita para os "bofes". Um bom exemplo desses eventos eram os famosos bailes de travestis realizados durante o carnaval no Rio de Janeiro" (Costa, 2010 e Green, 2000 apud Carvalho e Carrara, 2013, p. 322)

O movimento gay da década de 1960 procurava distinguir a pessoa gay que se atrai por alguém do mesmo sexo (sendo sexo aqui, entendido como o biológico/genitália), da pessoa que performatiza uma pessoa do sexo oposto. Para tais pessoas, o movimento gay se referenciava como "bichas", "afeminadas", "pintosa", "fechativa" e mais a frente, chamava-as de "travestis" (Como uma forma de referenciar uma bicha exageradamente pintosa), permitindo que com isso, gradativamente, a travesti começasse a ganhar contornos como uma categoria identitária. Recebendo uma nova visibilidade social, a partir dos anos 1970, que veio cheio de estigmas ligados a prostituições, furtos e drogas. (Carvalho e Carrara, 2013, p.324).

De acordo com Leite (2008, p. 192), a travestilidade no meio médico é assimilada a desvio e perversões sexuais, enquanto que a transexualidade é associada à doença, que poderia ser "corrigida" através da cirurgia transgenitalizadora. Visões que contribuem negativamente na vida da população trans* .

Ainda, de acordo com o mesmo autor, a travesti é conhecida no Brasil como uma pessoa que foi identificada como homem ao nascer e socializada como tal através das performances que se entende atualmente como masculina. Porém, passou a viver performatizando como o que é caracterizado na sociedade como o ser mulher/feminino, realizando mudanças corporais (hormônio-terapia, implante de silicone), até mesmo a cirurgia transgenitalizadora. 
Em relação à cirurgia transgenitalizadora Pelúcio (2009, p. 288) sinaliza ainda, que diversas travestis não possuam o interesse de se submeter ao processo cirúrgico, em muitos casos por conviverem com suas genitálias sem conflitos. Ainda existe entre as mesmas, a intensa busca pelo corpo "perfeito", o que não é plenamente alcançado apenas pela utilização de vestimentas ditas femininas, em busca do tornar-se travesti. Para Jesus (2012, p.14) as travestis são pessoas que "vivenciam papéis de gênero feminino, mas não se reconhecem como homens ou como mulheres, mas como membros de um terceiro gênero ou de um não-gênero". Esse conceito feito pela autora apesar de entender a pessoa travesti como algo distinto das identidades definidas na sociedade, ele ainda trata a demonstração do ser subjetivo da travesti como uma representação de "papéis de gênero feminino", ou seja, reconhecendo um binarismo quanto às formas de ser de um sujeito.

Para Beatriz P. Bagagli (2015) 30:

Não é possível fazer um conceito de travesti, não é possível fazer uma entrada no dicionário e circunscrever os sentidos sobre travesti como uma nosologia. Por isso não é possível fazer um laudo com diagnóstico de travestilidade. A travestilidade resiste ao laudo, não é passível de ser escrita. Travesti é o próprio devir do gênero; liberando a travesti do pensamento liberamos o gênero da patologia, do sistema fálico e cissexista. Pane no cistema (Baglagi, 2015).

A discussão que Beatriz Bagagli menciona em seu texto quanto a travestilidade, nos leva a reflexão sobre a necessidade de refletir sobre o outro, dissociando da necessidade que se tem de conceituar e definir os sujeitos, libertando a identidade de gênero dos limites sociais das políticas públicas que nos condiciona a pensar em forma de caixas (estáveis e delimitadas) para se desenhar uma política para grupos específicos, por exemplo.

As travestilidades "podem ser vistas como processos(...) de construção de um certo feminino, muitas vezes glamorizado, ligado historicamente à noite e às artes cênicas" (Pelúcio, 2007 p. 2 ), que foi historicamente organizado dada as grandes aglomerações urbanas, que comungam entre si valores morais, éticos e estéticos sobre questões ligadas a gênero e sexualidade (Pelúcio, 2009, p. 253 - 291).

\footnotetext{
${ }^{30}$ Beatriz P. Bagagli é colunista do site transfeminismo, graduada em Letras - Língua Portuguesa pela Universidade Estadual de Campinas (2015). Tem experiência na área de Lingüística, com ênfase em Teoria e Análise Lingüística, atuando principalmente nos seguintes temas: teoria queer, gênero e transfeminismo. $O$ texto citado encontrasse no site Transfeminismo https://transfeminismo.com/a-travestilidade-como-resistenciaa-logica-diagnostica/
} 
Já a transexualidade, começou a ser oficialmente estudada na década de 1950, quando foram publicados os primeiros artigos que, além de defender, registraram a especificidade do "fenômeno transexual", contribuindo mais a frente para o debate sobre a transexualidade como possibilidade de uma categoria identitária "transexual" que é diferente da "travestis", isso no final dos anos 1990 e inicio dos anos 2000, quanto o T da sigla LGBTQIA também passou a se referenciar para pessoa transexual (Carvalho e Carrara, 2013, p. 331).

A pessoa transsexual, homem ou mulher, de acordo com Bento (2008, p. 12), são pessoas que "reivindicam o pertencimento a um gênero distinto daquele que the foi imposto", ou seja, diferente daquele gênero que lhes foi designado ao nascer baseado na genitália, na lógica do determinismo biológico, onde sexo e gênero estão intrinsecamente ligados e um determina o outro. E a "transexualidade é um desdobramento inevitável de uma ordem de gênero que estabelece a inteligibilidade dos gêneros no corpo" (Bento, 2008, p. 19)

A pessoa transexual não segue a rigor essa lógica, elas "lidam de formas diferentes, e em diferentes graus, com o gênero ao qual se identificam... Cada pessoa transexual age de acordo com o que reconhece como próprio de seu gênero" (Jesus, 2012, p.14). Essa afirmação sobre o poder de decisão das pessoas trans* sobre seu corpo e comportamento é de extrema importância para o debate sobre o que caracteriza a transsexualidade. Pois, se no passado recente as pessoas transexuais só eram assim determinadas após a cirurgia de redesignação de genitália, muito embora a reivindicação sobre cirurgia ainda exista, a autora nos induz a romper com a lógica de que uma pessoa transexual nasce em um "corpo errado". Esta compreensão para dar? liberdade de escolha do indivíduo sobre seu corpo, preservando a pluralidade onde "as pessoas transexuais são diferentes umas das outras, assim como todas as demais pessoas não transexuais." (Sampaio \& Coelho, 2013, p. 2). 


\title{
3 CONSTRUINDO UM CAMINHO PARA AS POLÍTICAS PÚBLICAS
}

\author{
"As Bi, as Gay, as Trava e Sapatão. Tão tudo organizadas \\ pra fazer revolução". (Palavra de ordem em marchas lgbtqia).
}

\subsection{Um breve histórico do movimento de travestis e transexuais no Brasil.}

Diversos movimentos sociais, em especial os movimentos de travestis e transexuais, e reconhecimento de suas identidades, vêm conseguindo provocar debates importantes sobre reivindicações históricas da população trans*. As demandas a respeito da saúde, combate à epidemia da AIDS, violência, e direito de herança, entre outras demandas ligadas à cidadania plena, como por exemplo educação, empregabilidade, e reconhecimentos de suas identidades.

E essa efervescência, que tem chamado atenção de diversos pesquisadores e gestores vêm conseguindo provocar debates importantes sobre reivindicações históricas da população trans*. As demandas a respeito de saúde, combate à epidemia da AIDS, violência, e direito de herança, entre outras ligadas à cidadania plena, como por exemplo educação, empregabilidade da sociedade civil, não é recente, embora atualmente tenha ganhado certo fôlego dados os avanços em pesquisa e discussão sobre sexualidades e gênero, bem como devido à consolidação do movimento trans* no Brasil nos recentes anos 1990.

Surgido em meados da década de 1970, e influenciado por Stonewall, o movimento trans* do Brasil representava uma nova identidade dentro do movimento gay brasileiro. Nesse primeiro momento, atua resistindo contra a repressão de costumes na Ditadura Militar. Em meados de 1980 se concentra juntamente com o movimento homossexual no combate e prevenção da epidemia nascente de AIDS. Carvalho e Carrara (2013, p. 323), destacam como o movimento gay enxergavam as travestis e transexuais que se aproximavam ao movimento, que, segundo esses, as pessoas trans* eram vistas como forma degradante da homossexualidade, irresponsáveis, fugindo do modelo homossexual discreto. 
O movimento homossexual entrou em cena no final de 1960 e início da década de 1970, na luta contra a ditadura militar, e, mais tarde, em diálogo com os movimentos sociais nascidos durante o processo de transição para a democracia, na década de 1980 (...) Foi também nessa década que o movimento enfrentou a epidemia da AIDS e concentrou-se na busca de respostas coletivas ao seu combate, promovendo mudanças nas políticas públicas de saúde. (Vianna, 2015, p.797).

Essa forma de olhar e tratar as pessoas trans*, através de estigma e exclusão pelo movimento gay, contribuíram para o surgimento de uma categoria nova de identidade, que, se por um lado ganhava visibilidade e caminhava para que suas demandas fossem concebidas como pautas de políticas únicas no movimento LGBTQIA, ainda sofria com a secundarizarão de suas pautas dentro do próprio movimento (Carvalho, 2011).

O apagamento das identidades não masculinas cisnormativas e hegemônicas, embora remonte o início do processo de surgimento das identidades trans* e da conformação do movimento LGBTQI no Brasil, é apontado por outros autores ainda hoje:

\begin{abstract}
A emergência do debate da transexualidade - e a luta por sua despatologização - denuncia o quanto o movimento é e sempre foi GGGG, e a falta de cuidado com que as demandas trans vem sendo tratadas faz pensar que o $\mathrm{T}$ em nossa sigla é apenas decorativo. $\mathrm{O}$ apagamento das questões lésbicas é - que ironia - visível em sua ausência. Quando se pensa em saúde LGBT, o foco ainda são os homens gays e o HIV, mas pouco se fala sobre a saúde da mulher lésbica ou sobre o tipo de violência especificamente direcionada a essas pessoas. A bissexualidade é negada, é motivo de chacota. $E$ as identidades não binárias, a assexualidade e discussão queer ainda são vistas como muito complicadas para o povo, como domínio da academia (Longo $\left.{ }^{31}, 2015\right)$.
\end{abstract}

A violência contra pessoas travestis e transexuais, como vimos, também remonta a décadas passadas. Durante o período de coerção de costumes da ditadura militar no Brasil, ataques às pessoas LGBTQIA em geral, mas especialmente contra as travestis que se prostituíam, foram realizados de maneira sistemática, para exterminar essa população, tudo discutido e fundamentado por decisões políticas de higienização da época (Carvalho, 2011; Figari, 2007; Green, 2000; Moreira \& Moreira, 1988).

31 Fabricio Longo é ativista e militante LGBT, colunista da revista forúm. https://www.revistaforum.com.br/osentendidos/2015/05/27/movimento-discurso-lgbt-4/. 
$\mathrm{Na}$ tentativa de promover a denúncia das políticas de extermínio LGBTQI e combater as violências e prisões cometidas contra pessoas trans* e homossexuais, mas também com o intuito de reunir politicamente essas populações, surge na cidade do Rio de Janeiro no início dos anos de 1990 a Associação das Travestis e Liberados (ASTRAL), que resultou em 1993 no I Encontro Nacional de Travestis e Liberados. A ASTRAL ainda exerceu uma importante função na luta contra a epidemia do HIVIAIDS, e na formação de travestis e transexuais em suas construções no campo jurídico e político (Carvalho \& Carrara, 2013, p. 326).

Há um significativo crescimento do movimento com a criação, em 1995, da Associação Brasileira de Gays, Lésbicas e Transgêneros (ABGLT), o que mobilizou a presença de novos atores e a propagação de ações no âmbito legislativo e na luta por ampliação dos direitos (Vianna, 2015, p.798)

Além da ASTRAL outros grupos começaram a ser formados tanto nas esferas municipais, quanto regionais e nacionais. Foi o caso da Rede Nacional de Travestis e Liberados (RENTRAL), que veio depois a ser chamada Rede Nacional de Travestis (RENATA) conectados às demandas trans* ${ }^{*}$ ao combate e prevenção da HIVIAIDS, tais como o Programa Nacional de DST/AIDS.

Encontros para organização e articulação trans* passaram-se a ser anuais, e mais tarde vieram a se chamar de Encontros Nacionais de Travestis e Transexuais na Luta contra a AIDS (ENTLAIDS), atualmente sendo chamados apenas de Encontros Nacionais de Travestis e Transexuais.

A partir do estabelecimento desses encontros, vários outros espaços de debate foram formados, e com eles outras organizações surgiram. Como por exemplo, a maior rede formada por travestis e transexuais da América Latina: a Articulação Nacional de Travestis, Transexuais e Transgêneros (ANTRA) fundada nos anos 2000, e que permanece ativa até os dias de hoje. (Carvalho \& Carrara, 2013, p. 328). 
Para a Vianna (2015) uma nova relação entre os movimentos sociais LGBTQIA e o Governo passou a ser consolidada a partir de 2003, o que resultou em vitórias institucionais como a criação da Secretaria de Educação Continuada, Alfabetização e Diversidade (SECAD) em 2004, do programa Brasil Sem Homofobia: Programa de Combate à Violência e à Discriminação Contra LGBTs e de Promoção da Cidadania Homossexual (BSH) também em 2004, bem como a conquista de outras demandas LGBTQIA no âmbito do direito e da cidadania, incluídas principalmente nas agendas do governo de Lula (Vianna, 2015, p. 798 - 799).

Dentro da perspectiva a respeito da mobilização e organização histórica da população Trans*, foi criado no Brasil recentemente o movimento Transfeminista. Embora a data de seu surgimento não seja um consenso na linha do tempo, sabe-se, entretanto, que o movimento no Brasil foi influenciado pelo Transfeminismo americano através do "Manifesto Transfeminista" de Emi Koyama, publicado em 2001, e seus conhecimentos teóricos vêm sendo desenvolvidos no Brasil pelos últimos cinco a dez anos sob influência da teoria queer internacional nos últimos quinze (Silva, 2016. p. 58).

O "Manifesto Transfeminista" (Koyama, 2001) têm como finalidade trazer a demanda sobre o direito ao respeito e à liberdade, mas não só, também o direito à identidade de gênero, à autonomia corporal e à diversidade e a não sofrer qualquer tipo de discriminação ou violência por declarar e viver segundo sua identidade e vontade.

O nome Transfeminismo mostra uma nítida relação com os movimentos feministas e as lutas contra a desigualdade de gênero, principalmente os que estão alinhados às segunda e terceira ondas do feminismo. A segunda onda feminista busca expandir a compreensão sobre o que é ser mulher na sociedade contemporânea, admitir que o conceito de "mulher" não consegue ser abrangido por aspectos biológicos e deterministas. E a terceira onda do feminismo confronta a ideia de que se pode abarcar universalmente todas as mulheres na sociedade e suas demandas, mas principalmente, vêm questionar os elementos biológicos e sociológicos que vão formar o ser mulher, pensamentos bastante influenciados pelas teorias pós-estruturalistas (Kaas, 2012 apud Silva, 2016, p. 57). 
De acordo com Jesus (2014) apud Silva, (2016, p. 63) "a internet é o canal por excelência de produção, difusão e crítica de informações sobre o pensamento-ação transfeminista". E atualmente é, principalmente, através da internet que diversas trans-ativistas compartilham suas pautas de lutas as quais as populações cisgênero e trans* conseguem ter contato, e suas opiniões quanto às movimentações jurídicas, legislativas e sobre políticas públicas voltadas para pessoas trans*. O que não significa que outras ferramentas de comunicação e organização do movimento tenham sido abandonadas.

Atualmente, importantes organizações para a luta das pessoas trans* estão sendo difundidas, entre elas a ANTRA - Associação Nacional de Travestis e Transexuais, IBRAT- Instituto Brasileiro de Transmasculinidade, ALGBT (Associação Brasileira de Lésbicas, Gays, Bissexuais, Travestis, Transexuais e Intersexos), GRETTA-SP Grupo de Resistência de Travestis e Transexuais Ativistas de São Paulo formado por pessoas participantes do programa TransCidadania, SSEX BBOX - Sexuality out of the box.

Nesse espaço de organização e luta, ativistas como Neon Cunha, Daniela Andrade, Magô Tonhon, Erica Malunguinho, Helena Vieira, Juno Cipolla, Amiel Vieira, Symmy Larrat, Amara Moira entre outras pessoas, tornam-se referência através das lutas que protagonizam em busca de dignidade, direitos e cidadania.

Todo esse histórico de luta e reivindicações do movimento trans ${ }^{*}$ e as diversas opiniões e vivências transmitidas pelas trans-ativistas contribuem para popular e influenciar ideias e ações quanto a criação de políticas, como é o caso do TransCidadania que já se insere como mais um registro e que, por sua vez, também influencia a criação de outras políticas, escrevendo assim mais um capítulo da história do movimento trans* brasileiro.

\subsection{Cidadania e direitos sociais no Brasil}

O conceito de cidadania vem ganhando destaque, não apenas no âmbito político burocrático, mas também para a massa da população, que passou a questionar seu significado, sua efetividade para o cotidiano, e a compreensão da cidadania como um direito universal. 
A discussão sobre a cidadania está tão próxima ao debate acerca dos direitos humanos que esses dois conceitos se reúnem nas instituições oficiais, em alguns estados, como a Secretaria de Direitos Humanos e Cidadania de São Paulo. Há o entendimento que não existe a possibilidade de existência plena de um sem que o outro seja estabelecido, ou seja, sem que um dos dois já esteja efetivado na sociedade. A cidadania, de acordo com Marshall (1967), é desenvolvida a partir dos direitos civis, tendo também ligação com os direitos políticos e sociais. Os direitos sociais - não previstos na declaração de direitos humanos - são conquistas históricas, produtos das relações de conflitos de grupos sociais em um determinado momento. Eles nasceram das lutas de trabalhadores por direito a trabalho e salários iguais e dignos, pelo direito de usufruir da riqueza e dos recursos produzidos pelos seres humanos como moradia, saúde, alimentação, educação, lazer.

De acordo com Benevides (1994):

A cidadania se define pelos princípios da democracia, significando
necessariamente conquistas e consolidação social e política. A
cidadania exige instituições, mediações e comportamentos próprios,
constituindo-se na construção de espaços sociais de lutas
(movimentos sociais, sindicais e populares) e na definição de
instituições permanentes para a expressão política como partidos,
legislação e órgãos do poder público (p.9)

Ou seja, para a autora a cidadania é o reconhecimento dos direitos, na interpretação mais radical sobre a efetivação da democracia como soberania popular, e para que as ações necessárias sejam realizadas, tanto Chaui (1984) quanto Benevides (1994) entendem que a educação é o elemento crucial para o exercício da cidadania ativa. Assim como Benevides (1994), Coutinho (1999) também defende que a entre a cidadania e a democracia ocorre uma inter-relação (p.41):

Cidadania é a capacidade conquistada por alguns indivíduos, ou (no caso de uma democracia efetiva) por todos os indivíduos, de se apropriarem dos bens socialmente criados, de atualizarem todas as potencialidades de realização humana abertas pela vida social em cada contexto historicamente determinado (...) A cidadania não é dada aos indivíduos de uma vez para sempre, não é algo que vem de cima para baixo, mas é resultado de uma luta permanente, travada quase sempre a partir de baixo, das classes subalternas, implicando um processo histórico de longa duração (p.42 ) 
Quando Carvalho (2002) analisa o histórico da cidadania no Brasil em seu livro chamado "Cidadania: o longo caminho", o autor acredita que a cidadania plena ainda está num aspecto ideal, mas que a reivindicação da mesma é um passo importante que vai adquirindo conquistas no decorrer do caminho. Para Carvalho $(2002$, p.9) a cidadania busca fazer com que os direitos civis, políticos e sociais coexistam dentro da sociedade. No caso das pessoas travestis e transexuais, a cidadania trans* conquistada é fruto de um processo histórico de lutas, entre elas o reconhecimento da pessoa trans ${ }^{*}$ como sujeito dos direitos, sem que esta tenha que negar a si mesma, sua identidade, sua sexualidade e quaisquer outras características que julgue que façam parte de si.

A historicidade na conquista da cidadania e outros direitos é fundamental e contribui para o aprofundamento político do debate quanto à travestilidade, transexualidade e cidadania, na organização coletiva e na luta diária das pessoas trans* pelo reconhecimento da sua humanidade. Porém, de acordo com Coutinho (1999) não há cidadania plena sem o exercício também de direitos políticos:

Por exemplo: não há cidadania plena (ou, o que é o mesmo, não há democracia), sem o que Marshall chamou de direitos políticos, isto é, sem a retomada daquela dimensão da cidadania que era própria dos gregos (...) E quais são esses direitos? Além do direito de votar e de ser votado, que é um dos principais meios de assegurar a participação na tomada das decisões que envolvem o conjunto da sociedade, temos ainda - precisamente como condição para que essa participação se torne efetiva - o direito de associação e de organização. Esses direitos, pelo menos até o final do século XIX, foram negados à grande maioria da população, mesmo nos regimes liberais (Coutinho, 1999, p.47).

Ou seja, para o Coutinho (1999) o caminho para a cidadania plena das pessoas trans* também passaria por empoderar esses sujeitos para serem mais que sujeitos passivos dos direitos, mas, se assim compreenderem, sujeitos ativos capazes de participar da vida social e política. A ocupação dos espaços políticos pode assegurar um reconhecimento legal de existência social que facilite a luta por cidadania e o reconhecimento desta como um dever do Estado, ainda que não garanta uma plena materialização dos direitos ou da cidadania per se. 
É pensando sobre cidadania plena e sua efetividade que Berenice Bento vai trabalhar o conceito de cidadania precária relacionando-o as pessoas trans*. Bento (2014, p.165). A autora define a noção de "cidadania precária", na ausência de reflexão e ações no âmbito político e legislativo, que reconheçam e formulem ações para a população trans*. Ela usa como exemplo a criação do nome social que nasce em resposta ao pedido de mudança do registro civil de pessoas trans* ${ }^{*}$ e que aparece como uma conquista parcial, pois não garante que se usufrua de seus direitos plenos. Quando falamos em direitos e cidadania, podemos perceber que estes se aproximariam daqueles descritos pela Carta de Declaração de Direitos Humanos da $\mathrm{ONU}$, e que deveriam ser assegurados a todos e todas. E que a definição de cidadania combinaria o exercício político dos direitos com o acesso a participação da democracia direta, como votante ou votado, de receber educação política, e também ter acesso e usufruir de direitos trabalhistas e civis. Esse exercício da cidadania, seja quanto a promoção de direitos pelo Estado, seja pela consciência que o povo tenha sobre os mesmos, vêm sendo problematizado no que tange ao alcance da democracia e da cidadania.

No Brasil tal discussão ainda se dá em torno dos desafios de consolidar sua democracia recente, pós 1988, como destaca Benevides (1994, p. 7) ao mencionar que a discussão sobre questões da cidadania "permanece associado, na teoria e na prática, e para o bem ou para o mal, à discussões sobre virtualidades e perspectivas da consolidação democrática no Brasil".

Para o propósito desta dissertação, primeiramente me propus a pensar: como um indivíduo pode exercer sua cidadania dentro de uma sociedade de direitos, sem que esta sociedade o reconheça como sujeito? Como pode uma travesti ou um transexual ter acesso à educação, saúde, moradia, voto, ou seja, exercer sua plena cidadania, porém quanto travesti, ou enquanto mulher ou homem trans*, sem que the sejam questionadas coisas referentes à sua identidade, ou seu gênero e genitália? Não são diferentes as perguntas que norteiam o debate que historicamente se segue sobre o tema, uma vez que a ciência, a religião, tem sido utilizada como dispositivos de regulamentação do sexo, sexualidade e do gênero pelo Estado. Esta regulação provocou o apagamento de pessoas transexuais, travestis e intersexo da História, alterando as nossas perspectivas em relação a essas populações em algum momento da formação da cultura e da regulação do sexo, do gênero e das sexualidades. 
$\mathrm{Na}$ ação consciente de não registar, quantificar, estudar e validar outros sexos que fugissem da norma macho e fêmea, - em claro esforço contrário, - existiu e ainda existe, a tentativa de padronizar corpos dentro de um parâmetro do que seria normal e aceitável culturalmente na sociedade. Um dos exemplos mais notáveis da normatização obrigatória é o caso da adequação de bebês intersexos cirurgicamente a um dos sexos ditos normais32 (Vance, 1995; Fausto-Sterling, 2002).

Por conta da padronização compulsória, também mulheres travestis e transexuais e homens trans, sofrem para além da violência física e psicológica. Lidam com o apagamento histórico de suas demandas, com a patologização de sua percepção e convicção de si mesmos enquanto gênero e de sua sexualidade. Têm que se haver com o acesso negado a uma série de direitos, em uma sociedade que reluta em aceita-los e sair de sua cultura padronizada quanto a sexo, sexualidade e gênero. $A$ luta destes grupos é, antes de tudo, por reconhecimento de sua identidade para acesso a direitos básicos como o simples nome que o identifica como sujeito de si.

Se o Estado e a sociedade através de dispositivos regulam o corpo e o comportamento do sujeito social, a religião ainda serve de moralizadora do comportamento, e a ciência ainda patologizar sexualidades, como pode esse mesmo Estado garantir cidadania a "sujeitos politizados" sem que esta seja uma cidadania excluída ou regulada?33.

Se um indivíduo foi marginalizado longo da vida, sem acesso à educação, às vezes até à moradia digna por conta do preconceito e da estima, sem acesso à saúde, vítima da violência organizada do Estado e da sociedade civil, sem usufruir sua cidadania na totalidade, dificilmente conseguirá usufruir de conquistas, somente baseando-se em sua capacidade e mérito. Sua linha de partida está aquém da média do cidadão comum.

\footnotetext{
${ }^{32}$ Sobre esse assunto verificar Anne Fausto-Sterling Dualismo em Duelo.

${ }^{33}$ Sobre o papel do Estado, Soares (2008, p. 201) \# diz que a este cabe assegurar possibilidades realmente iguais para a realização dos direitos referentes às liberdades do indivíduo, ao possibilitar a cada qual satisfazer suas necessidades, segundo sua capacidade, e usufruir das conquistas da sociedade. Soares, não teorizou sobre a questão trans, e sobre os direitos que estes devem exercer dentro da sociedade, ou o papel do Estado quanto a esses. Entendo aqui que é papel do Estado indiscriminante assegurar direitos para todos os indivíduos numa sociedade.
} 
Para esses grupos vulneráveis é necessário que o Estado promova uma política de reparação, de isonomia, para que então indivíduos consigam atingir direitos referentes às liberdades individuais e equidade. Ou seja, não se trata de criar uma dependência do Estado, mas de provocar este a cumprir seus deveres na promoção da isonomia, enquanto o indivíduo faz sua parte trilhando uma jornada de conhecimento, organização política e autonomia.

O histórico do movimento trans* no Brasil nos revela que apesar das dificuldades existentes para sua consolidação, este sempre esteve atento as discussões internacionais que se davam sobre gêneros, identidades e as confusões mantidas pela padronização relacionadas ao entendimento do corpo para além da sexualidade e genitália. E neste ponto a incorporação das discussões teóricas como de Linda Nicholson e Judith Butler no movimento, indicam uma evolução para a construção do respeito à diversidade. Essas arcabouço teórico somado às experiências de vida, de resistência e resiliência das pessoas trans ${ }^{*}$ auxiliaram o movimento a falar da existência de outros corpos e identidades, para além do binarismo feminino/masculino, respaldando as lutas pelos seus direitos individuais e sociais, a fim de romper com a cidadania precária, e seguir rumo a cidadania plena.

\subsection{Definindo direitos e igualdade}

Segundo as diretrizes internacionais da ONU sobre os Direitos Humanos "todo ser humano deve ter seus direitos inalienáveis garantidos, sem que haja discriminações de qualquer ordem, seja ela de gênero, sexualidade, raça, classe ou deficiência"34. É uma declaração que propõe Direitos universais amplos e diversos, principalmente no que se refere à diversidade de grupos que abarca. 
A Declaração 35 dos Direitos Humanos aprovada pela ONU36 (Organização das Nações Unidas), em 1948 é baseada na análoga, Declaração37 dos Direitos do Homem e do Cidadão, de 26 de agosto de 1789. Diretamente ligada à Revolução Francesa e aos valores iluministas, ela foi um primeiro passo para uma série de legislações posteriores que contemplariam a garantia dos direitos humanos. Ela estimulou o surgimento de outros instrumentos que refletissem as necessidades particulares de cada região do mundo moderno.

A Declaração Universal dos Direitos Humanos de 1948, consideraria, ao longo dos seus trinta artigos, o reconhecimento da dignidade como inerente a todos os membros da família humana, bem como estipularia direitos iguais e inalienáveis, tendo como fundamento a liberdade, a justiça e a paz. Ela se focaria nos direitos civis -, que garantiriam a liberdade individual-; e nos direitos políticos, pertinentes à igualdade de participação política, correspondentes aos direitos do cidadão dentro do Estado a que pertence.

As liberdades individuais, que correspondem aos direitos civis da Carta Universal de Direitos Humanos, correspondem aos direitos fundamentais à vida, à liberdade, à propriedade privada e à igualdade perante a lei. Também são contemplados o direito de ir e vir, de dispor do próprio corpo, à liberdade de expressão, a não ser julgado fora de um processo regular, a não ter o lar violado.

Já os direitos políticos se referem à participação do cidadão no governo de sua sociedade, ou seja, a participação no poder (participar de manifestações políticas, organizar partidos, votar e ser votado). O exercício desse direito confere a legitimidade à organização política da sociedade38 (Carvalho, 2002, p. 126).

\footnotetext{
35 Link para declaração Universal dos Direitos Humanos. http://www.ohchr.org/EN/UDHR/Documents/UDHR_Translations/por.pdf ${ }^{36} \mathrm{O}$ Brasil faz parte da ONU como membro fundador.

37 Link para declaração Universal dos Direitos do Homem e Cidadão. http://www.direitoshumanos.usp.br/index.php/Documentos-anteriores-\%C3\%A0-cria\%C3\%A7\%C3\%A3o-daSociedade-das-Na\%C3\%A7\%C3\%B5es-at\%C3\%A9-1919/declaracao-de-direitos-do-homem-e-do-cidadao1789.html

${ }^{38}$ Ver link http://www.planalto.gov.br/ccivil_03/decreto/1990-1994/d0592.htm
} 
Para a ONU, a Carta de Declaração Universal dos Direitos Humanos é inequívoca e que "todos os seres humanos nascem livres e iguais em dignidade e direito", apoiando-se nos princípios fundamentais que são: igualdade e não discriminação. Assim, os Estados que têm como referência a Declaração de Direitos Humanos, teriam o dever de proteger as pessoas LGBTQIA da violação de seus direitos e estender e garantir que os direitos civis e políticos estejam ao alcance de pessoas lésbicas, gays, bissexuais e transgêneros (ONU, 2013).

\subsection{Ordenações da ONU para os membros das Nações Unidas}

Preocupada com a questão LGBTQIA desde o início da década de noventa e buscando contribuir com o debate internacional sobre gênero e diversidade sexual, em 2011 o Conselho de Direitos Humanos da ONU aprovou uma resolução interna demonstrando "grande preocupação" a respeito da violência e discriminação contra indivíduos em função da sua orientação sexual e identidade de gênero.

Em 2012, lançou um livreto com o título "Nascido livres e iguais: Orientação sexual e Identidade de Gênero no Regime Internacional de Direitos Humanos39", com uma referência explícita ao artigo primeiro da Declaração Universal dos Direitos Humanos, que afirma que todos nascem livres e iguais e que, portanto, pessoas LGBTQIA têm os mesmos direitos e proteção estabelecidos na Declaração, pelo menos, em todos os Estados que compõem as Nações Unidas.

De acordo com o novo livreto, formulado com base em outros documentos e tratados internacionais, tais como: Os Relatórios da Relatoria Especial sobre execuções extrajudiciais, sumárias ou arbitrárias; Os Relatórios da Relatora Especial sobre a Violência Contra as Mulheres 40; A Carta de Declaração Universal de Direitos Humanos de 1948 e do Pacto Internacional sobre Direitos Civis e Políticos 41, produzidos pela ONU, todos os Estados membros das Nações Unidas tem as cinco obrigações legais de:

\footnotetext{
${ }^{39}$ Link para cartilha https://nacoesunidas.org/img/2013/03/nascidos_livres_e_iguais.pdf

40 Link para o site com acesso aos relatórios anuais $\mathrm{e}$ outras legislações e convenções. http://www.onumulheres.org.br/referencias/legislacao-e-convencoes/

${ }^{41}$ De acordo com a ONU o pacto Internacional sobre Direitos Civis e Políticos acordado entre os estados membros trata-se de dois Pactos que codificaram a duas séries de direitos esboçados na Declaração Universal: dos direitos civis e políticos e os direitos económicos, sociais e culturais. http://www.cne.pt/content/onu-pactointernacional-sobre-os-direitos-civis-e-politicos
} 
- Proteger as pessoas de violência homofóbica e transfóbica, protegidas por leis criminais contra o ódio, o que inclui relatar atos de violência motivados por ódio referente ao gênero e orientação sexual, conceder asilo a vítima;

- Prevenir a tortura e o tratamento cruel, desumano e degradante às pessoas LGBTQIA, cabendo ao Estado investigar os atos de maus tratos, além de prover treinamento apropriado aos funcionários responsáveis pela aplicação da lei;

- Revogar leis que criminalizam a homossexualidade (as que proíbem relação afetiva e sexual privada entre adultos do mesmo sexo) e leis que submetem pessoas LGBTQIA a exames físicos degradantes e desnecessários em função de determinar a orientação sexual de um indivíduo;

- Proibir a discriminação com base na orientação sexual e identidade de gênero, promovendo leis e assegurando que ela não ocorra. Incluindo nos serviços básicos públicos e promovendo educação e treinamento para prevenir a discriminação e estigmatização de pessoas intersexo e LGBTQIA, como cita o secretário das nações Unidas:

- Proteger as pessoas LGBTQIA e suas liberdades de expressão, de associação e de reunião pacífica.

\subsection{Direitos humanos no Brasil: Da ditadura aos Planos Nacionais de Direitos Humanos}

No Brasil, o debate acerca dos Direitos Humanos, no âmbito do governo federal, se iniciou alguns anos antes da Ditadura Militar de 1964 e o conceito de direitos humanos foi instituído no Direito Brasileiro através Conselho de Defesa dos Direitos da Pessoa Humana (CDDPH) pela lei42 no 4.319 de 16 de março de 1964, alguns meses antes do golpe, e foi criado com a finalidade de ser o guardião dos direitos humanos no país. Durantes os anos de regime militar a noção de Estado Democrático tem um enfraquecimento pela ausência de exercício democrático nas décadas que se seguem, e o debate só seria retomado mais de trinta anos depois. A atualização do conceito se dá na Constituição Federal de 1988, com o entendimento de Direitos Humanos para além das liberdades individuais e dos direitos políticos, já previstos nas constituições anteriores, prevendo como Direitos Humanos também os direitos sociais (Maia, 2012, p. 274-276).

${ }^{42}$ Link para acessar a lei de criação da CDDPH http://www.planalto.gov.br/ccivil_03/leis/1950-1969/L4319.htm 
Segundo a Secretaria de Direitos Humanos da Presidência da República - SDH43, as diretrizes nacionais que orientam as ações do poder público quanto aos Diretos Humanos (PNDH I) só foram estabelecidas em 1996 mais de 10 anos após fim da ditadura. O foco das diretrizes estava na garantia dos direitos civis e políticos, atendendo a agenda e os compromissos internacionais assumidos pelo país como membro fundador da ONU. O PNDH foi revisado e atualizado em 2002, na gestão do então presidente, Fernando Henrique Cardoso, incluindo além dos direitos civis e políticos, os direitos econômicos, sociais e culturais. O documento resultante da revisão foi designado $\mathrm{PNDH}-2$.

Segundo Mello (2012a, p. 408), quando da formulação do PNDH-2, o foco do movimento LGBTQIA estava em pressionar o Poder Legislativo, onde encontrou uma forte resistência. Com o passar dos anos, este foco foi deslocado, passando a priorizar ações de intervenção, pressão e reivindicação sobre o Poder Executivo.

Já a terceira versão, o PNDH-3, foi lançada em 2009, sob a gestão do então Presidente Luís Inácio "Lula" da Silva, incorporando as resoluções da 11a Conferência Nacional de Direitos44 e outras propostas aprovadas em eventos nacionais temáticos promovidos desde o ano de 2003. A principal mudança foi a introdução de conceitos como transversalidade e inter ministerialidade de suas diretrizes para dirigir as ações e objetivos buscando cumprir as perspectivas da universalidade, indivisibilidade e interdependência dos direitos, tal como prevê a Declaração Universal de Direitos Humanos das Nações Unidas.

O PNDH-3 aborda algumas das questões fundamentais da população LGBTQIA, especificamente nos eixos orientadores sobre Desenvolvimento e Direitos Humanos, Universalizar Direitos em um Contexto de Desigualdades, no eixo Segurança Pública, Acesso à Justiça e Combate à Violência e no eixo Educação e Cultura em Direitos Humanos.

Em 2014, a lei $n^{\circ} 12.986$ de 2 de junho45 do mesmo ano, transformou o CDDPH em Conselho Nacional dos Direitos Humanos, com o propósito de ampliar a participação da sociedade civil, uma demanda do Plano Nacional de Direitos Humanos 3 (PNDH3), promovendo diálogo plural e transversal entre os diversos atores sociais.

\footnotetext{
${ }^{43} \mathrm{Em}$ 2017, ele foi vinculado à Secretaria de Direitos Humanos da Presidência da República (SDH/PR). 44 Link para as deliberações da 11a Conferência Nacional de Direitos http://www.ipea.gov.br/participacao/images/pdfs/conferencias/Direitos_humanos_XI/deliberacoes_11_confere ncia_direitos_humanos.pdf

45 Link da lei de criação do Conselho Nacional dos Direitos Humanos. http://www.planalto.gov.br/ccivil_03/_ato2011-2014/2014/lei/l12986.htm
} 


\subsection{Do Nacional para o Municipal: São Paulo entra para o Raibow Cities Network}

Esse entendimento de gestão plural e transversal vai influenciar diretamente outros gestores que possuíam um alinhamento com aquele momento do governo federal, como era o caso do então prefeito de São Paulo Fernando Haddad, que foi Ministro da Educação do Governo do PT em 2005 e 2012.

Como prefeito de São Paulo, o mesmo Fernando Haddad criou a Secretaria Municipal de Direitos Humanos e Cidadania (SMDHC), que possuía como dois eixos principais a afirmação de direitos (Combate à violência, fortalecimento da cultura dos direitos humanos, articulação política para garantia desses direitos) e a participação social como método de gestão

Tais eixos refletem diretamente o alinhamento às diretrizes do PNDH-3, bem como as diretrizes da Declaração de Direitos Humanos da ONU, o que culminou na parceria em 2014 da SMDHC com o Alto Comissariado das Nações Unidas para Direitos Humanos (ACNUDH) para o lançamento no Brasil da campanha LGBTQIA "Livres e Iguais" e a entrada da cidade de São Paulo em 2016 na lista das cidades que possuem políticas públicas para LGBTQIA, da Rainbow Cities Network.

$\mathrm{Na}$ próxima seção do capítulo irei demonstrar como este conjunto de tratados internacionais e nacionais sobre direitos humanos, e em especial para a população trans* ${ }^{*}$ influenciaram ou não nos debates, promoção e garantia de direitos para essa população, seja na esfera legislativa, judiciária e executiva brasileira, e consequentemente nas construções de políticas públicas para a população trans* no Brasil, principalmente na cidade de São Paulo. Porém, antes reflito sobre o papel que a política pública pode cumprir na promoção de direitos e cidadania para a população trans*. 


\section{AS POLÍTICAS PÚBLICAS PARA PROMOÇÃO DA CIDADANIA TRANS*.}

A seguir trataremos das políticas públicas voltadas para a população trans*, dando um aspecto geral sobre o que são políticas públicas, depois tratando da aplicação de tais políticas para garantia da cidadania desta população.

\subsection{Políticas públicas: o que são?}

De acordo com Souza (2006, p. 24), não existe uma definição única para as políticas públicas. Alguns afirmam que o papel das políticas públicas é a solução de problemas sociais pontuais. Outros entendem como as ações dos governos sobre questões públicas para produzir efeitos específicos, influenciando a vida dos cidadãos em geral (Mead, 1995; Lynn, 1980; Peters, 1986) ou ainda, o poder de decisão do governo sobre as questões (Dye,1984).

Para Maria da Graça Rua, políticas públicas têm caráter público não pela amplitude social de sua ação, mas pela soberania de quem as executa (Rua, 1998, p.2). Segundo a Souza (2006, p.24), é a definição de Laswell (1958) uma das mais difundidas e aceita, onde ele sugere que a política pública se dá pela análise de quem ganha o quê, o porquê e que diferença ela faz. 
Entretanto, segundo Souza (2006, p.25), essas definições ainda focam nas ações do governo e não dão conta de enxergar os limites do mesmo, a necessidade da discussão e debate entre governos, a influência de agentes externos que incidem sobre as diversas faces da política pública influenciando o rumo e a tomada de decisão do governo. Os estudos recentes sobre o processo de produção de políticas públicas mostram que não basta observar apenas quem formula a política em si, mas também analisar os subsistemas 46 envolvidos.

Segundo Ball (2001):

A criação das políticas nacionais é, inevitavelmente, um processo de bricolagem; um constante processo de empréstimo e cópia de fragmentos e partes de ideias de outros contextos, de uso e melhoria das abordagens locais já tentadas e testadas, de teorias canibalizadoras, de investigação, de adoção de tendências e modas e, por vezes, de investimento em tudo aquilo que possa vir a funcionar (Mainardes 2001, p.102).

Já Pastorini acredita que:

As políticas sociais apresentam-se como estratégias governamentais de integração da força de trabalho na relação de trabalho assalariado, destinadas a atender problemáticas particulares e específicas apresentadas pela questão social (produto e condição da ordem burguesa), contribuindo para uma subordinação dos trabalhadores ao sistema vigente e reproduzindo as desigualdades sociais decorrentes das diferentes participações no processo de produção (Pastorini, 1997, p.90).

\subsection{História das políticas públicas no Brasil}

\footnotetext{
${ }^{46}$ Os subsistemas são compostos por um número limitado de atores e instituições, geralmente reunidos em grupos mais ou menos coesos, que se especializam e direcionam seus esforços para algumas questões específicas em relação à política. Como resultado da divisão do trabalho e da especialização da burocracia, as áreas funcionais, como educação, saúde, transporte, meio ambiente, entre outras, são compostas de arranjos institucionais e atores que tendem a se aglutinar em torno de programas ou interesses específicos, no que é chamado pela literatura internacional de policy domain. (Capella, 2015 p. 59)
} 
Atualmente, as políticas públicas têm sido reivindicadas por movimentos para suprir demandas de políticas sociais, levando até a um certo desentendimento dos conceitos de cada um, pois, embora toda política social seja uma política pública, nem toda política pública é uma política social. Fato é que as políticas públicas no Brasil se aproximam dos conceitos de desenvolvimento social, aquisição de direitos e cidadania, escopo mais afim às políticas sociais e ao Estado de Bem Estar Social, mas nem sempre foi assim.

No Brasil, é em 1988 com a Constituição Federal que as políticas sociais ganham força, num cenário de redefinição das relações entre Estado e sociedade civil. Com a mobilização e articulação da sociedade civil e com propostas que culminaram na inclusão dos direitos sociais na Constituição. E isto depois de um longo processo de reivindicações e aquisição de políticas sociais que se arrastava desde a República Velha até 1988, no qual o país passou por diversas crises sociais, sem um "aparato jurídico-político que facilitasse a formação mínima de padrões de um Estado de BemEstar Social" (Piana, 2009, p. 42).

\begin{abstract}
A década de 1980 é representativa, na história do Brasil, como o período de abertura democrática do país. O foco das mudanças que permearam o processo de redemocratização da sociedade brasileira foi a garantia dos direitos sociais e individuais e o marco definitivo desse processo, além das eleições diretas para a presidência da República, foi a elaboração da nova Constituição Federal. Esta é sem dúvida a Constituição que melhor refletiu e acolheu os anseios da população, entre eles antigas demandas do movimento de mulheres que, organizado em todo o território nacional, foi um dos líderes da campanha da constituinte, juntamente com o Conselho Nacional dos Direitos da Mulher - CNDM (Vianna \& Unbehaum, 2004, p. 82)
\end{abstract}

Segundo a autora, o país passou na década seguinte por um processo intenso de reformas neoliberais que afetaram diretamente as políticas sociais que estavam voltadas para as populações mais pobres, evidenciando um contraste entre as décadas de 1980 e 1990, onde se teve "uma era repleta de conquistas de direitos sociais, garantidos pela nova Constituição, outra marcada pelas reorientações políticas sob a ótica neoliberal” (Vianna \& Unbehaum, 2004, p. 82) 
$\mathrm{Na}$ América Latina e demais países de desenvolvimento recente da democracia, as políticas públicas têm ganhando destaque. Esse destaque é impulsionado por fatores como a adoção de políticas restritivas de gastos e menor interferência do Estado (tanto em políticas econômicas quantos em políticas sociais), adoção de comportamentos equilibrados entre despesa e receita e a incapacidade de formar coalizões políticas que respondessem a questões como o desafio de impulsionar o desenvolvimento econômico e ao mesmo tempo promover a inclusão social.

\subsection{Desafios na implantação de políticas públicas}

A implementação das políticas públicas esbarra em obstáculos que serão tratados a seguir.

\subsubsection{Desinformação e religião}

A sociedade brasileira encara, de forma geral, a implantação de políticas públicas, principalmente as de caráter social, de público-alvo e de alcance direcionados como uma forma de assistencialismo, ou de favorecimento com vistas ao processo de voto, o chamado curral eleitoral. Há uma interpretação de que as políticas públicas deveriam ser de alcance e benefício universal, não podendo, portanto, privilegiar um setor específico. Então, quando uma política pública de âmbito social é desenhada para um grupo específico, como é o caso das políticas para travestis e transexuais, uma das primeiras barreiras a serem rompidas é a deslegitimação dessas políticas por preconceito e desinformação.

As políticas públicas que abordam questões de gênero e sexualidade ainda esbarram no conservadorismo, no moralismo, e no preconceito que impedem que grande parte da sociedade reconheça a necessidade de solucionar as desigualdades e violências a que a população LGBTQIA está sujeita. Especialmente em países de forte tradição religiosa, -o Brasil é o maior país católico e o maior país neopentecostal do mundo-, debates que tratam de sexo, gênero, família, reprodução estão condicionados a processos dolorosos e burocráticos para serem efetivados, ainda que os agentes dos movimentos sociais se esforcem para debater essas questões. 
Para Souza (2006, p. 26), a política pública é a ferramenta que possibilita aos governos traduzirem "seus propósitos em programas e ações, que produzirão resultados ou as mudanças desejadas no mundo real". Por isso, a política pública pode e deve servir ao propósito de reparar o descaso histórico e violência para com a população LGBTQIA. Assim como pode apoiar, expandir e ampliar as iniciativas que contemplam as demandas dessa população, combatendo a morosidade observada nos demais âmbitos e instituições do próprio Estado.

\subsection{Modelos de Políticas Públicas}

Quando se fala em políticas públicas, alguns autores desenvolveram modelos explicativos para ajudar a explicar melhor como e por que algumas gestões fazem ou deixam de fazer alguma ação que repercutirá na sociedade. (Souza 2006, p.28)

\subsubsection{O Ciclo de Políticas Públicas de Ball}

Segundo Mainardes (2006) um dos modelos utilizados para entender as políticas públicas por exemplo, é o "Ciclo de Políticas Públicas" desenvolvido por Ball. O Ciclo de Políticas Públicas é constituído de um ciclo contínuo de cinco contextos ligados e inter-relacionados sem dimensão temporal nem sequencial ou linearidade: Contexto de influência, produção de texto, prática, resultados/efeitos e contexto da estratégia política (Mainardes, 2006; Mainardes \& Marcondes, 2009).

De maneira geral, o contexto de influência está relacionado com o momento inicial e o espaço onde fica evidente as disputas pela construção da narrativa e definições da política pública, onde os "discursos políticos são construídos", ganhando legitimidade na base política.

O contexto de produção de texto está ligado ao discurso e o como ele é formado, e como o discurso sobre as demandas, necessidades e políticas, bem como suas soluções e proposições, será construído.

No contexto de influência, por exemplo, o contexto de produção de texto ganha formas de textos legais oficiais, pronunciamentos, comentários formais ou informais etc, resultados de disputas e acordos em um espaço de diálogo. 
O contexto de prática é "onde a política produz efeitos e consequências", ou seja, é o momento em que as políticas serão implementadas e/ou recriadas.

O contexto de resultados ou efeitos preocupa-se com "questões de justiça, igualdade e liberdade individual", é o momento em que as políticas são analisadas por seu impacto e efeitos, mais do que por números e resultados.

E por fim o contexto de estratégia política que é "a identificação de um conjunto de atividades sociais e políticas que seriam necessárias para lidar com as desigualdades criadas ou reproduzidas pela política investigada".

A política pública pode ser uma forte aliada na luta pelos direitos humanos, e a sua análise é fundamental para garantir uma correta imagem da eficiência e eficácia da mesma, garantindo assim apoios dos mais diversos setores da sociedade, e consequentemente melhoria e ampliação dos programas avaliados e uma possível reprodução destes em outros lugares com cenários políticos semelhantes.

A seguir destacarei as ações que ganharam terreno no âmbito governamental, abrangendo os 3 poderes, que são resultado da luta histórica do movimento trans*.

\subsection{Na trilha da cidadania: passos da luta trans* nos 3 poderes}

No capítulo anterior, relatei como o movimento LGBTQIA no Brasil se estruturou em resposta à epidemia da AIDS. À época rapidamente associada pelas campanhas de saúde à população não heterossexual, a infeção por HIVIAIDS era conhecida por atacar apenas a comunidade LGBTQI e o discurso geral da sociedade era de estigma, culpabilização e setores religiosos até falavam em castigo divino. A despeito da grande resistência e preconceito, a pressão internacional, e nacional, pela busca por uma cura, e por estratégias de prevenção deram resultado. Este primeiro debate sobre saúde possibilitou a entrada da pauta da prevenção na agenda política na década de 1980 , o que, ainda que de forma limitada, foi fundamental para promover, na esfera pública, a discussão sobre a pluralidade de expressões da sexualidade, reivindicada desde os anos 1960 pelos movimentos feministas, e de diversidade.

A pressão realizada pelos movimentos LGBTQIA no cenário internacional, reivindicando a garantia de direitos para essa população, contribuiu para retirada da homossexualidade da lista de patologias mentais pela APA em 1973, fato que repercutiu no Brasil, onde tratamentos que prometiam a "cura" da homossexualidade passaram a ser condenados pelo Conselho Federal de Psicologia. 
A inclusão das pautas do movimento LGBTQIA na agenda política do Governo Brasileiro tais como o direito ao registro social e civil, tratamento especializado em equipamentos públicos de saúde, educação, empregabilidade, são reflexo da importância do debate sobre diversidade sexual, direitos civis e sociais, fruto de diversas ações reivindicatórias dos movimentos LGBTQIA.

\subsubsection{Judiciário e diversidade}

Importantes conquistas no campo das reivindicações democráticas para a comunidade LGBTQIA tem sido alcançada no Brasil na última década. E é na esfera do poder Judiciário é onde podemos observar os maiores avanços.

Em 2011 uma decisão realizada pelo judiciário brasileiro sobre uma união estável contribuiu na aprovação da resolução 175, de 14 de maio de 2013 do CNJ47 (Conselho Nacional de Justiça), determinou-se que os cartórios de todo o país pudessem celebrar casamentos civis de pessoas do mesmo sexo.

Além desta vitória histórica gostaria de destacar alguns marcos nacionais importantes ordenado pela Justiça Federal que determinava o custeio das cirurgias de redesignação de genitália48 ao Sistema Único de Saúde (SUS) em todo o país (2008), a determinação Ministério da Fazenda que, através de uma portaria, estendeu o direito de declaração conjunta para casais homoafetivos49 (2010), a ação da Procuradoria Geral da República ingressando com ADIN (Ação Direta de Inconstitucionalidade) no STF com o objetivo de permitir que transexuais pudessem mudar seu nome no registro civil independente da realização da cirurgia de mudança de genitália50 em (2009), (aprovado recentemente, 01 de Março de 2018), a decisão compreende ainda que essa mudança de registro seja dada pelo administrativo, sem a necessidade da interferência do Judiciário, que se colocou como a favor do veredito.

47 Links para resolução sobre casamento civil de pessoas do mesmo sexo biológico. http://www.cnj.jus.br/images/imprensa/resolu\%C3\%A7\%C3\%A3o_n_175.pdf

http://www2.stf.jus.br/portalStflnternacional/cms/destaquesNewsletter.php?sigla=newsletterPortallnternacional Destaques\&idConteudo=238515 e resolução http://www.cnj.jus.br/busca-atos-adm?documento=2504

${ }^{48}$ Link para resolução sobre o custeio de cirurgias realizadas pelo SUS para redesignação de genitália http://www.brasil.gov.br/cidadania-e-justica/2015/03/cirurgias-de-mudanca-de-sexo-sao-realizadas-pelo-susdesde-2008

${ }^{49}$ Link sobre a decisão de declaração conjunta ao Ministério da Fazenda http://www.pgfn.fazenda.gov.br/revistapgfn/revista-pgfn/ano-i-numero-i/revista.pdf

50 Apesar da ação ser desde 2009, em 2016 a decisão foi regulamentada. http://agenciabrasil.ebc.com.br/direitos-humanos/noticia/2016-10/cirurgia-de-troca-de-sexo-nao-e-obrigatoriapara-mudar-nome-no e ver http://www.conjur.com.br/2009-jul-22/pgr-transexuais-possam-mudar-nomemesmo-operacao 
Há, ainda, outros marcos regionais importantes como as constituições dos estados de Mato Grosso e Sergipe51 que explicitamente proíbem discriminação contra orientação sexual em (1989); o projeto de lei no 115152 , submetido pela então deputada, Marta Suplicy em São Paulo, relativo à união estável de pessoas do mesmo sexo em (1995); no Rio Grande do Sul, a determinação aos cartórios de Títulos e Documentos que registrem uniões homoafetivas53 em (2004); a vigência da Lei Maria da Penha (Lei no $11.340 / 0654)$, que nos artigos $2^{\circ}$ e $5^{\circ}$ reconhece uniões homoafetivas femininas quando menciona que merece proteção também a mulher que sofre violência doméstica de sua companheira em (2006) e, mais recentemente, incorporar também violências contra Travestis e Transexuais

\subsubsection{A vez do Executivo}

No Executivo, começo destacando o PNDH-3 como um importante passo no que diz respeito aos direitos humanos e cidadania. O Plano Nacional de Direitos Humanos, terceira versão (PNDH-3), ao abordar o "Desenvolvimento e Direitos Humanos", afirma que ambos conceitos estão intimamente ligados. Isso representaria um desafio, uma vez que o plano não encararia "desenvolvimento" apenas a partir do crescimento econômico do país com base no Produto Interno Bruto (PIB), mas também em fatores como a distribuição justa de riqueza, possibilitando o bem-estar centrando a discussão principalmente em inclusão social e em garantir o exercício amplo da cidadania.

\footnotetext{
${ }^{51}$ Link sobre a proibição da discriminação em virtude da orientação sexual nas Constituição do Estado de Mato Grosso https://www.tjms.jus.br/webfiles/producao/SPGE/revista/20161213172729.pdf ; e Constituição do Estado de Sergipe, artigo $3^{\circ}$ link https://www2.senado.leg.br/bdsf/bitstream/handle/id/70454/SE-EC41.pdf?sequence $=1$ e na Lei Orgânica do Distrito Federal, artigo $2^{\circ}$, link http://www.fazenda.df.gov.br/aplicacoes/legislacao/legislacao/TelaSaidaDocumento.cfm?txtNumero=0\&txtAno $=0 \&$ txtTipo $=290 \&$ txtParte $=$.

52 Link para o projeto de Lei que atualmente foi retirado de pauta. http://www.camara.gov.br/proposicoesWeb/fichadetramitacao?idProposicao=16329

53 Jornal do Commércio/RJ, Seção: Direito \& Justiça, 5/3/2004, p.B-7 , link http://www.irib.org.br/boletins/detalhes/2779

54 Uma das mais importantes leis no Brasil que trata sobre a violência contra mulher. Link http://www.planalto.gov.br/ccivil_03/_ato2004-2006/2006/lei/111340.htm
} 
No PNDH-3 existe uma relação forte entre os termos cidadania e direitos humanos ligados a direitos sociais. No caso do Brasil, e de países com características socioeconômicas semelhantes, com profunda desigualdade social, um passado escravocrata, recente democracia, que busca consolida-la entre períodos de ditaduras, um golpe de estado e outro, torna-se quase impossível pensar em liberdades individuais sem que o social esteja plenamente garantido.

A partir deste plano, e das resoluções internacionais citadas, entendo como uma função do Estado garantir o acesso ao trabalho, à saúde, à educação, à alimentação, à vida cultural, à moradia adequada, à previdência, à assistência social e a um meio ambiente sustentável. Assim como é dever do Estado promover e estimular políticas públicas que visem a redução das desigualdades sociais por meio de ações concretas, entre elas a transferência de renda. Esse ponto fica explícito no PNDH-3, na Diretriz 4, do Objetivo estratégico I, sobre "Implementação de políticas públicas de desenvolvimento com inclusão social" nos itens:

\footnotetext{
Ampliar e fortalecer as políticas de desenvolvimento social e de combate à fome, visando a inclusão e a promoção da cidadania, garantindo a segurança alimentar e nutricional, renda mínima e assistência integral às famílias. [...]

k) Integrar políticas sociais e de geração de emprego e renda para o combate à pobreza urbana, em especial de catadores de materiais recicláveis e população em situação de rua (Brasil,2010).
}

Parte-se, então, do princípio que a promoção de cidadania perpassa pelo direito ao registro civil, alimentação adequada, terra e moradia, trabalho decente, educação, participação política, cultura, lazer, esporte e saúde e o plano ainda destaca que o combate a discriminação é necessário, mas, que para ser efetivo deve estar aliado com ações e políticas compensatórias que acelerem a construção da igualdade, estimulando e incluindo efetivamente os grupos socialmente vulneráveis (Brasil, 2010). 
O PNDH-3 também estabelece relação com as diretrizes elaboradas no Plano Nacional de Educação em Direitos Humanos (PNEDH), que sugere ações a serem adotadas nas esferas nacional, estadual, distrital e municipal. Entre as tantas diretrizes, ele defende a educação aliada aos direitos humanos, refletindo o sentimento de convivência pacífica com os diversos atores da sociedade e o combate o preconceito desde a infância. Para tanto, inclui o estudo temático de gênero e orientação sexual e das culturas indígenas e afro-brasileiras entre as disciplinas de ensino fundamental e médio, além de recomendar a formação e educação continuada em Direitos Humanos com recortes de gênero, relações étnico-raciais e de orientação sexual em todo o serviço público.

A realização das primeiras Conferências Nacionais LGBTQIA em 2008, 2011 e 2015, ajudaram na elaboração de outros espaços de desenvolvimentos de políticas públicas que resultaram em documentos por parte do Executivo, como o Plano Nacional de Promoção da Cidadania e Direitos Humanos de LGBTQIA e o Programa Brasil sem Homofobia55.

Segundo o Plano Nacional de Promoção de Cidadania e Direitos de LGBTQIA, seus eixos estratégicos visam a promoção da cooperação federativa; articulação e fortalecimento de redes sociais; articulação com outros poderes; cooperação internacional e a gestão da implantação sistêmica da política para LGBTQIA. Ou seja, - Plano Nacional determina a integração da política de promoção da cidadania e defesa dos direitos humanos de LGBTQIA com as demais políticas públicas nacionais, numa articulação com outros poderes para a promoção da cidadania e defesa dos direitos humanos desta população.

Segundo Mello (2012b, p.408) no âmbito executivo, a partir do Governo Lula, os movimentos sociais encontraram uma maior receptividade, possibilitando a elaboração de um conjunto de iniciativas, tais como:

- Criação do Brasil Sem Homofobia (BSH) em 2004;

- Realização de Conferência Nacional de Gays, Lésbicas, Bissexuais, Travestis e Transexuais56 em 2008, 2011 e 2016;

\footnotetext{
${ }^{55}$ Link para as diretrizes do programa http://bvsms.saude.gov.br/bvs/publicacoes/brasil sem homofobia.pdf ${ }^{56}$ A Conferencia realizada em 2008 teve como tema: Direitos humanos e políticas públicas: o caminho para garantir a cidadania de Gays, Lésbicas, Bissexuais, Travestis e Transexuais, Link para noticia http://www.seppir.gov.br/portal-antigo/noticias/ultimas noticias/2008/06/docfinal LGBT e anais da conferência http://www.sdh.gov.br/sobre/participacao-social/cncd-Igbt/conferencias/anais-1a-conferencia-nacional-lgbt-2
} 
- Lançamento do Plano Nacional de Promoção da Cidadania e Direitos Humanos de Lésbicas, Gays, Bissexuais, Travestis e Transexuais PNDCDH-LGBTQIA57, 2009;

- Publicação do decreto que cria o Programa Nacional de Direitos Humanos 3 PNDH 3, 200958;

- Criação da Coordenadoria Nacional de Promoção dos Direitos de LGBTQIA, no âmbito da Secretaria de Direitos Humanos, 2010 59 ; e

- Implantação do Conselho Nacional LGBTQIA, em 201060, com representação paritária do governo federal e da sociedade civil.

- Lançamento do Sistema Nacional de Enfrentamento à Violência contra LGBTQIA e Promoção de Direitos (2013) ${ }^{61}$.

Entretanto, apesar de uma relativa abundância de documentos governamentais e de eventos que proporcionam interlocução entre governo e sociedade civil, o grande desafio é transformar as incipientes políticas públicas, gestadas ao longo dos últimos anos, especialmente a partir de 2004, em políticas efetivas de Estado. Tais políticas devem ser perenizadas e devem ajudar a superar as incertezas decorrentes da falta de um marco legal de combate à homofobia e de promoção da cidadania LGBTQIA. Embora as decisões judiciais tenham tido relativo avanço no reconhecimento de direitos, há ainda a dificuldade de se construir uma legislação na área, e esta é uma reivindicação da sociedade civil, tornar o plano, realidade: "na atualidade, o movimento social exige do poder público uma atuação mais ampla e permanente, que não esteja limitada às opções do governo da vez, mas que sejam políticas públicas efetivas" (Mello et al, 2014, p.303).

As produções de cartilhas, anais de conferências, leis, bem como o Plano Nacional de Direitos Humanos 3, encontram-se disponíveis no site da SDH62 (Secretaria especial de Direitos Humanos), e, apesar, das incertezas que atualmente cercam os rumos dos direitos humanos quanto às pessoas LGBTQIA a nível Federal, eles ainda são os únicos respaldos oficiais para as lutas das pessoas LGBTQIA quanto a promoção de seus direitos.

\footnotetext{
${ }^{57}$ Link para o PNDCDH-LGBT http://www.arco-iris.org.br/wp-content/uploads/2010/07/planolgbt.pdf

58 Link para documento de criação do decreto de criação do PNDH-3 http://www.planalto.gov.br/ccivil_03/_ato2007-2010/2009/decreto/d7037.htm

59 Link para decreto de criação da Coordenadoria Nacional de Promoção dos Direitos de LGBTT,http://www.planalto.gov.br/ccivil_03/_Ato2007-2010/2010/Decreto/D7256.htm

${ }^{60}$ Link para o decreto de criação do Conselho Nacional LGBTT http://www.planalto.gov.br/ccivil_03/_Ato20072010/2010/Decreto/D7388.htm

${ }^{61}$ Sobre o lançamento do sistema http://www.sdh.gov.br/noticias/2013/junho/sdh-lanca-sistema-nacional-depromocao-de-direitos-e-de-enfrentamento-a-violencia-lgbt

${ }^{62}$ Link para acesso ao site do SDH http://www.sdh.gov.br/
} 
Infelizmente, essas conquistas ainda não foram suficientes para estagnar os números da violência e o descaso contra travestis e transexuais. Porém, eles servem como uma luz que se acende para mostrar que pessoas LGBTQIA existem, que estão reivindicando seus direitos há anos e seguem sofrendo com a cidadania precária, como aponta Bento (2014, p. 167).

\subsubsection{Legislativo: Violência, legislação e cidadania}

Previsivelmente, a inserção da questão da AIDS na agenda política governamental, e mesmo os planos e cartilhas, não significaram que as demandas da população LGBTQIA assumissem um lugar relevante entre as políticas de Estado de modo geral. A questão da violência contra pessoas trans* reflete ainda o quanto o setor legislativo está atrasado em responder às demandas dessa população, em comparação ao demais setores como o judiciário e executivo.

A violência sofrida por pessoas LGBTQIA é tratada com negligência nos debates sobre políticas públicas. No caso do Brasil, não existe uma ferramenta oficial do governo que registre e quantifique os casos de violência e morte impulsionados pela fobia a pessoas travestis e transsexuais, situação que se agrava porque as ocorrências não são sequer registradas pelas delegacias como crime à pessoa LGBTQIA ou relacionadas à sua orientação sexual e identidade de gênero, o que torna difícil a quantificação e gera subnotificação.

O Disque denúncia63, ou Disque Direito Humanos (Disque 100) - principal canal de atendimento da Ouvidoria Nacional de Direitos Humanos, - é responsável por recolher cerca de $90 \%$ das denúncias do canal. Em 2015, o órgão divulgou um aumento de $94 \%$, em relação ao ano anterior, de denúncias de violação aos direitos humanos contra a população LGBTQIA. Mesmo com esse cenário, o projeto de lei que visava criminalizar a homofobia, PLC 122, foi rejeitado e não se fala em outras propostas. De acordo com a ONU:

${ }^{63}$ Link sobre o disque denúncia http://www.brasil.gov.br/cidadania-e-justica/2016/04/denuncias-de-violacao-dedireitos-Igbt-teve-aumento-de-94-em-2015 
atitudes homofóbicas profundamente enraizadas, muitas vezes combinadas com uma falta de proteção jurídica adequada contra a discriminação em razão de orientação sexual e identidade de gênero, expõem muitas pessoas LGBT, de todas as idades e em todas as regiões do mundo, à violações evidentes de seus direitos humanos. Elas são discriminadas no mercado de trabalho, nas escolas e nos hospitais, e maltratadas e rejeitadas por suas próprias famílias. Nas ruas das cidades ao redor do mundo, são as escolhidas para o ataque físico - espancadas, agredidas sexualmente, torturadas e mortas. Em cerca de 76 países, leis discriminatórias criminalizam relações consensuais privadas entre pessoas do mesmo sexo - expondo indivíduos ao risco de serem detidos, acusados e presos (ONU,2013).

Ou seja, para a ONU em sua cartilha "Livres e Iguais...", as obrigações legais dos Estados em proteger os direitos de pessoas LGBTQIA estão bem estabelecidas no regime internacional de direito com base na Declaração Universal dos Direitos Humanos e nos tratados internacionais sobre o tema"64; Por isso ações que visem a proteção e segurança da pessoa transexual e travesti devem ser tratadas como prioridades também na esfera legislativa. No entanto, esta demanda ainda caminha a pequenos e dificultosos passos.

No município de São Paulo, alguns avanços quanto ao debate de promoção dos direitos humanos e adaptação às diretrizes estabelecidas pelo Governo Federal, mas também pela ONU, estão sendo implementadas. É o caso da Secretaria Municipal de Direitos Humanos e Cidadania, e o programa TransCidadania que será apresentado a seguir e que é um esforço consciente do setor executivo da Cidade de São Paulo, para enfrentar junto com a sociedade e comunidade trans* as diversas formas de violência e discriminação que essas pessoas estão sujeitas, através de ações educacionais e de conscientização cidadã. 


\section{O PROGRAMA TRANSCIDADANIA}

Existe um Luciano antes do TranscCdadania e outro depois do TransCidadania. (Medeiros, 2016.)

\subsection{0 projeto}

O TransCidadania é um programa social desenvolvido pela Prefeitura de São Paulo durante gestão do Prefeito Fernando Haddad. Criado pelo Decreto $n^{\circ} 55.874$, de 29 de janeiro de 201565 , ele foi realizado a partir de parcerias entre a Secretaria Municipal de Direitos Humanos e Cidadania (SMDHC) e a Secretaria Municipal do Desenvolvimento, Trabalho e Empreendedorismo (SMDTE).

Esse programa fez parte das metas do Plano de Governo Haddad Prefeito 2012: "Um tempo novo para São Paulo"66, no qual no capítulo chamado "Direito à Diversidade Sexual", o prefeito afirmava que pretendia colocar em prática o Plano Municipal de Combate à Homofobia 67, elaborado nos anos de 2008 e 2011 durante as Conferências Municipais que previam propostas quanto às questões de direitos e cidadania à população LGBTQIA.

\footnotetext{
65 Link para decreto criação do TransCidadania http://www3.prefeitura.sp.gov.br/cadlem/secretarias/negocios_juridicos/cadlem/integra.asp?alt=30012015D\%2 0558740000

66 Link para o Plano de Gestão do Prefeito Fernando Haddad http://estaticog1.globo.com/2015/09/10/Programa_de_Governo_Haddad.pdf

67 Link para Planos municipais de combate a Homofobia http://www.prefeitura.sp.gov.br/cidade/secretarias/upload/direitos_humanos/participacao_social/Relatorio\%20 Final\%20da\%20I\%20Conf\%20Munic\%20LGBT.odt. http://www.prefeitura.sp.gov.br/cidade/secretarias/upload/direitos_humanos/participacao_social/Propostas\%2 0da\%20II\%20Conferencia\%20Municipal\%20LGBT.doc. ,
} 
O plano de governo da Prefeitura de São Paulo de 2012 previa ações quanto à saúde, educação, segurança, cultura, nome social, criação de Centros de Referência e Combate à Homofobia (com advogados, psicólogos e assistentes sociais), equipar a Coordenadoria da Diversidade Sexual (CADS) de recursos humanos e orçamentários, criar vinculado ao CADS uma unidade móvel para atendimento da população LGBTQIA, fortalecer o Conselho Municipal LGBTQIA e melhorar o mapeamento de ocorrências homofóbicas no município de São Paulo.

Seguindo a orientação da Câmara Municipal de São Paulo - elaborada em 2008, após uma mobilização da sociedade civil que exigiu um Programa de Metas de todo prefeito após sua posse68- em 2013 foi apresentado o Programa de Metas 2013-2016 do Prefeito Fernando Haddad, que pode ser entendido como a consolidação do programa de governo: Um tempo Novo para São Paulo69.

Prometendo reduzir a realidade desigual e desequilibrada da população de São Paulo, o Programa de Metas 2013-2016 se propunha a governar a cidade de maneira transversal e realizar seu plano através de 100 metas, que foram agrupadas em três eixos temáticos que se desdobram em 21 objetivos estratégicos. Os eixos temáticos foram: 1 - Compromisso com os Direitos Sociais e Civis, 2 - Desenvolvimento Econômico Sustentável com Redução das Desigualdades e 3 - Gestão Descentralizada, Participativa e Transparente.

Neste plano de gestão, no eixo 1 "Compromisso com os Direitos Sociais e Civis", o objetivo 10 refere-se a "Promover uma cultura de cidadania e tolerância, reduzindo as manifestações de discriminação de todas as naturezas". Dentro desse objetivo encontram-se as seguintes metas:

\footnotetext{
68 Link para a ementa da Lei Orgânica do Municipio de São Paulo http://www.nossasaopaulo.org.br/portal/emenda
${ }^{69}$ Link para todas as versões do plano de meta de Fernando Haddad, a primeira versão e a última versão, chamada de versão participativa. http://www.prefeitura.sp.gov.br/cidade/secretarias/gestao/programa de metas/index.php?p=149999
} 


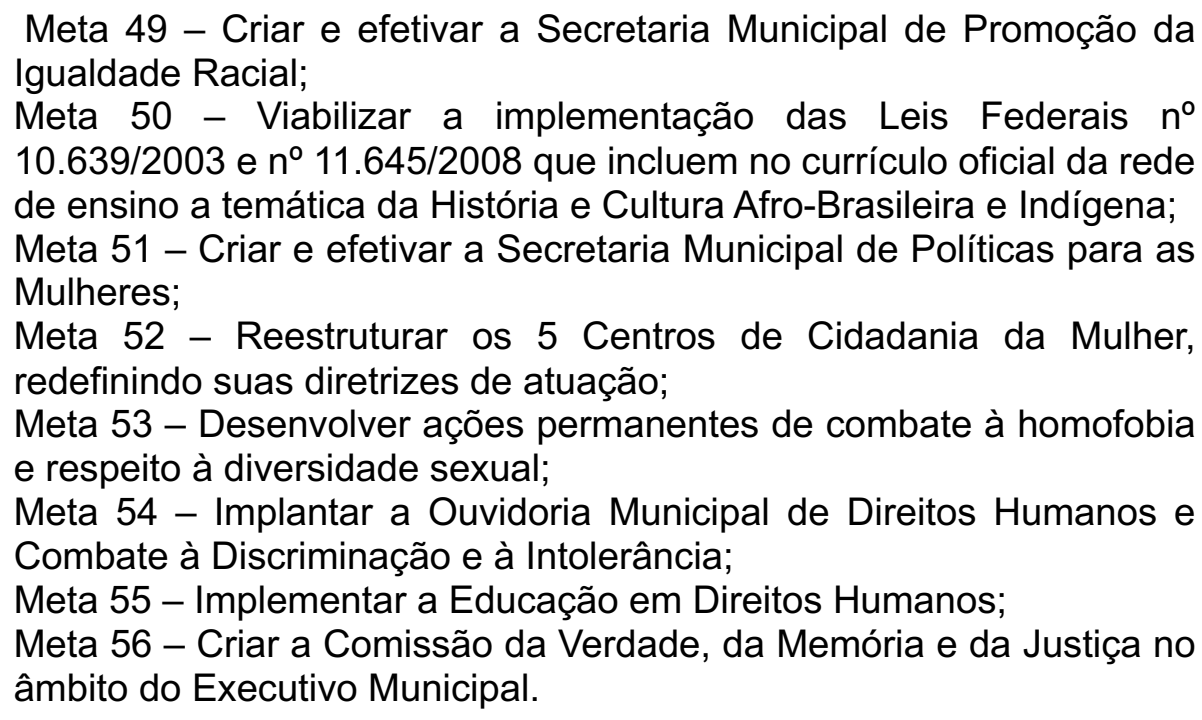

De acordo com o ex-Coordenador Adjunto de Políticas LGBTQIA, André Luiz, o programa TransCidadania foi idealizado no esforço de cumprir a meta 53, junto das demais iniciativas previstas no programa de gestão, como o Centro de Referência em Direitos Humanos na Prevenção e Combate à Homofobia $(\mathrm{CCH})$, Unidade Móvel de Cidadania LGBTQIA e o Centro de Referência em Direitos Humanos - Coordenação Balcão de Atendimentos.

Quanto ao plano de gestão do então Prefeito Fernando Haddad percebo uma forte intenção de estar alinhado às diretrizes e tratados internacionais ao Direitos Humanos da ONU ligados às pessoas LGBTQIA, e as Diretrizes traçadas pelo Governo Federal ao qual Fernando Haddad esteve ligado enquanto Ministro da Educação antes de se tornar prefeito de São Paulo. Outros pontos de intencionalidade são relativos à participação social como método de gestão, transversalidade e a ideia de pertencimento à cidade enquanto espaço de exercício de cidadania, foram utilizados para nortear a criação de novos instrumentos a partir da junção de ferramentas já existentes no município. 
Como por exemplo, a nova Secretária Municipal de Direitos Humanos e Cidadania (SMDHC) que foi criada a partir do Decreto Municipal $n^{\circ} 53.685$, de 2 de janeiro de 201370, unificando as já existentes Comissão Municipal de Direitos Humanos (criada em 2002) e a Secretaria Municipal de Participação e Parceria (criada em 2008). Ganhando força normativa pela Lei Municipal $n^{\circ} 15.764$, de 27 de maio de 201371, através da Lei Municipal de Reforma Administrativa72.

De acordo com a prefeitura, o objetivo da SMDHC é o aprimoramento das políticas públicas que visam o fortalecimento e garantia dos direitos humanos, o incentivo à participação social através de mecanismos tradicionais (conferências, conselhos e audiências públicas) e formas inovadoras e não institucionais, pelo diálogo social (promovido através das novas mídias) e a ocupação do espaço público, ou seja, sua política principal é fomentar a participação social como método de gestão.

\subsection{0 processo}

A partir da SMDHC foram criados três macros coordenação, divididas em eixos de atuação: a Coordenadoria de Promoção e Defesa de Direitos Humanos, a Coordenadoria de Participação Social e Gestão Estratégica e a Supervisão Geral de Administração e Finanças.

A SMDHC abrangeu em seu projeto duas áreas consideradas fundamentais para o cumprimento das metas da secretaria: a de Promoção e Defesa de Direitos Humanos e a de Participação Social como método de gestão. Com isso, pretendeu-se melhorar a articulação e a gestão transversal das políticas de Direitos Humanos e Cidadania da Cidade de São Paulo. Cada uma das três coordenações se desdobrou em outras coordenações específicas dependendo de suas áreas de atuação.

\footnotetext{
70 Link para decreto de criação da nova secretaria SMDHC http://www3.prefeitura.sp.gov.br/cadlem/secretarias/negocios_juridicos/cadlem/integra.asp?alt=02012013D\%2 0536850000

71 Link para lei de criação da nova secretaria SMDHC http://www3.prefeitura.sp.gov.br/cadlem/secretarias/negocios_juridicos/cadlem/integra.asp?alt=28052013L\%2 0157640000

72Lei Municipal de Reforma Administrativa http://www.camara.sp.gov.br/1132-2/
} 
À Coordenadoria de Promoção e Defesa de Direitos Humanos coube englobar algumas pastas já existentes e outras que foram criadas. Desta forma, ficou composta pelas seguintes coordenações: Educação em Direitos Humanos, Promoção do Direito à Cidade, Direito à Memória e à Verdade, Políticas para Juventude, Políticas para a População em Situação de Rua, Políticas para Criança e Adolescente, Políticas para LGBTQIA, Políticas para Idosos e Políticas para Migrantes.

Ficou a cargo da Coordenação de Políticas para LGBTQIA, da SMDHC, articular as ações que satisfariam a meta 53 do Plano de Metas 2013-2016, que diz respeito a "Desenvolver ações permanentes de combate à homofobia e respeito à diversidade sexual". As ações planejadas foram:

- Campanha com veiculação na grande mídia, com o objetivo de promover o respeito e a cidadania da população LGBTQIA e combater a homofobia.

- Centros de Referência e Combate à Homofobia

- Atividades de formação continuada na rede municipal de ensino.

- Promoção de atividades de combate à homofobia em espaços públicos.

- Apoio para a realização da Paradas do Orgulho LGBTQIA, uma das maiores do mundo, organizado pela APOGLBT (Associação da Parada do Orgulho LGBTQIA).

- Elaboração do Programa TransCidadania ${ }^{73}$.

- GTI para saúde integral da população LGBTQIA (com SMS)

- Revitalização do Largo do Arouche: Subprefeitura Sé

- Centros de Referência e Combate à Homofobia: rede de proteção à vítima de violência homofóbica e de promoção à cidadania LGBTQIA

Com isso, estava dada a largada para a elaboração do Programa TransCidadania. Pioneiro no Brasil e na América Latina enquanto prática neste modelo de gestão pública, e ousado, diante do momento de negação de direitos para pessoas Trans* que passava o país. Dois anos após esses primeiros passos o programa foi inaugurado no dia 29 de janeiro de 2015 como relata em entrevista a então coordenadora do programa TransCidadania, Symmy Larrat:

${ }^{73}$ Destaque em negrito da pesquisadora. 
Quando eu cheguei aqui, eu tinha uma nota conceitual na minha mão e alguns diálogos, mas o prefeito disse: esse é o Programa da gestão e essas portas se abriram e a gente conseguiu pactuar fluxos. Tinha um diálogo, as pessoas sabiam do Programa, isso já tinha sido super trabalhado pela coordenação, o que que eu fui fazer? Eu fui pactuar esses fluxos, Secretaria a Secretaria, porque nós pensamos em construir o Programa de baixo para cima e não de cima para baixo. $O$ Programa já era o Programa do prefeito, todo mundo já sabia, essa porta já estava aberta, mas se a gente dialogasse com os secretários, entre secretários, e eles descessem a ordem, o secretário muitas vezes não entende disso, pequenos fluxos da ponta, e nós pensamos primeiro em cativarmos essas pessoas com quem nós iríamos ter que lidar futuramente, que eram os responsáveis pelas áreas que nós identificamos como prioritária em cada Secretaria e pactuamos fluxos com essas pessoas. Então, quando os secretários foram conversar entre si, eles já tinham uma avaliação de onde estaria localizado, com quem ia tratar, que fluxo teria, o que que tinha que melhorar pra gente fazer, que era um ponto nevrálgico que a gente tinha que atuar, já com o diagnóstico completo. Então quando o secretário de Direitos Humanos, que na época era o Rogério Sottili, foi conversar com cada secretário, já tínhamos todo um diagnóstico para apresentar e aí isso facilitou muito para gente conseguir em quatro meses criar esse Programa (Larrat, 2016).

De acordo com o livro74 Transcidadania: Práticas e trajetórias de um programa transformador, lançado pela Prefeitura de São Paulo no final de 2016, após a criação da SMDHC e da Coordenadoria LGBTQIA, uma série de oficinas e rodas de conversas foram realizadas com gestores, militantes, homens e mulheres transexuais e travestis com o intuito de idealizar as diretrizes do programa. Tais reuniões deram subsídios para o coordenador na época, Alessandro Melchior, organizar a nota conceitual75 que justificou o programa frente às reuniões de parceria e articulação para a realização e execução.

\footnotetext{
${ }^{74} \mathrm{O}$ livro TRANSCIDADANIA: Práticas e trajetórias de um programa transformador foi lançado na cerimônia de formatura das turmas de 2015 e 2016, na sede da prefeitura de São Paulo no dia 22/12/2016.

${ }^{75}$ BRASIL, SÃO PAULO. Nota Conceitual do Programa TransCidadania. Secretaria Municipal de Direitos Humanos e Cidadania, dezembro de 2014.
} 
se fez muita pesquisa e a gente pediu até apoio para a ONU e não conseguimos encontrar. Encontrávamos ações de política pública, mas não um Programa que atendesse e desse conta dessa população. Então o TransCidadania, ele não se inspirou em ninguém que não fosse as necessidades das pessoas que estavam na militância, que estavam pesquisando sobre isso e que vieram conosco (Larrat, 2016).

Para Symmy Larrat a ausência de um programa modelo que pudesse guiar a equipe técnica quanto aos passos a serem tomados pelo TransCidadania em seu início, essa ausência não teve implicações necessariamente negativas. O espaço aberto para modelos de políticas públicas para pessoas trans* permitiu uma liberdade para se desenhar um programa que atendesse às aspirações e pautas dos movimentos de travestis e transexuais, das pessoas ativistas e principalmente de acordo com a realidade local vivenciada.

\subsubsection{TransCidadania: um programa Trans*.}

Pra mim é um novo olhar, um olhar que nunca ninguém teve para as travestis e transexuais. (Wanzeller, 2016)

Trata-se de um modelo de política pública de transferência de renda que permite o retorno à escola e, a partir disso, a outros espaços de socialização e, junto disso, à sociedade, por pessoas que a própria sociedade foi rejeitando, a partir da família, do mercado de trabalho e de outras instituições. (Concilio et al, 2017,p.187)

Significa um recomeço. (Nolasco, 2016)

Em virtude da comemoração do dia da visibilidade trans ${ }^{*}$, o decreto de criação do TransCidadania foi escolhido para ser lançado no dia 29 de janeiro. Nessa data, o então prefeito de São Paulo, Fernando Haddad, instituiu o programa, que, segundo o decreto, é "destinado à promoção da cidadania de travestis e transexuais em situação de vulnerabilidade social", além de alterar alguns artigos dos decretos anteriores no que se refere ao POT (Programa Operação Trabalho)76.

\footnotetext{
${ }^{76}$ Os decretos que se referem ao POT e suas alterações são os decretos municipais de $\mathrm{n}^{\circ} 44.484$, de 10 de março de 2004 e o Decreto $n^{\circ} 40.232$ de janeiro de 2001.Links: http://www3.prefeitura.sp.gov.br/cadlem/secretarias/negocios juridicos/cadlem/integra.asp?alt=11032004D\%2 0444840000 
O decreto de criação do TransCidadania, no 55.874 de 29 de janeiro de 2015, dispõe de oito artigos que determinam suas diretrizes, seu objetivo, público-alvo, serviços prestados, responsabilidades das secretarias envolvidas e as alterações nos decretos acima mencionados.

\subsubsection{Aproveitando as estruturas}

O decreto aproveita a estrutura do POT quanto à transferência de renda, e estabelece um valor77 financeiro a ser destinado as pessoas participantes do programa, desde que estes estejam em situação de vulnerabilidade social e sejam atendidos pelo CADS, mediante à uma carga horária de atividades semanais ligadas à educação, qualificação, capacitação profissional e cursos livres em direitos humanos.

As diretrizes gerais do programa são:

- I- Oferta de condições de autonomia financeira e de enfrentamento à pobreza, por meio de programas redistributivos, de elevação de escolaridade, qualificação profissional e intermediação de mão de obra;

- II - Desenvolvimento de ações de enfrentamento ao preconceito e à discriminação contra travestis e transexuais e de respeito à expressão de sua identidade de gênero e ao uso do nome social, nos termos do Decreto no 51.180 , de 14 de janeiro de $2010^{78}$;

- III - Capacitação e sensibilização permanentes dos servidores públicos municipais para a oferta de atendimento qualificado e humanizado a pessoas travestis e transexuais, observados os princípios da dignidade da pessoa humana, da igualdade e da não revitimização;

- IV - Formação cidadã em direitos humanos para o exercício da cidadania, participação popular e controle social. (Brasil, 2015)

As diretrizes do programa evidenciam os quatro pilares sobre os quais o TransCidadania iria se desenvolver: redistribuição de renda mediante a capacitação escolar e profissional, ações de enfrentamento do preconceito e discriminação contra transexuais no uso do nome social, capacitação dos servidores públicos e a formação cidadã para o exercício da cidadania.

\footnotetext{
77 Este valor é calculado com base no percentual estipulado em lei para a remuneração das pessoas participantes do programa POT e sua base de cálculo pode ser conferida no link acima.

78 Link para o decreto sobre o uso do nome social

http://www.prefeitura.sp.gov.br/cidade/secretarias/upload/chamadas/decreto_1264092483.pdf
} 
O decreto de criação do TransCidadania absorveu leis, portarias e decretos que já previam ações referentes a garantia de direitos a travestis e transexuais e garante outras ações, como por exemplo, a ampliação da rede municipal de saúde para atender a Portaria $n^{\circ} 2.803$ de 19 de novembro de 2013 do Ministério da Saúde79, que prevê o oferecimento de terapia hormonal para pessoas trans* pelo Sistema Único de Saúde (SUS).

No decreto estão previstas as responsabilidades das secretarias e parcerias envolvidas e garante a SMDHC coordenar o programa:

- acompanhar e avaliar, em articulação com as demais Secretarias Municipais, a implementação do Programa;

- encaminhar e auxiliar os beneficiários do Programa na adesão a outros programas e ações públicos e na obtenção de outros benefícios a que possam fazer jus;

- referenciar equipamentos municipais, em especial das redes de saúde, assistência social e de apoio à mulher, para atendimento e acolhimento de pessoas travestis e transexuais; 80

- prestar apoio técnico e financeiro à execução das atividades previstas no Programa. (Brasil, 2015)

Ainda de acordo com o decreto o programa TransCidadania a SMDHC passa a ter a responsabilidade de celebrar convênios e parcerias para as pessoas participantes do TransCidadania realizar as atividades ligadas ao programa:

Art. 2o Parágrafo único. A Secretaria Municipal de Direitos Humanos e Cidadania poderá celebrar convênios, parcerias ou termos de cooperação específicos para o desenvolvimento de atividades pelos beneficiários provenientes do Programa TransCidadania, respeitadas as normas e diretrizes do POT (Brasil, 2014).

\footnotetext{
79 Link de acesso a portaria sobre o tratamento hormonal nos equipamentos de saúde pública. http://bvsms.saude.gov.br/bvs/saudelegis/gm/2013/prt2803_19_11_2013.html

${ }^{80} \mathrm{O}$ Parágrafo único do referido decreto observa que: $\mathrm{O}$ referenciamento previsto no inciso III do caput deste artigo não impede nem exclui o atendimento de pessoas travestis e transexuais nos demais equipamentos públicos.
} 
O POT, principal parceiro, é um programa de responsabilidade da SMDTE. Tal programa prevê as pessoas participantes capacitação profissional para reinserção ao mercado de trabalho, auxiliando através de uma transferência de renda prevista na Lei Municipal de assistência ao trabalhador desempregado81.

O Programa Operação Trabalho, POT, é resultado da alteração da lei n 13.178/0182 criada pela então prefeita de São Paulo Marta Suplicy que, instituía Programa Ação Coletiva de Trabalho (PACT) que visava ampliar a atenção ao trabalhador desempregado. Após algumas modificações em virtude de demandas políticas, ainda sob a gestão da mesma prefeita, o PACT foi alterado pela Lei 3.689 de 19 de dezembro de 2003 passando a se chamar POT. Em 2009, já sob outra gestão, foi criada uma modalidade para atender a população LGBTQIA chamada de POT LGBTQIA.

5.2.3 Transversalidade, educação e cooperação: formação para atendimento amplo e respeitoso à pessoa *trans

Em março de 2014, sob gestão de Fernando Haddad, prevendo a criação de um programa maior que seria o TransCidadania, assinou um termo de cooperação entre a SMDHC e a SMDTE, no qual foram determinados critérios adicionais aos previstos na legislação do programa POT LGBTQIA:

Entre as ações imediatas, reduziu-se a carga horária do estágio, destinando-se um dia da semana para a realização do curso Cidadania, Direitos Humanos e Democracia e foi realizada a realocação das pessoas, pessoas participantes do programa que desenvolviam atividades em órgãos da administração estadual e em organizações da sociedade civil sem fins lucrativos para órgãos da Administração Pública municipal. (Nota Conceitual do Programa TransCidadania, 2014).

\footnotetext{
${ }^{81}$ As leis sobre transferência de renda municipal são no 13.178 de 17/09/2001 com nova redação pela Lei 13.689 de 19/12/2003. Links de acesso para a lei de transferência de renda e sua nova redação. https://cm-saopaulo.jusbrasil.com.br/legislacao/814563/lei-13178-01

http://www3.prefeitura.sp.gov.br/cadlem/secretarias/negocios juridicos/cadlem/integra.asp?alt=20122003L $\% 2$ 0136890000

82 Sobre o PACT, o programa destinava a atender o trabalhador desempregado estimulando a busca por ocupação, bem como sua reinserção no mercado de trabalho, dando assistência através de projetos em parcerias com entidades públicas ou privadas. Link para lei do programa http://www3.prefeitura.sp.gov.br/cadlem/secretarias/negocios juridicos/cadlem/integra.asp?alt=14112001D\%2 $\underline{0413850000}$
} 
Dessa forma a SMDTE, através do POT, firmou a principal parceria para implantação do programa TransCidadania, que além de permitir a transferência de renda para as pessoas participantes do programa, ajudou a definir os critérios para escolha, valor do auxílio recebido, atividades e outros regras orientadas pela lei já vigente como por exemplo:

- Ter mais de 18 anos;

- Residir na cidade de São Paulo;

- Não estar recebendo benefícios como seguro-desemprego, FGTS;

- Renda familiar de até meio salário-mínimo por pessoa da família;

- Não ter registro em carteira no último ano, em três meses consecutivos;

- Disponibilizar seis horas diárias, contabilizando trinta horas semanais;

(Brasil, 2004)

$\mathrm{Na}$ tentativa de orientar as demais pessoas da sociedade civil e servidores do município, e principalmente, garantir os direitos mínimos de bem estar a todas as pessoas transexuais que frequentem as unidades da administração municipal, direta e indiretamente, o decreto de criação do programa TransCidadania observa a obrigatoriedade de placas informativas contra a discriminação e sobre o uso do nome social, exigindo o atendimento ao decreto $n^{\circ} 51.180$ de 14 de janeiro de 20108384 .

Para além da ação inicial entre a SMDHC e a SMDTE o decreto abriu espaço para outras parcerias entre secretarias e entidades da sociedade civil. Entre as secretarias que passaram a realizar ações combinadas com o programa TransCidadania estão: Secretaria Municipal de Saúde, Secretaria Municipal de Educação, Secretaria Municipal de Políticas para Mulheres e Secretaria Municipal de Assistência e Desenvolvimento Social.

O decreto não detalha, entretanto, a responsabilidade das demais secretarias do município que viriam a se tornar parceiras do programa, porém, ele previu que a SMDHC fosse capaz de celebrar os convênios e parcerias necessárias ao atendimento transversal e multifocado.

\footnotetext{
83 Link para o decreto do respeito ao uso do nome social http://www.prefeitura.sp.gov.br/cidade/secretarias/upload/chamadas/decreto_1264092483.pdf

${ }^{84} \mathrm{E}$ nessa fase do programa que o contexto da produção de texto (Ball, 2001) acontece, produzindo os documentos políticos do programa que segundo Mainardes (2006, p.52) são o resultado de disputas e acordos. Para Shiroma et al (2005, p.434) o contexto de produção de textos é o momento que os documentos oficiais que representam a política são normalmente articulados à linguagem do público em geral.
} 
Dessa forma, coube a Coordenadoria de Política LGBTQIA solicitar a SME, através de sua Assessoria Técnica e de Planejamento (ATA) e ao Conselho Municipal de Educação (CME), a normatização e o efetivo cumprimento do disposto no Decreto Municipal $n^{\circ} 51.180$, de 14 de janeiro de 201085. Tais solicitações referem-se às providências para inserção do nome social nos registros escolares, ações de prevenção a atos discriminatórios com foco na orientação sexual e identidade de gênero e outras ações como indica o CME n² 20/1586.

Segundo o $\mathrm{CME}$, as tomadas de decisões em relação ao tratamento respeitoso às pessoas trans* está baseada no esforço internacional de debates e ações que os países e organizações têm empenhado na garantia de diretos a população de travestis e transexuais, em especial o Estado de São Paulo, que tem buscado editar suas legislações visando a garantia dos direitos e proteções de todos87.

Entretanto, as ações entre a Coordenação de Políticas LGBTQIA e a SME para a realização do TransCidadania, não se restringem às questões normativas segundo Symmy Larrat. Foram necessárias ações concretas de formação e treinamento com funcionários administrativos e docentes das escolas que receberam as pessoas participantes do programa.

Por fim, para dar a largada na implementação do programa TransCidadania e seus primeiros dias de vida ainda em 2015, foi escolhida uma entidade da sociedade civil, uma instituição chamada Koinonia Presença Ecumênica e Serviços88, que assumiu a responsabilidade pela execução de atividades educativas e monitoramento das ações do programa. Desta forma e com essas parcerias, no dia 25 de janeiro de 2015 foi dada a largada do programa, buscando com isso estabelecer um sistema de política pública transparente e transversal.

\footnotetext{
${ }^{85}$ Esta lei dispõe sobre a inclusão e uso do nome social de pessoas travestis e transexuais nos registros municipais relativos a serviços públicos prestados no âmbito das Administrações Direta e Indireta.Link para o decreto sobre uso do nome social nas escolas municipais http://www.prefeitura.sp.gov.br/cidade/secretarias/upload/chamadas/decreto 1264092483.pdf

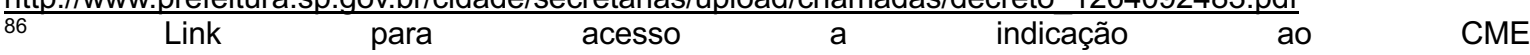
http://www.prefeitura.sp.gov.br/cidade/secretarias/upload/educacao/arquivos/Indicacao_CME 20-15.docx.

${ }^{87} \mathrm{~A}$ constituição do Estado de São Paulo (de 5 de outubro de 1989), que estabelece no inciso VII do artigo 237 a condenação a qualquer tratamento desigual por motivo de convicção filosófica, política ou religiosa, bem como a quaisquer preconceitos de classe, raça ou sexo. e na Lei $n^{\circ} 10.948 / 01$ - regulamentada pelo Decreto 55.589/10 - que trata das penalidades a serem aplicadas à prática de discriminação em razão de orientação sexual. O Decreto $n^{\circ} 55.588 / 10$ dispõe sobre o tratamento nominal das pessoas transexuais e travestis nos órgãos públicos do Estado de São Paulo. E o Decreto n 55.839/10 institui o Plano Estadual de Enfrentamento à Homofobia e Promoção da Cidadania LGBTQIA.

${ }^{88} \mathrm{O}$ Koinonia segundo o site http://koinonia.org.br/ é uma entidade ecumênica de serviço composta por pessoas de diferentes tradições religiosas, reunidas em associação civil sem fins lucrativos. Integramos o movimento ecumênico e prestamos serviços ao movimento social. Ele foi contratado pela prefeitura de são paulo para ajudar na gestão dos curso ministrados no programa e como consultoria externa.
} 


\subsection{A implementação do programa TransCidadania.}

Faltará tinta, No dia que o céu for livremente

Pra todos serem o que são

Cobertos pelo sol, sem nenhum tipo de opressão Faltará nomes, Pra descrever o mundo sem as misérias

O que sentimos, o que nos tornamos

O novo ser sem medo de viver

Faltará a falta que nos entristece

Que hoje enche o peito de vazio e fumaça

Não faltará amor, não faltará sonhos

O novo mundo se abrirá para o futuro

Onde o presente dominará o passado

E nossos corações enfim serão salvos.

(Colorir, Virginia Guitzel)

5.3.1 Desafios iniciais: critérios, recursos limitados, alcance

Dados os alicerces para a realização do programa TransCidadania, tais como as mudanças nos decretos municipais, as parcerias com as secretarias e com entidades da sociedade civil, o programa lançou-se em sua tarefa de implementação. Segundo a coordenadora, Symmy Larrat: 
Sabíamos das dificuldades e do desafio que seria implementar o TransCidadania, pois, já naquela época, vivenciávamos um cenário de avanço do conservadorismo, de ataques à pauta LGBT e sabíamos que os próximos dias seriam de resistência para manter o que já tínhamos conquistado. Então, avançar consideravelmente e construir algo que nunca ousaram fazer na gestão pública era quase impossível para muitos. Alguns, inclusive, desacreditavam que conseguiríamos. Como se não bastasse tudo isso, tínhamos a certeza que se não lográssemos êxito colocaríamos em risco toda a Política Pública para pessoas trans no Brasil (...) (Concilio et al, 2017, p.118)

No início de 2015, o TransCidadania recebeu 100 beneficiárias/os e, de acordo com dados do programa, a fila de espera para uma possível vaga chegava ao número de um mil (1000). Para superar os desafios citados na fala de Symmy e, de acordo com Nota Conceitual, foi projetada uma coordenação específica para o programa ligada à coordenação LGBTQIA, bem como à SMDC e uma equipe técnica multidisciplinar composta para atender a demanda inicial formada por: Um Coordenador/a, um Assistente de coordenação, um Assistente Administrativo, Dois pedagogos/as, Dois psicólogos/as e Dois Assistentes Sociais.

É enriquecedor a gente fazer atendimento com psicóloga e assistente
social juntos. Eu, como assistente social, vou criando uma rede do que
pode ser oferecido e a psicóloga, dentro das atribuições dela, vai
vendo o que pode oferecer. [...] é enriquecedor porque você percebe
que a questão habitacional da beneficiária está vinculada ao
sofrimento dela. A gente vê o indivíduo na integralidade e não
fragmentado [...] O indivíduo não é uma parte psicológica, uma parte
assistência e uma parte pedagógica, essas coisas vão se
entrelaçando e é atribuição dos profissionais não fragmentar (Concilio
et al, 2017, p.67). Atualmente, para acessar o programa a pessoa trans* se dirige aos Centros de Cidadania LGBTQIA localizados na cidade de São Paulo, um em cada zona (oeste, leste, sul e norte), e realizam um cadastramento. No início do programa, o cadastramento era realizado pelo antigo CADS (Coordenadoria de Assuntos de Diversidade Sexual). 
Os centros de Cidadania LGBTQIA funcionam tanto no eixo de defesa dos Direitos Humanos das pessoas LGBTQIA, às acolhendo no apoio psicológico, jurídico e social, como recebendo e encaminhando as vítimas de violência; atuam, também, no eixo de promoção de Cidadania LGBTQIA, realizando capacitação de servidores municipais quanto ao atendimento a pessoas LGBTQIA.

Ao chegar ao Centro de Cidadania LGBTQIA, a pessoa travesti ou transexual passa por um processo de acolhimento e levantamento de informações, com o objetivo de determinar se ela se enquadra nos critérios estabelecidos pelo programa para adesão. Se a pessoa que está tentando uma vaga no programa se enquadrar, ela entra em uma fila de espera e, caso seja selecionada, é atendida novamente pelas assistentes sociais89 do programa.

De acordo com Symmy, muitas mulheres travestis e transexuais procuraram o programa mesmo possuindo diplomas de ensino médio e, algumas vezes, de ensino superior. Na visão dela, isso se dá porque toda mulher transexual, travesti e homens trans está em situação de vulnerabilidade, em maior ou em menor grau. O mercado de trabalho é transfóbico, tendo você um diploma ou não, o que dificulta o acesso de pessoas trans a posto de trabalho, mesmo que atendam às exigências de escolaridade. Um dos casos é o de Milena Wanzeller: "Quando eu soube que a prefeitura ia lançar o programa, eu procurei o programa com a intenção de ser beneficiária... mas eu não me encaixava... e a Symmy me propôs a ideia de trabalhar" (Wanzeller, 2016).

Os critérios atribuídos para participar do programa de acordo com o decreto de criação eram:

${ }^{89} \mathrm{O}$ programa destaca que esse novo atendimento com a beneficiária selecionada é necessário para o início de criação de vínculo e informar seus direitos e deveres quanto ao programa. 
- Ser mulher transexual ou mulher travesti ou homem trans;

- Ter ensino médio ou fundamental incompleto;

- Disponibilizar uma carga horária de no mínimo $2 \mathrm{~h}: 15$ min à $4 \mathrm{~h}$ diárias de acordo com a escolaridade; além de compor as demais horas com outras atividades do Programa, totalizando às 6 horas diárias;

- Participar do curso de Direitos Humanos;

- Participar de cursos profissionalizantes;

- Participar de cursos preparatórios para o mercado de trabalho;

- Ser atendido(a) individualmente;

- Participar de grupos psicossociais;

- Envolver-se na participação popular e controle social;

- Realizar estágio. (Brasil, 2015)

Com direitos e deveres explícitos para as beneficiárias, a assinatura do termo de compromisso é realizada. A partir daí as pedagogas do programa explicam sobre a escola de referência, matrícula, acompanhamento e provas de nivelamento e então, elas são encaminhadas pelo setor administrativo do TransCidadania à SMDTE, para a assinatura do termo de compromisso do POT, que tem vigência de 2 anos de acordo com as regras do órgão.

O termo de compromisso do programa TransCidadania é composto por sete cláusulas que tentam nortear as diretrizes quanto a participação no programa. As cláusulas abordam o surgimento do programa, seu decreto, sua definição e seus objetivos, entre eles, a oferta de condições de autonomia financeira, desenvolvimento de ações de enfrentamento ao preconceito e à discriminação contra travestis e transexuais, capacitação e sensibilização permanente dos servidores públicos e formação cidadã em Direitos Humanos. A cláusula primeira enfatiza as ações que o programa iria desenvolver, mas inclui outras que poderão ser definidas pela coordenação do programa ao longo do processo. Tais ações são: 
- Qualificação dos beneficiários por órgãos municipais ou entidades conveniadas por meio do POT;

- Inclusão em cursos de Educação de Jovens e Adultos (EJA) e Centros Integrados do EJA, em modalidade regular;

- Cursos de qualificação, por meio do PRONATEC;

- Inscrição das beneficiárias em edições anuais do Exame Nacional de Ensino Médio (ENEM);

- Inscrição e encaminhamento das pessoas participantes para os Centros de Apoio ao Trabalhador (CAT) e outras intermediações públicas e privadas de mão de obra;

- Encaminhamento para atendimento sócio-Assistencial no Centro de Referência e Assistência Social e nos especializados para população em situação de rua;

- Encaminhamento dos beneficiários em situação de rua para as vagas no Centro de Acolhida.

- Oferta de terapia hormonal, no âmbito do processo transexualizador e pelo Sistema Único de Saúde, em unidades referenciadas pela Secretaria Municipal de Saúde.

- Referenciamento e treinamento das equipes da UBS, CAPS, CAPS AD, CTA e SAE para a garantia de atenção à saúde integral a população $T$.

- Orientações sobre os critérios de priorização e acesso a programas habitacionais do município;

- Curso e ações de promoções da consciência cidadã;

- Campanhas anuais sobre o respeito ao direito quanto ao uso do nome social nos órgãos públicos municipais;

- Encaminhamentos de mulheres Travestis e Transexuais vítimas de violência doméstica para o Centro de referência da Mulher;

- Auxílio financeiro para cada participante do programa como prevê o POT.

O termo de compromisso aborda, na cláusula segunda, questões quanto às condições para de acesso ao programa, tais como algumas das exigências do POT, principalmente em relação à renda mínima. $O$ termo aborda também os direitos e deveres das pessoas participantes, questões referentes ao desligamento e tempo máximo de permanência no programa, e a responsabilidade sobre disposições gerais. Um importante ponto a ser do termo refere-se ao caso de a participante possuir outras fontes de renda. Sendo a cláusula quarta do termo, somente é vedada ao beneficiário a participação em outros programas e atividade salubres em órgãos ou entidades do município. A ênfase neste ponto é para salientar uma questão que surgiu ao longo do trabalho sobre o auxílio ser suficiente para manutenção de vida das pessoas participantes, e se havia a obrigação de não exercer atividades anteriores ao projeto, como é o caso das profissionais do sexo. 
Paralelamente à análise das condições de acesso, a pessoa participante, junto aos técnicos de referência, inicia o processo de formulação do Plano Individual de Atendimento90 (PIA), bem como são iniciados nas demais atividades do programa. Com isso, cada pessoa participante do programa tem como equipe de acompanhamento próxima uma assistente social, uma psicóloga e uma pedagoga, com funções distintas, mas que se complementam no processo de acompanhamento multidisciplinar.

Essa postura colaborativa e multidisciplinar foi estendida para as práticas que 0 TransCidadania realizava com o público externo. Cobrando de secretarias de administração municipal, ações que pudessem contribuir com o desenvolvimento do programa e acionando ferramentas que, por lei ou decreto, já estavam garantidas, mas que, na prática, tinham pouca efetividade.

Por isto, a intersetorialidade visava combater esses lapsos da administração pública, tentando, através da sensibilização, promover maior efetividade em ferramentas já estabelecidas. Essas ações foram postas em prática com as Secretarias de Assistência Social, de Educação, de Trabalho, de Assistência e Desenvolvimento Social, de Saúde, de Políticas para Mulheres.

De acordo com o relato de Cíntia Spindola, assistente social:

"o processo de sensibilização da rede intersetorial está para além do acompanhamento individual da (o) beneficiária (o) [...] esse processo se constitui na articulação da rede, como um trabalho que subsidia a ampliação do acesso dos usuários aos diversos serviços intersetoriais" (Concilio et al, 2017, p.49).

Para Larrat (2016):

O programa é intersetorial, portanto trabalho no sentido de fortalecer os serviços públicos para o atendimento e acolhimento da população T. Nosso objetivo era fazer com que a rede funcionasse para o atendimento de mulheres travestis e transsexuais e especializar a rede municipal para isso também.

${ }^{90}$ Documento em Anexo. 
Ao Centro de Cidadania LGBTQIA, por exemplo, foi delegada a função de canalizar a sensibilização dessa rede que envolveu outros órgãos como o CRAS, Centros de Acolhida, Centro Integrado de Educação de Jovens e Adultos (CIEJA), Centro de Atenção Psicossocial (CAPS), Sistematização da Assistência de Enfermagem (SAE), Conselho Regional de Terapia (CRT) e Conselho Regional de medicina (CRM), possibilitando o desenvolvimento da transversalidade 91 entre os setores, característica da fundação da SMDHC à qual o TransCidadania está ligado.

Tanto a multidisciplinaridade, quanto o sistema de cadastramento e seleção das pessoas participantes, foram alterados no decorrer do programa. A multidisciplinariedade92 e o inter setorialismo93 foram conceitos bastante utilizados pelos gestores do programa, e suas ações buscavam refletir este direcionamento. lidar com a diversidade disciplinar no dia a dia mostrou-se um desafio, principalmente ao que tange à tomada de decisões.

De acordo com o levantamento dos dados, no início do programa não eram previstas reuniões regulares das equipes. O cadastramento, inicialmente, se daria por ordem de chegada. Algumas mudanças foram apontadas como necessárias de acordo com a percepção da equipe sobre o programa.

A gente construía, fazia de uma forma, se reunia, não deu certo, vamos mudar, agora vai ser desse jeito, a gente veio construindo isso (Wanzeller, 2016).

\footnotetext{
${ }^{91} \mathrm{~A}$ transversalidade de acordo com de Menezes e dos Santos (2001) diz respeito à compreensão dos diferentes objetos de conhecimento.

${ }^{92} \mathrm{De}$ acordo com Bibeau (1996) a multidisciplinariedade é conjunto de disciplinas que simultaneamente tratam de uma dada questão, problema ou assunto, sem que os profissionais implicados estabeleçam entre si efetivas relações no campo técnico ou científico; é um sistema que funciona através da justaposição de disciplinas em um único nível, estando ausente uma cooperação sistemática entre os diversos campos disciplinares;

${ }^{93}$ Segundo o Plano Decenal (2011) a intersetorialidade é uma lógica de gestão que transcende um único setor da política social e estratégia política de articulação entre setores sociais diversos e especializados. http://matriz.sipia.gov.br/conceitos/233-conceito-intersetorialidade
} 


\title{
5.4. Retratos do cotidiano do programa TransCidadania.
}

\begin{abstract}
O PIA vai te dando ferramentas para conhecer aquela pessoa, dali você vai saber da onde a pessoa veio, quantos anos ela tem, ela é natural da onde, como ela saiu da escola, se ela faz acompanhamento de saúde, se não faz... Se ela já fez exame de DST, se ela não fez... Se ela já fez algum curso... O que ela gosta de fazer, se ela tem família, amigos... Assim, a gente tem um panorama da vida daquela pessoa, e aí você consegue pensar junto com ela e o que podemos fazer juntos (Concilio et al, 2017, p.59).
\end{abstract}

\subsubsection{Quem são os atendidos nos programas?}

De acordo com o balanço oficial do programa TransCidadania, obtido através da Prefeitura de São Paulo no final de 201694, durante os dois primeiros anos de vida do programa passaram pelo mesmo 221 pessoas travestis e transexuais, sendo 194 pessoas que participaram ativamente e concluíram etapas do programa (83 beneficiárias da turma que iniciou em 2015 e 111 beneficiárias da turma de 2016), e 27 pessoas que foram desligadas em 2016 (17 beneficiárias da turma de 2015 e 10 beneficiárias da turma de 2016).

As características gerais da maioria das pessoas participantes seguem o padrão de exclusão social das populações trans* em nossa sociedade. A maioria das pessoas participantes são mulheres trans e travestis entre 30 a 49 anos de idade $(61,5 \%)$, pretas e pardas $(64,7 \%)$, vindas da região sudeste $(43 \%)$ e nordeste do país $(42,1 \%)$. Segundo o balanço do Programa TransCidadania de 2015-2016, o programa atendeu pessoas de idade em média entre 18 a 60 anos, sendo a maioria entre 30 a 49 anos. De acordo com o próprio balanço, o número de pessoas participantes acima de 60 anos é igual a 2. Esses dados refletem o que Antunes (2013, p.140) já apontava em seu trabalho "Travestis envelhecem?", em que expõe o triste fato de que a expectativa de vida de uma pessoa trans ou travesti é de, em média de 35 anos de idade, metade da expectativa de vida de uma pessoa cisgênera, que segundo o IBGE95 é de 75 anos.

\footnotetext{
${ }^{94}$ Balanço dos anos de 2015 e 2016, dois anos do programa TransCidadania na gestão do prefeito Fernando Haddad em Anexo.

${ }^{95}$ IBGE é o Instituto de Brasileiro de Geografia e Estatística, que é o principal provedor de dados e informações no País. http://teen.ibge.gov.br/noticias-teen/7827-expectativa-de-vida
} 
Figura 1 Relação por região de nascimento das pessoas participantes do TransCidadania.

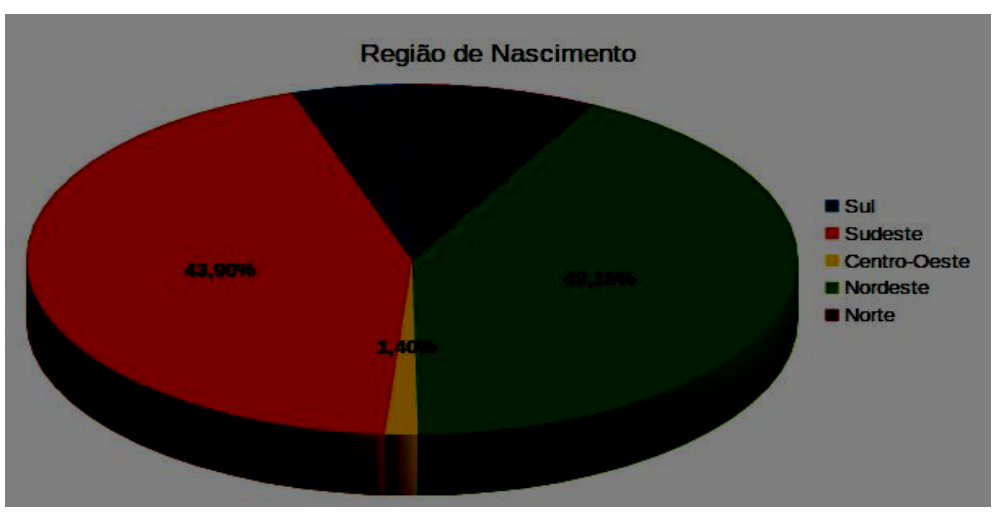

Fonte: Balanço 2015 - 2016 do Programa TransCidadania. Prefeitura de São Paulo.

O gráfico visto na Figura 1 retrata a divisão por região de nascimento das pessoas participantes inscritas no programa. Considerando o histórico de construção social da cidade de São Paulo esses números não apresentam surpresas, mas um processo de mobilidade urbana marcado pela migração e pelo Êxodo Rural, que constituiu e constitui a cidade. São Paulo é a capital do Brasil que mais recebe pessoas vindas de outras regiões do país em busca de novas oportunidades em uma cidade de configurações metropolitanas. E, embora existam no país outros polos de atração de mão de obra, a capital paulista continua sendo a região que capta a maioria dos diversos migrantes e imigrantes de outros países.

Deste modo, em relação às demais regiões, além da própria onde está localizado o programa TransCidadania (Sudeste), percebe-se uma grande quantidade de pessoas participantes vinda da região nordeste $(42,1 \%)$, seguida da região norte $(7,7 \%)$, sul $(5 \%)$ e centro-oeste $(1,4 \%)$ do país. Ainda de acordo com os dados do balanço, a maioria das pessoas participantes são oriundas da região sudeste e do próprio estado de São Paulo (84,5\%), seguidas de Minas Gerais (11,3\%) e Rio de Janeiro $(4,1 \%) 96$.

\footnotetext{
${ }^{96}$ Importante frisar que esses dados se referem as pessoas participantes do TransCidadania, e não tenta, de maneira alguma, determinar a composição regional da totalidade de travestis e transexuais da cidade de São Paulo.
} 
Quanto a diversidade racial entre as pessoas participantes do programa TransCidadania, percebe-se que as autodeclarações se concentram entre brancas, pretas e pardas. Onde a população de pretas e pardas juntas, como o IBGE sugere, é superior à população de brancas, $64,7 \%$ e 35,3\% respectivamente. Esses dados confirmam a configuração étnica e social brasileira, uma vez que, além da população preta e parda ser maioria na composição da população brasileira, esses números aumentam ao considerarmos as populações de maior vulnerabilidade social.

Esses dados foram coletados a partir do PIA, que é utilizado pela Assistente Social como um primeiro contato direto com a pessoa participante do programa. A partir do PIA, ela pode observar características, colher relatos e expectativas de futuro. $O$ documento é importante para traçar a linha do tempo da beneficiária dentro do programa, e o início do seu processo de cuidado individual. Apesar de ser um documento padrão, foi adaptado para o contexto do programa, para atender especificamente a população trans*.

O PIA foi constituído de maneira que englobasse as áreas que norteiam o programa, como serviço social, psicológico e pedagógico, como: identificação e documentação, escolaridade e aspectos pedagógicos, atividade laborativa e profissionalização, cultura, lazer, esporte, religião, situação habitacional, composição familiar e levantamento socioeconômico, saúde, percurso de transição, relacionamentos interpessoais, jurídicos e qualidade de vida. É utilizado também como referência no atendimento individual realizado psicológico e com a assistente social.

\subsubsection{Quais os tipos de Atendimento do Programa?}

Os atendimentos das pessoas participantes do programa TransCidadania ocorrem em três formatos: grupos psicossociais, atendimento individual e atendimento espontâneos/emergenciais. Os atendimentos em grupos psicossociais são atividades coletivas, coordenadas por uma assistente social e uma psicóloga. Ocorrem a cada 15 dias, de acordo com temas propostos pela coordenação e pelas beneficiárias, através de ações musicais, com filmes, e textos que auxiliem na discussão do tema escolhido. De acordo com Aparecida (2017), é necessário para a aproximação da equipe com as beneficiárias, e, também, para trabalhar questões de cidadania e coletividade entre as pessoas participantes. 
É um espaço de encontro em que se possa falar, ouvir o outro e a si próprio. É um espaço em que se pode construir esse movimento de vínculo e, nessa construção, ter um espaço de apoio, de fortalecimento coletivo e troca (Concilio et al., 2016).

Existem também os atendimentos espontâneos/emergenciais que ocorrem com uma frequência alta, semelhante aos demais órgãos de atendimento a pessoas LGBTQIA, como é o caso do centro de referência de Cidadania LGBTQIA. De acordo com a então coordenadora Symmy Larrat, as pessoas participantes do programa e outras pessoas travestis e transexuais criam uma relação com o espaço, o enxergando como um lugar onde serão acolhidas. O que para a Symmy, ressalta ainda mais a necessidade de espaços de acolhimento para essa população, ainda bastante raros na esfera pública (Concilio et al, 2017, p.66).

Ainda de acordo com os dados, as pessoas trans* que não conseguem vaga no programa TransCidadania são encaminhadas para atendimento pelo centro de referência LGBTQIA, onde recebem apoio psicológico, jurídico e orientações quanto a seus direitos nos serviços de saúde. A seguir, apresento um resumo gráfico quanto ao fluxo de entradas das pessoas participantes no programa TransCidadania.

Figura 2 - Fluxograma do funcionamento da entrada das pessoas participantes no TransCidadania.

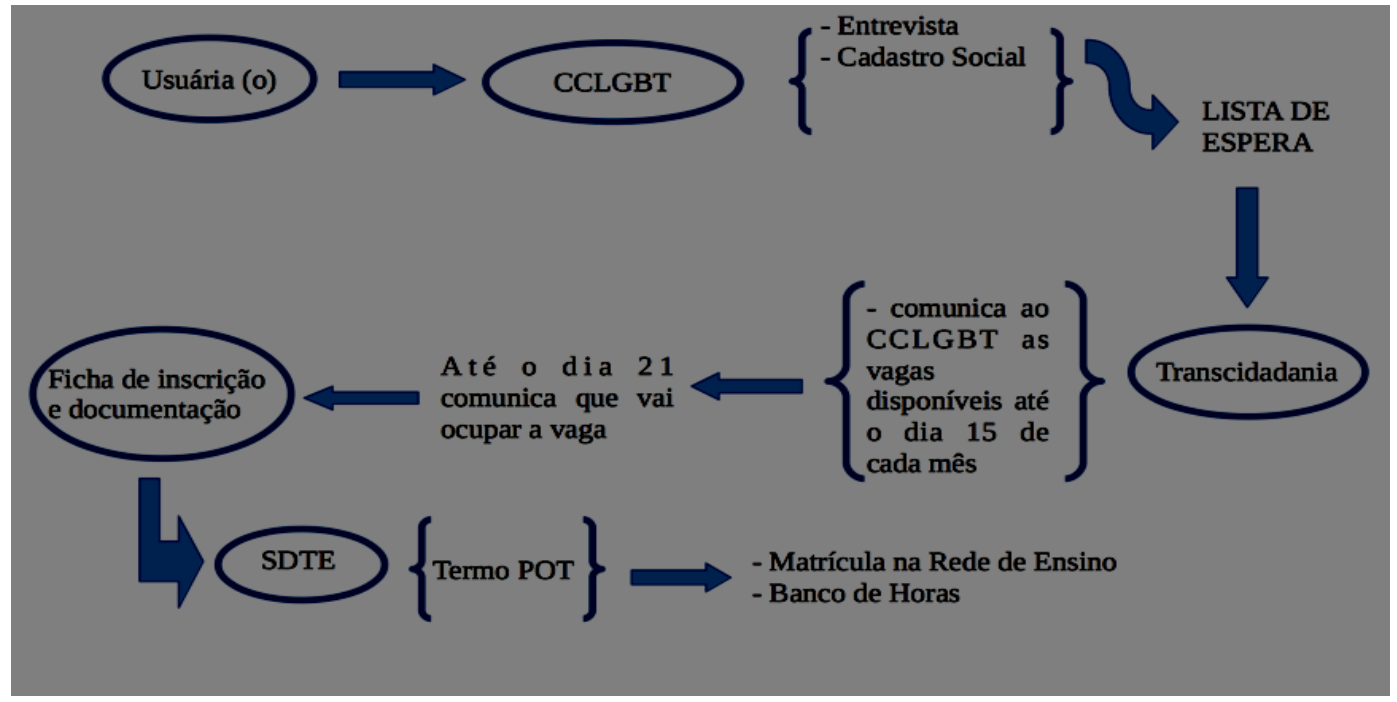

Fonte: São Paulo (Município). Secretaria de Direitos Humanos e Cidadania. TransCidadania: Práticas e Trajetórias de um Programa Transformador. Dez. 2016. São Paulo. SP. Feito pela autora. 
Iniciado o atendimento, as atividades pedagógicas também têm início, tanto na escola, quanto no centro do programa com as oficinas e cursos. De acordo com a nota conceitual do programa, o calendário geral de atividades pedagógicas prevista é dividido em quatro módulos semestrais, onde o primeiro módulo é composto por aulas do EJA (Educação de Jovens e Adultos), curso de cidadania, direitos humanos e cidadania. No segundo e terceiro módulo, além das aulas do EJA - que seguem até o final do quarto módulo - são acrescentados cursos do PRONATEC e de qualificação profissional, sendo que o quarto módulo é dedicado à realização de estágio.

Ao ser inserido no programa, a participante pode escolher, dentre as escolas parceiras, a que melhor atende suas necessidades. Entre as escolas parceiras do programa estão: CIEJA Cambuci, Emef, Celso Leite, CIEJA Butantã, CIEJA Campo Limpo e Ermelino Matarazzo. Até 2015, as escolas parceiras ofereciam o Ensino Fundamental, porém, a partir deste do ano de 2016, com a formação das pessoas participantes e o preenchimento de vagas remanescentes, surgiu a demanda para o Ensino Médio, quando foi firmada uma parceria com o Núcleo de Inclusão Educacional do Estado, onde foram selecionadas as escolas E.E. Professor Roldão Lopes de Barros, E.E. Caetano Campos e a E.E. Rodrigues Alves.

De acordo com Symmy Larrat o programa buscou não determinar de maneira unilateral qual escola as pessoas participantes do programa seriam matriculadas, antes, levou em consideração a opinião das mesmas sobre sua preferência de localização, levando em consideração fatores como a região que residiam.

As escolas que receberam as pessoas participantes foram beneficiadas com cursos de capacitação em direitos humanos, direitos civis e abordagem sobre vida cotidiana das travestis e transexuais, dando ferramentas e condições para que pudessem acolher as pessoas participantes, evitando, dentro do possível, um ambiente de estranheza e hostilidade.

Ao serem selecionadas para parceria, são realizadas uma série de oficinas e rodas de conversa, visando a capacitação dos professores, coordenadores, diretores e demais funcionários, sobre os temas: sexualidade, gênero e os direitos já previstos em lei como o nome social, por exemplo, e outras dúvidas que surgem por parte da escola para como receber a população Trans*. Tudo isso para tentar proporcionar ao máximo um ambiente acolhedor para as beneficiárias do programa e para que as mesmas se sintam confortáveis em procurar os responsáveis caso ocorra alguma situação desagradável de violência ou preconceito. 
A pedagogia está nessas escolas não só para compreender as demandas voltadas ao processo de aprendizado, mas, sobretudo, na construção e intervenção dos currículos escolares, em que nunca se viu tantas pessoas trans. A pedagogia tocou na cultura escolar, construiu outra cultura em que não se permitia a violação de direitos, como uso do nome social e acesso ao banheiro de acordo com o gênero de identificação. Construir uma nova cultura escolar é tocar na base de muita gente, inclusive de professores e gestores (Concilio et al, 2017, p.92).

A equipe pedagógica tem como parte de suas atribuições, o acompanhamento do desenvolvimento escolar das pessoas participantes, acompanhamento das instituições escolares e a promoção das oficinas que ocorrem neste ambiente, para além de coordenar o banco de horas das beneficiárias. Esse banco de horas, referese à carga horária que cada beneficiária deve cumprir de acordo com os termos do POT, cabendo a equipe pedagógica o oferecimento de atividades complementares. Além de acompanhar os serviços de pedido de passe livre para as estudantes, conforme descrito no fluxograma de educação:

Figura 3 - Fluxograma das atividades escolares e acompanhamento pedagógicos.

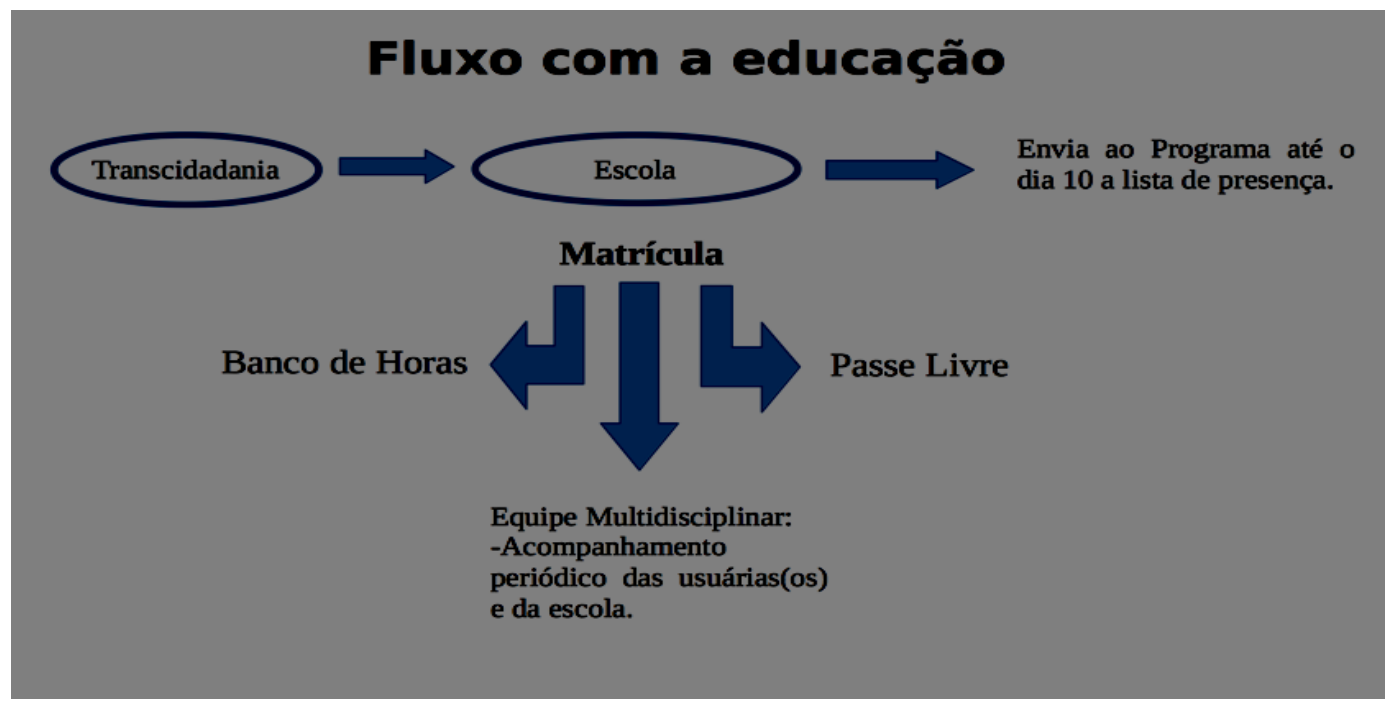

Fonte: São Paulo (Município). Secretaria de Direitos Humanos e Cidadania. TransCidadania: Práticas e Trajetórias de um Programa Transformador. Dez. 2016. São Paulo. 
Quando o programa iniciou, em janeiro de 2015 , cerca de $64,2 \%$ das pessoas participantes do programa havia abandonado a escola no ensino fundamental II, ou seja, de $5^{\text {a }}$ a $8^{\text {a }}$ série (ou $6^{\circ}$ ao $9^{\circ}$ ano). Quando se compara os dados em relação a idade que as beneficiárias evadiram a escola, 36,1\% tinham entre 13 e 15 anos, 32,5\%, 16 e 18 anos. Comparando esses dados, pode-se inferir que é relevante quando pesquisadores como Bento (2011, p. 558) afirmam que a maioria das travestis e transexuais saem da escola no período da adolescência e juventude, quando estão passando pelo período inicial de transição e assumindo sua identidade de gênero ou sexualidade perante a sociedade, sendo a escola um dos principais espaços de exclusão.

Os gráficos abaixo demonstram com mais detalhes como estava a vida escolar das beneficiárias quando entraram em contato com o programa: 
Figura 4 - Balanço da série que as pessoas participantes pararam os estudos antes de ingressarem no programa.

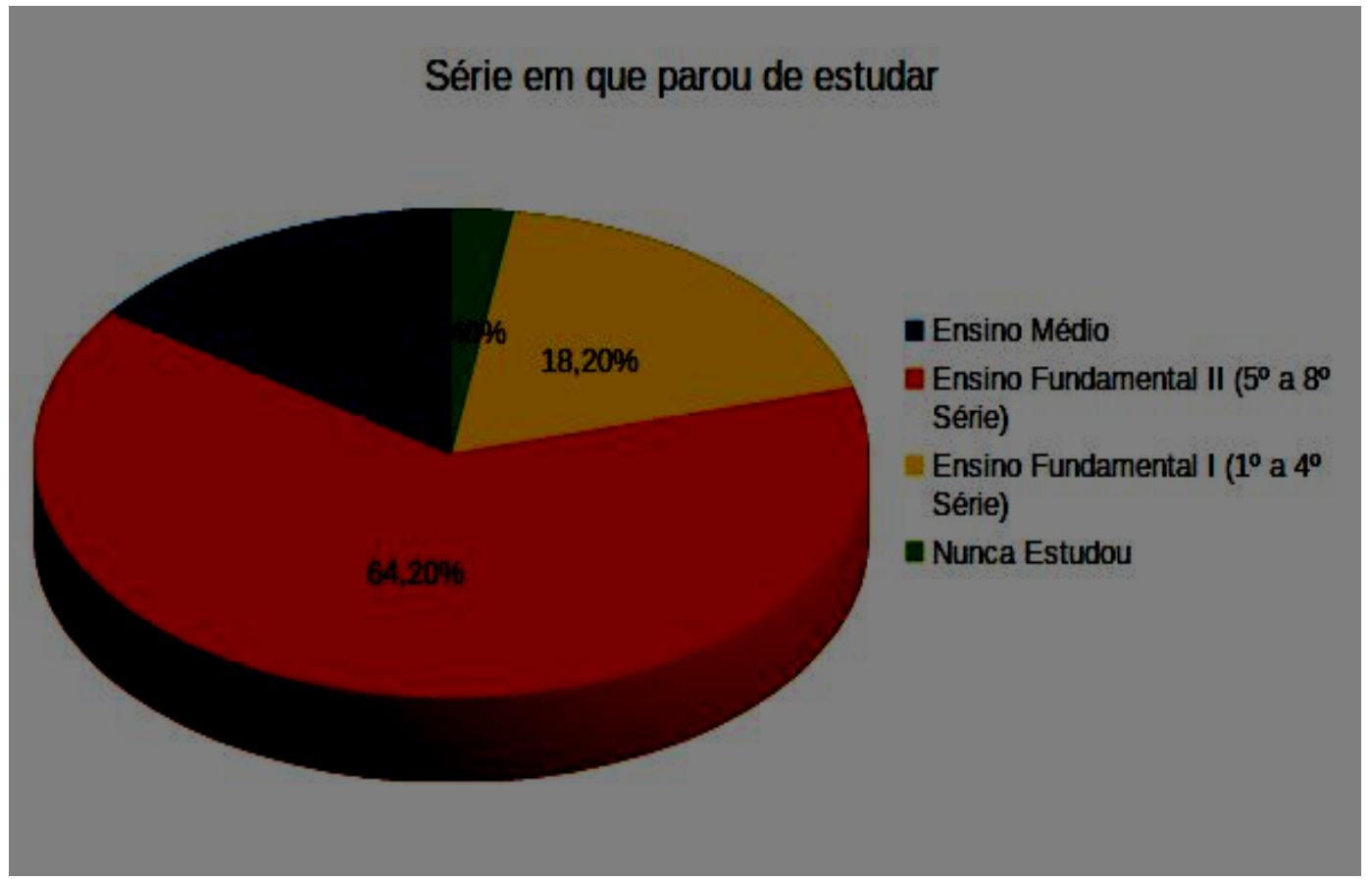

Fonte: Balanço 2015 - 2016 do Programa TransCidadania. Prefeitura de São Paulo.

Figura 5 Balanço entre evasão escolar e idade das pessoas participantes antes de ingressarem no programa.

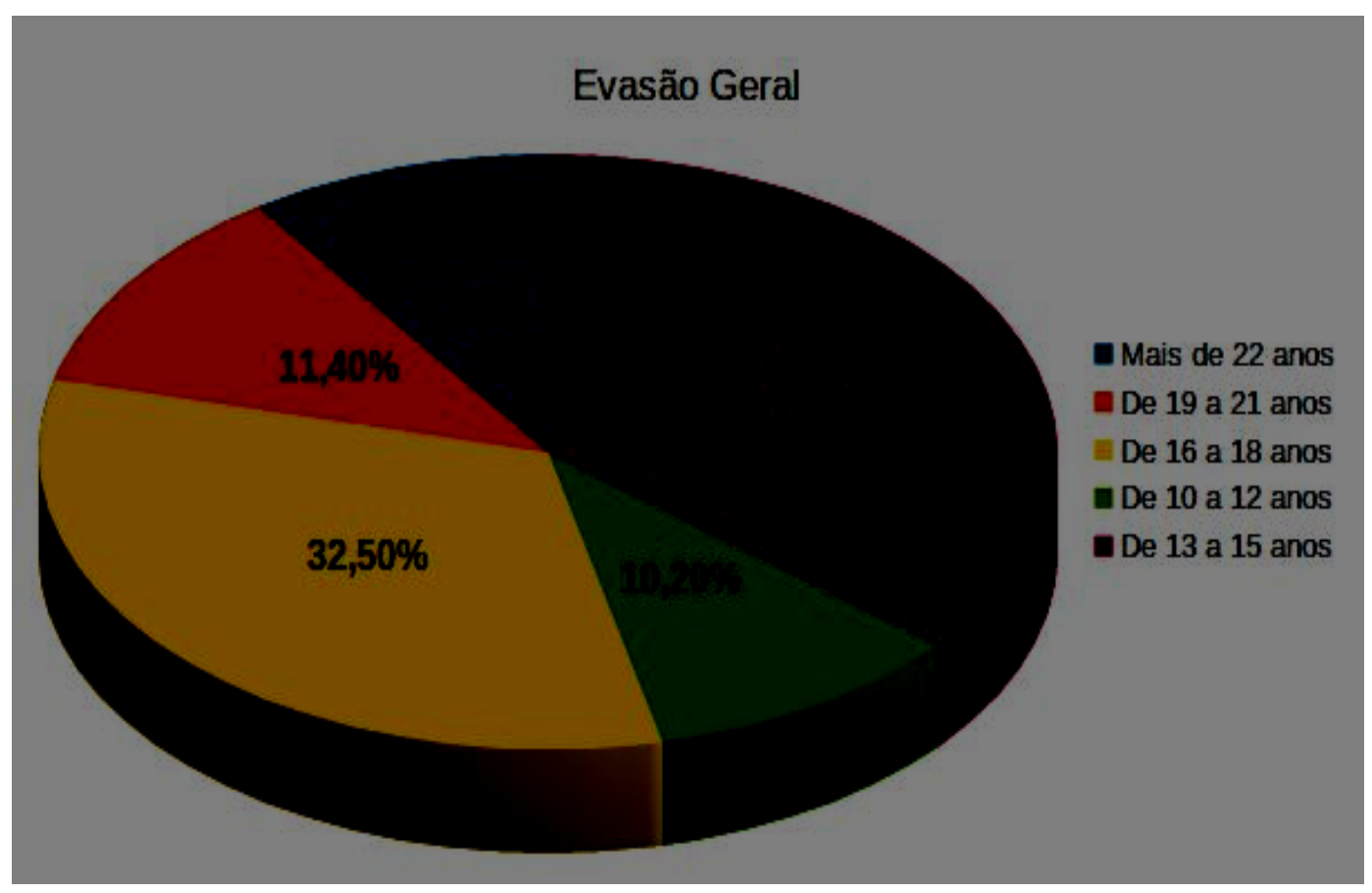

Fonte: Balanço 2015 - 2016 do Programa TransCidadania. Prefeitura de São Paulo. 


\subsubsection{Educação para a cidadania}

Paralelamente ao ensino básico, é oferecido, na sede do programa, o curso de Direitos Humanos, ministrado por membros da organização civil Koinonia. Este curso é previsto pela programação oficial do TransCidadania, e é de suma importância, uma vez que, nas palavras de Bento (2014, p.176) "a população trans vive hoje uma cidadania precária, uma dupla negação: nega a condição humana e de cidadão/cidadã de sujeitos que carregam no corpo determinadas marcas" e necessita saber mais sobre o que a legislação do país diz sobre seus direitos como cidadãos.

Para Alexandre Pupo e Ester Lisboa, membros da Koinonia, era fundamental diferenciar o espaço de formação em Direitos Humanos do espaço convencional da sala de aula para que fosse possível criar um ambiente mais acolhedor e que proporcionasse uma maior interação entre as pessoas participantes que, segundo eles, puderam diminuir a rivalidade entre elas:

No processo de se reconhecerem enquanto iguais e companheiras, elas conseguiram se organizar para propor e solicitar coletivamente 0 preenchimento de demandas tanto ao Programa quanto ao poder público (Concilio et al, 2017, p.100).

Para realização do curso, a Koinonia também contou com auxílio de parceiros, entre eles o Grupo de Estudos de Direitos e Sexualidade, da Faculdade de Direito da USP (GEDS), que se responsabilizou em abordar temas como Gênero, corpo e direitos sociais, participação social, entre outros. Os módulos que o curso de Direitos Humanos engloba são: 1 - Apresentação e introdução aos temas de Direitos Humanos; 2 - Concepção de estado, política e cidadania; 3 - Gênero, estado, corpo e direitos sociais; 4 - Direito, Constituição, Participação e movimentos sociais.

A Koinonia contribuiu, também, firmando novas parcerias, ampliando, assim, as atividades oferecidas pelo programa. São elas: oficinas de dança, teatro e expressão corporal, em parceria com o Centro de Dança de São Paulo. Cursos de preparação para o Exame Nacional do Ensino Médio (ENEM) em parceria com a UNEAFRO97. Oficinas de desenho, fotografia, elaboração de textos, pelo Grupo Lampeoa.

\footnotetext{
${ }^{97}$ De acordo com o site http://uneafrobrasil.org/ a UNEAFRO é União de Núcleos de Educação Popular para Negras/os e Classe Trabalhadora agrega militantes da causa negra.
} 
Porém, apesar da forte ênfase do programa na questão da educação como forma de efetivação da cidadania e geração de oportunidades, a atuação do mesmo não se limitou a isto. De acordo com Paola Sousa, o programa buscou:

Fazer esses alunos e alunas se sentirem bem na escola ultrapassa tornar a escola um ambiente confortável e acolhedor, pois fora da escola, na vida privada, existem demandas mal resolvidas e atravessadas: de saúde e habitação entre outras (Concilio et al, 2017, p.92).

Já o serviço social do programa busca abarcar os serviços de referência e contra referência, na orientação quanto aos direitos das pessoas trans* ${ }^{*}$ na articulação de vagas em centros de acolhidas para as pessoas trans* em situação de rua e no cadastramento do Centro de Referência da Assistência Social no CAD único98.

De acordo com a então coordenadora Symmy Larrat, esse atendimento foi fundamental em dois sentidos: no de atuar contribuindo com a situação precária das pessoas participantes, e, também, no debate sobre centros de acolhidas especificamente para pessoas trans*, que atendessem não apenas as beneficiárias do TransCidadania, mas outras pessoas trans* em situação de rua.

Para Symmy o programa contribui na articulação da Casa Florescer99, inaugurada em 2015, que inicialmente recebeu com prioridade as pessoas participantes do TransCidadania, estendendo às demais pessoas trans* do município.

Hoje, nós temos uma casa de acolhimento específica para mulheres trans, que foi uma demanda que nós apontamos na rede e ela existe, ela existe porque o TransCidadania existiu (Larrat, 2016).

5.4.4 Acesso a direitos básicos: moradia, saúde e identidade

\footnotetext{
${ }^{98}$ De acordo com o site do Governo Federal o CADúnico é O Cadastro Único para Programas Sociais (CadÚnico) é um instrumento de coleta de dados e informações com o objetivo de identificar todas as famílias de baixa renda existentes no País. http://www.brasil.gov.br/economia-e-emprego/2010/03/cadunico

${ }^{99} \mathrm{De}$ acordo com o site http://www.guiagaysaopaulo.com.br/1/est--centro-de-acolhida-para-mulheres-travestise-transexuais-florescer--943.htm A casa florescer é o primeiro centro de acolhida para mulheres transexual e travestis em São Paulo.
} 
Quanto a situação das beneficiárias ao entrarem no programa $28,5 \%$ das pessoas participantes viviam em situação de rua, desabrigadas, casas cedidas, ocupadas ou albergues, de acordo com o balanço oficial de 2016. A maioria vivia em casas alugadas $(60,2 \%)$ e apenas $11,3 \%$ possuíam casas próprias. Esses dados podem ser acessados através do cadastro das pessoas participantes e são acompanhados pela equipe psicossocial do programa.

A equipe psicológica por exemplo, dentro do programa, cumpre a função de manter as relações entre as beneficiárias do programa e os serviços de referência e contra referência, mas também cumpre um importante papel no auxílio dos pareceres psicológicos para os processos de retificação de registro civil, acompanhamento nas UBS e a realização da hormonioterapia.

Porém para a psicóloga Clair, o espaço de acompanhamento dentro do programa não é suficiente e compatível com sessões psicoterapêuticas, e muitas das pessoas participantes já realizam esse tratamento com outras profissionais, cabendo à equipe focar nas atividades de grupo, no acompanhamento das ações que as pessoas participantes executam através do programa, acompanhamento do processo psicoterapêutico com os outros profissionais e no que mais for possível dentro do programa.

Aqui não é um lugar pra se fazer psicoterapia, em contrapartida, eu acredito fielmente, que cada encontro que nós fazemos têm sim um potencial terapêutico. Isso independe (Aparecida, 2016).

Dos processos que a equipe de psicologia acompanha, podemos destacar a contribuição no processo de retificação do registro civil. Entende-se que a retificação do nome no registro civil serve como mecanismo de acesso à cidadania para transexuais e travestis, pois, conforme exposto no capítulo anterior sobre os tratados e convenções internacionais, os direitos da personalidade são essenciais para a efetivação da Dignidade Humana e, entre tais direitos, o direito ao nome é destacado no acesso à cidadania. Porém esse direito é negado às pessoas travestis e transexuais, uma vez que seu nome atribuído não representa sua identidade. 
Até o momento do primeiro ciclo do programa TransCidadania 2015 - 2016, a jurisprudência e doutrina têm possibilitado a retificação do registro civil nome e sexo, principalmente, mas não apenas, quando a pessoa trans* realiza a cirurgia de redesignação sexual. Entretanto, ainda se utilizando dos pareceres psicológicos que tratam a transexualidade e travestilidade como doenças, atribuindo a elas um CID100. Em maio de 2018 através de uma ação, o STF decidiu aprovou a mudança de nome de acordo com o gênero que as pessoas se identificam nos cartórios do país, independente de comprovação médica sobre cirurgias de designação de genitália. Apesar de o Brasil ainda não ter uma legislação específica que trate sobre o tema, na prática a ação do STF põem fim a um capítulo de uma luta das pessoas trans* que recorriam ao judiciário para obter um direito, mediante a comprovações médicas e psicológicas, e ainda dependiam do bom senso do julgador.

É no sentido de criar um parecer psicológico que vá no sentido oposto ao de patologizar a pessoa transexual e travesti que giram os esforços da equipe do TransCidadania. De acordo com José Luiz Gomes, psicólogo, "o programa TransCidadania tem entre suas ações, o Projeto de Retificação de Registro Civil (PRRC)" que se iniciou em meados de 2015 com contribuições do Núcleo de Especializado de Combate à Discriminação, Racismo e Preconceito da Defensoria Pública do Estado de São Paulo, Conselho Regional de Psicologia de São Paulo, consultas ao site do Conselho Federal de Psicologia (CEP), as experiências dos mutirões de ações judiciais de retificação de nome civil promovido pela ONG Igualdade RS101 e o grupo G8 Generalizando de Porto Alegre102.

Este documento, PRRC, tem como base a defesa da não patologização da identidade trans, o fim da utilização de um CID, mas, ao mesmo tempo, ele colabora com a demanda do judiciário. Tal documento ressalta também relatos de participantes sobre o sofrimento diário por ter esse direito negado e é utilizado nos processos das beneficiárias do programa e de outras que são atendidas pelo centro de cidadania LGBTQIA.

\footnotetext{
${ }^{100}$ Segundo o site http://www.blogsegurancadotrabalho.com.br/2015/04/o-que-e-cid.html, CID é a sigla para Classificação Internacional de Doenças e Problemas Relacionados com a Saúde.

${ }^{101}$ Link para site da ONG http://www.aigualdaders.org/

${ }^{102}$ Site do Grupo http://g8generalizando.blogspot.com.br/
} 
Outra ação do programa que permeia o cotidiano das beneficiárias realizado pela equipe psicológica é o acompanhamento do tratamento hormonal, que se deu também com a influência na implantação da hormonioterapia nas Unidades Básicas de Saúde no município de São Paulo. O processo de redesignação sexual, fruto das reivindicações dos movimentos LGBTQIA, é oferecido pelo Sistema Único de Saúde (SUS) desde 2008 através da Portaria GM/MS no 1.707103 e SAS/MS n 457104 e foi redefinido e ampliado em 2013 pelas portarias GM/MS n' 2.803105, que expandiu o número de serviços licenciados e ampliou o número de procedimentos realizados, desde a atenção básica até a especializada.

Esse atendimento de atenção básica em São Paulo é realizado nas Unidades Básicas de Saúde (UBS), e, em 2015, a Secretaria Municipal de Saúde de São Paulo definiu que as 9 UBS do centro da região passariam a ofertar o tratamento de hormonioterapia, as primeiras pacientes foram, justamente, as pessoas participantes do TransCidadania. Das 221 (considerando as que foram desligadas), mais de 60\% integraram e integram o tratamento de hormonioterapia, das 39,4\% que não integram, a maioria é por questões de saúde, por estarem no processo de aquisição de vaga ou por opção pessoal.

Segundo relatou durante a entrevista Clair Aparecida, psicóloga, esse acompanhamento não se deu apenas encaminhando as pessoas participantes, mas trabalhando em conjunto com as UBS na capacitação para atendimento ao público, na aproximação com as beneficiárias e no entendimento das problemáticas das pessoas participantes em relação às UBS. Esse processo possibilitou a criação de um fluxo de aprendizagem onde as pessoas participantes de 2016 já conseguiram ter um acompanhamento de processo na relação entre programa e UBS mais maduros, menos conflituoso e mais eficiente

\subsection{Os resultados do programa segundo balanço oficial do TransCidadania.}

Conforme exposto nos capítulos anteriores, o programa TransCidadania está dividido em três eixos principais: Autonomia, Oportunidade e Cidadania.

\footnotetext{
${ }^{103}$ Ver portaria http://bvsms.saude.gov.br/bvs/saudelegis/gm/2008/prt1707 1808 2008.html ${ }^{104} \mathrm{Ver}$ http://bvsms.saude.gov.br/bvs/saudelegis/sas/2008/prt0457 1908 2008.html

${ }^{105}$ Ver portaria http://bvsms.saude.gov.br/bvs/saudelegis/gm/2013/prt2803 1911 2013.html
} 
Por Autonomia entende-se, segundo a Nota Conceitual do Programa, "a garantia de condições de autonomia financeira, que possa possibilitar estabilidade para a consecução de capacidade e habilidade consideradas pela sociedade como necessárias à inclusão econômica e social".

Quanto ao que caracteriza Oportunidade, refere-se às articulações para promover capacitação escolar e profissional voltadas para o mercado de trabalho.

Cidadania tem relação com as ações desenvolvidas para a formação de uma consciência cidadã, permitindo às participantes estarem cientes dos seus direitos conquistados e que ainda são negados, e engajamento no debate das lutas que estão em curso por mais direitos.

As ações que compõem cada eixo podemos ver abaixo na tabela:

Quadro 1- Eixos e ações do programa TransCidadania

\begin{tabular}{|c|c|c|c|}
\hline & \multicolumn{3}{|c|}{ Eixos do Programa TransCidadania } \\
\hline & 1 Autonomia & 2 - Oportunidades & 3- Cidadania \\
\hline \multirow[t]{5}{*}{ Ações } & $\begin{array}{l}\text { POT } \\
\text { TransCidada } \\
\text { nia }\end{array}$ & Educação Básica & Respeito ao nome social \\
\hline & $\begin{array}{l}\text { CAD Único e } \\
\text { PBF }\end{array}$ & ENEM & $\begin{array}{l}\text { Curso de extensão universitária } \\
\text { Cidadania, Direitos Humanos e } \\
\text { Democracia }\end{array}$ \\
\hline & CRAS & PRONATEC & $\begin{array}{l}\text { Plano Individual de Participação } \\
\text { Social }\end{array}$ \\
\hline & & $\begin{array}{l}\text { Curso de introdução } \\
\text { ao mundo do } \\
\text { trabalho }\end{array}$ & \\
\hline & & Estágio & \\
\hline
\end{tabular}

Fonte: Nota Conceitual do TransCidadania

O programa TransCidadania teve diversos ajustes ao longo dos seus dois primeiros anos de vida, passando a incluir ações que inicialmente não estavam previstas no escopo, mas que no dia a dia se mostraram necessárias. Estas foram: parceria com o abrigo para mulheres Trans, a formulação do PRRC, a contribuição na implantação dos demais centros de referência na capital de São Paulo, que resultou na expansão para a Zona leste, Sul e Norte, o acompanhamento na hormonioterapia e o acompanhamento psicológico. 
Assim como determinadas práticas foram incluídas, alguns termos que estavam previstos na documentação inicial do programa e no contrato das pessoas participantes não conseguiram ter êxito, ou, ao menos, sair do papel, tal como o PRONATEC, a capacitação ao mundo do trabalho e estágio para todas beneficiárias. No segundo balanço da equipe do TransCidadania, divulgado sobre os dois primeiros anos do programa, as informações giram em torno da escolaridade, que é o ponto máximo do programa, da moradia e dos acompanhamentos psicossociais.

Durante os dois primeiros anos de vida programa, a análise mais completa se dá sobre o desenvolvimento escolar, principalmente em relação à turma ingressante de 2015. De acordo com os dados, das 100 primeiras beneficiárias no início do programa, 73 pessoas participantes $(87,95 \%)$ cursaram o ensino fundamental, sendo que 25 $(30,12 \%)$ concluíram o ensino fundamental ainda em dezembro de 2015 , e entraram para o ensino médio. Em relação às participantes que ingressaram no Ensino Médio, eram cerca de $13 \%$, e desse percentual $2,4 \%$ concluíram o curso em dezembro de 2015. Das que estavam cursando o ensino médio, 100\% participaram do Exame Nacional do Ensino Médio - ENEM. 
Figura 6 Gráfico sobre evolução escolar das participantes ingressantes em 2015

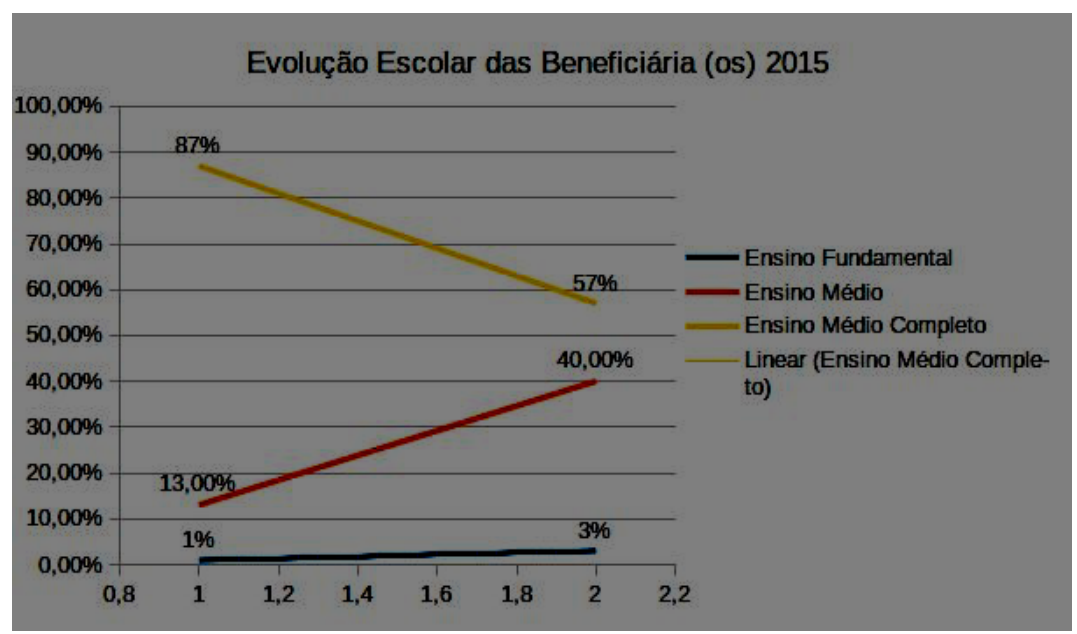

Fonte: Balanço 2015 - 2016 do Programa TransCidadania. Prefeitura de São Paulo.

Entre as participantes que continuaram estudando, percebeu-se que o número de pessoas participantes de ensino fundamental e ensino médio ficou equilibrado: $59 \%$ continuaram matriculadas no ensino fundamental e $37 \%$ frequentaram ensino médio. Das que se matricularam no Ensino Médio, 25\% ingressaram no $2^{\circ}$ ano, 3\% ingressaram no $3^{\circ}$ e cerca de $4 \%$ concluíram totalmente. No total, $33 \%$ das beneficiárias concluíram seus estudos, seja o ensino fundamental ou ensino médio.

Da turma que ingressou em janeiro de 2016, ainda de acordo com o balanço final do programa, $73 \%$ foram matriculadas no ensino fundamental e $27 \%$ no ensino médio. Em junho106, 14\% haviam sido aprovadas para o $2^{\circ}$ ano do ensino médio, $4 \%$ para o $3^{\circ}$ ano e $5 \%$, o equivalente a 9 beneficiárias, concluíram o ensino médio. No total, em dois anos de programa - no que diz respeito a escolaridade básica - foram matriculadas no ensino fundamental, 130 das participantes e, destas, 25 concluíram o curso. No Ensino Médio, foram 64 matriculadas, das quais 8 concluíram o ensino médio.

De acordo com o balanço do programa o número de evasão escolar nesse período foi de $6 \%$, o que significa 16 das participantes. Entre os motivos estão abandono (1\%), desistência (3\%) e impossibilidade de permanecer no programa. A diferença que o programa TransCidadania faz entre abandono e desistência está na comunicação com a equipe do programa.

${ }^{106} \mathrm{O}$ balanço não demonstrou dados de conclusão no final de dezembro. 
Quanto às assistências psicossocial, habitacional, jurídica e acompanhamento na hormonioterapia, os resultados são mais satisfatórios do ponto de vista quantitativo. Em relação à moradia, o programa classifica as pessoas participantes residentes em casas própria, alugada, cedida, ocupada, em situação de rua 107, abrigadas (albergues, centro de acolhida) e desabrigadas.

Os dados no cadastramento das pessoas participantes no que se refere à situação de moradia no início do TransCidadania 25 possuíam casas próprias, 133 alugadas, 21 cedidas, 8 ocupadas, 34 em situação de rua, 27 albergadas e 7 desabrigadas. Segundo o balanço, desta primeira turma o número de pessoas desabrigadas foi reduzido a zero. Das beneficiárias de 2016, das 25 que estavam em situação de rua, 12 foram acolhidas em equipamentos públicos e 13 se encontram em moradia fixa.

Quanto ao acompanhamento na hormonioterapia, das 221 das participantes, 134 integram o tratamento e 87 não integram - pelos mais diversos motivos, desde impossibilidade de saúde, aguardando vaga e/ou por não quererem ingressar no tratamento. No atendimento jurídico de assistência ao acesso à documentação civil, percebe-se que o número de pessoas que desejam trocar os documentos é quase igual ao número de pessoas que não desejam, também por motivos diversos. Alguns motivos podem ser sugeridos: desde o cansaço de tentar conquistar esse direito à não ter problemas com o nome de registro, mas essa análise foge do escopo deste trabalho. No TransCidadania, os dados mostram que $4 \%$ já possuíam o nome retificado quando ingressaram no programa, $55 \%$ estão em processo de retificação e $41 \%$ não tem interesse.

Outros serviços, no entanto, que estavam previstos no escopo do programa e contrato não conseguiram ser efetivados, entre eles estão o PRONATEC TransCidadania, curso de introdução ao mundo do trabalho e estágio. Para Zanelli e Silva (1996) a questão da profissionalização e trabalho são críticas pois:

${ }^{107}$ Que vive em albergue ou em hotel social e está no limite de ficar na rua 
Se, para a sobrevivência, o trabalho deveria satisfazer pelo menos as necessidades básicas diárias, na perspectiva psicológica é uma categoria central no desenvolvimento do autoconceito e uma fonte de autoestima. É a atividade fundamental para o desenvolvimento do ser humano. Em suma, é um forte componente na construção da pessoa que convive bem consigo mesma, acredita e orgulha-se de si (Zanelli e Silva, 1996, p. 21).

De acordo com o Coordenador de Políticas LGBTQIA, Alessandro Melchior, a questão da empregabilidade não estava ao alcance da política diretamente. Não cabia ao programa conseguir vagas de emprego em empresas para as pessoas participantes, mas de promover a capacitação das mesmas para que pudessem participar de processos seletivos e terem maiores chances no mercado de trabalho, essa capacitação envolvia o estágio previsto no programa.

Dado que a "mais autonomia" é um dos pilares conceituais do programa, a questão da Empregabilidade seria de extrema importância para garantir o desenvolvimento pós TransCidadania das pessoas participantes, contudo, os dois primeiros anos do programa não garantiu esse aspecto.

Quanto a esse assunto Symmy Larrat afirma que: 
Então, não é objetivo do Programa empregar, a gente não pode se dar esse objetivo, a gente prepara para o mundo do trabalho e a gente quer encaminhar para o estágio. $E$ a gente quer... (...) às vezes as vagas que surgem são vagas para um nível superior do que nós temos aqui. A gente tem muita gente que vai terminar o fundamental e vai começar o médio e é por isso que eu falo que a gente precisa de mais de dois anos, entendeu? A gente por exemplo pensava que em dois anos a gente conseguiria terminar o médio. Não consegue, pra conseguir finalizar uma das duas etapas. $E$ às vezes a gente não consegue ter, aqui, a demanda que surge lá, entendeu? Porque as empresas que estão na pegada de empregar pessoas trans, tal, são empresas grandes, então quem vai é aquela trans que já superou, que está num nível superior, que já fez mil cursos, não é o nosso público, na maioria das vezes. Então o que que a gente quer, por exemplo, pra poder encaminhar pra estágios de empresas terceirizadas da prefeitura, porque a gente acha que não tem lógica elas estagiarem na prefeitura, entendeu? E aí tentar acompanhar com essas empresas, pra ver se absorvem depois. É uma saída que a gente está pensando (Larrat, 2006).

A questão da Empregabilidade tem sua relevância, sobretudo, pelo cenário de vulnerabilidade social que travestis e transexuais estão inseridas nessa questão, resultado de um mercado de trabalho transfóbico. Segundo a Associação Nacional de Travestis e Transexuais (ANTRA), "ainda que elas queiram arranjar um emprego com rotina, horário de trabalho e carteira assinada, o preconceito fica evidente quando elas se candidatam a uma vaga" (Lapa, 2013), tornando a inserção no mercado de trabalho baixíssima e, quando acontece, essas pessoas assumem os postos de trabalhos mais precarizados sem perspectiva de progressão qualitativa.

Então, por exemplo, tiveram pessoas aqui que bateram aqui na nossa porta que tinham um diploma e que não conseguiam inserção e que nos procuraram pra ter cidadania (Larrat, 2016)

Sobre desligamentos do programa, alguns desligamentos aconteceram ao longo do programa por motivos como: a evasão escolar, a impossibilidade de permanecer por incompatibilidade com os termos do POT $(3,5 \%)$ e impossibilidade de permanecer no programa por outros motivos (1\%). Essa porcentagem foi feita a partir do total de pessoas participantes do programa ao longo de 2 anos, ou seja, somando as 221 beneficiárias. 
Acerca da impossibilidade de permanecer devido à incompatibilidade com os termos no POT, $3(1 \%)$ pessoas não finalizaram o programa em dois anos, $5(2 \%)$ se desligaram porque conseguiram ingressar no mercado de trabalho e 1 por ter se mudado de município $(0,5 \%)$. Outras razões de desligamento foram: problemas de saúde (1, total de $0,5 \%)$ e comportamento inadequado (1, total de $0,5 \%)$.

Sobre o benefício econômico, o balanço aponta que 100\% das beneficiárias afirmam ter o programa como principal fonte de renda e $60 \%$ afirmam ter outras atividades complementares, entre elas principalmente a prostituição. Quanto a isso o programa se pronunciou que nunca colocou como critério que as pessoas participantes deixassem as suas atividades como prostitutas para participar do TransCidadania, principalmente levando em consideração a delicadeza da questão da Empregabilidade para pessoa trans*.

De toda forma, o programa TransCidadania entende como um avanço as pessoas participantes terem outras opções de trabalho, como acontece com as pessoas cisgênera normativas e deveria acontecer para qualquer pessoa independente de etnia, gênero, classe ou sexualidade.

Ainda perfeito? Não, mas nós estamos cutucando a ferida e já estamos vendo soluções, por exemplo, o próprio sistema funerário já nos procurou para mudar a lápide de travestis que são enterradas na cidade com o nome social. Estamos fazendo o levantamento de quantas têm no sistema funerário desse município, porque é um respeito para além, não só em vida, mas que isso fique, se perpetue. Imagina as colegas irem lá e ficarem vendo o nome civil o tempo inteiro, quer dizer, olha a abrangência que nós tivemos nessa rede. Nós temos um CRM que veio debater conosco pra gente construir um fluxo de atendimento a mulheres trans vítimas de violência doméstica. Então, assim, a gente está deixando equipamentos que vem para cá e, infelizmente, nós só temos um ano e sete meses, e dez meses de Programa, não, e nove, porque a gente começou em final de janeiro, então temos um ano e nove meses de Programa. Ainda não é muito tempo, a gente pode pensar que o que a gente avançar é pouco, mas falando de gestão, um ano e nove meses, nós revolucionamos muitos espaços e a gente pode revolucionar muito mais pela abrangência que o Programa tem, o Programa consegue chegar em escolas, na periferia, amanhã eu vou estar no CEU Heliópolis falando sobre identidade de gênero para não sei quantos professores. Então assim, gente acabou sendo referência nesse debate e a galera quer conhecer (Larrat, 2016) 


\title{
6 SOB UM NOVO OLHAR: AS ENTREVISTAS.
}

\author{
Já fui loura, já fui morena \\ ,já fui Margarida e Beatriz. \\ Já fui Maria e Madalena. \\ Só não pude ser como quis. \\ (Cecília Meireles)
}

Quando me propus a analisar as metas do programa, tinha como primeira informação que elas consistiam na efetivação da cidadania através da educação formal e capacitação profissional, repassando um auxílio financeiro para viabilizar a participação das pessoas participantes. Logo, seguindo a Nota Conceitual do programa - primeiro documento oficial sobre o mesmo - estabeleci como meta analisar o ensino formal, os cursos de capacitação profissional e os cursos de direitos humanos, assim como verificar se o auxílio financeiro teve significativa importância nesse programa.

Entretanto, constatei que o programa, ao longo de dois anos, foi modificando seu escopo, principalmente quanto ao seu principal objetivo. Algumas ações previstas, como a capacitação profissional, foram colocadas para um próximo momento do Programa à medida que a equipe verificava as possibilidades e limites do TransCidadania. A parceria com o PRONATEC (O Programa Nacional de Acesso ao Ensino Técnico e Emprego) do Governo Federal, não aconteceu. Outras iniciativas, como tentativas de parcerias com empresas locais, foram viabilizadas, mas com pouca efetividade. 
Apesar do foco do programa ao final ter se situado na escolaridade formal básica, outras metas do programa relacionadas à violência, empregabilidade, conjuntura política, relacionamentos familiares, que surgiram ao longo das entrevistas também serão analisadas, pois elas fazem parte da constituição dessas pessoas como cidadãs e podem impactar diretamente na educação formal.

O cenário geral, quando se analisa os dois anos do programa, não é de desilusão e sim de constatação de que quando uma política têm os investimentos e a atenção do poder público necessários, ela pode alcançar êxito em suas metas, como foi caso a meta da educação, que se trata tanto da educação formal quanto dos cursos de cidadania e direitos humanos ministrados às participantes.

\title{
6.1. O cotidiano e os encontros de um programa pioneiro: Algumas observações.
}

\begin{abstract}
A travesti que foi ao encontro de jovens que vivem com HIV/aids citado no início deste artigo ao confrontar-se com a necessidade de preencher a ficha de entrada no hotel, interpelou-me: Você pode escrever o meu nome para mim? Aos 18 anos estava fora da escola e não sabia escrever o próprio nome (ou o nome próprio?). No cotidiano, tematizamos seu banheiro, mas não sua expulsão velada e os resultados deste processo em sua vida, seja em termo analfabetismo, dificuldades com a escolaridade ou ainda em relação ao que poderão dizer de si mesmas. Por que a o banheiro a ser utilizado por uma travesti pode gerar mais polêmica do que o fato de que as escolas podem estar contribuindo para a exclusão (explicita ou implícita) de travestis? (Cruz, 2011, p.80).
\end{abstract}

Para Mainardes (2006, p.50) ao analisar uma política deve-se considerar uma multiplicidade de aspectos tais como: a estrutura social; o contexto econômico, político e social no qual as políticas são formuladas; as forças políticas; e a rede de influências que atuam no processo de formulação de políticas e de tomada de decisões nas diferentes esferas.

De acordo com Whyte (2005), uma pesquisa pode implicar num processo longo, de meses de "negociação" para se ter acesso ao campo a ser estudado. Esta negociação de entrada, neste trabalho, começou com as trocas de e-mails com André Luiz - na época Coordenador Adjunto de Políticas LGBTQIA da Secretaria de Direitos Humanos no Município de São Paulo -, primeiras tentativas de negociar minha entrada e acompanhamento do programa TransCidadania. 
Porém, ser recebida pela equipe de maneira satisfatória e poder compartilhar minhas intenções e projetos com gestores não significava estar inserida no meio das pessoas participantes, em seu cotidiano. Rapidamente percebi que o acesso ao universo das pessoas trans* que participavam do TransCidadania não se daria da forma simples e rápida que se deu a troca de e-mails. Foram seis reuniões com a equipe e a maioria delas abordavam quem eu era, qual o meu projeto e quais minhas intenções. Esse processo envolveu, inclusive, uma conversa mais profunda sobre o programa com a coordenadora da época, Symmy Larrat.

Essas conversas se deram, em sua maioria, na sede do programa TransCidadania. Recém-localizada na Rua do Arouche, no centro de São Paulo, a sede era uma ampla sala no $4^{\circ}$ andar, onde, desde a entrada, era possível notar uma enorme diferença em relação aos demais andares do prédio. O andar estava sempre movimentado pelas participantes, pessoas que iam até o local em busca de informações ou atendimentos para pessoas trans*, estudantes e acompanhantes das pessoas participantes do TransCidadania.

No início dessa aproximação Symmy Larrat, de maneira extrovertida, deixou nítido para mim que eu teria que "fazer por merecer"108. Então, ela propôs que, antes de realizar as entrevistas - que classificou como contato direto -, era necessário que eu conhecesse mais a dinâmica do programa e das pessoas participantes. Me sugeriu que eu acompanhasse algumas das atividades, tanto para que pudesse ter uma melhor perspectiva do TransCidadania, quanto para que elas se acostumassem com a minha presença. A coordenadora do programa tinha um enorme receio de provocar um mal-estar entre as pessoas participantes com o processo de pesquisa. De fazêlas se sentirem "ratinhos de laboratório", como definiu.

${ }^{108} \mathrm{Ou}$ seja, que para eu pudesse conquistar o direito de fazer entrevistas com as pessoas participantes do programa com sua aprovação, eu deveria demonstrar que não queria usar as pessoas participantes apenas para coleta de informações. 
Symmy Larrat me propôs um procedimento metodológico chamada observação participante e, além disso, uma oportunidade única de acompanhar com mais qualidade meu objeto de pesquisa, o programa TransCidadania. Após muitas trocas ao longo de quase 2 horas de conversa, a coordenadora despertou minha curiosidade sobre si mesma. Ela mesma uma travesti, militante do movimento trans*, nascida em Belém do Pará, com uma trajetória de vida entre empregos e desempregos e tentativas de sobrevivência. Sua perspectiva sobre o programa seria muito enriquecedora.

Symmy Larrat é uma militante que iniciou seu contato político em Belém, se articulando ativamente com diversos setores do movimento e secretarias LGBTQIA. Desenvolveu um forte papel dentro do movimento trans ${ }^{*}$ e, por sua atuação e trajetória, foi convidada para trabalhar no Governo Federal dentro da Coordenação LGBTQIA. Saiu para assumir o TransCidadania a pedido do Prefeito Fernando Haddad. A história pessoal de Symmy, que me foi compartilhada naquele momento, é marcada por altos e baixos até a projeção em sua atuação e, com isso, a obtenção de posições nas gestões públicas. Uma história de oportunidade, o que demonstrou ser sua expectativa em relação ao TransCidadania.

A partir de então foi definida uma agenda onde eu visitaria o programa quinzenalmente para conversas periódicas com assistentes sociais, pedagogas, psicólogas, assistentes de coordenação, bem como o acompanhamento de algumas aulas dos cursos oferecidos, rodas de conversa e visitas guiadas das pessoas participantes em locais públicos da cidade, onde eram realizadas aulas públicas. Umas dessas visitas foi à Câmara Municipal de Vereadores de São Paulo, onde as pessoas participantes tiveram uma aula sobre Direitos Humanos e Cidadania, participaram de uma audiência pública e visitaram os demais espaços do local.

Valladares (2007, p. 154 apud Whyte, 2005) afirma que "O pesquisador é um observador que está sendo todo o tempo observado", e, na ocasião da visita guiada à Câmara Municipal de Vereadores, era possível perceber pelos rostos e gestos o estado de espírito das pessoas participantes daquela aula, em sua maioria ansiosas para falar sobre sua vivência para o ministrante do curso. 
Durante o período que acompanhei o programa TransCidadania as pessoas participantes me observavam, falavam entre si, e algumas, impulsionadas pela curiosidade sobre aquela pessoa que as acompanhavam, puxavam conversa na tentativa de entender qual o meu papel ali. Busquei sempre responder da maneira mais objetiva possível.

Algumas se limitavam a estabelecer o contato apenas através de "oi" e sorrisos, outras, em conversas nos corredores da sede do programa e demais lugares que frequentei com elas. Nesse sentido, as redes sociais, em especial o facebook ${ }^{109}$, ocuparam um lugar privilegiado nessa aproximação, fosse para iniciar um contato mais efetivo, ou para ampliar os contatos em suas redes sociais.

Participar desses momentos me possibilitou observar as pessoas participantes e suas dinâmicas de relação. Escutar algumas de suas histórias, planos e preocupações com o futuro. As pessoas participantes que me diziam estar juntando o dinheiro do POT para comprar uma casa na sua cidade natal, para ajudar tratamentos familiares ou, até mesmo, para custear seu plano de casamento.

Tive uma compreensão maior sobre como suas rotinas haviam mudado, pude observar os agrupamentos, as falas de rinchas 110 com outras pessoas participantes, e, principalmente, notar que, ao começar a habitar no programa, elas também faziam dele uma extensão dos lugares com os quais se identificavam:

\footnotetext{
${ }^{109}$ Facebook é uma rede social que permite a ligação de pessoas através de uma plataforma digital, permitindo a troca de interações como compartilhamento de fotos e notícias, e conversas simultâneas on-line.

${ }^{110} \mathrm{De}$ acordo com o dicionário informal, rincha significa quando alguém tem algum atrito, desavença com outra pessoa http://www.dicionarioinformal.com.br/rincha/
} 
Aqui é o lugar que a gente tem proteção (...) A gente é acolhida. Aqui a gente não tem preconceito, não vê aquelas pessoas, assim, com olhar, assim, de nojo, porque eles ${ }^{111 *}$ sentem nojo da gente, eles ${ }^{* * 112}$ tratam a gente como se fosse aberração, como se fosse monstro (Xavier, 2016)

Entretanto esse período de observação foi interrompido nos primeiros meses de 2016 devido às trocas de coordenação do programa, incluindo períodos em que esta esteve ausente. Com isso, foi necessário um novo processo de aproximação do programa e, desta vez, com maior dificuldade. O TransCidadania estava entrando num novo ciclo uma vez que a nova coordenação adotou novas metodologias em relação à própria dinâmica do programa - que havia completado um ano e incluído novas cem pessoas participantes - e de contato com a academia.

A mudança de coordenação e o período de ausência da mesma, refletiu no programa de diversas maneiras, tanto para aqueles que se aproximavam do programa, quanto para a equipe técnica e as pessoas participantes. Essas mudanças alteraram as relações que se davam no projeto e tiveram aspectos positivos e negativos.

111* Eles que Christine se refere são as pessoas de modo geral da sociedade, para fora do espaço do TransCidadania.

112** Idem. 
A gente com a Symmy, mas três meses ou quatro mais ou menos, ela sai (..) nós ficamos começa sem coordenação geral, apenas com assistente de Coordenação (..) a equipe tem uma movimentação muito dinâmica (..) E ai a gente sempre problematizando as coisas e fazendo, pensando e fazendo... (...) Aí veio a Juni. A Juni veio num movimento de nos aproximar mais com a academia, de fazer bastante coisa com academia (..) Ai a equipe se modela novamente pra ficar no formato com a Juni que chega numa outra visão (...) A juni saiu, foi um luto absurdo... A gente fica quase maluco (tem coisas que não é da nossa competência, e sim de um coordenador), então a Koinonia se faz muito mais presente e nos dá um suporte. A Symmy volta. Por que ela chega com uma fortaleza e com leveza, ela consegue nos passar segurança e nos ouve (Aparecida, 2016)

Desde o momento que eu entrei todo mundo falava bem da Symmy. Mas eu senti que não só as meninas, mas como a equipe deu uma baqueada ${ }^{113}$ quando a Juni saiu (..) muita coisa parada. A gente não sabia o que fazer. As meninas de 2016 sentiram mais (Nolasco, 2016)

Eu não acho que foi ruim para o Programa, eu sinto algumas ausências, entendeu? E a minha afinidade com o Programa, a minha relação pessoal com o Programa me faz questionar inclusive se eu devia ter saído ou não, eu me coloco nesse lugar. Só que eu acho, também, que algumas, a gente não conseguiu mais por conta também de que nós estávamos fazendo pela primeira vez, o segundo ano do Programa já foi um ano eleitoral, isso é muito complicado, o ano eleitoral, para a gestão, é um ano muito complicado. Se nós tivéssemos, por exemplo, finalizado o primeiro ano, lançado o Programa no segundo ano de gestão, não teríamos tido essa dificuldade toda (...) Impactos tiveram, tiveram impactos, eu acho que eles não foram tão profundos por conta de que ele era um Programa do prefeito, então as coisas meio que se resolviam, entendeu? Mas tiveram, por exemplo, alguns impasses, alguns entraves, por conta dessas idas e vindas (Larrat, 2016).

A troca de coordenação de um programa de gestão não é um caso isolado. É comum ocorrerem mudanças de acordo com o interesse do gestor ou com os fatos políticos. Symmy Larrat justifica sua saída pela demanda do movimento trans* nacional, após a extinção da coordenadoria LGBTQIA do Governo Federal. Para Symmy, neste momento, os setores da militância precisavam pensar novos rumos da luta por políticas públicas e, para isso, precisavam de lideranças políticas que tivessem escopo.

Assim como sua saída, seu retorno também se deu a partir de alterações no cenário político: ela retornou ao programa depois da troca de governo no âmbito federal, resultado do processo de impeachment114. 
Para Symmy, uma das principais dificuldades enfrentadas neste período de trocas e ausência de coordenação foi a questão da representatividade. Para ela, o fato de as pessoas participantes conseguirem se reconhecerem e se relacionarem com ela, sendo travesti e fazendo parte da população trans* ${ }^{*}$ facilita a comunicação e a boa relação entre a coordenação e as pessoas participantes.

A Symmy era uma referência pra elas. A Juni é uma mulher cis. (...) Elas vão pedindo resposta e nós sem coordenação (Aparecida, 2016)

A representatividade das pessoas beneficiárias, elas têm um outro nível de representatividade comigo, elas falam direto comigo e elas percebem que eu vou entendê-las por eu ser uma travesti. Esse é um diferencial que eu acho que dá, tranquilamente a gente pode falar. A identificação, sabe, eu acho muito difícil alguém conseguir tocar o TransCidadania não sendo trans e conseguir manter uma relação de proximidade com as beneficiárias. (...) Então isso acontece pro bem e pro mal, mas acontece mais pro bem, porque é uma questão de representatividade, elas se veem onde elas se miram, muitas vezes, sabe, é uma responsabilidade muito grande, porque as pessoas se miram em mim e eu não sei se elas devem se mirar em mim, porque eu não sou uma pessoa concursada, eu não conquistei esse espaço, eu estou nesse espaço, eu não conquistei esse espaço. Quando o TransCidadania acaba eu volto pra esquina, igual todas elas. Até que ponto eu sou menos vulnerável que elas? Eu não sei se eu sou menos vulnerável que elas, entendeu? Não estou me vitimizando, mas estou fazendo uma análise estou, (...) Então até que ponto eu sou absorvida ao término do TransCidadania? Ou eu correndo o mesmo risco que elas? Entendeu? Então elas percebem que a gente está no mesmo jogo e às vezes elas se miram e eu acho que essa responsabilidade é muito grande, muito pesada pra mim, (...) Então são questionamentos que ficam, mas eu acho que a questão era essa, a identificação delas com uma pessoa trans que fala a linguagem delas é completamente diferente (Larrat, 2016)

Durante o processo das entrevistas, não houve nenhum impedimento quanto à marcação e realização das conversas, a não ser alguns ajustes de agenda. Nenhuma das pessoas participantes demonstrou resistência ao processo, pelo contrário, muitas que não participaram das reuniões, se mostraram curiosas e interessadas. O processo de observação que antecedeu as entrevistas representou um papel importantíssimo, uma vez que me proporcionou uma maior confiança nas perguntas que eram feitas e nas respostas que escutava.

\footnotetext{
113 Expressão utilizada quando quer se referir que algo caiu um pouco de qualidade, ficou triste. http://www.dicionarioinformal.com.br/baqueada/

${ }^{114}$ No primeiro semestre de 2016 a Presidente Dilma Rousseff foi alvo de um processo jurídico e parlamentar que culminou no processo de impeachment do seu mandato.
} 
Entre a angústia sobre o futuro do programa, a euforia de participar de um trabalho acadêmico, a emoção ao lembrar do passado de relatar o presente, a demonstração da vontade de vencer na vida, as entrevistas foram um processo complexo de aprendizagem sobre a vida de mulheres travestis e transexuais numa cidade como São Paulo.

A proximidade e o diálogo com essas pessoas me levaram a entender a responsabilidade que é desenhar programas para lidar com vidas que estão acostumadas com o descaso e negligência e, agora, dão a oportunidade para si e para o Estado de realizar algo que as faça acreditar nessa sociedade que, de acordo com os relatos, tanto as machucam. Todos os relatos foram anexados como transcrições sequenciais no apêndice deste trabalho.

A preocupação com o futuro delas, das outras travestis e transexuais que ingressaram no último período do programa e das demais na fila de espera, eram evidentes em todas as falas, incluindo as do corpo técnico. Uma preocupação que aparentava transpor a simpatia com uma gestão em si e que estava mais relacionada com ter vivenciado uma experiência inédita de iniciativa do poder público.

O período de observação se encerrou no evento de formatura do ciclo de dois anos das ingressantes de 2015 e a conclusão de um ano das ingressantes de 2016. A cerimônia foi realizada na sede da prefeitura de São Paulo e, diferente da primeira formatura - que foi coberta por diversos veículos da imprensa, com direito a baile e traje de gala - esta foi mais modesta. Apesar do clima de despedida de ambas equipe e gestão, as falas das pessoas participantes eram de celebração e gratidão, além de uma óbvia preocupação com o futuro.

\subsection{Para além de indicadores: Análise das entrevistas.}

A seguir, serão analisadas as entrevistas realizadas.

\subsubsection{Violência}


Nesta seção foco em analisar não somente os indicadores assinalados pelo balanço oficial do programa TransCidadania. Quero analisar através dos relatos das experiências vividas pelas pessoas envolvidas, principalmente as pessoas travestis e transexuais atendidas pelo programa. Esses relatos foram sistematizados num mapa onde alguns eixos foram destacados como: violência, educação, empregabilidade e conjuntura política. É principalmente sobre esses eixos que está seção irá tratar.

O primeiro eixo a ser analisado é a Violência Física. Este tema foi sugerido após um processo de reflexão, já que, infelizmente, a violência transpassa quase todos os eixos selecionados, seja ela física ou simbólica.115. Aqui, especificamente, me aprofundei na violência física, presente na maior parte dos relatos das pessoas participantes em relação à seu cotidiano e a necessidade de cuidados do poder público. Suas falas revelam o medo de frequentar espaços públicos como banheiros, a violência policial, a violência na rua e a pressão que recai sobre elas, levando muitas a depressão e suicídio como alternativas.

E você se vê numa situação de rua, tem que ir pra rua, é travesti, travesti na rua. E você viver numa prostituição, momentos que você ri, momentos que você chora, momentos que você corre risco, momentos que você olha pro céu, olha pra noite, pede a Deus pra te tirar dali, mas não tem saída, é ali que você tem que ficar. Você vê amigas chegando, amigas morrendo, correndo risco de doenças, de tudo que não presta, pelo simples objetivo de sobreviver (Marques, 2016)

Mesmo tendo particularmente optado por não focar na violência durante o processo de pesquisa, por não querer contribuir na narrativa que torna a violência quase que a extensão do ser de uma pessoa travestis ou transexual, a palavra violência surgiu diversas vezes nos relatos das pessoas participantes sobre seu cotidiano, e por tanto, não podendo ser ignorada.

A violência relatada, seja em casa, ainda no ambiente familiar, seja na rua, em uma simples ida em um estabelecimento comercial, resulta em olhares e xingamentos; $A$ escola, espaço que todos têm o direito de ocupar, na maior parte das vezes nega às pessoas entrevistadas seu direito à identidade e se torna hostil, exclusão afirmada e reafirmada diversas vezes por funcionários e alunos.

\footnotetext{
${ }^{115}$ Bourdieu (2012) define como violência simbólica a forma de violência exercida sem coação física, em que causa danos morais e psicológicos.
} 
Quando uma pessoa trans* ingressa no processo seletivo para uma vaga de emprego, de acordo com as entrevistas, o descarte ocorre, muitas vezes, antes mesmo da entrevista, e isso também se constitui uma violência; outros lugares como os postos de saúde não respeitam seus nomes e gênero.

Há, portanto, nas mais diversas esferas da vida, a ausência de tratamento humanizado e a negação dos seus direitos mais básicos como qualquer cidadão, que como exposto no início deste trabalho são direitos básicos de qualquer cidadão.

A entrevistada Marques se refere à violência física que sofre em seu local de trabalho, a rua. O trabalho sexual é o espaço que a sociedade "tolera" a travesti e, não sem razão, que Aline tem a sensação que ali é o local que se "tem que ficar". E ali ela é violentada de diversas maneiras, na maior parte das vezes por clientes que a agridem fisicamente, se recusam a usar o preservativo, ou forçam a relação sexual. Não raro, essa violência leva à morte, o que coloca o Brasil no topo do ranking dos homicídios por transfobia no mundo.

Por ser corriqueira, essa violência desenvolve o medo que as pessoas trans* tem de circular nos espaços públicos. Mesmo que estejam cientes de seus direitos, eles não são o suficiente para garantir a segurança dessa população.

Se bem que até hoje eu ainda tenho receio de usar o banheiro, porque eu tenho medo de apanhar, não nego (Martinez, 2016).

O participante, um homem trans ${ }^{*}$, destaca que a violência policial tem características específicas quando se trata de uma pessoa transexual, já que é somada à violência à sua identidade de gênero:

Eu não confio, já tomei bastante enquadro, eu acho que eu tenho cara de maloqueiro, eu não sei. Se eu tiver, eu gosto. Mas eu já tomei bastante enquadro e, tipo, não é legal, você é mais humilhado do que os caras cis que tomam enquadro com você. (...) Porque aí o cara te revista, ele começa a gritar no meio da rua pra todo mundo ouvir eu não pus a mão na sua boceta, não, viu? Você não quer ser homem? Vai apanhar que nem homem. Será que essa é a preparação que eles estão tendo? (Martinez, 2016)

Para Xavier a violência e o preconceito que travestis e transexuais sofrem são as principais causas da depressão e do suicídio. 
Tem travesti até que se mata porque é muita pressão em cima dela, é muito preconceito em cima dela, que ela não suporta, que ela cai na depressão, da depressão ela tenta um suicídio, tem vez que consegue e tem vez que não consegue, porque é muita pressão, é muita pressão, gente, vocês não têm nem noção do que a gente sofre (Xavier, 2016).

Carrara e Vianna (2006, p.237), em estudos sobre violência contra travestis e transexuais na cidade do Rio de Janeiro, sugerem que existe um quadro de investigações precário em relação à violência contra pessoas trans*, ainda mais se estas estiverem em situação de prostituição ou tráfico de drogas. Outro ponto que constatam é que muitos relatos de violência contra pessoa trans* são registrados como casos contra pessoas homossexuais, o que dificulta a visibilidade necessária de dados sobre a transfobia.

O programa TransCidadania não aborda diretamente a violência dirigida às pessoas trans $^{*}$, entretanto, investe na educação como forma de contribuir a longo prazo com esse cenário e auxilia ações de combate à violência, realizadas pelo Centro de Referência LGBTQIA, como campanhas, a marcha do orgulho LGBTQIA e as unidades móveis policiais especializadas para tratamento de pessoas trans*. Além disso, de acordo com o balanço oficial do programa, muitos dos atendimentos emergenciais que ocorrem na sede do programa são casos de violência e são encaminhados para os órgãos competentes.

As pessoas participantes apontam que os esforços de promoção de um ambiente seguro ainda são restritos ao espaço do TransCidadania, afirmando que ainda são necessárias mais ações e políticas que visem o combate à violência contra as pessoas trans*, inclusive do próprio programa. 
Sim, sim. Aqui é o lugar que a gente tem proteção, mas a gente não vai viver vinte e quatro horas aqui. A gente vai ter que correr atrás de emprego, a gente vai ter que correr atrás da maneira da gente sobreviver. E tem lugar que vai ter preconceito, que o preconceito a gente vê estampado na cara das pessoas, e vai ter lugar que vai nos acolher (Xavier, 2016)

Eu acho que, na questão da segurança, o que o Programa ajuda é mais dando a visibilidade. Porque, com visibilidade é capaz, não é certeza, mas é capaz que as pessoas entendam melhor (Martinez, 2016)

Dos relatos expostos, podemos concluir que a violência é um tema constante na vida das pessoas trans* e não pode ser ignorada nas análises feitas aqui. Ela se faz presente na forma que essas pessoas vivenciam a vida e, muitas vezes, é vista como um fato dado e não algo que pudesse ser evitado pela ação do Estado e outros órgãos.

\subsubsection{Educação}

Quanto ao aspecto da educação as entrevistadas relatam sobre suas experiências antigas nas escolas e os motivos pelos quais "abandonaram" 116 os estudos. Discorrem sobre o que significou a possibilidade de retornar para escola, os medos antigos, os incentivos que tiveram e, por fim, a entrada no programa. Como Educação é o eixo principal do programa TransCidadania, aqui relato as experiências delas no dia a dia da escola, dentro do programa, o que elas consideravam melhorias e seus planos.

Após diversas modificações do objetivo central do programa, ficou nítido que, apesar de não negligenciar demais áreas de vulnerabilidade, o principal ponto do programa de atuação era a questão da escolaridade.

A educação segundo Gadotti (1995):

\footnotetext{
${ }^{116}$ Coloco em aspas a palavra abandonaram porque existe a discussão, com a qual concordo, que essas pessoas não abandonaram simplesmente a escola, antes, foram expulsas pelo preconceito e violência cotidiana sofrida naquele espaço.
} 
(...) tem um papel importante no próprio processo de humanização do homem e de transformação social, embora não preconize que, sozinha, a educação possa transformar a sociedade. Apontando as possibilidades da educação, a teoria visa a formação do homem integral, ao desenvolvimento de suas potencialidades para torná-lo sujeito de sua própria história e não objeto dela. Além disso, mostra instrumentos que podem criar uma outra sociedade (p.18).

Ao analisar o trabalho de Bernstein (1996) sobre a importância da educação na construção de uma sociedade democrática, Santos (2003, p 23) ressalta que "educação, como a saúde, sendo bem público, tem um papel central na produção e reprodução das injustiças sociais".

Entretanto, a experiência traumatizante de uma pessoa no ambiente escolar, dado seus mecanismos de constante vigilância e não aceitação dos sujeitos diferentes da norma, na sala de aula, nos espaços privados como banheiro, nos espaços de convivência, dificulta a permanência no ambiente escolar para essas pessoas. Uma pesquisa realizada por Cruz (2011) sobre a o cotidiano de pessoas travestis e transexuais no ambiente escolar, e o "simples" ato de ir ao banheiro, demonstrou a gravidade do problema e constrangimento que essa população vive:

Nesta turma e em todas as outras que se seguiram abri este debate e pude perceber que as travestis têm muitas dificuldades no cotidiano da escola - desde a resposta da chamada, até o relacionamento com colegas, professores e direção. Sua diferença não é bem recebida no cotidiano da escola. E, tal qual gays, lésbicas, negros, portadores de HIV e todos aqueles tidos como os anormais, sua cidadania e direitos são frequentemente violados (Cruz, 2011, p. 74).

Para Cruz (2011) pensar nesse quadro dentro da escola se justifica pelas consequências que as ações educativas refletem na vida das pessoas, e também pela necessidade de promover e manter o ambiente escolar um espaço público, seguro, laico e que celebra as diversidades (p.80). 
Foi, eu estava em casa e uma amiga minha me falou. Ela falou, Felipe, você não terminou a escola, né? eu falei eu não. Ela pô, tem um projeto bacana pra gente, o TransCidadania, por que que você não vai lá? Aí você volta a estudar. Aí eu falei ai, Érica, estudar não. Não, não, não, eu não tenho boas lembranças de escola, não quero. Ela, deixa eu falar? eu falei, deixo. Meu, é um projeto só para transexuais, eles vão te respeitar como você é, vão te pôr numa escola que vão te respeitar, você não vai ter problema nenhum quanto a isso, vai receber uma bolsa pra ajudar você, aí você vai receber para estudar e ainda vai ser respeitado. Por que que você não vai lá ver? Eu falei, ah, sendo assim acho que dá pra dar uma olhada. Ela falou, vai lá. Aí eu vim no começo do ano, em janeiro. Aí não tinha vaga. Aí eu fiquei na fila de espera. Quando foi em junho eles me ligaram pra eu vir aqui que tinha surgido a vaga. Aí eu entrei e, graças a Deus, já estou quase terminando a oitava série (Martinez, 2016)

ai meu Deus do céu, será? Voltar pra escola, voltar a fazer curso? E aquela cicatriz que ficou lá? Dos dez, oito, nove anos de idade, de preconceito, apanhar de amigo, ser xingada, aquela coisa toda? A Atena, não, vai ser bacana, eu ai, sei lá. Aí eu parei e pensei, pelo menos eu vou voltar a estudar, eu não vou ficar parada, igual aqui. Aqui, se eu ficar dois anos eu vou sair com uma mão na frente e outra atrás. Lá, eu vou aprender, eu vou ter curso, eu vou ter uma oportunidade, quem sabe, né? (Marques, 2016)

As falas das pessoas participantes sobre suas trajetórias escolares revelam cenários de discriminação e violência, tornando-as receosas de retomar para a vida escolar. Não por acaso. A escola possui um mecanismo de vigilância que busca controle constante - ainda que não seja facilmente percebido -, a normatização e disciplinarização dos corpos. Esse processo é visto como "natural" e, na maior parte das vezes, não é questionado. Foucault (2013, p.143) entende que esse processo de vigilância cumpre o papel de domesticação dos corpos como forma de construir sujeitos normatizados.

Todos os espaços coletivos: sala de aula, pátio, banheiros gendrados, são vigiados e arquitetados de forma que controlem aqueles que frequentam esses espaços, mas esse controle assume um grau maior para aqueles que vão na contramão da norma. Por exemplo, os banheiros gendrados são ambientes de controle dos corpos sexuados, segregam por gênerolgenitália e vigiam como e quantas pessoas permanecem dentro de cada cabine individual. 
[...] todo espaço de visibilidade organizado com tanto cuidado (a forma, a disposição das latrinas, a altura das portas, a caçada aos cantos escuros) tudo isso, nos estabelecimentos escolares, substitui - para fazê-lo calar - o discurso indiscreto da carne que a direção da consciência implicava (Foucault, 2010, p. 202)

Porque eu ia pra escola? você não é respeitado como você tem que ser, não aceitam seu nome social, aí você fica passando constrangimento, você não vai no banheiro, porque não tem um banheiro que você possa usar, porque se ninguém me respeita como Felipe eu não posso usar o masculino, se eu entrar no feminino as meninas saem gritando. Aí eu tentei ainda algumas vezes, e falei, quer saber, vou comprar um histórico, não vou estudar mais não. Aí comprei, realmente, comprei um histórico (Martinez, 2016)

Essa vigilância que Foucault menciona - que é tão bem exemplificada nas palavras de Martinez - demonstra que existe uma vigilância dos corpos como um todo, e essa vigilância se dobra em relação às pessoas trans*, que, no limite, não conseguem espaço para realizar uma necessidade básica, pois passam a ser vigiados inclusive pelos outros usuários.

\begin{abstract}
A produção de seres abjetos e poluentes (gays, lésbicas, travestis, transexuais e todos os seres que fogem à norma de gênero) e a desumanização do humano são fundamentais para garantir a produção da heteronormatividade. A escola é uma das instituições centrais nesse projeto. (Bento, 2011, p. 544)
\end{abstract}

Assim, para essas pessoas, o processo de retornar para escola não é simples. É permeado por significados e experiências negativas. É necessário lembrar que a maioria das pessoas participantes do TransCidadania são mulheres trans e travestis com mais de 30 anos, periféricas, negras, que foram forçadas a deixar a escola, em média, há mais de 15 anos. Eis o desafio do programa e sua importância na vida dessas pessoas participantes: 
É, foi graças ao projeto que eu consegui estudar, porque eu não tinha saco pra ir à escola, essa que é a palavra correta (Martinez, 2016)

Eu parei na oitava série, não tive a oportunidade, assim, de estudar, porque o meu pai era alcoólatra, minha mãe era deficiente, minha mãe é deficiente, minha mãe é cega, e é eu e mais uma irmã, e minha irmã é mais nova do que eu, então a mais velha era eu. Então como o meu pai era alcoólatra e minha mãe é deficiente, sempre pesou aquilo de lá em mim e eu não tive uma oportunidade, eu tive que cuidar de casa, aprender a fazer comida, aprender lavar roupa, pra ajudar a minha mãe. Hoje, sim, eu estou tendo a oportunidade de estudar, porque anos se passaram, a minha irmã cresceu, minha irmã pode dar uma ajuda também pra cuidar da minha mãe, porque ela é deficiente visual, agora sim eu estou tendo a oportunidade de me formar, de estudar, entendeu? E eu não entrei no TransCidadania com o foco de arrumar emprego, eu entrei no TransCidadania pra estudar, pra me formar, pra fazer uma, como que eu posso falar, terminar os estudos pra me profissionalizar, entendeu? (Marques, 2016)

A conclusão do ensino formal foi considerada, pelas pessoas participantes, como uma vitória possibilitada e facilitada pelo TransCidadania. Talvez, no imaginário normativo, não haja nenhum obstáculo que impeça uma pessoa trans* de frequentar a escola, ainda mais naquelas onde é possível ser matriculada e responder na folha de frequência pelo nome social, inclusive para aqueles que ainda não passaram pelo processo de retificação do nome.

A experiência relatada pelas pessoas participantes, entretanto, mostra que é necessário muito mais que o respeito ao nome social para que uma pessoa trans ${ }^{*}$ se sinta acolhida na escola. Neste aspecto, é fundamental que exista uma equipe de profissionais de psicologia, pedagogia e assistência social, que assistam as pessoas participantes no dia-a-dia escolar. A existência desta equipe no programa TransCidadania contribui para a baixa taxa de evasão escolar de acordo com o balanço onde o número de evasão escolar foi de $6 \%$, contabilizando 16 pessoas participantes num total de 200.

Observa-se, nos relatos das entrevistas, que a possibilidade de concluir os estudos permitiu o planejamento de continuação escolar, como universidade, cursos técnicos e demais cursos de aperfeiçoamento profissional, abrindo caminhos para se considerar diversas carreiras e oportunidades de emprego para pessoas trans* $\mathrm{e}$, também, refletir sobre as possibilidades negadas pela exclusão social. 
Com certeza. Valeu muito, porque, graças ao projeto eu consegui voltar pra escola, então eu vou ter uma formação acadêmica, porque eu quero fazer faculdade quando eu terminar a escola, porque eu estou fazendo curso de hardware e eu pretendo fazer $\mathrm{TI}$, só que pra eu fazer $\mathrm{TI}$, eu preciso de histórico. (...) Depois que eu fizer $\mathrm{TI}$, eu quero fazer Análise de Sistemas (Martinez, 2016)

Então, foi até engraçado, porque como eu moro no Florescer, uma casa de apoio para travestis em situação de rua, e lá tem professor de matemática, tem de português, tem também tipo um reforço lá da escola, que eles oferecem. E o professor meu de matemática tem vinte e oito anos, a mesma idade que eu também tenho ele também tem, eu fico falando, nossa, eu poderia estar exercendo alguma faculdade, ter me formado em alguma coisa. $E$ isso faz, assim, a gente querer lutar, porque se ele conseguiu, eu também vou conseguir. Lógico, porque na vida só basta a gente não ter medo, assim, de enfrentar o mundo, de correr atrás do que a gente quer, ter objetivo na vida, entendeu? Que a gente consegue tudo, indo pelo caminho certo, logicamente, a gente consegue tudo (Xavier, 2016)

Quando perguntados sobre o dia a dia deles na escola, a maioria afirma que o ambiente é agradável. Alguns, como os homens trans, falam da passabilidade117 que parecem ter adquirido e como gostam disso, pois acreditam ter mais respeito dos demais alunos. Comentam, com surpresa, a possibilidade de ir ao banheiro de acordo com o gênero que se identificam, falam da dinâmica de voltar para a escola, andar com caderno de baixo do braço, de sair durante o dia para ir à escola ou aos cursos realizados pelo programa e como isso modificou suas rotinas.

${ }^{117}$ Passabilidade, dentro do movimento Trans*, é um conceito que se refere às pessoas que esteticamente são reconhecidas pelo gênero que se identificam. 
É, pelo menos o banheiro de lá eu consigo usar tranquilo,mas, que nem, tipo, shopping, cinema, eu vou, assim, tipo, eu fico caramba, aí eu olho e falo assim, fica na porta me esperando, eu entro e saio rapidinho. Se eu gritar, você emboca ${ }^{118}$ pra dentro também, me tira de lá de dentro. Se eu gritar, chama o segurança, dá um jeito (Martinez, 2016)

Aí foi aí que eu comecei o TransCidadania, comecei a estudar na escola do Cambuci, no CIEJA, outra escola maravilhosa. Pensa numa escola maravilhosa, de alunos maravilhosos, misto, senhoras, jovens, deficientes, travestis e por aí vai. Mas ninguém ela é ele ou é ela? não, nunca tive isso, nunca passei por isso. Aí eu fui estudando, fui conhecendo as meninas, foi onde veio o Grettas $^{2}$, que é a instituição que nós temos, também, agora (Marques, 2016)

Tendo o foco do programa girado em torno da escolaridade, é comum as pessoas participantes mostraram-se satisfeitas e realizadas com o programa, já que entendem como objetivo cumprido o término da escolaridade e as demais coisas como colaterais do programa.

Essa satisfação fica evidente nas falas, mas, também, nos rostos das pessoas participantes nas cerimônias de formatura realizadas no final de cada ano. Nestas ocasiões pude testemunhar um sentimento de etapa cumprida. Não por acaso, esse sentimento é comum a todos que ingressam na vida escolar e almejam terminar seus estudos básicos, seja para iniciar uma vida acadêmica a partir do ingresso na faculdade, ou para ingressar no mercado de trabalho e ter melhores opções de emprego.

${ }^{118}$ Emboca é uma gíria utilizada para se referir ao processo de entrar em algum lugar. 


\begin{abstract}
Estou terminando a oitava série, eu vou tentar ver se alguma empresa olhe pra gente também como um ser humano e não como aberração, e dê essa oportunidade que a gente precisa, porque muitas travestis, que eu moro no Florescer, numa casa em que vivem trinta travestis em situação de rua, muitas que não conseguiram porque não tiveram vaga no TransCidadania se prostituem e elas choram, elas se deprimem, porque elas não têm oportunidade de emprego. A gente que quer é respeito e um emprego pra sobreviver. Eu acho que isso daí não é pedir demais. É ter uma oportunidade pra mostrar que a gente também é capaz de exercer funções dentro de empresas, só que a gente sobrevivendo com dignidade, porque a gente deita com trinta homens, dez homens na noite, imagina quando a gente acaba, volta pra casa, que cabeça que a gente tem? (Xavier, 2016)
\end{abstract}

\subsubsection{Empregabilidade}

Quanto a Empregabilidade, dou destaque para as falas que mencionam as dificuldades de se conseguir espaço no mercado formal de trabalho, a importância da escolaridade para se cumprir essa etapa da vida e seus objetivos quanto ao tema. Mesmo reconhecendo que este não era o objetivo central ao entrar no programa, as pessoas participantes deixaram claro que essa era uma de suas principais preocupações ao concluírem o ciclo, como substituição do auxílio recebido através do POT.

As pessoas participantes demonstraram estar cientes que a Empregabilidade não é o eixo principal do programa, apesar disso, esse eixo perpassa a fala da maioria delas, normalmente relacionados aos planos e expectativas para o futuro a partir da conclusão dos ciclos no TransCidadania.

Ai os cursos do Pronatec não saíram, não só para o TransCidadania, não saiu pra ninguém. Elas vão pedindo resposta e nós sem coordenação. E paralelo a isso... tem questões de que tá previsto no contrato com as usuárias assinam e que, infelizmente, não saiu. $O$ curso tá dividido em módulos, seis meses, não saiu Pronatec, elas fizeram cursos mais cursos de qualificação profissional não teve, e aí? $\mathrm{O}$ que a gente faz? como a gente trabalha com a angústia dessa usuária de ter voltar pra esquina? não é dela, é minha... é nossa (Aparecida, 2016)

Cansa isso, né? A negação de oportunidade (Marques, 2016) 
Porque eu sempre trabalhei e, tipo, graças a Deus eu tinha, assim, algumas sortes, que eu saía de um e logo depois eu conseguia arrumar outro. Mesmo sendo humilhado, mas eu precisava trabalhar, então eu tinha que passar por tudo isso. Mas eu tinha essa sorte. Hoje eu já não consigo mais. Eu acho que não sei, devido ao tratamento eu acho que eu já devo estar mais diferente, a voz engrossou um pouco, então, tipo, eu já não consigo, muito difícil eu arrumar um emprego. Está muito difícil. (...) Eu precisava trabalhar. Quem que vai conseguir trabalhar se você não fez nem a oitava série? Quem vai te contratar? (Martinez, 2016)

Então assim, eu tenho muito medo, porque e as que entraram agora, em 2016, já não vão completar dois anos. O que vai acontecer com elas, voltar pra rua? O que vai acontecer com os técnicos, com nós, que tivemos a primeira oportunidade da vida? A gente pode achar um telemarketing, a gente pode, mas não é o que nós queremos, não é a nossa luta (Marques, 2016)

A Empregabilidade né e a educação andam de mãos juntas, então um precisa acolher o outro. Mas o que acontece porque as pessoas trans tiveram uma vulnerabilidade muito grande na educação elas perdem a oportunidade. Eles não cumpriram o que eles falaram que era fazer a Empregabilidade dessa população, eu acho que não foi nem $30 \%$ nem $40 \%$ na época da primeira turma ... então eu acho que não cumpriram, foram pouquíssimos. Eu acho assim que tem que dar prioridade para Empregabilidade nem que seja para fazer uma faxina numa coisa porque assim... porque depois que o transcidadania acaba a pessoa volta para Rua como eu voltei né? e ai? (Marfree, 2016)

A dificuldade em conquistar postos no mercado de trabalho formal, no caso das pessoas trans* ${ }^{*}$ não está atrelada somente ao aumento do desemprego no Brasil, mas deve-se à transfobia que essas pessoas sofrem cotidianamente e que as excluem dos processos seletivos, mesmo quando possuem qualificação profissional. No que concerne à inserção da população trans* na esfera do trabalho, a transfobia é o maior desafio a ser superado.

Então. E esse mundo de travesti, transexual, é um mundo sofrido, assim, por causa das pessoas que nos julgam como aberração, entendeu? E não veem a gente como ser humano, veem a gente como aberração, como monstro. Eu acho que não é bem assim, é uma coisa muito, dói. Dói, porque só quem sofre na pele sabe que dói, porque eu já perdi varias oportunidades de emprego por ser travesti. Porque teve, eu fui lá no [...] como auxiliar de limpeza, foi no dia da entrevista vinte e nove pessoas, vinte e sete pessoas passaram, duas não passaram. Engraçado, porque o resto, as que passaram se consideram homem cis e mulher cis e aquelas que não passaram foi eu e uma menina que é homem trans. Então. E sabe que a desculpa que eles inventaram pra não me pegar? Porque eu fumava cigarro. E quem que não fuma hoje em dia? (Xavier, 2016) 
É evidente, entretanto, que o programa thes deu esperanças em relação às oportunidades e possibilidade de melhoria na qualidade de vida. Mesmo enquanto narram a realidade extremamente cruel que vivenciam, todas, sem exceção, demonstram através de suas falas grandes expectativas para o futuro, muitas relacionando com as oportunidades que conseguiram através do programa. Um quadro de positividade para um futuro que, por vezes, é dado como incerto.

Ah, sim, respeito, alegria, dignidade, olhar de cabeça erguida pra qualquer um, sem ter medo, não olhar pra baixo, olhar pra cima e dizer: eu sou ser humano, sou uma travesti, sim, sou digna, sustento uma casa, eu tenho uma mãe, eu tenho um amor e posso ser como qualquer outra pessoa, lutar... (Marques, 2016)

Eu me sinto mais confortável comigo mesmo depois do Programa, porque antes eu era assim, muito, tipo, tudo me assustava, eu não queria chegar em lugar nenhum, tinha medo de não ser respeitado, até mesmo medo de apanhar (Martinez, 2016)

Ajudou, porque assim eu estou me capacitando para amanhã concorrer a uma vaga de emprego, porque não é só concorrer, a gente tem medo do preconceito, isso que é o pior. Porque por mais que seja capacitada, tem pessoas com preconceito que não aceitam travesti na empresa. Então são dois problemas, né (Xavier, 2016)

\subsubsection{Direitos, Cidadania e Conjuntura Política}

Eu fico com uma raiva, que tudo que eu tenho que fazer eu tenho que mostrar documento. Aí quando você puxa o documento está aquele nome lindo, maravilhoso, estampado, assim, no documento. Aí a pessoa fala que o documento não é seu. Ontem quase que eu não voto. "Não, mas esse título não é seu". Dá uma olhadinha aí no RG". "Ah, desculpa". "Eu só quero votar, posso ir?". Ela, "não, vai lá". Ai, que saco. Dá uma raiva quando você vai fazer essas coisas (Martinez, 2016) 
Pra mim foi muito importante por vários motivos assim, mas dentre eles, antes do TransCidadania, antes de eu fazer o curso de direitos humanos - na época do meu tempo de programa existia esse curso para gente, eu não tinha, assim, eu eu pensava que a gente não tinha direito né? Assim, uma vez que a gente é transexual ou travesti no Brasil eu achava que a gente não tinha direitos. Embora, mesmo não sabendo que os tinha eu sempre lutei por isso sabe, eu sempre fui atrás de correr ,sempre corri atrás das coisas que eu achava que era de meu direito e depois que eu fiz, que eu participei do programa e tive certo alguns cursos que para mim foi muito importante no meu desenvolvimento pessoal, como na minha comunidade, não só na minha comunidade onde eu vivo, onde eu moro aqui no Capão Redondo mas também na questão dos meus iguais os homens trans (Medeiros, 2016).

Quando analiso as frases supracitadas das pessoas entrevistadas, percebo cidadania pensando como Coutinho (1999, p.42), ou seja, o resultado de uma luta permanente, majoritariamente das classes sociais populares e mais vulneráveis, nesse caso as pessoas travestis e transexuais, que compreende o programa TransCidadania quando fala em efetivação da cidadania. É a tomada de volta para essa parcela da população dos ditos direitos para todos independente de raça, gênero, religiosidade e orientação sexual, que estão fundamentados nos diversos tratados internacionais promovidos pela ONU como observamos nos capítulos anteriores.

Durante as entrevistas, quando foi abordado questões que tocassem nos pontos de direitos e cidadania, percebi que programa TransCidadania através do curso de direitos humanos, mencionado nos capítulos anteriores, aparentemente conseguiu alcançar seus objetivos quanto a conscientização e politização das pessoas participantes do programa quantos aos seus direitos e deveres quanto cidadãos de direito, mas não apenas isso; Percebi que ao participarem dos cursos as pessoas participantes se sentiam um pouco mais conscientes de si e ainda mais impulsionadas a reivindicarem suas pautas. Ou seja: o curso, aliado a toda estrutura do programa, conseguiu dá ferramentas para que as pessoas participantes se tornassem sujeitos ativos e críticos das suas próprias histórias. 
Porque antes do TransCidadania, a Amanda Marfree era o que? Era mais uma garota de programa, transexual, que tava na rua, se prostituindo, que não sabia ter direitos como cidadão, nem direitos nem deveres, não sabia que no quinto paragrafo da constituição, somos todos iguais perante a lei, né. Não sabia nem que podia entrar numa câmara, que dirá gritar pelos nossos direitos. Então esse programa me tirou, me deu a visão, né, do mundo como um todo (Marfree, 2016).

Embora o oferecimento de apoio jurídico e tratamentos de saúde sejam oferecidos pelo programa, a maioria das pessoas participantes revelaram que já conheciam esses direitos e estavam mobilizadas para obtê-los. Entretanto, elas ressaltam a importância do acompanhamento e auxílio no andamento dos processos, tanto para aquelas que já estavam mobilizadas, mas principalmente para aquelas que ainda não haviam começado incluindo as que não conseguiram ser inseridas no programa e buscaram o apoio em outras instituições como os centros de referência LGBTQIA.

De um modo geral, as pessoas participantes demonstram gratidão ao programa, embora façam questão de pontuar a necessidade de permanência, ampliação e transformação do projeto a fim de garantir sua continuidade independentemente da gestão vigente. Elas expressam incredulidade quanto ao desenvolvimento de políticas públicas voltadas para pessoas trans* no âmbito geral, principalmente por associar o "fazer política" à vontade pessoal dos gestores e não pelo reconhecimento da necessidade dessas políticas para pessoas trans* em específico.

Eu espero que ele continue e que possa continuar ajudando muitas outras pessoas, assim como está me ajudando. Porém eu acho que ele não vai continuar...(Martinez, 2016) 
Nós estamos numa Presidência golpista, estamos num governo que rouba dinheiro de merenda, não valoriza os professores, não valoriza os moradores de bairro, de comunidades, porque a região dele é outra, é Jardins, ele é empresário. E nós, simplesmente, os paulistanos elegeram um outro empresário. Um empresário que vai valorizar também as empresas e vai deixar nós, que somos pessoas mais vulneráveis, jogadas de lado. (...) Agora, um Programa como esse, que existe um leque de... Assistente social, psicólogo, advogado, uma coordenadora, oportunidade de emprego, oportunidade de voltar à escola, visibilidade, curso de Direitos Humanos, curso do Senai, cursos que eles vão buscando parceria e uma bolsa pra ajudar elas a não se empenharem tanto no meio de uma rua pra não perder a escola. Aonde nós vamos encontrar isso novamente? (Marques, 2016)

Mas é muito difícil falar, sinceramente, é muito difícil, porque o único prefeito mesmo que beirou assim meu respeito, que, tipo, meu carinho, foi o Haddad, por enquanto, porque eu não vi nenhum outro. Porque eu já morei em Sorocaba, já morei em outros lugares, não vi nenhum outro parecido, nem parecido, imagina igual, nem parecido. Porque ele, sim, ele abraçou e acolheu, viu a gente com humanidade, nos respeitou, nos deu a oportunidade que a gente precisava (Xavier, 2016)

Esse receio quanto ao futuro do programa demostrando pelas pessoas participantes é perfeitamente compreensível quando observamos os cenários das políticas públicas existentes no Brasil para pessoas Travestis e Transexuais. Muito embora o cenário também tem revelado avanços e conquistas, ele continua desafiador, e as movimentações políticas em torno de eleições mexem com as expectativas sobre o futuro para a população trans*.

Cara eu em choque quando eu vejo essas coisas porque assim a gente luta tanto para nossas garantias a massa da população LGBT mas da população em geral para ter seus direito para que tudo ocorra na medida do possível bem e a gente vê uma informação dessa aí e a gente fica assim sei lá tem dia que eu fico assim eu paro e fico observando algumas situações e o que mais me choca na situação desse Bolsolixo aí Medeiros, 2016).

Se um bolsonaro da vida entrar e tudo vai por água abaixo, ele pode... Nossa... de repente voltar até, Deus me livre, a uma ditadura até coisas piores né? então eu acho que é continuar nesse caminho a pessoa ter consciência no voto, a pessoa também que vai voltar né? ... o que eu fico pensando é uma população LGBT às vezes bota três milhões numa parada e não consegue eleger Um representante LGBT lá" (Marfree, 2016) 
então eu tô bem graças a Deus, eu tô feliz, eu tô trabalhando né. Fiz dois anos na empresa que eu estou agora. Me ajudou o TransCidadania me ajudou porque assim né, fiz os cursos, terminei a escola pela TrasCidadania. Sai um ano antes do projeto né, porque no caso são dois anos mas graças a Deus né, eu consegui me formar no primeiro ano eu consegui um trabalho que é isso que eu tô hoje, e pretendo, mas infelizmente no momento eu não tenho condições de fazer faculdade de assistência social e já era um sonho meu desde que eu morava na rua mas ficou mais forte desde que eu participei do projeto (Medeiros, 2016).

Não pra mim, pra todas elas. Tristes aquelas que souberam usufruir de tudo isso, porque diz o ditado que não se bate duas vezes na mesma porta. Então assim, muitas meninas saíram da rua, muitas conseguiram alugar um quarto-sala, um banheirinho, muitas puderam ter um pouco mais de dignidade, muitas puderam escolher a rua ou o trabalho e o estudo. Então dizer que não é importante, que não foi importante, é uma grande mentira. É importante, principalmente pra quem passou séculos e décadas, e décadas sem ser vista, achando que o único lugar da gente é rua, camisinha e gel (Marques, 2016)

Apesar das contradições como a questão da empregabilidade, as questões que o programa parece ter dado conta, como a escolaridade, a assistência psicossocial e o auxílio financeiro tiveram uma grande importância na visão das beneficiárias, que concluem que a experiência foi satisfatória, principalmente ao comparar com o cenário anterior ao TransCidadania, quando as políticas públicas voltadas para elas eram praticamente nulas. 


\section{CONSIDERAÇÕES FINAIS}

Para analisar os resultados do Programa usamos aqui algumas ferramentas teóricas importantes, tais como a aplicação da descrição da teoria dos Ciclos de Políticas Públicas de Mainardes (2001) descrito no item 4.4.1 deste trabalho; o balanço oficial de 2 anos de programa e as entrevistas com membros e as pessoas participantes do programa.

\subsection{Transcidadadia e o Ciclo de Políticas Públicas de Ball}

A seguir irei analisar os ciclos de políticas públicas de acordo com os passos realizados pelo programa TransCidadania.

\subsubsection{Contexto de Influência: discussão, contexto e demandas}

Quando iniciei este trabalho em 2015, o debate das políticas públicas para Travestis e Transexuais no Brasil estava visivelmente na agenda política do momento, e este era o contexto em que o programa TransCidadania nasce em São Paulo.

Muito se falava da necessidade e urgência de programas específicos para atender essa parcela da população, ONG's como a TGEU divulgava o balanço do quadro de violência a pessoas trans* no mundo.

O movimento LGBTQIA debatia as consequências da ampliação da discussão, bem como as pautas do movimento com a lei de identidade de gênero, o uso no nome social, a transexualidade permanecer categorizada como doença no CID e tantas outras que permeavam o debate sobre a Saúde, Empregabilidade, Educação e Cidadania das pessoas trans*. 
Esta etapa pode ser interpretada, de acordo com o Ciclo de Políticas de Ball (2001)119 como o Contexto de Influência: onde as partes interessadas disputam as definições e propósitos da política, e tem início sua elaboração. Percebe-se nitidamente os envolvimentos de grupos sociais que influenciam o governo, mas não são eles que determinam diretamente a política (Mainardes 2006, p.51).

\subsubsection{Contexto produção de texto:}

Aqui ressaltamos a produção do decreto de instalação do programa, as diretivas para atendimento nos setores do programa, o balanço geral e outros matérias que deram visibilidade ao programa e nos deixaram a par de seu andamento.

\subsubsection{Contexto de Prática: Lançamento, escolha dos atores.}

A implementação do programa TransCidadania e seus primeiros dias de vida ainda em 2015, foi dada após a escolha de uma entidade da sociedade civil, uma instituição chamada Koinonia Presença Ecumênica e Serviços, que assumiu a responsabilidade pela execução de atividades educativas e monitoramento das ações do programa de acordo com as demandas da fase anterior a respeito dos seguintes temas: Educação, Empregabilidade, Cidadania. Desta forma, no dia 25 de janeiro de 2015 foi implementado o programa, visando estabelecer um sistema de política pública transparente e transversal.

A fase de implementação de um programa como o TransCidadania é o momento onde os atores do processo colocam a política em andamento, e é também onde se fazem as interpretações e as consequências são avaliadas. Esta fase é associada ao Contexto de Prática do Ciclo de política de Ball (2001), que de acordo com Mainardes (2006, p.53) "é o lugar onde a política é sujeita à interpretação e recriação e onde a política produz efeitos e consequências que podem representar mudanças e transformações significativas na política original". 
7.1.4 Contexto de Estratégia Política: avaliação, criação de demandas, recriação

Este de constante desenvolvimento acompanha o programa desde seu primeiro ciclo, tornando o TransCidadania uma política viva e dialogável, até mesmo com a própria conjuntura do movimento Trans ${ }^{*}$, dos fatos políticos que influenciam todo o cenário do movimento LGBTQIA, tornando o a construção do modelo ligada ao contexto real do dia a dia, aos aprendizados com a experiência que o programa trazia.

Essa percepção sobre novos obstáculos no decorrer do dia a dia do programa, e as iniciativas para lidar com os desafios que vão surgindo, também estão previstas no ciclo de política de Ball (2001); Para esse momento ele dá o nome de Contexto de Estratégia Política. Mainardes (2006, p.55) afirma que "este contexto envolve a identificação de um conjunto de atividades sociais e políticas que seriam necessárias para lidar com os problemas identificados, principalmente as desigualdades criadas ou reproduzidas pela política investigada".

7.1.5 Contexto de Resultados: Estatísticas, mas principalmente efeitos e avaliação dos participantes

No caso do programa TransCidadania analiso ao mensurar os resultados das entrevistas com as pessoas participantes que esta mostrou-se ser a forma mais adequada de avaliação, pois a eficácia e eficiência do programa estão além dos números apresentados em balanço. Ela perpassa também pelas conquistas subjetivas de cada pessoa participante do programa conseguindo superar obstáculos, ou medos. A constatação dos efeitos é necessária para a avaliação da sua eficácia e para a manutenção e/ou correção, aperfeiçoamento ou replanejamento, o que segundo Mainardes (2006, p.54), no Ciclo de Políticas Públicas seriam chamados de contextos de resultados/efeitos. São estes resultados e efeitos são o que busquei analisar nesses mais de dois anos de pesquisa. 


\subsection{Balanço geral dos dois anos}

Segundo o balanço geral publicado em 2016120, o Transcidadania como uma política pública social cumpre um papel importante na promoção de direitos e cidadania, tal como prevê o seu decreto de criação, possibilitando a inserção de centenas de pessoas travestis e transexuais no âmbito escolar, podendo com isso concluir seus estudos e almejar algumas possibilidades que a educação formal pode garantir tal como o conhecimento de maneira geral, a socialização e interação escolar, e uma possibilidade a mais de disputar uma vaga no mercado de trabalho formal, caso tais pessoas assim o queiram.

Como um programa de política focal, ou seja, especializada em uma parcela específica da sociedade, as possibilidade de acertos são maiores, pois de acordo com os relatos colhidos, o programa consegue garantir um ambiente de segurança e confiança para as pessoas participantes que se sentem à vontade de estimuladas a seguir com o curso até o final, garantindo além de auxílio financeiro, assistência social, psicológica e pedagógica, com uma disponibilidade maior caso procurassem esses serviços individualmente.

Apesar de seu alcance ser quantitativamente reduzido se comparado com o número de pessoas trans* da cidade de São Paulo, ou mesmo a lista de espera para uma vaga no programa, o que ressalta ainda mais a urgência de ampliação das vagas , o TransCidadania tem se consolidado no espaço que existe na política pública como um programa que era uma demanda urgente. E demonstra que sua ampliação e replicação em outros estados e cidades não só é possível, como necessária

O programa TransCidadania demonstra ter fragilidades quanto a ampliação e execução de seus objetivos, mas através de seus resultados mostra também sua potência como a efetivação cidadania, direitos e educação. Pois ao se constituir como uma política se levanta a pauta e impulsiona a reflexão, outros grupos em diversos locais começam a exigir e lutar por políticas se não iguais, semelhantes para si.

\footnotetext{
${ }^{120}$ Balanço Programa TransCidadania. Secretaria Municipal de Direitos Humanos e Cidadania. Brasil, São Paulo. (2016).
} 
Por exemplo, apesar de relatado ao longo do trabalho que a decisão do número de beneficiárias para atendimento era uma decisão política de primeiro momento, para garantir a implementação, três anos se passaram do lançamento do programa e pouco se fez em relação ao aumento da capacidade de atendimento de pessoas, ou, ainda não se efetuou uma pesquisa que apontasse qual seria o número ideal de vagas dada a estrutura do programa.

O programa nos dois primeiros anos de vida, também encontrou dificuldades para implementar diretrizes do seu escopo que são de extrema importância para garantir a autonomia financeira das beneficiárias. A questão da Empregabilidade e da preparação técnica foram ineficazes, a dos estágios também, e poderia ser boas estratégias para garantir que as beneficiárias tivessem para além do período do programa uma fonte estável de subsistência.

Apesar disso, é impossível negar o impacto que o programa teve nas vidas de Luciano, Amanda, Aline, Felipe, Milena e tantas outras pessoas que passaram pelo programa e se reconheceram a partir de então como pessoas cidadãs de direito, e analisar a eficácia da política por essas narrativas também. Pois como observa Mainardes (2006, p. 54) é mais sensato pensar a política pública em termos de efeitos ao invés de resultados, pois dessa forma não se centra a atenção em simples métricas de resultados, e sim dirige o olhar para questões de justiça, igualdade e liberdade individual.

\subsection{Relatos e entrevistas}

Os relatos das entrevistadas demonstraram que o programa se tornou um ponto de procura por oportunidade para pessoas travestis e transexuais, que podem estar ou não dentro dos critérios do programa. Não atendendo os critérios de aceitação, algumas permanecem no grupo de vulnerabilidade social, e observo que o programa TransCidadania poderia trabalhar dentro da transversalidade com parcerias com centros de referência e de educação a fim de buscar ter ações de Empregabilidade para pessoa que não conseguem ingressar no programa TransCidadania. 


\subsection{Novas Questões e avaliação geral}

Próximo de completar quatro anos em janeiro de 2019, já passaram pelo TransCidadania mais de 400 pessoas, e diversas dúvidas e questionamentos vão aparecendo a respeito das possiblidades e oportunidades das pessoas participantes após o programa.

Diversas questões ainda podem ser investigadas também ainda sobre o próprio programa, como por exemplo a questão da mulher negra travesti e transexual, que ocupa grande porcentagem das participantes? Seria isso uma questão de acaso, ou teria essas pessoas questões em comum que as ligassem em grupo com pautas e dores especificas? Minha sugestão para quem se interessar em navegar nesse mar profundo é que são sim as travestis e mulheres trans negras um grupo social marcados ainda mais pelo preconceito e negação de oportunidades por conta da misoginia, transfobia e do racismo.

Ou ainda, investigar os novos rumos do programa TransCidadania pós 2016, ou seja, pós gestão Haddad, responsável pelos dois primeiros anos de vida do programa, tempo que se deu esse trabalho. Sabe-se que atualmente o TransCidadania mudou o foco do seu objetivo, centrando a questão da empregabilidade, tomou diversas decisões administrativas com a extinção do grupo multidisciplinar, deu a responsabilidade de gestão de cada centro do TransCidadania (Zona Leste, Zona Oeste, Zona Sul e Zona Norte) para algumas ONG's gerenciarem, formando assim administrações descentralizadas.

Também se sabe pelas entrevistas que há uma preocupação real das pessoas atendidas pelo programa com a nova conjuntura política. A eleição em 2018 de um presidente com pautas assumidamente anti-minorias pode dificultar enormemente a permanência dos investimentos e da estrutura para a manutenção do programa. Outra preocupação geral das entrevistadas é com o aumento da violência, do preconceito e do acirramento das condições de trabalho precárias para pessoas trans* ou travestis no país. 
O tempo no programa também é uma questão com que as próximas gestões terão que lidar. Como pude observar anteriormente, o TransCidadania está atrelado a um programa chamado POT que institui por lei o tempo de permanência de cada beneficiária, não dando possibilidade que as mesma possa usufruir dos benefício para além de 2 anos, o que é insuficiente, quando comparamos as necessidades e o déficit escolar destas, e os anos de violência, exclusão e negação de oportunidade para essa população.

O TransCidadania seria desta forma uma política setorial exemplar, por conseguir de maneira multidimensional apoiar um segmento discriminado, frequentemente vítima do preconceito, da violência e da exclusão social, portanto altamente vulnerável, proporcionando condições para que essas pessoas tenham perspectivas de inserir-se de maneira digna na sociedade e ter um futuro mais favorável para que vivam com segurança e que desenvolvam suas aspirações pessoais e profissionais, as capacitando para serem ainda mais agentes ativas da mudança cultural, na própria política pública e a partir dela, nas pessoas que direta ou indiretamente participam do TransCidadania e na sociedade que vivem.

Contudo, o programa TransCidadania não é ferramenta de mudança só para a vida das pessoas participantes, mas também é ferramenta de impacto e mudança para aqueles que ao se aproximarem permitem-se mudar o olhar estigmatizado quanto às pessoas travestis e transexuais. Um programa ainda cheio de limites e enormes desafios, mas também um programa que concretamente já tem sido mais que do que rua, camisinha e gel. 


\section{REFERÊNCIAS}

Antunes, P. P. S. (2013) Travestis envelhecem? São Paulo, Brasil: Annablume, 258 pp.

Aparecida, C. (2016) Entrevista cedida a Michelle Borges Miranda, 04 de outubro de 2016.

Balanço Programa TransCidadania. Secretaria Municipal de Direitos Humanos e Cidadania. Brasil, São Paulo. (2016)

Ball, S. (2001) Diretrizes Políticas globais e Relações Políticas Locais em Educação. Currículo sem fronteiras, 1(2): 99-116.

Ball, S. (2002) Reformar escolas/reformar professores e os terrores da performatividade. Revista Portuguesa de Educação, 15(2): 3-23.

Bagagli, B. A Travestilidade como Resistência à Lógica Diagnóstica. Texto de blog, 2015. Disponível em: https://transfeminismo.com/a-travestilidade-comoresistencia-a-logica-diagnostica/.Acessado em: 29/04/2015.

Benedetti, M.(2005) Toda Feita: corpo e o gênero das travestis. Rio de Janeiro: Garamond.

Benevides, M. V. de M. (1994) Cidadania e democracia. Lua Nova, 33: 5-16.

Bento, B. (2006) A (re)invenção do corpo: sexualidade e gênero na experiência transexual. Rio de Janeiro: Garamond/Clam.

Bento, B. (2008) O que é transexualidade. São Paulo: Brasiliense.

Bento, B. (2011) Na escola se aprende que a diferença faz a diferença. Revista Estudos Feministas, 19(2): 549-559.

Bento, B. (2014) Nome social para pessoas trans: cidadania precária e gambiarra legal. Contemporânea - Revista de Sociologia da UFSCar, São Carlos, 4(1): 165182.

Bento, B. \& Pelúcio, L. (2012) Despatologização do gênero: a politização das identidades abjetas. Revista Estudos Feministas, 20: 569-581.

Bibeau, G. (1996) - Séminaire sur l'Interdisciplinarité et l'Application - Description. Département d'Anthropologic, Université de Montreal, mimeo

Bitencourt, S. M. (2013) Contribuição de Teóricas Feministas para os Estudos de gênero. Revista Ártemis, 16 (1): 178-185. 
Bueno, S. F. (2015) Da teoria crítica ao pós-estruturalismo: breves apontamentos para uma possível confrontação entre Adorno e Deleuze. Educar em Revista, 56: 149-161.

Butler, J. (2003) Problemas de gênero. Feminismo e subversão da identidade. Rio de Janeiro: Civilização Brasileira.

Butler, J. (2005) Cuerpos que importan: sobre los límites materiales y discursivos del "sexo". Buenos Aires: Paidós, p. 17-49 e 179-203.

Carrara, S. (2010) Políticas e direitos sexuais no Brasil contemporâneo. Bagóas, 4(5): 131-147.

Carrara, S., \& Vianna, A. R. B. (2006). "Tá lá o corpo estendido no chão...": a violência letal contra travestis no município do Rio de Janeiro. Physis: Revista de Saúde Coletiva, 16(2), 233-249.

Carvalho, J. M. (2002) Cidadania no Brasil: o longo caminho. Rio de Janeiro: Civilização Brasileira.

Carvalho, M. \& Carrara, S. (2013) Em direito a um futuro trans?: contribuição para a história do movimento de travestis e transexuais no Brasil. Sexualidad, Salud y Sociedad (Rio de Janeiro), 14: 319-351.

Carvalho, M. F. de L. (2011) Que mulher é essa?: identidade, política e saúde no movimento de travestis e transexuais. Dissertação de Mestrado, Rio de Janeiro: Universidade do Estado do Rio de Janeiro.

Chaui, M. (1984) Cultura e democracia. São Paulo, Editora Moderna

Concilio I. L., Amaral, M. Silveira, P. M. (Orgs.) Transcidadania: Práticas e trajetórias de um Programa Transformador. Koinonia \& Prefeitura de São Paulo: São Paulo, 2017.

Conklin, J. (2005) Dialogue mapping: Building shared understanding of wicked problems. John Wiley \& Sons, Inc..

Correia, M. C. B. (1999) A observação participante enquanto técnica de investigação. Pensar enfermagem, 13(2) 30-36.

Coutinho, C. N. (1999) Cidadania e Modernidade. Perspectivas (UNESP), 22: 4159.

Cruz, E. F. (2011) Banheiros, travestis, relações de gênero e diferenças no cotidiano da escola. Revista Psicologia Política, 11(21): 73-90.

Carvalho, M. E. P.; Andrade, F. C. B. \& Junqueira, R. D. (2009) Gênero e diversidade sexual: um glossário. João Pessoa: Ed. Universitária UFPB. 
Decreto, $N^{\circ}$ 44.484, de 10 de março de $2004.451^{\circ}$ da fundação de São Paulo.

Publicado na Secretaria do Governo Municipal. São Paulo. (2004)

Decreto, $N^{\circ}$ 55.874, de 29 de Janeiro de 2015. $462^{\circ}$ da fundação de São Paulo. Publicado na Secretaria do Governo Municipal. São Paulo, (2015).

2006/2006/lei/l11340.htm. Acessada em 23 de julho de 2018

DYE, T. D. (1984) Understanding Public Policy. Englewood Cliffs, N.J.: PrenticeHall.

Facchini, R. (2003) Movimento homossexual no Brasil: recompondo um histórico.

Cadernos Arquivo Edgard Leuenroth, 10(18/19): 79-123.

Facchini, R. (2011) Conselho Regional de Psicologia da $6^{\text {a }}$ Região (org).

Psicologia e diversidade sexual. / Conselho Regional de Psicologia da 6 a Região São Paulo: CRPSP,. 92f.; 23cm. (Caderno Temático 11). Bibliografia ISBN: 978-8560405-16-9

Fausto-Sterling, A. (2002) Dualismos em duelo. Cadernos Pagu, 17-18: 9-79.

Figari, C. (2007) @s “outr@s” cariocas: interpelações, experiências e identidades homoeróticas no Rio de Janeiro: séculos XVII ao XX. Belo Horizonte: Editora UFMG; Rio de Janeiro: IUPERJ.

Filho, A. T. (2005) Uma questão de gênero: onde o masculino e o feminino se cruzam. Cadernos Pagu, 24: 127-152.

Foucault, M., \& Marquet Montiel, A. (1989). El poder: cuatro conferencias.

Foucault, M. (1988) História da Sexualidade: A Vontade de Saber. Rio de Janeiro: Graal.

Foucault, M. (2010) Os anormais. Curso no Collège de France. São Paulo: Editora WMF, Martins Fontes.

Foucault, M. (2013) Vigiar e punir: nascimento das prisões. Rio de Janeiro: Editora Vozes.

Gadotti, M. (1995) História das ideias pedagógicas. São Paulo: Ática.

Green, J. N. (2000) Além do carnaval. A homossexualidade masculina no Brasil do século XX. São Paulo: Editora UNESP.

Grossi, M. P. \& Graupe, M. E. (2014) Desafios no processo de implementação do curso gênero e diversidade na escola (GDE) no estado de Santa Catarina. Poiésis Revista do Programa de Pós-Graduação em Educação (Unisul), 8(13): 104-125.

Guareschi, N. et al. (2004) Problematizando as práticas psicológicas no modo de entender a violência. In: Strey, M. N.; Azambuja, M. P. R.; Jaeger, F. P. (Org.). 
Violência, gênero e políticas públicas (pp 177-193). Porto Alegre: EDIPUCRS.

Guedes, M. E. F. (1995) Gênero, o que é isso? Psicologia: Ciência e Profissão, 15. (1-3): 4-11.

Jesús, B. M. (2013) Campanha para a despatologização da transexualidade no Brasil: seu discursos e suas dinâmicas. Dissertação (Mestrado em Sociologia) Programa de Pós-Graduação em Sociologia, Universidade Federal de Goiás, Goiânia.

Jesus, J. G. (2012) Orientações sobre a população transgênero: conceitos e termos. Brasília: 24p. Disponível nos seguintes endereços:

http://pt.scribd.com/doc/87846526/Orientacoes-sobre-Identidade-de-Genero$\underline{\text { Conceitos-e-Termos }}$

Jesus, J. G. (2014) Interlocuções teóricas do pensamento transfeminista. In: Transfeminismo: teorias e práticas. Rio de Janeiro: Metanoia, 2014. 206 p.

Kaas, H.. (2012) Introdução ao transfeminismo. Transfeminismo: feminismo interseccional relacionado às questões Trans ${ }^{*}$,. Disponível em:

https://transfeminismo.com/introducao-ao-transfeminismo/ Acesso em: 11 de Agosto de 2015.

Knauth, D. R. (2000) Pesquisa Qualitativa em Saúde. Porto Alegre: Tomo Editorial,. v. 01. 136pp.

Koyama, E. (2001) The transfeminist manifesto. Feminism.org, 15 pp.

Kulick, D. (1998) Travestis, sex, gender and culture, among brazilian transgendered prostitutes. Chicago: The University of Chicago Press.

Lapa, N. (2013) O preconceito contra transexuais no mercado de trabalho. In: Carta Capital.

Lauretis, T. D. (1994). A tecnologia do gênero. Tendências e impasses: o feminismo como crítica da cultura. Rio de Janeiro: Rocco, 132, 123-132.

Larrat, S. (2016) Entrevista cedida a Michelle Borges Miranda, 04 de outubro de.2016.

Lei Maria da Penha (2006). Disponível em http://www.planalto.gov.br/ccivil_03/_ato2004-

Leite Júnior, J. (2008) Nossos corpos também mudam: sexo, gênero, e a invenção das categorias "travesti" e "transexual" no discurso cientifico.. Tese (Doutorado). São Paulo: PUC-SP.

Lynn, L. E. (1980) Designing Public Policy: A Casebook on the Role of Policy 
Analysis. Santa Monica, Calif.: Goodyear.

Longo, F. (2015) Movimento: Produção de discurso LGBT - Parte 4. . Acesso em 28 de julho de 2

Lüdke, M. \& André, M. E. D. A. (1986) Pesquisa em educação: abordagens qualitativas. São Paulo, EPU.

Maia, M. C. (2012) História do Direito no Brasil - os direitos humanos fundamentais nas Constituições Brasileiras. Revista Juris FIB, 3: 267-283.

Mainardes, J. \& Marcondes, M. I. (2009) Entrevista com Stephen J. Ball: um diálogo sobre justiça social, pesquisa e política educacional. Educação e Sociedade, 30(106): 303-318.

Mainardes, J. (2006) Abordagem do ciclo de políticas: uma contribuição para a análise de políticas educacionais. Educação e Sociedade, 27(94): 47-69.

Manzini, E. J. (2003) Considerações sobre a elaboração de roteiro para entrevista semi-estruturada. In: Marquezine: M. C.; Almeida, M. A. \& Omote; S. (Orgs.)

Colóquios sobre pesquisa em Educação Especial (pp. 11-25). Londrina:eduel.

Marques, A. (2016) Entrevista cedida a Michelle Borges Miranda, 05 de outubro de 2016. [A entrevista encontra-se transcrita no apêndice $B$ desta dissertação].

Marshall, T.H. (1967) Cidadania, Classe Social e Status. Rio de Janeiro: Zahar Editores.

Martinez, F. (2016) Entrevista cedida a Michelle Borges Miranda, 05 de outubro de 2016. [A entrevista encontra-se transcrita no apêndice B desta dissertação].

Matos, M. (2010) Movimento e teoria feminista: é possível reconstruir a teoria feminista a partir do Sul global? Revista de Sociologia e Política, 18(36): 67-92.

MEAD, L. M. (1995) “Public Policy: Vision, Potential, Limits", Policy Currents, Fevereiro: $1-4$.

Mello, L.; Brito, W. \& Maroja, D. (2012 b) Políticas públicas para a população LGBT no Brasil: notas sobre alcances e possibilidades. Cadernos Pagu, 39: 403-429.

Mello, L.; de Avelar, R. B. \& Brito, W. (2014) Políticas públicas de segurança para a população LGBT no Brasil. Revista Estudos Feministas, 22: 297-320.

Mello, L.; de Avelar, R. B. \& Maroja, D. (2012 a) Por onde andam as políticas públicas para a população LGBT no Brasil. Sociedade e Estado, 27: 289-312.

Mello, L.; Freitas, F.; Pedrosa, C. \& Brito, W. (2012 c) Para além de um kit antihomofobia: políticas públicas de educação para a população LGBT no Brasil.

Bagoas : Revista de Estudos Gays, 7: 99-122. 
Mello, L.; Irineu, B. A.; Froemming, C. N. \& Kabral, V. R. (2013) Políticas públicas de trabalho, assistência social e previdência social para a população LGBT no Brasil: sobre desejos, realizações e impasses. Revista de Ciências Sociais, 44: 132-160.

Menezes, E. T. \& dos Santos, T. H. (2001) Verbete transversalidade. In: Dicionário Interativo da Educação Brasileira. Educabrasil. São Paulo: Midiamix. Disponível em: http://www.educabrasil.com.br/transversalidade/

Miskolci, R. (2009) A Teoria Queer e a Sociologia: o desafio de uma analítica da normalização. In: Sociologias, $\mathbf{n}^{\circ} 21$ (pp. 150-182). Porto Alegre: UFRGS.

Moreira R. (Produtor) \& Moreira R.(Diretor) (1988) Temporada de caça, Documentário (24 min.): son. color. São Paulo, Brasil. Produção independente

Narvaz, M. G. \& Koller, S. H. (2006) Metodologias feministas e estudos de gênero: articulando pesquisa, clínica e política. Psicologia em Estudo, 11(3): 647-654.

Nicholson, L. (2000) Interpretando o Gênero. Revista Estudos Feministas, 8(2): 941.

Nolasco, A. (2016) Entrevista cedida a Michelle Borges Miranda, 04 de outubro de 2016.

Nota Conceitual do Programa TransCidadania. Secretaria Municipal de Direitos Humanos e Cidadania, Brasil, São Paulo. (2014).

Okada, Alexandra (2014). Mapas do conhecimento com recursos educacionais abertos aplicados à coaprendizagem baseada em coinvestigação. In: Torres, Patrícia ed. Complexidade : Redes e Conexões na Produção do Conhecimento. Curitiba:: SENAR - PR, pp. 213-237.

Oliveira, G. (2016) Entrevista cedida a Michelle Borges Miranda, 04 de outubro de 2016.

Organização das Nações Unidas (1948) Declaração Universal dos Direitos Humanos.

Organização das Nações Unidas (1966) Pacto Internacional dos Direitos Civis e Políticos.

Organização das Nações Unidas (2013) Nascidos livres e Iguais: Orientação sexual e Identidade de Gênero no regime Internacional dos Direitos Humanos. Brasília.

Paiva, A. C. S. \& Mello, L. (2013) Políticas de gênero e sexualidade: pensando a cidadania e os direitos humanos de lésbicas, gays, bissexuais, travestis e transexuais (Apresentação de dossiê). Revista de Ciências Sociais, 44: 7-9.

Pastorini, A. (1997)Quem mexe os fios das políticas sociais? Avanços e limites da 
categoria "concessão-conquista". Serviço Social \& Sociedade, 53: 80-101.

Pedro, J. M. (2005) Traduzindo o debate: o uso da categoria gênero na pesquisa histórica. História, 24(1): 77-98.

Pelúcio, L. (2007) "Mona, eu me cuido" - Gênero, Saúde e Corporalidade entre Travestis que se Prostituem. In: Seminário Homofobia, Identidades e Cidadania LGBTTT, Florianópólis. Boletim Eletrônico CLAM.

Pelúcio, L. (2009) Abjeção e desejo: uma etnografia travesti sobre o modelo preventivo de aids. São Paulo: Annablume; Fapesp.

Petry, A. R. \& Meyer D. E. E. (2011) Transexualidade e heteronormatividade: algumas questões para a pesquisa. Textos \& Contextos, 10(1): 193-198.

Petry, A. R. \& Meyer D. E. E. (2011) Transexualidade e heteronormatividade: algumas questões para a pesquisa. Textos \& Contextos, 10(1): 193-198.

Piana, M. C. (2009) A construção do perfil do assistente social no cenário educacional. São Paulo: Editora UNESP; São Paulo: Cultura Acadêmica, 233 pp.

Pimentel, A. (2001) O método da análise documental: seu uso numa pesquisa histórica. Cadernos de Pesquisa, 114: 179-195.

Plano Nacional de Promoção da Cidadania e Direitos Humanos de LGBT. Brasília, DF: SEDH. (2009) Disponível em: http://www.arco-iris.org.br/wpcontent/uploads/2010/07/planolgbt.pdf

Programa Nacional de Direitos Humanos - PNDH-3: ano de 2012. Brasília, DF: SDH, Disponível em: http://www.sdh.gov.br/assuntos/direito-paratodos/programas/programa-nacional-de- Brasil (2012).

Relatório de Monitoramento das Ações do Plano Nacional de Promoção da Cidadania e Direitos Humanos de Lésbicas, Gays, Bissexuais, Travestis e Transexuais (PNPCDH-LGBT). Brasília: SEDH, (2010)

Relatório de violência homofóbica no ano de 2012. Brasília, DF: Gabinete de República, 2012. Disponível em: http://www.sdh.gov.br/assuntos/lgbt/pdf/relatorioviolencia-homofobica-ano-2012, Brasil (2012)

Relatório sobre violência homofóbica no Brasil: ano de 2011. Brasília, DF: SDH, Disponível em: http://www.sdh.gov.br/assuntos/lgbt/pdf/relatorio-violencia-homofobica-ano2011, Brasil (2011)

Revisão de Bourdieu, Pierre (2012), Sur l'État. Cours au Collège de France (19891992). Paris: Raisons d’Agir/Seuil, 672 pp.

Rua, M. G. (1998) Análise de Política Públicas: Conceitos Básicos. In: Rua M. G. \& Carvalho, M. (Org.). O Estudo da Política: Tópicos Selecionados. Brasília: Paralelo 15. 
Rubin, G. (1986) El tráfico de mujeres: Notas sobre la "economía política" del sexo". Nueva antropología, 8(30).

Rubin, G. (1993). Pensando sobre sexo: notas para uma teoria radical da política da sexualidade (tradução em português e de circulação restrita). The lesbian and gay studies reader. Londres: Routledge.

Sampaio, L. L. P., \& Coelho, M. T. A. D. (2013). A transexualidade na atualidade: discurso científico, político e histórias de vida. III Seminário Internacional Enlaçando Sexualidades, Salvador, Bahia, Brasil.

Santos, A. R. (2000) Metodologia Científica: a construção do conhecimento. Rio de Janeiro: DP\&A.

Santos, B. de S. (2007) Renovar a teoria crítica e reinventar a emancipação social. São Paulo: Boitempo Editorial.

Santos, L. L. de C. P. (2003) Bernstein e o campo educacional: relevância, influências e incompreensões. Cadernos de Pesquisa, São Paulo, 120: 15-49.

SCOTT, J. (1990). Gênero: uma categoria útil para análise histórica. Tradução: Christiane Rufino Dabat e Maria Betânia Ávila.

Scott, J. W. (1994) Prefácio a gender and politics of history. Cadernos Pagu, 3:1127.

Scott, J. W. (1995) “Gênero: uma categoria útil de análise histórica”. Educação \& Realidade. 20(2): 71-99.

Secretaria Especial de Direitos Humanos. Anais da Conferência Nacional de Gays, Lésbicas, Bissexuais, Travestis e Transexuais (GLBT). Brasília: SEDH. (2008)

Shiroma, E. O; Campos, R. F. \& Garcia, R. M. C. (2005) Decifrar textos para compreender a política: subsídios teórico-metodológicos para análise de documentos. Florianópolis: Perspectiva,

Silva, C. C. L. (2016) Da luta pela vida à busca pela cidadania: $\mathbf{O}$ ativismo político de travestis e transexuais na cidade de Maceió-AL. Dissertação de mestrado apresentada como requisito parcial para obtenção do título de Mestra, ao Programa de Pós Graduação em Psicologia, da Universidade Federal de Alagoas. $145 f$.

Soares, M. L. Q. (2008) Teoria do Estado: novos paradigmas em face da globalização. São Paulo: Editora Atlas, 201pp.

Souza, C. (2006) Políticas públicas: uma revisão da literatura. Sociologias, 16 : 20-45. 
Triviños, A. N. S. (1987) Introdução à pesquisa em ciências sociais: a pesquisa qualitativa em educação. São Paulo: Atlas.

Valladares, L. (2007) Os dez mandamentos da observação participante. Revista Brasileira de Ciências Sociais, 22(63): 153-155.

Vance, C. S. (1995) A antropologia redescobre a sexualidade: um comentário teórico. Physis, 5(1): 7-32.

Veiga-Neto, A (2001) "Incluir para excluir" in Larrosa J. \& Skliar C. (org.). Habitantes de Babel: políticas e poéticas da diferença (pp.105-118). Belo Horizonte, Autêntica.

Vianna, C. P. (2012) Gênero, sexualidade e políticas públicas de educação: um diálogo com a produção acadêmica. Pró-Posições, 23: 253-278.

Vianna, C. P. (2015) O movimento LGBT e as políticas de educação de gênero e diversidade sexual: perdas, ganhos e desafios. Educação e Pesquisa - Revista da Faculdade de Educação da USP, 41: 791-806.

Vianna, C. P. \& Cavaleiro, M. C. (2012) Políticas Públicas de Educação e Diversidade: gênero e (homo) sexualidades. Gênero, 12: 27-45.

Vianna, C. P. \& Unbehaum, S. (2004) O gênero nas políticas públicas de educação no Brasil: 1988-2002. Cadernos de Pesquisa, 34: 77-104.

Vianna, C. P. \& Unbehaum, S. (2006) Gênero na educação básica: quem se importa? uma análise de documentos de políticas públicas no Brasil. Educação \& Sociedade, 28: 231-258.

Víctora, C. G.; Knauth, D. R. \& Hassen, M. de N. A. (2000) Pesquisa Qualitativa em Saúde: Uma introdução ao tema. Porto Alegre: Tomo Editorial.

Wanzeller, M. (2016) Entrevista cedida a Michelle Borges Miranda, 04 de outubro de 2016. [A entrevista encontra-se transcrita no apêndice B desta dissertação].

Whyte, W. F. (2005) Sociedade de esquina: a estrutura social de uma área urbana pobre e degradada. Tradução de Maria Lucia de Oliveira. Rio de Janeiro, Jorge Zahar. 390 páginas.

Xavier, C. (2016). Entrevista cedida a Michelle Borges Miranda, 05 de outubro de 2016. [A entrevista encontra-se transcrita no apêndice $B$ desta dissertação].

Zanelli, J. C. Silva N. (1996) Programa de Preparação para Aposentadoria. [S.I.]: Insular. 


\section{APÊNDICES}

\section{APÊNDICE A: LINKS UTEIS}

Anais da $2^{\text {a }}$ Conferência Nacional de Políticas Públicas e Direitos Humanos para LGBT (2011). Disponível em: <http://www.abglt.org.br/docs/ANAIS-LGBT-2011_final.pdf>

Deliberação Conselho Municipal de Educação (CME)/2015. Inclusão e uso de nome social de travestis e transexuais nos registros escolares das unidades educacionais no Sistema Municiapl de Ensino. Disponível em: $<\mathrm{http}: / / \mathrm{www}$.sinpeem.com.br/lermais_materias.php?cd_materias=8402\&friurl=_-DeliberacaoCME-no-082015-DOC-de-29012015-paginas-08-e-09-_>

Deliberação Conselho Estadual de Educação (CEE) No 125/2014. Inclusão de nome social nos registros escolares das instituições públicas e privadas no Sistema de Ensino do Estado de São Paulo e dá outras providencias correlatas. Disponível em:

<https://www.defensoria.sp.def.br/dpesp/repositorio/39/Deliberacao_CEE_125_2014.pdf>

Decreto $N^{\circ}$ 8.727, de 28 de abril de 2016. Dispõe sobre o uso do nome social e o reconhecimento da identidade de gênero de pessoas travestis ou transexuais no âmbito da administração pública federal direta, autárquica e fundacional. Disponível em: <http://www.planalto.gov.br/ccivil 03/ ato2015-2018/2016/decreto/D8727.htm>

Manifesto pela despatologização das identidades Trans pelo Conselho Regional de Psicologia - São Paulo (CRP-SP). Junho de 2011. Disponível em:

<http://www.crpsp.org. $\mathrm{br} /$ portal/midia/fiquedeolho ver.aspx?id=365>

Nota Técnica sobre o Processo Transexualizador e pelo Conselho Federal. 2013. Disponível em: <https://site.cfp.org.br/wp-content/uploads/2013/09/Nota-t\%C3\%A9cnicaprocesso-Trans.pdf>

Nota Técnica $n^{\circ}$ 24/2015 - Ministério da Educação - Debate dimensão de gênero e orientação sexual nos planos de educação. <http://www.spm.gov.br/assuntos/conselho/nota-tecnica-no24-conceito-genero-no-pne-mec.pdf>

Plano Nacional de Educação (PNE 2014-2014): Disponível em: <https://www.planalto.gov.br/ccivil_03/_ato2011-2014/2014/lei//13005.htm>

Parecer CNE/CP $\quad \mathbf{N}^{\circ}$ 8/2012. Disponível em: $<$ http://portal.mec.gov.br/index.php?option=com_docman\&view=download\&alias=10389pcp008-12-pdf\&category_slug=marco-2012-pdf\&Itemid=30192>

Plano Nacional de Políticas para Mulheres (PNPM 2013-2015). Disponível em: <http://www.spm.gov.br/assuntos/pnpm/publicacoes/pnpm-2013-2015-em-22ago13.pdf>

II Plano Nacional de Enfrentamento ao Tráfico de Pessoas (II PNETP - 2013). Disponível em: $<$ https://www.unodc.org/documents/lpo-brazil/noticias/2013/04/2013-04-

08_Folder_IIPNETP_Final.pdf> 
Plano Nacional LGBT (2009). Disponível em: <http://www.arco-iris.org.br/wpcontent/uploads/2010/07/planolgbt.pdf>

Portaria № 766, de 3 de junho de 2013. Institui o Sistema Nacional de Promoção de Direitos e Enfrentamento à Violência Contra Lésbicas, Gays, Bissexuais, Travestis e Transexuais LGBT e dá outras providências. <https://seguro.mprj.mp.br/documents/112957/1508730/Portaria_N766_2013.pdf>

Portaria $\mathbf{N}^{\circ}$ 233, 18 de maio de 2010. Institui direito ao nome social de funcionários no âmbito do governo federal. Disponível em: <ftp://ftp.saude.sp.gov.br/ftpsessp/bibliote/informe_eletronico/2010/iels.mai.10/lels94/U_PTMPOG-GM-233_180510.pdf>

207

Portaria $n^{\circ} 2.803$, de 19 de novembro de 2013. Redefine e amplia o processo transexualizador no sistema único de saúde (SUS). Disponível em: <http://bvsms.saude.gov.br/bvs/saudelegis/gm/2013/prt2803_19_11_2013.html>

Portaria $\mathrm{n}^{\circ} 2.837$, de $1^{\circ}$ de dezembro de 2011. Redefine o comitê técnico de saúde integral de lésbicas, gays, bissexuais, travestis e transexuais (Comitê Técnico LGBT). Disponível em: <http://bvsms.saude.gov.br/bvs/saudelegis/gm/2011/prt2837_01_12_2011.html>

Portaria $\mathrm{n}^{\circ} 2.836$, de $1^{\circ}$ de dezembro de 2011. Institui, no âmbito do Sistema Único de Saúde (SUS), a Política Nacional de Saúde Integral de Lésbicas, Gays, Bissexuais, Travestis e Transexuais (Política Nacional de Saúde Integral LGBT). Disponível em: <http://bvsms.saude.gov.br/bvs/saudelegis/gm/2011/prt2836_01_12_2011.html>

Portaria $\mathrm{n}^{0} 1.644$, de 27 de agosto de 2009. Institui no âmbito do Sistema Único de Saúde (SUS), a Política Nacional de Atenção Integral à Saúde do Homem. Disponível em: <http://www.saude.mt.gov.br/upload/legislacao/1944-\%5B2949-120110-SES-MT\%5D.pdf>

Portaria $\mathrm{n}^{\circ} 1.820$, de 13 de agosto de 2006. Dispõe sobre os direitos e deveres dos usuários da saúde. Disponível em: <http://bvsms.saude.gov.br/bvs/saudelegis/gm/2009/prt1820_13_08_2009.html>

Política Nacional de Atenção Integral à Saúde da Mulher. Princípios e diretrizes. 2004. Disponível em: <http://bvsms.saude.gov.br/bvs/publicacoes/politica_nac_atencao_mulher.pdf>

Resoluções, Deliberações, Decretos e Portarias. Projeto de Lei 01-00652/2015. Institui o Transcidadania, destinado à promoção travestis e transexuais em situação de vulnerabilidade social. Disponível em: <http://documentacao.camara.sp.gov.br/iah/fulltext/projeto/PL06522015.pdf>

Resolução Conselho Nacional de Combate à Discriminação de LGBT (CNCD/LGBT) N. ${ }^{012 / 2015}$. Garantias e condições de acesso de pessoas travestis e transexuais nos Sistemas e Instituições de Ensino. Disponível em:<http://www.sdh.gov.br/sobre/participacaosocial/cncd-lgbt/resolucoes/resolucao-012>

Resolução Conselho Federal de Psicologia (CFP) N. ${ }^{\circ}$ 007/2003 - Parecer Psicológico. Disponível em:<http://site.cfp.org.br/wp-content/uploads/2003/06/resolucao2003 7.pdf> 
Resolução $n^{0} 1$ conjunta do Conselho Nacional de Combate à Discriminação - CNCD-LGBT e do Conselho Nacional de Políticas Criminais e Penitenciaria - CNPCP, de 15 de abril de 2014. Disponível em: <http://justica.gov.br/seus-direitos/politica-penal/politicas2/diversidades/normativos-2/resolucao-conjunta-no-1-cnpc-e-cncd_lgbt-15-de-abril-de2014.pdf $>$

Resolução № 11, de 18 de dezembro de 2014. Estabelece os parâmetros para a inclusão dos itens "orientação sexual", "identidade de gênero" e "nome social" nos boletins de ocorrência emitidos pelas autoridades policiais do Brasil. Disponível em: <http://www.sdh.gov.br/sobre/participacao-social/cncd-lgbt/resolucoes/resolucao-011>

Resolução $n^{\circ} 2$, de 6 de dezembro de 2011. Estabelece estratégias e ações que orientam o plano operativo da política nacional de saúde integral de lésbicas, gays, bissexuais, travestis e transexuais, no âmbito do sistema único de saúde (SUS). Disponível em: <http://www.conass.org.br/wp-content/uploads/2017/02/CIT2-2011.pdf>

Resolução CNE/CP $\quad n^{\circ} \quad 1 / 2012$. Disponível em: $<$ http://portal.mec.gov.br/index.php?option=com_docman\&view=download\&alias=10889rcp001-12\&category_slug=maio-2012-pdf\&ltemid=3019 


\begin{tabular}{|c|c|c|c|c|c|}
\hline \multicolumn{6}{|c|}{$\begin{array}{c}\text { APÊNDICE B: MAPA TEMÁTICO - ENTREVISTAS COM AS PESSOAS PARTICIPANTES DO PROGRAMAS } \\
\text { TRANSCIDADANIA } 01\end{array}$} \\
\hline Participante & Educação & Direitos e Cidadania & Violência física & Conjuntura política & Empregabilidade \\
\hline Felipe & $\begin{array}{l}\text { (144-153) } 121 \text { "É, foi } \\
\text { graças ao projeto que } \\
\text { eu consegui estudar, } \\
\text { porque eu não tinha } \\
\text { saco pra ir à escola, } \\
\text { essa que é a palavra } \\
\text { correta. Porque eu ia } \\
\text { pra escola, você não } \\
\text { é respeitado como } \\
\text { você tem que ser, } \\
\text { não aceitam seu } \\
\text { nome social, aí você } \\
\text { fica passando } \\
\text { constrangimento, } \\
\text { você não vai no } \\
\text { banheiro, porque não } \\
\text { tem um banheiro que } \\
\text { você possa usar, } \\
\text { porque se ninguém } \\
\text { me respeita como } \\
\text { Felipe eu não posso } \\
\text { usar o masculino, se } \\
\text { eu entrar no feminino } \\
\text { as meninas saem } \\
\text { gritando. Aí eu tentei } \\
\text { ainda algumas } \\
\text { vezes, e falei, quer }\end{array}$ & $\begin{array}{l}\text { (66-73) "Eu fico com uma } \\
\text { raiva, que tudo que eu } \\
\text { tenho que fazer eu tenho } \\
\text { que mostrar documento. Aí } \\
\text { quando você puxa o } \\
\text { documento está aquele } \\
\text { nome lindo, maravilhoso, } \\
\text { estampado, assim, no } \\
\text { documento. Aí a pessoa } \\
\text { fala que o documento não } \\
\text { é seu. Ontem quase que } \\
\text { eu não voto. "Não, mas } \\
\text { esse título não é seu”. Dá } \\
\text { uma olhadinha aí no RG". } \\
\text { "Ah, desculpa". "Eu só } \\
\text { quero votar, posso ir?". } \\
\text { Ela, "não, vai lá”. Ai, que } \\
\text { saco. Dá uma raiva } \\
\text { quando você vai fazer } \\
\text { essas coisas." } \\
\text { (305-310) "Eu cheguei a } \\
\text { ter postado no Face uma } \\
\text { vez, acho que é Maria } \\
\text { Aparecida, não é, o nome } \\
\text { da Xuxa? Uma coisa } \\
\text { assim. Aí tinha a foto dela, }\end{array}$ & $\begin{array}{l}\text { (318-320) "Se bem que } \\
\text { até hoje eu ainda tenho } \\
\text { receio de usar o } \\
\text { banheiro, porque eu } \\
\text { tenho medo de } \\
\text { apanhar, não nego." } \\
\text { (375-376) "... É, eu não } \\
\text { confio nem um pouco, } \\
\text { pra falar a verdade, } \\
\text { nada, zero." tomei } \\
\text { (382 - 391) " Eu não } \\
\text { confio, já tom eu cara } \\
\text { bastante enquadro, eu } \\
\text { acho que eu tenho cara } \\
\text { de maloqueiro, eu não } \\
\text { sei. Se eu tiver, eu } \\
\text { gosto. Mas eu já tomei } \\
\text { bastante enquadro e, } \\
\text { tipo, não é legal, você é } \\
\text { mais humilhado do que } \\
\text { os caras cis que tomam } \\
\text { enquadro com você. } \\
\text { (...) Porque aí o cara te } \\
\text { revista, ele começa a } \\
\text { gritar no meio da rua }\end{array}$ & $\begin{array}{l}\text { (402-405) "Alckmin, João } \\
\text { Dória. Aí tem Temer, aí o } \\
\text { outro que vai se } \\
\text { candidatar é o } \\
\text { Bolsonaro, que eu não } \\
\text { duvido nada que ganhe. } \\
\text { Vou pra Cuba, gente, } \\
\text { Brasil não dá mais." } \\
\text { (551- 556) "Ou então, } \\
\text { coisa que eu não duvido } \\
\text { é que ele pode falar "não, } \\
\text { vamos cortar esse } \\
\text { projeto porque isso não é } \\
\text { importante pra cidade, } \\
\text { isso não vai levar a } \\
\text { cidade a lugar nenhum, a } \\
\text { cidade precisa de outras } \\
\text { coisas mais importantes, } \\
\text { vou cortar. Ajudar viado? } \\
\text { Viado que se foda". Eu } \\
\text { tenho certeza que é bem } \\
\text { isso que ele vai falar. Eu } \\
\text { acho que ele vai falar, } \\
\text { "não, isso daqui não vai } \\
\text { mudar nada na minha } \\
\text { vida, vamos tirar isso daí }\end{array}$ & $\begin{array}{l}\text { (139-141) "Eu } \\
\text { precisava } \\
\text { trabalhar. Quem } \\
\text { que vai conseguir } \\
\text { trabalhar se você } \\
\text { não fez nem a } \\
\text { oitava série? Quem } \\
\text { vai te contratar?" } \\
\text { (434-437) "Está. } \\
\text { Eu nunca fiquei } \\
\text { tanto tempo parado } \\
\text { assim. Tem quase } \\
\text { um ano que eu } \\
\text { estou parado, } \\
\text { nunca passei por } \\
\text { isso. Minha mulher } \\
\text { está há um mês, } \\
\text { ela está parada } \\
\text { desde dezembro, } \\
\text { não arruma } \\
\text { emprego de jeito } \\
\text { nenhum." }\end{array}$ \\
\hline
\end{tabular}

${ }^{121}$ Número das linhas da transcrição sequencial. 


\begin{tabular}{|c|c|c|c|}
\hline $\begin{array}{l}\text { saber, vou comprar } \\
\text { um histórico, não vou } \\
\text { estudar mais não. Aí } \\
\text { comprei, realmente, } \\
\text { comprei r um } \\
\text { histórico." } \\
\text { (203-218) "Foi, eu } \\
\text { estava em casa e } \\
\text { uma amiga minha me } \\
\text { falou. Ela falou, } \\
\text { "Felipe, você não } \\
\text { terminou a escola, } \\
\text { né?", eu falei "eu } \\
\text { não". Ela "pô, tem um } \\
\text { projeto bacana pra } \\
\text { gente, } \\
\text { Transcidadania, por } \\
\text { que que você não vai } \\
\text { lá? Aí você volta a } \\
\text { estudar". Aí eu falei } \\
\text { "ai, Érica, estudar } \\
\text { não. Não, não, não, } \\
\text { eu não tenho boas } \\
\text { lembranças de de } \\
\text { escola, não quero". } \\
\text { Ela, "deixa eu falar?", } \\
\text { eu falei, "deixo". } \\
\text { “Meu, é um projeto só } \\
\text { para transexuais, } \\
\text { eles vão te respeitar } \\
\text { como você é, vão te } \\
\text { pôr numa escola que } \\
\text { vão te respeitar, você } \\
\text { não vai ter problema }\end{array}$ & $\begin{array}{l}\text { aí todo mundo chama ela } \\
\text { de Xuxa, todo mundo } \\
\text { chama o Augusto Liberato } \\
\text { de Gugu, todo mundo } \\
\text { chama Sr. Abravanel de } \\
\text { Silvio Santos. Por que que } \\
\text { ninguém pode me chamar } \\
\text { de Felipe? " }\end{array}$ & $\begin{array}{l}\text { pra todo mundo ouvir } \\
\text { "eu não pus a mão na } \\
\text { sua boceta, não, viu? } \\
\text { Você não quer ser } \\
\text { homem? Vai apanhar } \\
\text { que nem homem". Será } \\
\text { que essa e e a } \\
\text { preparação que eles } \\
\text { estão tendo?" }\end{array}$ & $\begin{array}{l}\text { e vamos pôr, sei lá, } \\
\text { vamos pegar o dinheiro } \\
\text { que gastava com isso e } \\
\text { vamos pôr ônibus, } \\
\text { vamos fazer alguma } \\
\text { outra coisa e vamos } \\
\text { deixar eles lá. Não tem } \\
\text { que ajudar eles, não, } \\
\text { eles que se virem"." }\end{array}$ \\
\hline
\end{tabular}




\begin{tabular}{|c|c|c|c|c|c|}
\hline & $\begin{array}{l}\text { nenhum quanto a } \\
\text { isso, vai receber uma } \\
\text { bolsa pra ajudar } \\
\text { você, aí você vai } \\
\text { receber para estudar } \\
\text { e ainda vai ser } \\
\text { respeitado. Por que } \\
\text { que você não vai lá } \\
\text { ver?". Eu falei, "ah, } \\
\text { sendo assim acho } \\
\text { que dá pra dar uma } \\
\text { olhada". Ela falou, } \\
\text { "vai lá". Aí eu vim no } \\
\text { começo do ano, em } \\
\text { janeiro. Aí não tinha } \\
\text { vaga. Aí eu fiquei na } \\
\text { fila de espera. } \\
\text { Quando foi em junho } \\
\text { eles me ligaram pra } \\
\text { eu vir aqui que tinha } \\
\text { surgido a vaga. Aí eu } \\
\text { entrei e, graças a } \\
\text { Deus, já estou quase } \\
\text { terminando a oitava } \\
\text { série." }\end{array}$ & & & & \\
\hline Christiane & $\begin{array}{l}\text { (108-120) " Eu parei } \\
\text { na oitava série, não } \\
\text { tive a oportunidade, } \\
\text { assim, de estudar, } \\
\text { porque o meu pai era } \\
\text { alcoólatra, minha } \\
\text { mãe era deficiente, } \\
\text { minha mãe é } \\
\text { deficiente, minha } \\
\text { mãe é cega, e é eu e } \\
\text { mais uma irmã, e } \\
\text { minha irmã é mais }\end{array}$ & $\begin{array}{l}(77-81) \text { "Então. E esse } \\
\text { mundo de travesti, } \\
\text { transexual, é um mundo } \\
\text { sofrido, assim, por causa } \\
\text { das pessoas que nos } \\
\text { julgam como aberração, } \\
\text { entendeu? E não veem a } \\
\text { gente como ser humano, } \\
\text { veem a gente como } \\
\text { aberração, como monstro. } \\
\text { Eu acho que não é bem }\end{array}$ & $\begin{array}{l}\text { (232-237) "Tem travesti } \\
\text { até que se mata porque } \\
\text { é muita pressão em } \\
\text { cima dela, é muito } \\
\text { preconceito em cima } \\
\text { dela, que ela não } \\
\text { suporta, que ela cai na } \\
\text { depressão, da } \\
\text { depressão ela tenta um } \\
\text { suicídio, tem vez que } \\
\text { consegue e tem vez } \\
\text { que não consegue, }\end{array}$ & $\begin{array}{l}\text { (202-206) "E, no caso, } \\
\text { sobre o GLBT, eu } \\
\text { espero, o Temer eu não } \\
\text { tenho muita esperança } \\
\text { nele, que ele veja a } \\
\text { gente com humanidade, } \\
\text { com respeito, porque se } \\
\text { ele está querendo tirar } \\
\text { até décimo terceiro de } \\
\text { pessoas que, deficiente, } \\
\text { que trabalhou a vida } \\
\text { inteira, imagina a gente." }\end{array}$ & $\begin{array}{l}(81-90) \text { "(...) Dói, } \\
\text { porque só quem } \\
\text { sofre na pele sabe } \\
\text { que dói, porque eu } \\
\text { já perdi várias } \\
\text { oportunidades de } \\
\text { emprego por ser } \\
\text { travesti. Porque } \\
\text { teve, eu fui lá no } \\
\text { [...] como auxiliar } \\
\text { de limpeza, foi no } \\
\text { dia da entrevista }\end{array}$ \\
\hline
\end{tabular}




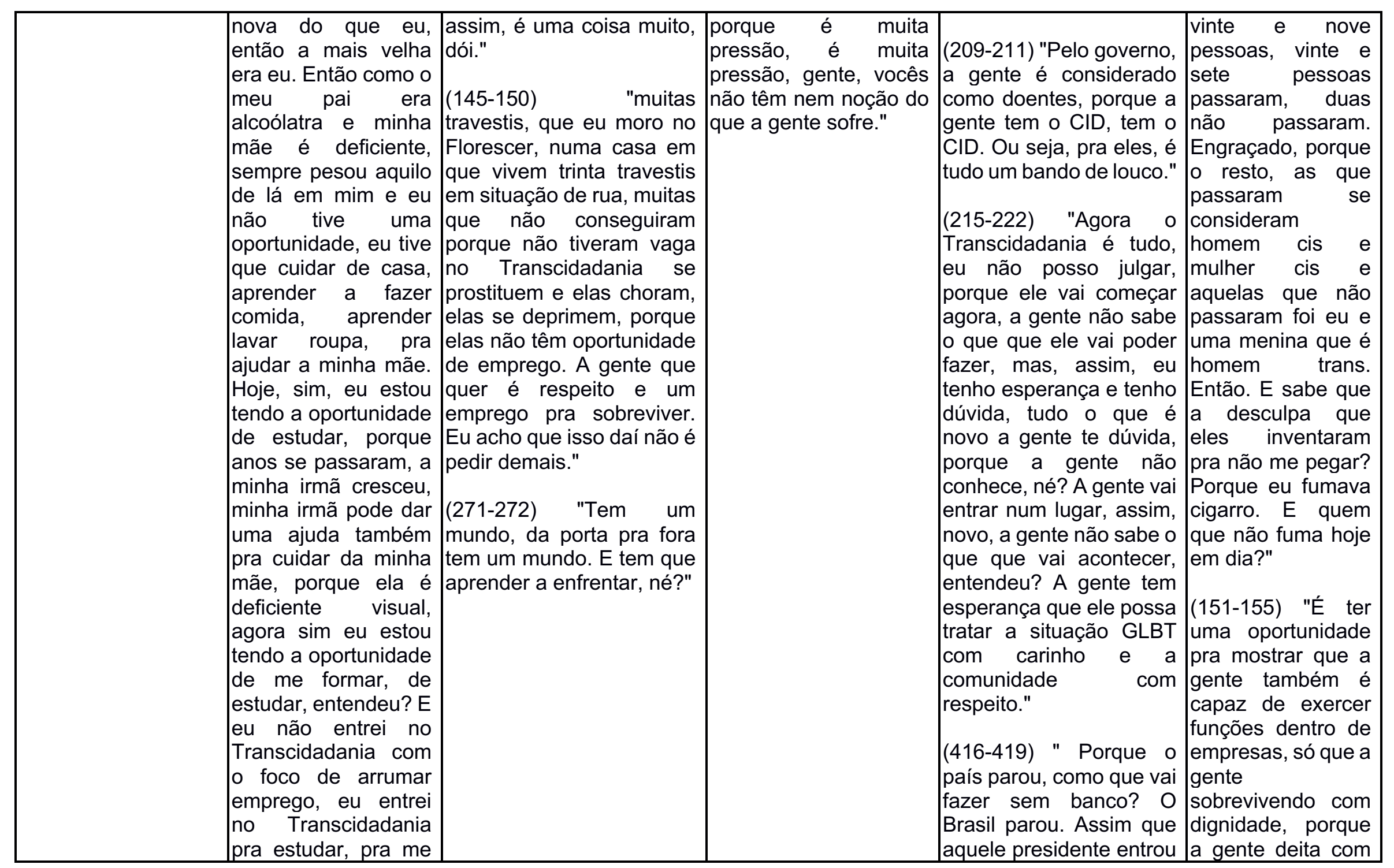




\begin{tabular}{|c|c|c|c|c|c|}
\hline & $\begin{array}{l}\text { formar, pra fazer } \\
\text { uma, como que eu } \\
\text { posso falar, terminar } \\
\text { os estudos pra me } \\
\text { profissionalizar, } \\
\text { entendeu?" }\end{array}$ & & & $\begin{array}{l}\text { ali, o } \text { Brasil parou, } \\
\text { porque, gente, vai ter } \\
\text { tanto vandalismo. Tipo } \\
\text { assim, não é culpa } \\
\text { dessas pessoas, é culpa } \\
\text { dos governantes." }\end{array}$ & $\begin{array}{l}\text { trinta homens, dez } \\
\text { homens na noite, } \\
\text { imagina quando a } \\
\text { gente acaba, volta } \\
\text { pra casa, que } \\
\text { cabeça que a gente } \\
\text { tem?" } \\
\text { (158-163) } \\
\text { Entendeu? Ou } \\
\text { porque, por mais } \\
\text { os outros falar "ah, } \\
\text { se você está } \\
\text { ganhando porque } \\
\text { você está fazendo } \\
\text { sexo é uma coisa } \\
\text { boa". Não é assim, } \\
\text { a gente só vai } \\
\text { trabalhar porque a } \\
\text { gente precisa, } \\
\text { porque morrer de } \\
\text { fome ninguém } \\
\text { quer. E se as } \\
\text { empresas não } \\
\text { abrem prara } \\
\text { oportunidade pra } \\
\text { gente trabalhar, } \\
\text { dar um emprego } \\
\text { pra gente, a gente } \\
\text { vai fazer como? " }\end{array}$ \\
\hline \begin{tabular}{|l} 
Aline \\
\end{tabular} & $\begin{array}{l}(75-82) \text { " "ai meu } \\
\text { Deus do céu, será? } \\
\text { Voltar pra escola, } \\
\text { voltar a fazer curso? } \\
\text { E aquela cicatriz que } \\
\text { ficou lá? Dos dez, } \\
\text { oito, nove anos de }\end{array}$ & $\begin{array}{l}\text { (129-131) "É importante, } \\
\text { principalmente pra quem } \\
\text { passou séculos e décadas, } \\
\text { e décadas sem ser vista, } \\
\text { achando que o único lugar } \\
\text { da gente é rua, camisinha } \\
\text { e gel. " }\end{array}$ & $\begin{array}{l}\text { (11-17) "E você se vê } \\
\text { numa situação de rua, } \\
\text { tem que ir pra rua, é } \\
\text { travesti, travesti na rua. } \\
\text { E você viver numa } \\
\text { prostituição, momentos } \\
\text { que você ri, momentos }\end{array}$ & & \begin{tabular}{|lr}
$(214-119)$ & "Então \\
assim, eu tenho \\
muito & medo, \\
porque e as que \\
entraram agora, \\
em 2016, já não \\
vão completar dois
\end{tabular} \\
\hline
\end{tabular}




\begin{tabular}{|c|c|c|c|c|}
\hline & $\begin{array}{l}\text { idade, } r \\
\text { preconceito, apanhar } \\
\text { de amigo, ser } \\
\text { xingada, aquela } \\
\text { coisa toda?". A } \\
\text { Atena, "não, vai ser } \\
\text { bacana", eu "ai, sei } \\
\text { lá". Aí eu parei e } \\
\text { pensei, "pelo menos } \\
\text { eu vou voltar a } \\
\text { estudar, eu não vou } \\
\text { ficar parada, igual } \\
\text { aqui. Aqui, se eu ficar } \\
\text { dois anos eu vou sair } \\
\text { com uma mão na } \\
\text { frente e outra atrás. } \\
\text { Lá, eu vou aprender, } \\
\text { eu vou ter curso, eu } \\
\text { vou ter uma } \\
\text { oportunidade, quem } \\
\text { sabe, né?". " }\end{array}$ & $\begin{array}{l}(165-169) \quad \text { "Ah, sim, } \\
\text { respeito, alegria, } \\
\text { dignidade, olhar de cabeça } \\
\text { erguida pra qualquer um, } \\
\text { sem ter medo, não olhar } \\
\text { pra baixo, olhar pra cima e } \\
\text { dizer: "eu sou ser humano, } \\
\text { sou uma travesti, sim, sou } \\
\text { digna, sustento uma casa, } \\
\text { eu tenho uma mãe, eu } \\
\text { tenho um amor e posso ser } \\
\text { como qualquer outra } \\
\text { pessoa, lutar...". " }\end{array}$ & $\begin{array}{l}\text { que você chora, } \\
\text { momentos que você } \\
\text { corre risco, momentos } \\
\text { que você olha pro céu, } \\
\text { olha pra noite, pede a } \\
\text { Deus pra te tirar dali, } \\
\text { mas não tem saída, é } \\
\text { ali que você tem que } \\
\text { ficar. Você vê amigas } \\
\text { chegando, amigas } \\
\text { morrendo, correndo } \\
\text { risco de doenças, de } \\
\text { tudo que não presta, } \\
\text { pelo simples objetivo } \\
\text { de sobreviver" }\end{array}$ & 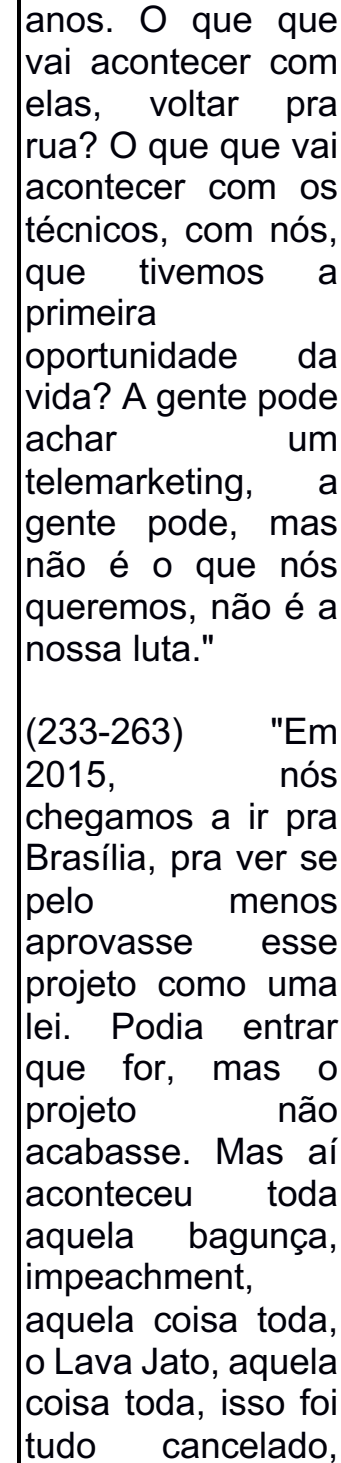 \\
\hline
\end{tabular}




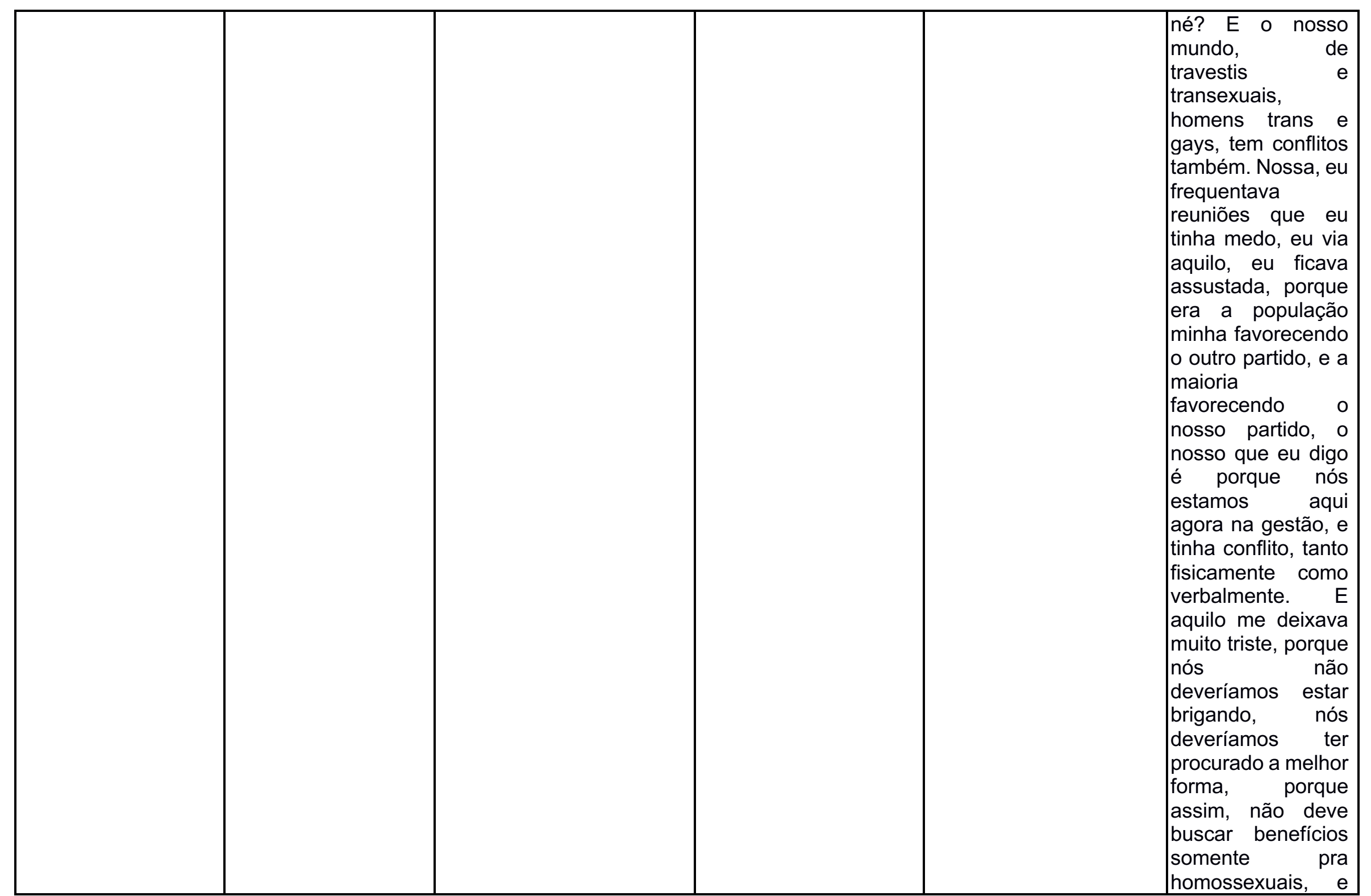




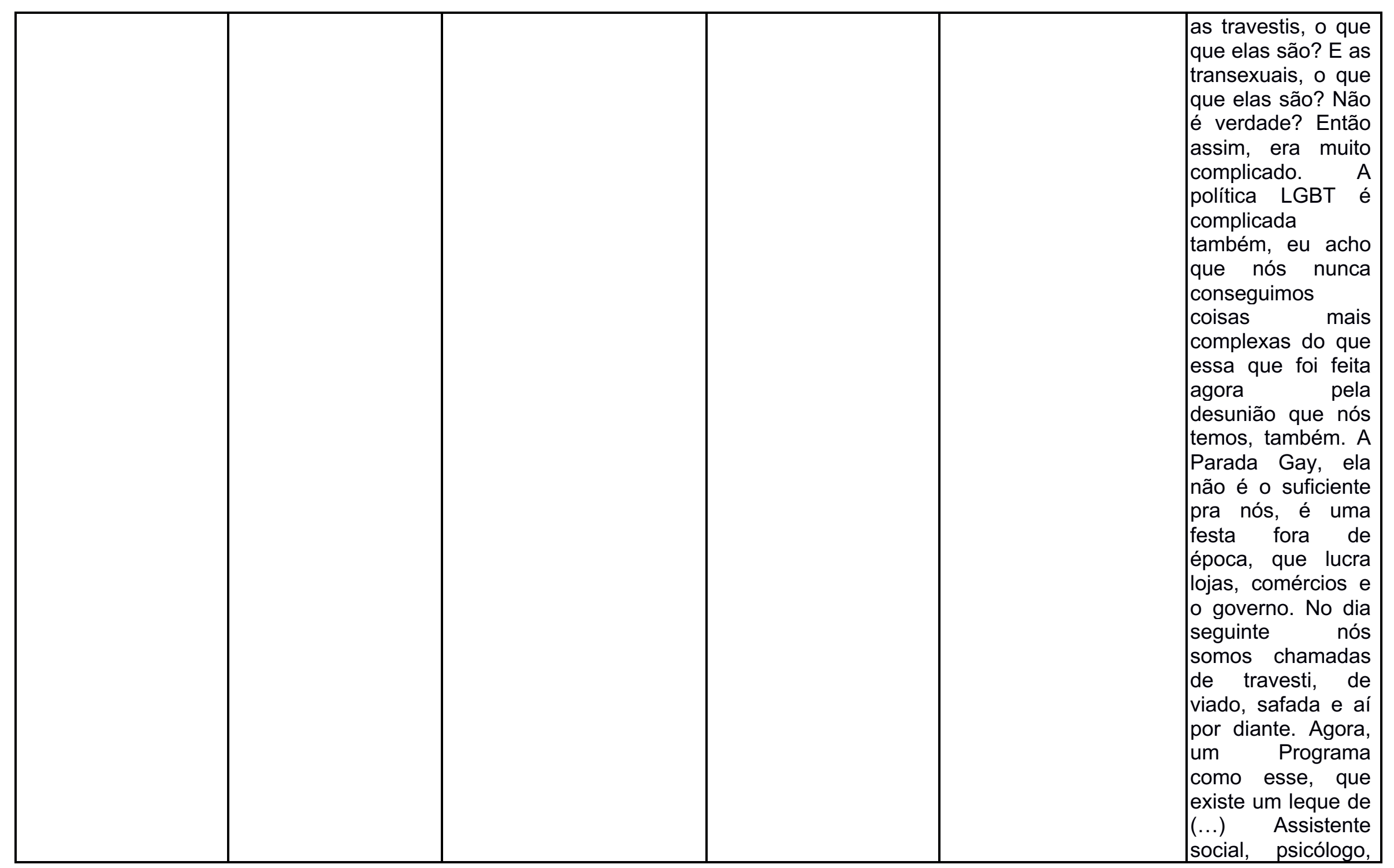




\begin{tabular}{|c|c|c|c|c|}
\hline & & & & $\begin{array}{l}\text { advogado, uma } \\
\text { coordenadora, } \\
\text { oportunidade de } \\
\text { emprego, } \\
\text { oportunidade de de } \\
\text { voltar à escola, } \\
\text { visibilidade, curso } \\
\text { der Direitos } \\
\text { Humanos, curso do } \\
\text { Senai, cursos que } \\
\text { eles vão buscando } \\
\text { parceria e uma } \\
\text { bolsa pra ajudar } \\
\text { elas a não se } \\
\text { empenharem tanto } \\
\text { no meio de uma } \\
\text { rua pra não perder } \\
\text { a escola. Aonde } \\
\text { nós vamos } \\
\text { encontrar isso } \\
\text { novamente?" }\end{array}$ \\
\hline Luciano & \begin{tabular}{|l|}
$(61-72)$ “então num \\
primeiro momento, \\
eu lembro muito bem \\
do meu primeiro dia \\
de aula, foi um pouco \\
tenso por conta da do \\
nome social e as \\
listas que estavam na \\
parede da escola \\
estava com nome da \\
falecida, ramas \\
automaticamente eu \\
fui conversar com a \\
diretoria e na época a \\
Symmy fazia essa \\
ponte e ela estava lá,
\end{tabular} & $\begin{array}{l}\text { (18-28)“Existe um Luciano } \\
\text { antes do Transcidadania e } \\
\text { outro depois do } \\
\text { transcidadania. Pra mim } \\
\text { foi muito importante por } \\
\text { vários motivos assim, mas } \\
\text { dentre eles, antes do } \\
\text { TransCidadania, antes de } \\
\text { eu fazer o curso de direitos } \\
\text { humanos - na época do } \\
\text { meu tempo de programa } \\
\text { existia esse curso para } \\
\text { gente, eu não tinha, } \\
\text { assim, eu eu pensava que } \\
\text { a gente não tinha direito } \\
\text { né? Assim, uma vez que a }\end{array}$ & $\begin{array}{l}\text { (76-80) "cara eu em } \\
\text { choque quando eu vejo } \\
\text { essas coisas porque } \\
\text { assim a gente luta tanto } \\
\text { para nossas garantias a } \\
\text { massa da população } \\
\text { LGBT mas da população } \\
\text { em geral para ter seus } \\
\text { direito para que tudo } \\
\text { ocorra na medida do } \\
\text { possível bem e a gente } \\
\text { vê uma informação } \\
\text { dessa aí e a gente fica } \\
\text { assim sei lá tem dia que } \\
\text { eu fico assim eu paro e } \\
\text { fico observando algumas }\end{array}$ & $\begin{array}{l}\text { (51-57)“então eu tô } \\
\text { bem graças a Deus } \\
\text {, eu tô feliz, eu tô } \\
\text { trabalhando né. Fiz } \\
\text { dois anos na } \\
\text { empresa que eu } \\
\text { estou agora. Me } \\
\text { ajudou ro } \\
\text { Transcidadania me } \\
\text { ajudou porque } \\
\text { assim né, fiz os } \\
\text { cursos, terminei a } \\
\text { escola pela } \\
\text { TrasCidadania. Sai } \\
\text { um ano antes do } \\
\text { projeto né, porque }\end{array}$ \\
\hline
\end{tabular}




\begin{tabular}{|c|c|c|}
\hline 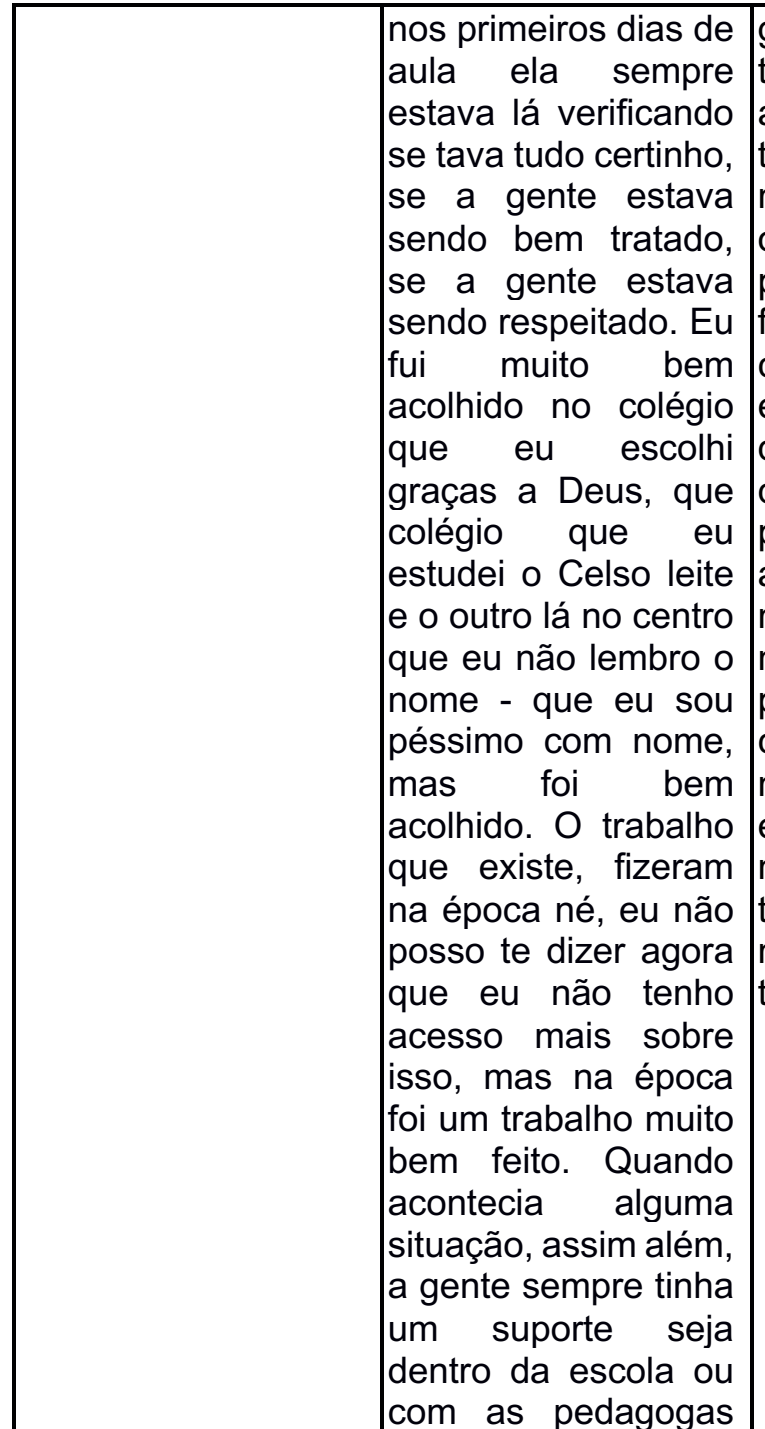 & $\begin{array}{l}\text { gente é transexual ou } \\
\text { travesti no Brasil eu } \\
\text { achava que a gente não } \\
\text { tinha direitos. Embora, } \\
\text { mesmo não sabendo que } \\
\text { os tinha eu sempre lutei } \\
\text { por isso sabe, eu sempre } \\
\text { fui atrás de correr, sempre } \\
\text { corri atrás das coisas que } \\
\text { eu achava que era de meu } \\
\text { direito e depois que eu fiz, } \\
\text { que eu participei do } \\
\text { programa e tive certo } \\
\text { alguns cursos que para } \\
\text { mim foi muito importante } \\
\text { no meu desenvolvimento } \\
\text { pessoal, como na minha } \\
\text { comunidade, não só na } \\
\text { minha comunidade onde } \\
\text { eu vivo, onde eu moro aqui } \\
\text { no Capão Redondo mas } \\
\text { também na questão dos } \\
\text { meus iguais os homens } \\
\text { trans." }\end{array}$ & 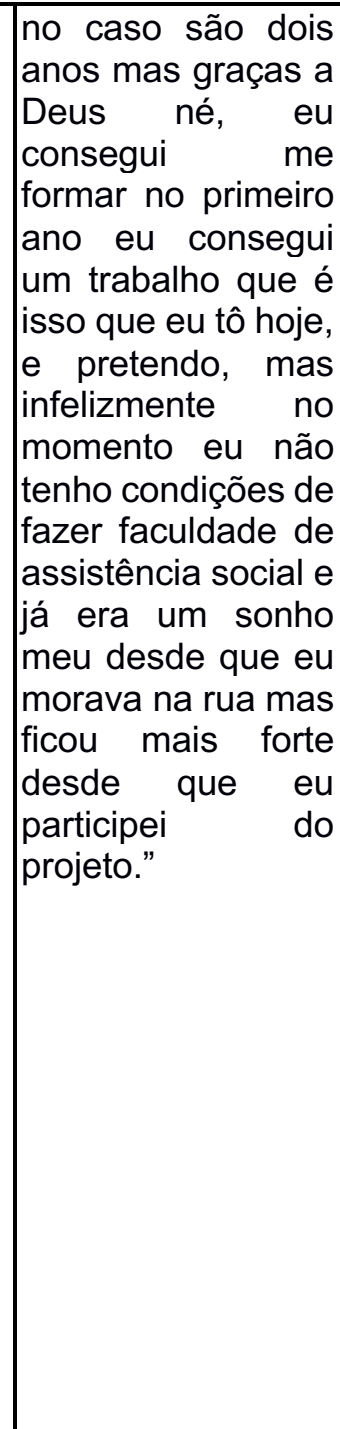 \\
\hline
\end{tabular}




\begin{tabular}{|c|c|c|c|c|c|}
\hline & $\begin{array}{l}\text { que nos } \\
\text { acompanhavam." }\end{array}$ & & & & \\
\hline Amanda & 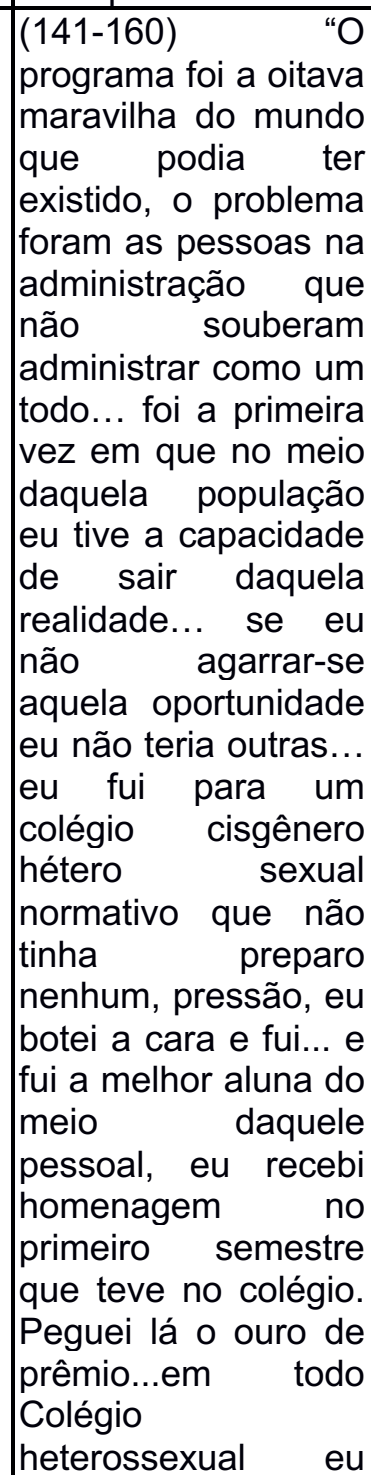 & \begin{tabular}{|l} 
(29-24) "Porque antes do \\
TransCidadania, a \\
Amanda marfero era o \\
que? Era mais uma garota \\
de programa, transexual, \\
que tava na rua, se \\
prostituindo, que não sabia \\
ter direitos como cidadão, \\
nem direitos nem deveres, \\
não sabia que no quinto \\
paragrafo da constituição, \\
somos todos iguais \\
perante a lei, né. Não sabia \\
nem que podia entrar \\
numa câmara, que dirá \\
gritar pelos nossos \\
direitos. Então esse \\
programa me tirou, me deu \\
a visão, né, do mundo \\
como um todo." \\
(58-60) "Sim foi a melhor \\
coisa que me aconteceu \\
da minha vida. Foi um \\
divisor de aguas, né. \\
Porque... Porque me fez \\
me enxergar como uma \\
mulher transexual que sou, \\
na sociedade com direitos \\
e deveres como cidadão. \\
Que antes eu não sabia de \\
nada sobre isso." \\
(61-69) "Então, foi através \\
do programa,
\end{tabular} & $\begin{array}{l}\text { (32-35) "Se hoje eu } \\
\text { tenho cicatrizes, como, } \\
\text { hoje eu tenho } \\
\text { dificuldade pra fala, eu } \\
\text { não tenho uma fala } \\
\text { legal, eu não sei bonito, } \\
\text { eu não sei falar. } \\
\text { Porque? Porque eu } \\
\text { não tive preparo pra } \\
\text { isso. Não tive preparo } \\
\text { porque? Porque eu tive } \\
\text { que tá numa esquina } \\
\text { pra me prostituir desde } \\
\text { nova." }\end{array}$ & $\begin{array}{l}\text { (103-109) "se um } \\
\text { bolsonaro da vida entrar } \\
\text { e tudo vai por água } \\
\text { abaixo, ele pode... } \\
\text { Nossa... de repente } \\
\text { voltar até, Deus me livre, } \\
\text { a uma ditadura até } \\
\text { coisas piores né? então } \\
\text { eu acho que é continuar } \\
\text { nesse caminho a pessoa } \\
\text { ter consciência no voto, a } \\
\text { pessoa também que vai } \\
\text { voltar né? ... o que eu } \\
\text { fico pensando é uma } \\
\text { população LGBT às } \\
\text { vezes bota três milhões } \\
\text { numa parada e não } \\
\text { consegue eleger Um } \\
\text { representante LGBT lá". }\end{array}$ & 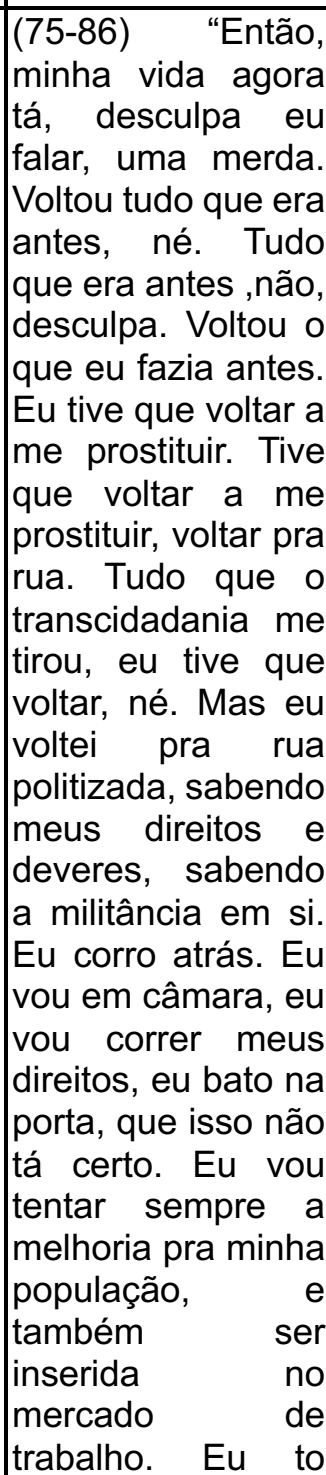 \\
\hline
\end{tabular}




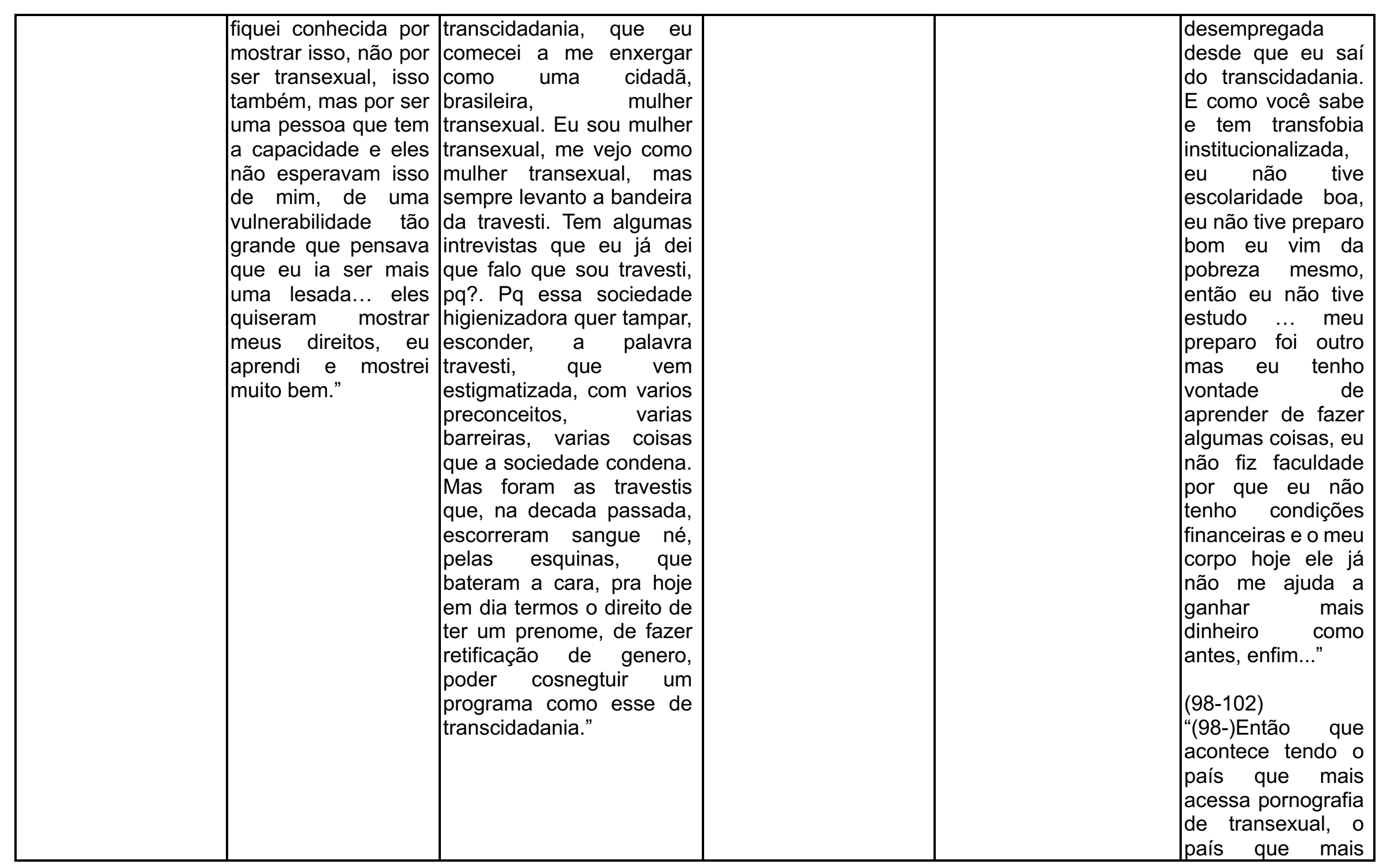




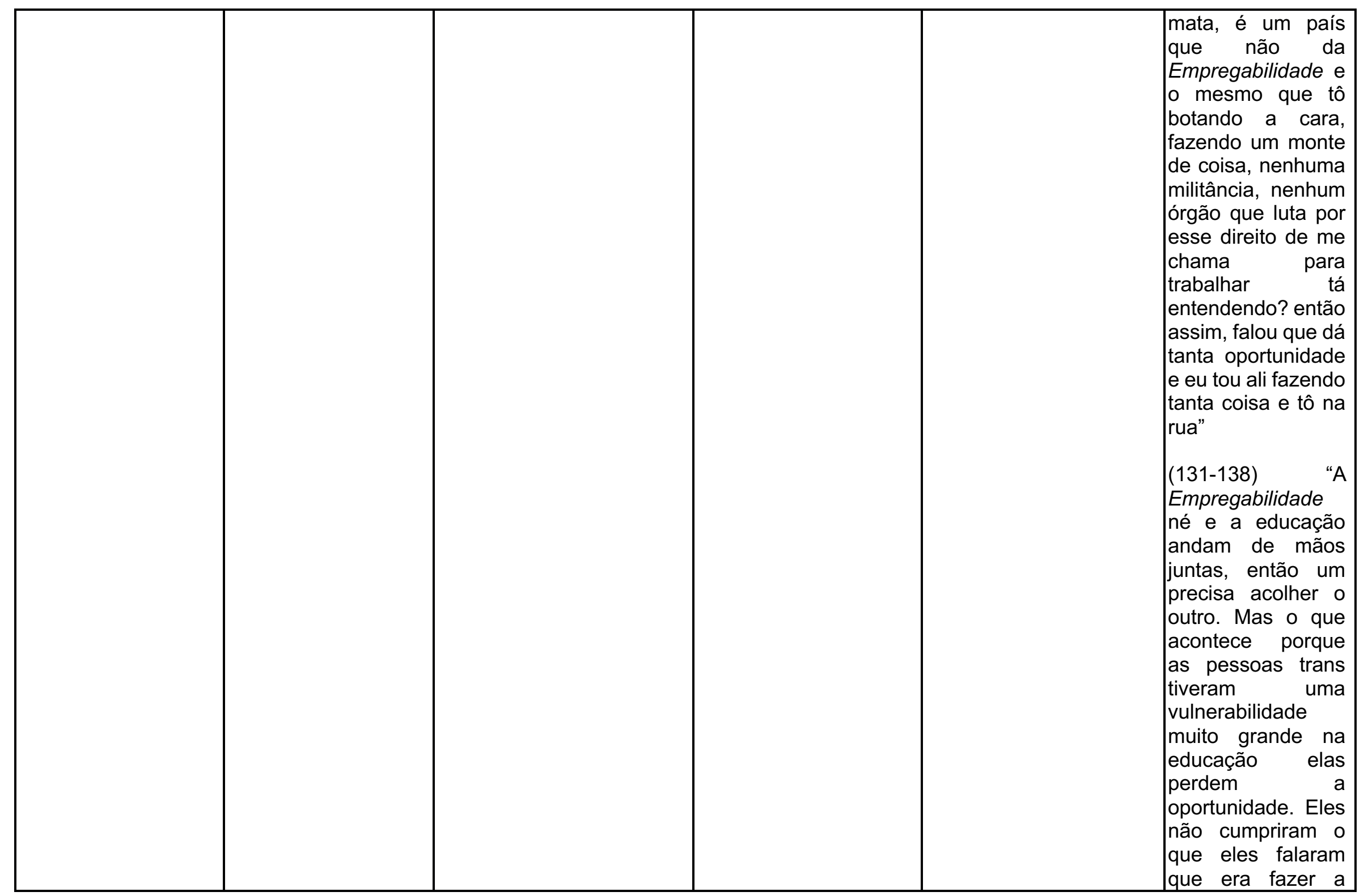




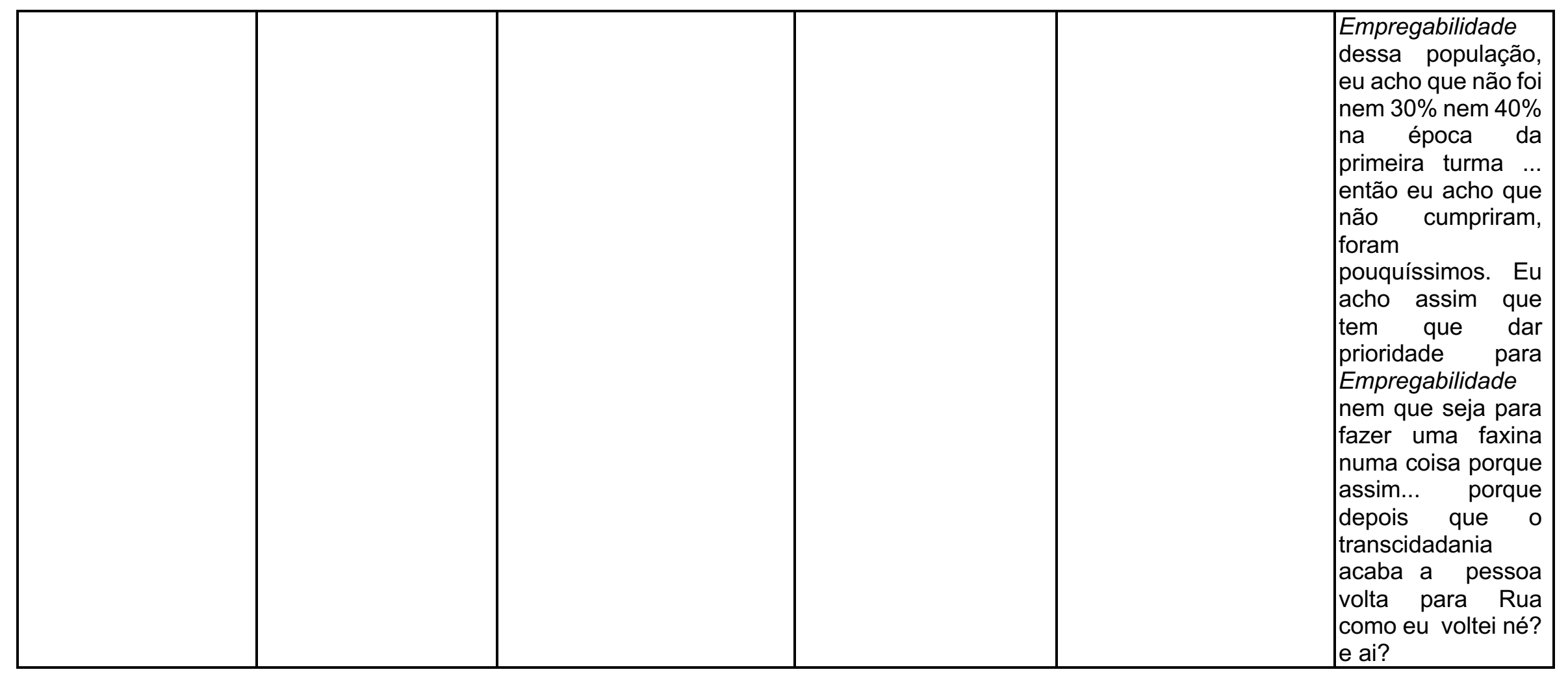




\title{
ANEXOS
}

\section{ANEXO 1 :DECRETO N 55.874, DE 29 DE JANEIRO DE 2015}

\author{
DECRETO N 55.874, DE 29 DE JANEIRO DE 2015
}

Institui o Programa TransCidadania, destinado à promoção da cidadania de travestis e transexuais em situação de vulnerabilidade social; altera disposições dos Decretos $n^{\circ} 44.484$, de 10 de março de 2004, e n 40.232, de 2 de janeiro de 2001.

FERNANDO HADDAD, Prefeito do Município de São Paulo, no uso das atribuições que the são conferidas por lei,

D E CRETA:

Art. $1^{\circ}$ Fica instituído o Programa TransCidadania, destinado a promover os direitos humanos, o acesso à cidadania e a qualificação e humanização do atendimento prestado a travestis e transexuais em situação de vulnerabilidade social.

Art. $2^{\circ}$ São diretrizes do Programa TransCidadania:

I - oferta de condições de autonomia financeira e de enfrentamento à pobreza, por meio de programas redistributivos, de elevação de escolaridade, qualificação profissional e intermediação de mão de obra;

II - desenvolvimento de ações de enfrentamento ao preconceito e à discriminação contra travestis e transexuais e de respeito à expressão de sua identidade de gênero e ao uso do nome social, nos termos do Decreto $n^{\circ} 51.180$, de 14 de janeiro de 2010;

III - capacitação e sensibilização permanentes dos servidores públicos municipais para a oferta de atendimento qualificado e humanizado a pessoas travestis e transexuais, observados os princípios da dignidade da pessoa humana, da igualdade e da não revitimização;

IV - formação cidadã em direitos humanos para o exercício da cidadania, participação popular e controle social.

Art. $3^{\circ}$ Compete à Secretaria Municipal de Direitos Humanos e Cidadania:

I - acompanhar e avaliar, em articulação com as demais Secretarias Municipais, a implementação do Programa;

II - encaminhar e auxiliar os beneficiários do Programa na adesão a outros programas e ações públicos e na obtenção de outros benefícios a que possam fazer jus;

III - referenciar equipamentos municipais, em especial das redes de saúde, assistência social e de apoio à mulher, para atendimento e acolhimento de pessoas travestis e transexuais;

IV - prestar apoio técnico e financeiro à execução das atividades previstas no Programa.

Parágrafo único. O referenciamento previsto no inciso III do "caput" deste artigo não impede nem exclui o atendimento de pessoas travestis e transexuais nos demais equipamentos públicos.

Art. $4^{\circ} \mathrm{A}$ rede municipal de saúde deverá ofertar, nos equipamentos municipais a serem referenciados, a terapia hormonal, no âmbito do Processo Transexualizador e pelo Sistema Único de Saúde (SUS), conforme Portaria n².803, de 19 de novembro de 2013, do Ministério da Saúde.

Art. $5^{\circ}$ Os artigos $2^{\circ}$ e 17 do Decreto $n^{\circ} 44.484$, de 10 de março de 2004, passam a vigorar com as seguintes alterações:

"Art. $2^{\circ}$

Parágrafo único. A Secretaria Municipal de Direitos Humanos e Cidadania poderá celebrar convênios, parcerias ou termos de cooperação específicos para o desenvolvimento de atividades pelos beneficiários provenientes do Programa TransCidadania, respeitadas as normas e diretrizes do POT. " (NR)

"Art. 17.

VII - Secretaria Municipal de Direitos Humanos e Cidadania." (NR) 
Art. $6^{\circ} \mathrm{O}$ artigo $8^{\circ}$ do Decreto $\mathrm{n}^{\circ} 40.232$, de 2 de janeiro de 2001, passa a vigorar acrescido do $\S 3^{\circ}$, com a seguinte redação:

"Art. $8^{\circ}$

$\S 3^{\circ} \mathrm{Na}$ realização de censos de caráter qualitativo, deverão constar as classificações quanto à orientação sexual e à identidade de gênero, destinadas a subsidiar a elaboração de políticas públicas voltadas aos respectivos segmentos de lésbicas, gays, bissexuais, travestis e transexuais." (NR)

Art. $7^{\circ}$ Todas as unidades da Administração Municipal Direta e Indireta que prestam atendimento ao público deverão afixar, em local visível, placa contendo a seguinte mensagem: "De acordo com o Decreto $n^{\circ} 51.180$, de 14 de janeiro de 2010, os órgãos e entidades da Administração Municipal Direta e Indireta devem respeitar e usar o nome social das pessoas travestis e transexuais."

Art. $8^{\circ}$ Este decreto entrará em vigor na data de sua publicação.

PREFEITURA DO MUNICÍPIO DE SÃO PAULO, aos 29 de janeiro de 2015, 462 da fundação de São Paulo.

FERNANDO HADDAD, PREFEITO

ROGÉRIO SOTTILI, Secretário Municipal de Direitos Humanos e Cidadania

ARTUR HENRIQUE DA SILVA SANTOS, Secretário Municipal do Desenvolvimento, Trabalho e Empreendedorismo

FRANCISCO MACENA DA SILVA, Secretário do Governo Municipal

Publicado na Secretaria do Governo Municipal, em 29 de janeiro de 2015. 


\title{
ANEXO 2 : DECRETO N 44.484, DE 10 DE MARÇO DE 2004
}

\author{
REGULAMENTA O PROGRAMA OPERAÇÃO TRABALHO, INSTITUÍDO PELA LEI N ${ }^{\circ}$ \\ 13.178, DE 17 DE SETEMBRO DE 2001, COM A REDAÇÃO DADA PELA LEI N $\underline{13.689}$, \\ DE 19 DE DEZEMBRO DE 2003.
}

MARTA SUPLICY, Prefeita do Município de São Paulo, no uso das atribuições que the são conferidas por lei, DECRETA:

Art. $1^{\circ} \mathrm{O}$ Programa Operação Trabalho, instituído no Município de São Paulo pela Lei $\mathrm{n}^{\circ}$ 13.178 , de 17 de setembro de 2001, alterada pela Lei $n^{\circ} \underline{13.689}$, de 19 de dezembro de 2003, fica regulamentado na conformidade das disposições constantes deste decreto.

Art. $2^{\circ}$ Os beneficiários do Programa Operação Trabalho desenvolverão suas atividades junto aos órgãos da Administração Municipal Direta e Indireta, em outras instituições públicas ou em entidades privadas, com as quais a Secretaria do Desenvolvimento, Trabalho e Solidariedade - SDTS celebre convênios, parcerias ou termos de cooperação, vedada toda e qualquer atividade insalubre, nos termos das normas trabalhistas vigentes.

Parágrafo Único - A Secretaria Municipal de Direitos Humanos e Cidadania poderá celebrar convênios, parcerias ou termos de cooperação específicos para o desenvolvimento de atividades pelos beneficiários provenientes do Programa TransCidadania, respeitadas as normas e diretrizes do POT. (Redação acrescida pelo Decreto nº $\underline{55.874 / 2015)}$

Art. $3^{\circ} \mathrm{A}$ participação no Programa fica limitada ao máximo de 2 (duas) pessoas por núcleo familiar.

Parágrafo Único - Excepcionalmente, o limite estipulado no "caput" deste artigo poderá ser excedido, mediante declaração das Secretarias Municipais da Saúde e de Assistência e Desenvolvimento Social, atestando a condição de pessoa em situação de vulnerabilidade social e uso abusivo de substâncias psicoativas, no limite das vagas disponíveis. (Redação acrescida pelo Decreto $n^{\circ} \underline{5067 / 2014)}$

Art. $4^{\circ} \mathrm{O}$ valor do auxílio pecuniário a ser concedido aos beneficiários fica condicionado às modalidades previstas no artigo $2^{\circ}$ da Lei $n^{\circ} \underline{13.178}$, de 2001, com a redação dada pela Lei $n^{\circ} 13.689$, de 2003, bem como à carga horária estipulada para as respectivas atividades e a eventual prorrogação da participação dos interessados no Programa Operação Trabalho, podendo variar entre o mínimo de dois quintos e o máximo de um e meio salário mínimo nacional vigente, de acordo com a disponibilidade de recursos financeiros.

Parágrafo Único - Até a regularização da documentação básica pessoal para saque do auxílio pecuniário com cartão magnético, os beneficiários do Programa De Braços Abertos atendidos pelo Programa Operação Trabalho poderão receber o valor em espécie, mediante recibo. (Redação acrescida pelo Decreto n $\underline{55067 / 2014)}$

Art. $5^{\circ} \mathrm{O}$ subsídio para despesas de alimentação importará até $10 \%$ (dez por cento) do salário mínimo nacional vigente, sendo concedido aos beneficiários do Programa que participarem do exercício das atividades práticas previstas no inciso I do artigo $2^{\circ}$ da Lei $n^{\circ} \underline{13.178}$, de 2001 , com a redação dada pela Lei $n^{\circ} \underline{13.689}$, de 2003, de acordo com a disponibilidade de recursos financeiros. 
O subsídio para despesas de deslocamento importará até $21,25 \%$ (vinte e um inteiros e vinte e cinco décimos por cento) do salário mínimo nacional vigente e será concedido obrigatoriamente aos beneficiários enquadrados na modalidade prevista no inciso III do artigo $2^{\circ}$ da Lei $n^{\circ} \underline{13.178}$, de 2001 , com a redação dada pela Lei $n^{\circ} \underline{13.689}$, de 2003, podendo ser conferido àqueles que participarem do exercício de atividades práticas referidas no inciso I do mesmo dispositivo legal, conforme a disponibilidade de recursos financeiros.

Art. $7^{\circ} \mathrm{A}$ carga horária das atividades do Programa será de, no máximo, 6 (seis) horas diárias, até o limite de 30 (trinta) horas semanais, distribuídas entre as atividades práticas e de capacitação ocupacional e cidadania, em proporcionalidade que atenda à especificidade de cada curso e à condição pessoal de cada beneficiário, respeitada a legislação trabalhista.

$\S 1^{\circ}$ As ações de incentivo à conduta do beneficiário e de orientação sobre seu comportamento no sentido de buscar ocupação serão desenvolvidas por meio de cursos, palestras, seminários e outras atividades similares, bem como visitas a empresas que estejam oferecendo vagas no mercado formal de trabalho.

$\S 1^{\circ}$ As ações de incentivo à conduta do beneficiário e de orientação sobre seu comportamento no sentido de buscar ocupação serão desenvolvidas por meio de cursos, palestras, seminários e outras atividades similares, incluindo visitas a empresas que estejam oferecendo emprego, e contemplarão a elevação de sua auto-estima, possibilitando-Ihe adotar cuidados com sua imagem, indumentária convencional, postura e linguagem adequadas, em entrevistas para colocação no mercado de trabalho. (Redação dada pelo Decreto $n^{\circ} \underline{44.661 / 2004)}$

$\S 2^{\circ}$ As atividades previstas no $\S 1^{\circ}$ deste artigo terão a duração definida em portaria, conforme critérios estabelecidos pela Coordenação do Programa.

Art. $8^{\circ}$ As pessoas beneficiárias participantes do Programa poderão justificar apenas $10 \%$ (dez por cento) de faltas por mês, em relação à freqüência mensal total às atividades práticas e de capacitação ocupacional e cidadania.

$\S 1^{\circ}$ Para os fins do limite estabelecido no "caput" deste artigo, não serão computadas até 3 (três) faltas decorrentes de falecimento de pai, mãe, irmãos, filhos e cônjuge, casamento e doença, devidamente comprovadas pelos respectivos atestados e certidões emitidos por órgãos públicos ou por entidades conveniadas com o Poder Público.

$\S 1^{\circ}$ Para os fins do limite estabelecido no "caput" deste artigo, não serão computadas até 3 (três) faltas decorrentes de falecimento de pai, mãe, irmãos, filhos e cônjuge e casamento, devidamente comprovadas pelos respectivos atestados e certidões emitidos por órgãos públicos ou por entidades conveniadas com o Poder Público. (Redação dada pelo Decreto ${ }^{\circ}$ $\underline{55067 / 2014)}$

$\S 2^{\circ}$ Em caso de impossibilidade de exercício das atividades, o beneficiário poderá permanecer afastado do Programa, ficando suspenso o pagamento dos benefícios e mantida a data final prevista no Termo de Compromisso e Responsabilidade, nas seguintes hipóteses:

I - a critério médico, pelo período necessário à sua recuperação;

II - por detenção ou reclusão em estabelecimento prisional, pelo período certificado pela autoridade policial ou judicial. 
$\S 3^{\circ} \mathrm{Em}$ caso de acidente ocorrido no exercício de atividades práticas e de capacitação ocupacional e cidadania, o beneficiário ficará afastado, a critério médico, não sofrendo desconto no valor dos benefícios durante o respectivo período e não sendo excluído do Programa, ao qual deverá retornar quando considerado apto, desde que ainda não esgotado o prazo fixado no Termo de Compromisso e Responsabilidade.

$\S 4^{\circ}$ Para as ações de incentivo à conduta do beneficiário e de orientação sobre seu comportamento no sentido de buscar ocupação, a freqüência deverá ser de $100 \%$ (cem por cento), ressalvadas as hipóteses previstas nos incisos I e II do $\S 2^{\circ}$ deste artigo, sendo que os benefícios previstos nos incisos $\mathrm{VI}$, quando for o caso, e no inciso VII do artigo $2^{\circ}$ da Lei $\mathrm{n}^{\circ}$ $\underline{13.178}$, de 2001 , com a redação dada pela Lei $n^{\circ} \underline{13.689}$, de 2003 , somente serão liberados mediante a comprovação da presença a todas as atividades programadas.

$\S 5^{\circ} \mathrm{O}$ descumprimento do disposto neste artigo acarretará o desligamento do beneficiário, com a revogação do Termo de Compromisso e Responsabilidade e a cessação dos benefícios do Programa.

$\S 6^{\circ}$ Não haverá cômputo de faltas ou suspensão de pagamento de benefícios para os beneficiários do Programa no caso de impossibilidade de exercício das atividades decorrente de motivos de saúde, mediante atestado médico. (Redação acrescida pelo Decreto $\mathrm{n}^{\circ}$ $\underline{55067 / 2014)}$

Art. $9^{\circ} \mathrm{Na}$ hipótese de desligamento do beneficiário, voluntário ou a critério da respectiva Coordenação, cessará imediatamente a concessão dos benefícios do Programa.

Art. 10 Caberá à Coordenação do Programa definir a data do pagamento dos benefícios pecuniários e os critérios de aferição da freqüência e da apuração de faltas, que serão atestadas pelos responsáveis dos órgãos onde estiverem alocados os beneficiários.

Art. 11 Nas hipóteses de óbito do beneficiário, de sua detenção ou reclusão em estabelecimento prisional ou de sua internação em unidade médica por problemas de saúde, poderão ser pagos os benefícios pecuniários devidos em razão de atividades já desenvolvidas, desde que o próprio beneficiário, seu procurador, cônjuge, companheiro (a) ou herdeiro assim o requeira administrativamente, no prazo de 90 (noventa) dias, contados do término do prazo de 60 (sessenta) dias consecutivos da data do depósito do beneficio, na forma do $\S 5^{\circ}$ do artigo $2^{\circ}$ da Lei $n^{\circ} \underline{13.178}$, de 2001 , com a redação dada pela Lei $n^{\circ} \underline{13.689}$, de 2003.

Parágrafo Único - O requerimento a ser protocolizado junto à Coordenadoria do Programa Operação Trabalho deverá ser acompanhado, obrigatoriamente, por certidões, atestados ou declarações emitidas por entidades públicas ou conveniadas com o Poder Público.

Art. 12 Se constatada a inadaptação do beneficiário às atividades práticas e de capacitação ocupacional e cidadania, bem como de ações de incentivo e de orientação à conduta no sentido de buscar ocupação, caberá à Coordenação do Programa determinar seu remanejamento para outras atividades ou, até mesmo, o seu desligamento.

Art. 13 Aos beneficiários que vierem a desenvolver atividades práticas em creches, é obrigatória a apresentação à Coordenação do Programa de atestado de saúde fornecido pelo órgão indicado pela secretaria municipal competente.

Art. $14 \mathrm{Em}$ caso de persistir empate na seleção dos interessados após a aferição dos requisitos e critérios previstos nos artigos $3^{\circ}$ e $6^{\circ}$ da Lei $n^{\circ} \underline{13.178}$, de 2001, com a redação dada pela Lei $n^{\circ} \underline{13.689}$, de 2003, caberá à Coordenação do Programa deliberar sobre a escolha do beneficiário, com base nas peculiaridades de carência apuradas em entrevista pessoal dos candidatos. 
Art. 15 A aferição da renda e dos demais requisitos para a concessão dos benefícios será realizada quando do cadastramento inicial, da assinatura do Termo de Compromisso e Responsabilidade e em qualquer fase posterior, a critério da respectiva Coordenação.

$\S 1^{\circ}$ Para fins de comprovação dos requisitos previstos para a habilitação no Programa, estabelecidos no artigo $3^{\circ}$ da Lei $n^{\circ} \underline{13.178}$, de 2001, com a redação dada pela Lei $n^{\circ} \underline{13.689}$, de 2003, consideram-se os seguintes documentos:

I - de residência: todo e qualquer documento emitido por instituição pública ou privada que contenha, no mínimo, o nome do selecionado e seu endereço no Município de São Paulo, a data de emissão ou postagem de documentos, como carnê do Imposto Predial e Territorial Urbano - IPTU, contas de luz, água, telefone ou gás, contratos e recibos de locação de imóvel em nome do beneficiário, carteira de inscrição em unidades de saúde, carteira de vacinação de filhos, acompanhada das respectivas certidões de nascimento, correspondência recebida no período de até 2 (dois) anos antes de efetivada a inscrição no Programa ou declaração fornecida por entidades públicas ou privadas, bem como por pessoa física cuja firma esteja reconhecida, no caso de domicílio que não seja oficializado no Cadastro Imobiliário da Prefeitura do Município de São Paulo;

II - da situação de desempregado: Carteira de Trabalho e Previdência Social, recibos ou declarações, certidão emitida por sindicato ou entidade de classe ou declaração do próprio interessado, sob as penas previstas no artigo $9^{\circ}$ da Lei $n^{\circ} 13.178$, de 2001 , e na legislação penal, de desemprego mínimo de 4 (quatro) meses, ou de não ter acumulado, nos últimos 36 (trinta e seis) meses, mais de 3 (três) meses de registro na referida carteira profissional;

III - de renda bruta familiar e/ou individual: recibos, holerites, Carteira de Trabalho e Previdência Social, declaração do empregador ou do tomador de serviços, comprovantes de valores recebidos a qualquer título de órgãos públicos ou entidades particulares, tais como pensões, aposentadorias, pecúlios e demais rendas ou, ainda, declaração do próprio interessado na hipótese de desenvolver atividade eventual ou de economia informal, além de outros que possibilitem a comprovação dos rendimentos de cada membro do grupo familiar;

IV - da condição de morador de rua: certidão emitida por associações civis de assistência social, devidamente inscritas no Conselho Municipal de Assistência Social, atestando a condição de morador de rua em processo de reinserção social,

V - de escolaridade: certidão do último ano escolar cursado;

VI - de idade: certidão de nascimento ou de casamento, cédula de identidade, carteira de reservista, ou Carteira de Trabalho e Previdência Social.

$\S 2^{\circ} \mathrm{Na}$ comprovação de residência, estando o carnê do Imposto Predial e Territorial Urbano - IPTU, as contas de luz, água, telefone ou gás, o contrato e recibos de locação de imóvel em nome do cônjuge, companheiro, pais ou representante legal do beneficiário, deverá ser apresentada certidão de casamento, prova hábil de união estável, de filiação ou de representação, além de declaração, sob as penas da lei, da pessoa cujo nome consta do documento, de que o selecionado reside em sua companhia.

$\S 3^{\circ} \mathrm{O}$ cadastro dos beneficiários do Programa e a respectiva documentação comprobatória serão mantidos pela Prefeitura do Município de São Paulo pelo prazo de 10 (dez) anos. 
$\S 4^{\circ} \mathrm{A}$ habilitação dos beneficiários do Programa De Braços Abertos para fins de atendimento pelo Programa Operação Trabalho poderá ser efetuada mediante a comprovação da situação de uso abusivo de substâncias psicoativas e de vulnerabilidade social pelas Secretarias Municipais da Saúde e de Assistência e Desenvolvimento Social. (Redação acrescida pelo Decreto $n^{\circ} \underline{55067 / 2014)}$

Art. 16 À Secretaria do Desenvolvimento, Trabalho e Solidariedade - SDTS caberá efetivar as ações instituídas pela Lei $n^{\circ} \underline{13.178}$, de 2001, alterada pela Lei $n^{\circ} \underline{13.689}$, de 2003, em especial aquelas previstas em seu artigo 10.

Art. 17 A Comissão de Apoio de que trata o artigo 12 da Lei no 13.178, de 2001, será presidida pelo Secretário do Desenvolvimento, Trabalho e Solidariedade e constituída pelos titulares ou por representantes por eles designados, dos seguintes órgãos governamentais e entidades não-governamentais:

I - Secretaria do Desenvolvimento, Trabalho e Solidariedade;

II - Secretaria de Finanças e Desenvolvimento Econômico;

III - Secretaria Municipal de Assistência Social;

IV - Secretaria Municipal de Educação;

V - Secretaria Municipal das Subprefeituras;

VI - instituições da sociedade civil.

Art. 18 As despesas decorrentes da execução deste decreto correrão por conta das dotações orçamentárias próprias.

Art. 19 Este decreto entrará em vigor na data de sua publicação, revogados os Decretos $\mathrm{n}^{\circ} \mathrm{s}$ $\underline{41.207}$, de 3 de outubro de $2001, \underline{41.777}$, de 11 de março de 2002, e $\underline{42.586}$, de 5 de novembro de 2002.

PREFEITURA DO MUNICÍPIO DE SÃO PAULO, aos 10 de março de 2004, 451 da fundação de São Paulo.

MARTA SUPLICY, PREFEITA

LUIZ TARCISIO TEIXEIRA FERREIRA, Secretário dos Negócios Jurídicos

LUÍS CARLOS FERNANDES AFONSO, Secretário de Finanças e Desenvolvimento Econômico

MÁRCIO POCHMANN, Secretário do Desenvolvimento, Trabalho e Solidariedade

Publicado na Secretaria do Governo Municipal, em 10 de março de 2004.

RUI GOETHE DA COSTA FALCÃO, Secretário do Governo Municipal

DATA DE PUBLICAÇÃO: 11/03/2004 


\section{ANEXO 3 : PLANO INDIVIDUAL DE ATENDIMENTO (PIA)}

\section{DATA:}

Número do Registro:

Número do indivíduo:

IDENTIFICAÇÃO

\begin{tabular}{|lc|}
\hline Nome & Social \\
\hline Nome & Civil: \\
\hline End: & Negião : Cidade: \\
\hline Bairro: & (s): Celular: \\
\hline Fone & Cep.: \\
\hline Email: & \\
\hline Contato & \\
\hline Nome: & \\
\hline Telefone/endereço: & \\
\hline
\end{tabular}

DOCUMENTAÇÃO

\begin{tabular}{|c|c|}
\hline Cert. & Nasc.: Livro: Fls $\mathrm{n}^{\circ}$ \\
\hline CTPS: & Série: \\
\hline Titulo & Eleitor: Série: \\
\hline Possui & bilhete de transporte gratuito: ( ) Escola ( ) Especial \\
\hline $\begin{array}{l}\text { PROVIDÊNCIAS } \\
\text { Cert. }\end{array}$ & $\begin{array}{c}\text { TÉCNICAS: } \\
\text { Nasc.:( ) RG ( ) CTPS ( ) CPF ( ) CAM ( ) TE ( ) }\end{array}$ \\
\hline
\end{tabular}

Número do indivíduo: 
PARTE 1: Atendimento Psicossocial Sistematizado

\section{ESCOLARIDADE/ASPECTOS PEDAGÓGICOS}

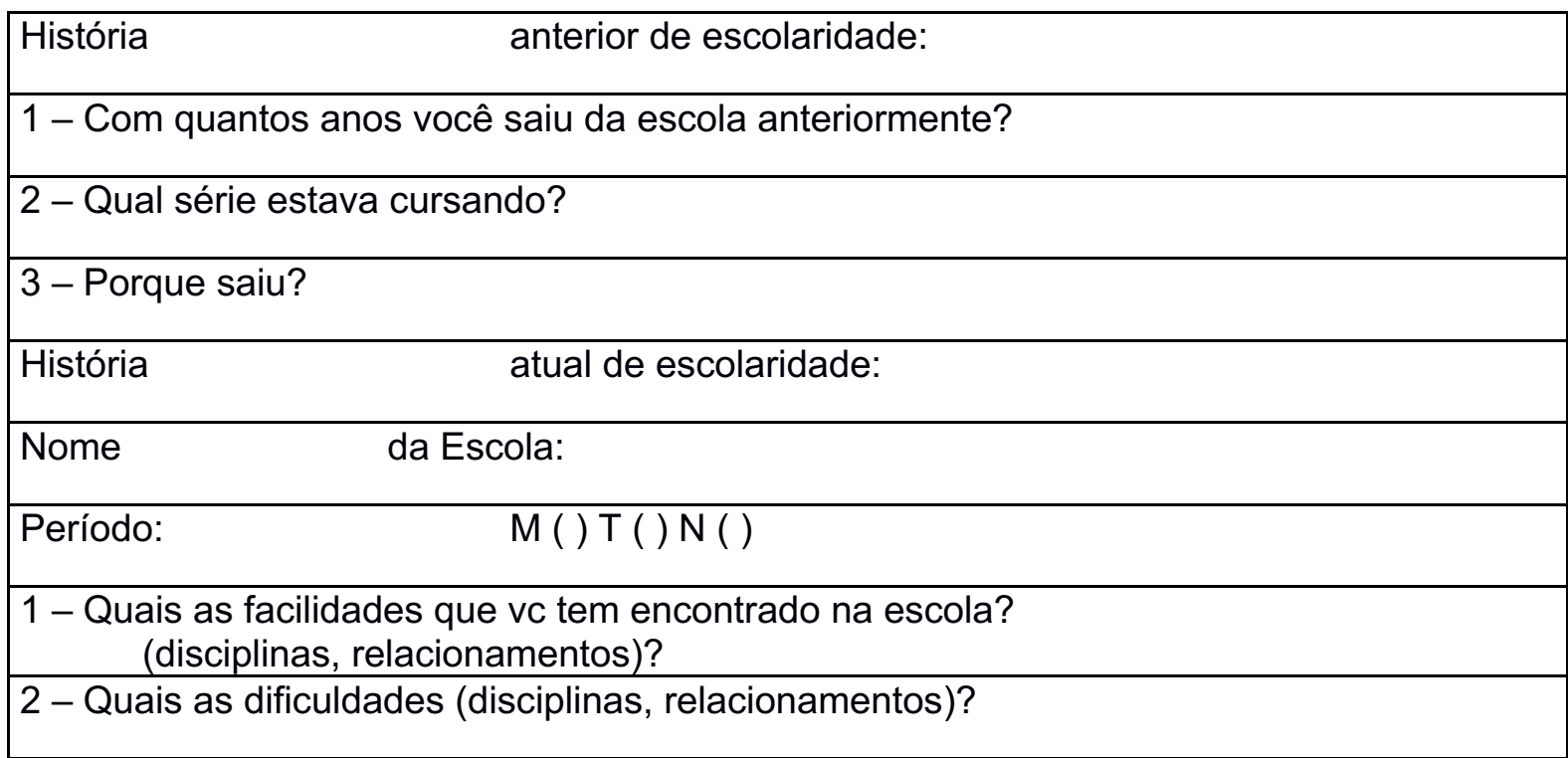

\section{ATIVIDADE LABORATIVA E PROFISSIONALIZAÇÃO}

\begin{tabular}{|c|c|}
\hline Trabalha: & \\
\hline $\begin{array}{l}\text { Função } \\
\text { Esta é sua profissão? ( ) sim ( ) não Qual:( } \\
\text { vínculo empregatício }\end{array}$ & ) Com vínculo empregatício ( ) Sem \\
\hline de Trabalho: & Salário: \\
\hline Empresa: & \\
\hline de interesses profission & \\
\hline $\begin{array}{c}\text { Participa/participou } \\
\text { Quais: }\end{array}$ & o ( ) Sim ( ) \\
\hline
\end{tabular}




\section{CULTURA/LAZER/ESPORTE}

\begin{tabular}{|lc|}
\hline Pratica & algum esporte? Qual? Onde e com que frequência? \\
\hline Frequenta & alguma atividade cultural? \\
\hline Frequenta & alguma atividade de lazer? \\
\hline O & que mais gosta de fazer? \\
\hline PROVIDÊNCIAS & TÉCNICAS: \\
\hline
\end{tabular}

RELIGIÃO

Qual o tipo de crença e/ou religião?

SITUAÇÃO HABITACIONAL

\begin{tabular}{l}
$\begin{array}{l}\text { Casa } \\
\text { ) Próprio ( ) Alugado ( ) Apartamento ( ) Barraco ( ) Pensão } \\
\text { Situação } \\
\text { Qual: }\end{array}$ \\
$\begin{array}{l}\text { Referência } \\
\text { de Rua ( ) Centro de Acolhida ( ) }\end{array}$ \\
\hline Espaço Físico Residencial: quarto ( ) sala ( ) cozinha ( ) wc ( ) \\
\hline $\begin{array}{l}\text { Saneamento básico: pavimentação ( ) água ( ) esgoto ( ) luz ( ) } \\
\text { Quão satisfeita você está com a sua moradia? ( ) Muito Insatisfeita ( ) Insatisfeita ( ) Nem } \\
\text { Satisfeita, Nem Insatisfeita ( ) Satisfeita ( ) Muito Satisfeita }\end{array}$ \\
\hline PROVIDÉNCIAS
\end{tabular}

COMPOSIÇÃO FAMILIAR E LEVANTAMENTO SÓCIO-ECONÔMICO

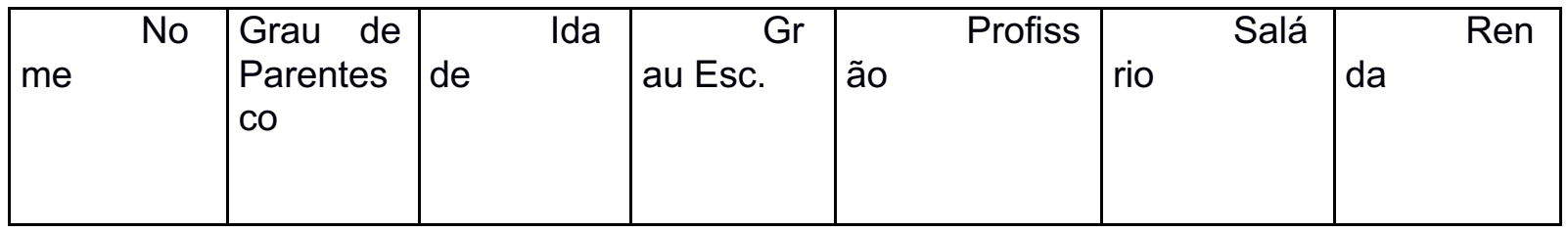

É cadastrado no Cad Único?

PARTICIPA DE ALGUM P.T.R? (Programa de Transferência de Renda)

\begin{tabular}{|l|l|}
\hline Qual? & Valor \\
\hline
\end{tabular}

Qual avaliação que você faz do auxílio (renda) Transcidadania na sua vida? 
SAÚDE

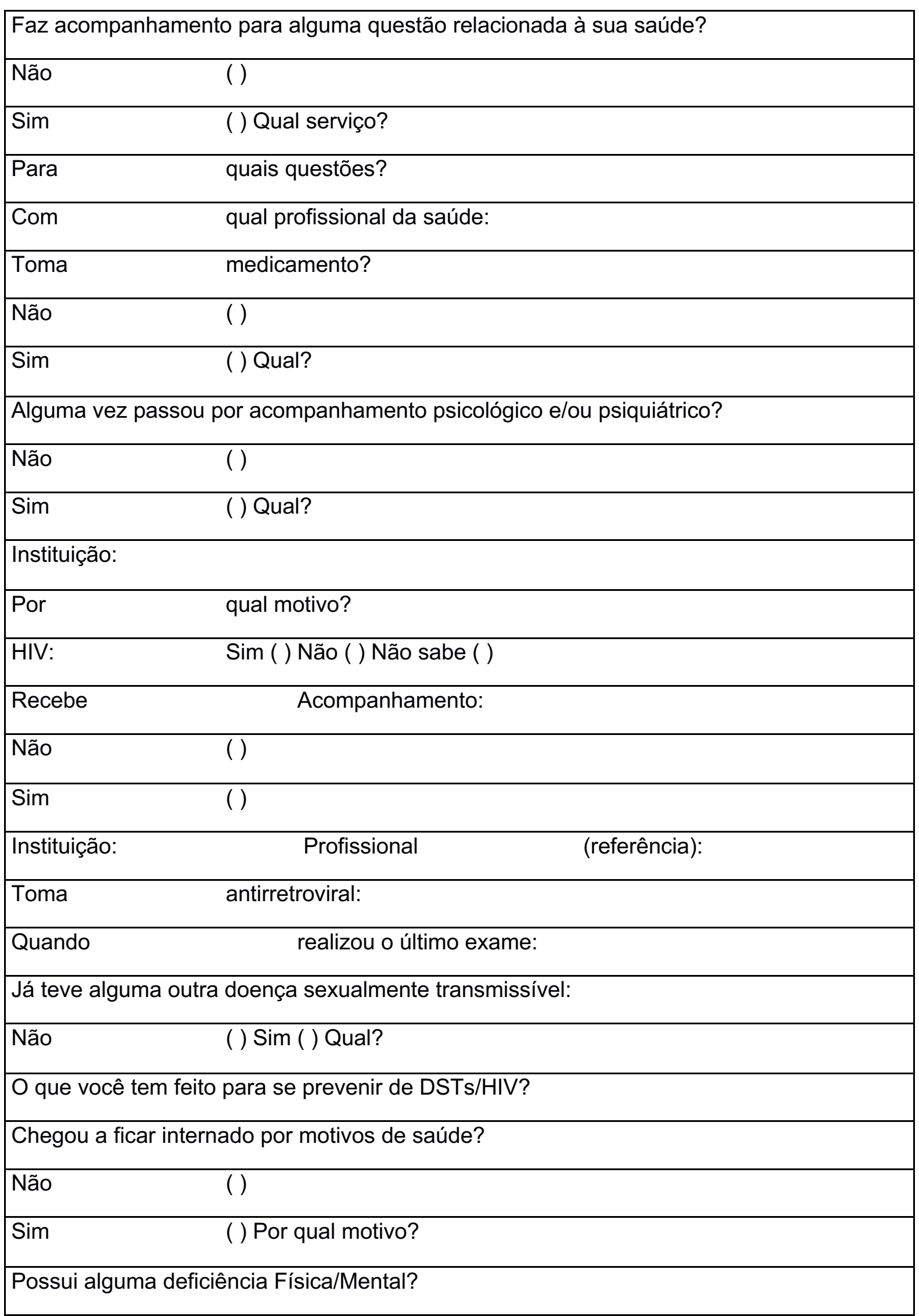




\begin{tabular}{|ll|}
\hline Não & $($ ) \\
\hline Sim & ( ) Qual: \\
\hline Faz uso de substâncias psicoativas (químicas)? Não ( ) & $\operatorname{Sim}($ ) \\
\hline
\end{tabular}

\begin{tabular}{|l|l|ll}
\hline Substâncias & Qual frequência? & $\begin{array}{l}\text { O } \\
\text { cotidiano? }\end{array}$ & uso interfere no \\
\hline
\end{tabular}


Algum familiar, companheiro ou pessoa que convive com você faz uso de substâncias psicoativas (químicas)?

PERCURSO DE TRANSIÇÃO

\begin{tabular}{|c|}
\hline Atualmente qual é o gênero que você se identifica? \\
\hline Homem \\
\hline Mulher \\
\hline Transexual \\
\hline Travesti \\
\hline Transgênero \\
\hline 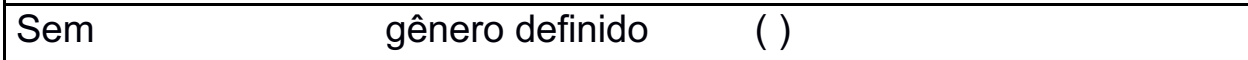 \\
\hline Outra \\
\hline Com que idade você passou a se identificar assim? ___ anos \\
\hline Silicone: \\
\hline() \\
\hline() \\
\hline Tipo $\quad$ (prótese ou líquido): ___ Que serviço colocou: \\
\hline Utiliza hormônios: Não ( ) Sim ( ) Qual? \\
\hline Faz acompanhamento hormonal: Não ( ) Sim ( ) Onde: \\
\hline
\end{tabular}

RELACIONAMENTOS INTERPESSOAIS

Como estão seus vínculos com

Familiares:

Cônjuge/companheiro:

Amigo:

Outros: 


\section{JURÍDICO}

Você tem desejo ou conseguiu realizar mudança do seu nome nos documentos?

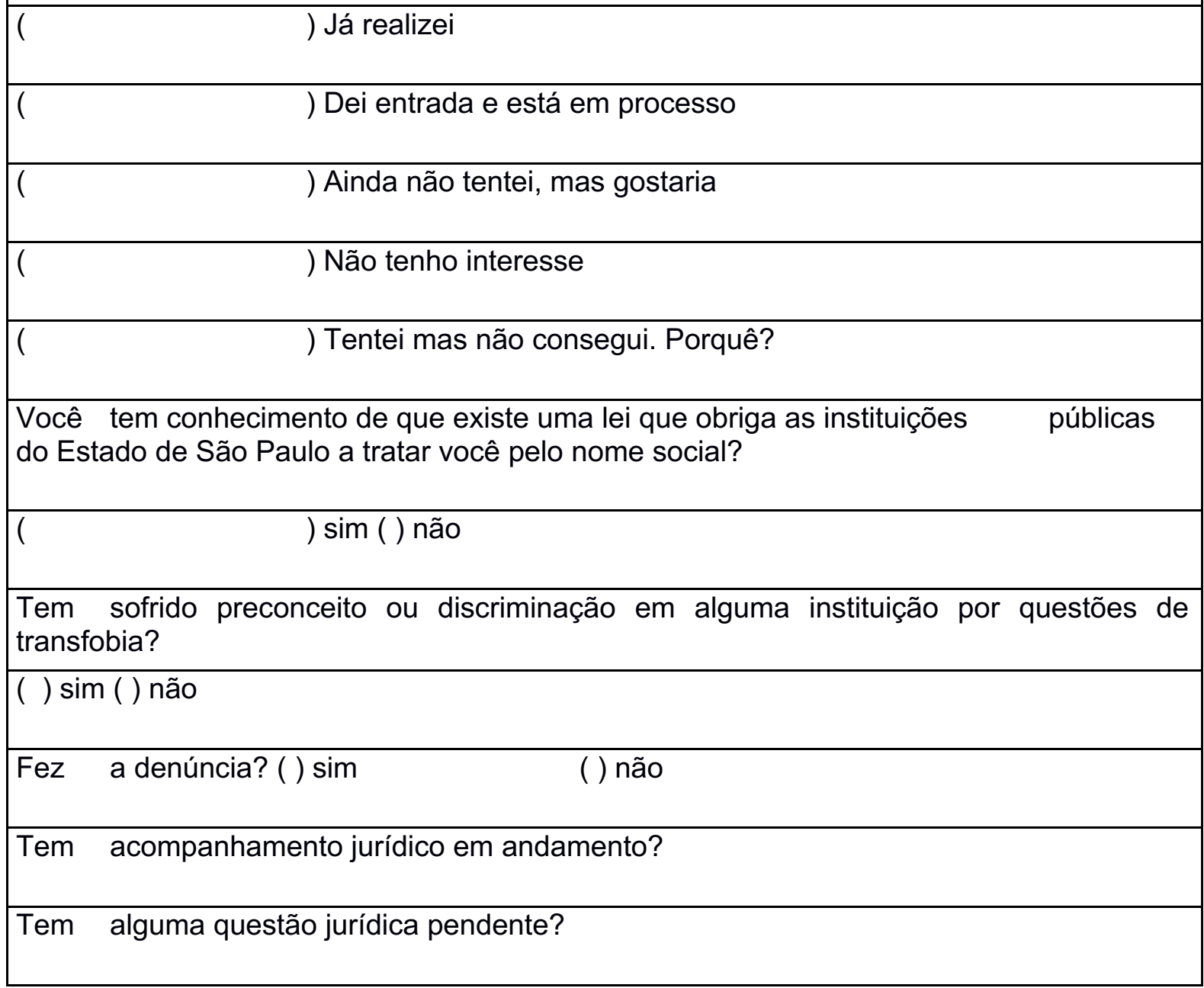

"Agora faremos algumas perguntas que fazem parte de um questionário sobre qualidade de vida. Esse é um questionário que é aplicado sempre da mesma maneira, não leva em conta quem é a pessoa que está respondendo, por isso algumas perguntas podem não fazer sentido para você, mas peço que você tente dar uma resposta para cada uma delas" 


\begin{tabular}{|c|c|}
\hline C.3 & Como você avaliaria sua qualidade de vida? \\
\hline C.4 & Você está satisfeita(o) com a sua saúde? \\
\hline C.5 & O quanto você aproveita a vida? \\
\hline C.6 & Em que medida você acha que a sua vida tem sentido? \\
\hline C.7 & O quanto você consegue se concentrar? \\
\hline C.8 & Você é capaz de aceitar sua aparência física? \\
\hline C.9 & Você está satisfeita(o) consigo mesmo? \\
\hline C.10 & $\begin{array}{l}\text { Com que freqüência você tem sentimentos negativos tais como mau humor, } \\
\text { desespero, ansiedade, depressão? }\end{array}$ \\
\hline C.11 & $\begin{array}{l}\text { Quão satisfeita(o) você está com suas relações pessoais (amigos, } \\
\text { parentes,conhecidos, colegas)? }\end{array}$ \\
\hline C.12 & $\begin{array}{l}\text { Quão satisfeita(o) você está com o apoio que você recebe de seus } \\
\text { amigos? }\end{array}$ \\
\hline
\end{tabular}

PARTE 2: PROCESSO DE EVOLUÇÃO E CONSTRUÇÃO DE METAS

QUAL(AIS) A(S) MAIOR(ES) DIFICULDADE(S) ENCONTRADA(S) PARA REALIZAR SEUS PROJETOS?

ENTRE AS DIFICULDADES, QUAL VOCÊ CLASSIFICARIA COMO A DE MAIOR IMPACTO PARA SI PRÓPRIO?

QUAL SUA DISPOSIÇÃO PARA INICIAR UM PLANO DE AÇÃO PARA UM PROJETO DE VIDA?

PLANEJAMENTOS DOS ATENDIMENTOS

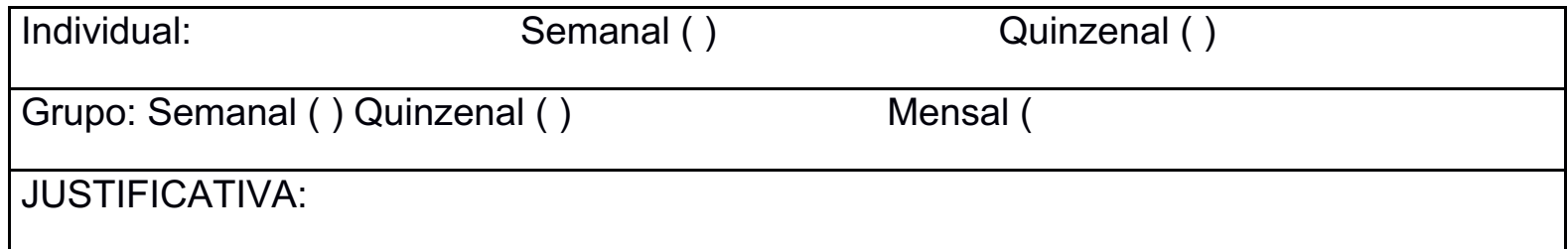

ASSINATURAS:

Pedagogo Psicólogo

Assistente Social Advogado 